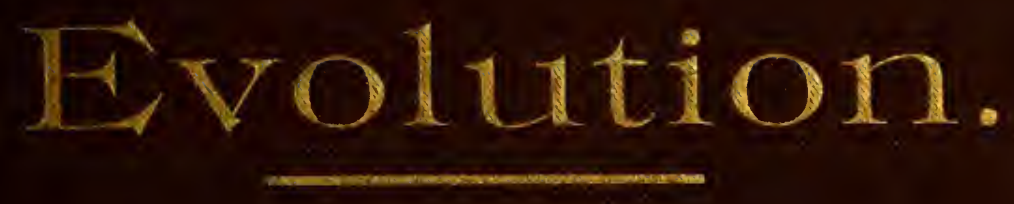


mOICGY LIBRARY

1llillitidy 016.575 filmavut

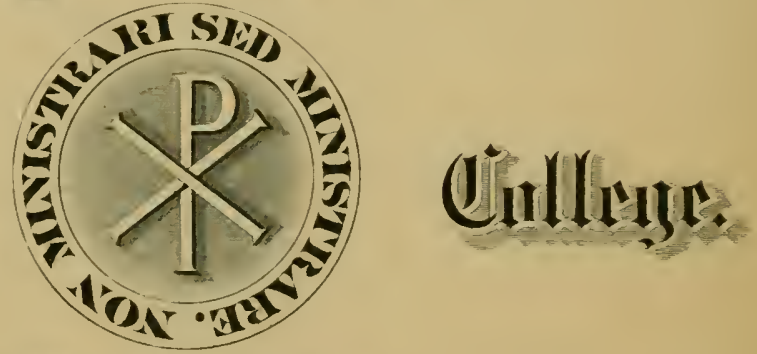

N:39544

$$
\text { Hiramenten ling }
$$

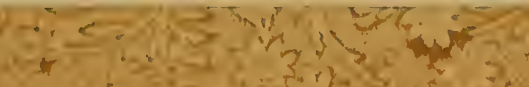




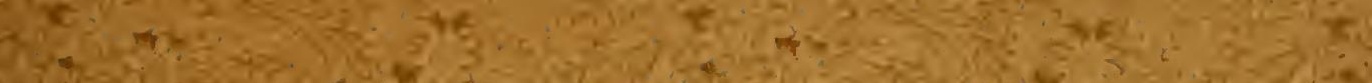

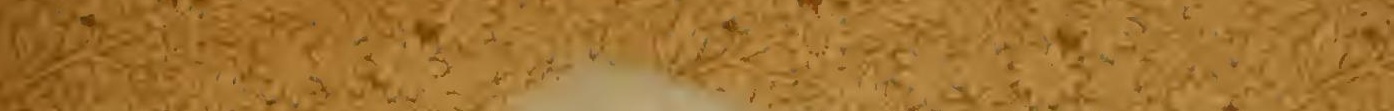

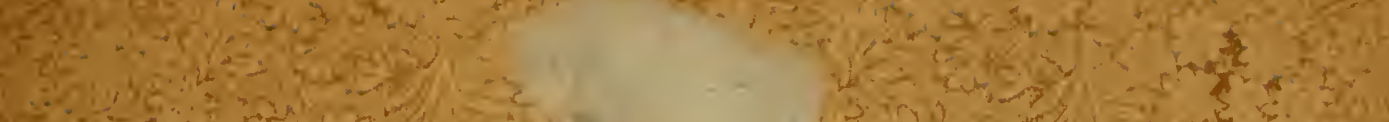
whing

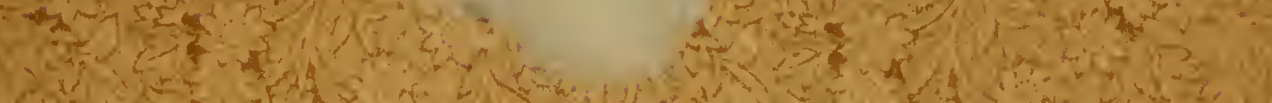

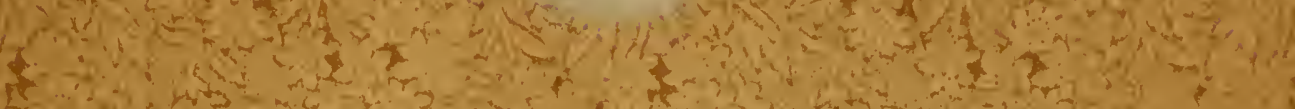

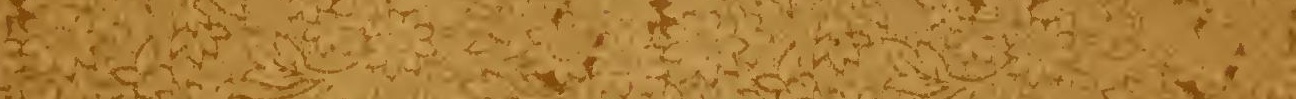

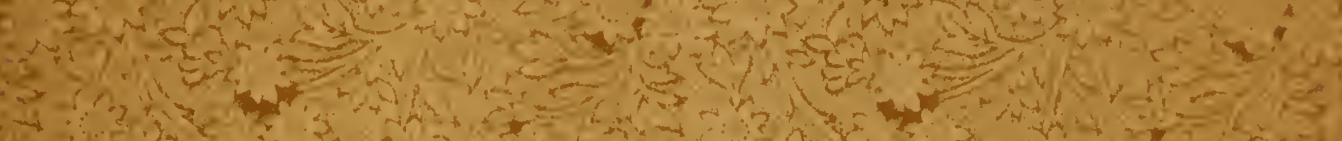

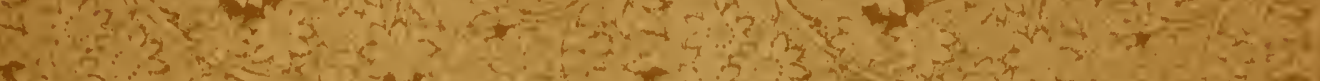

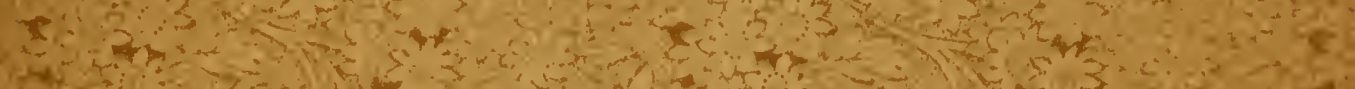

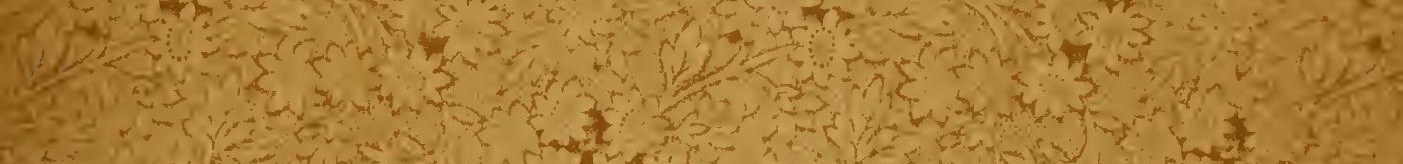

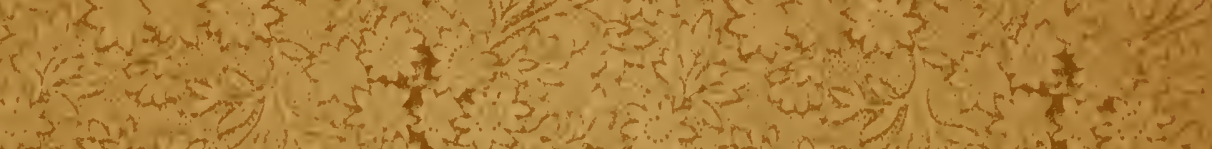
- 5 ह

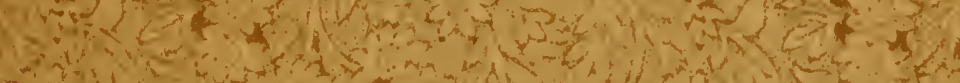
1
3

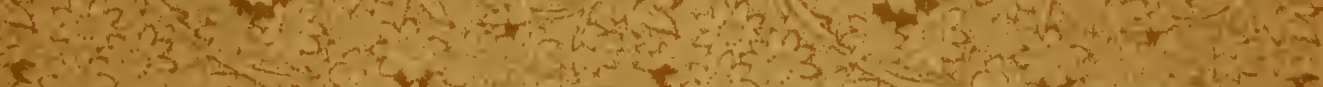

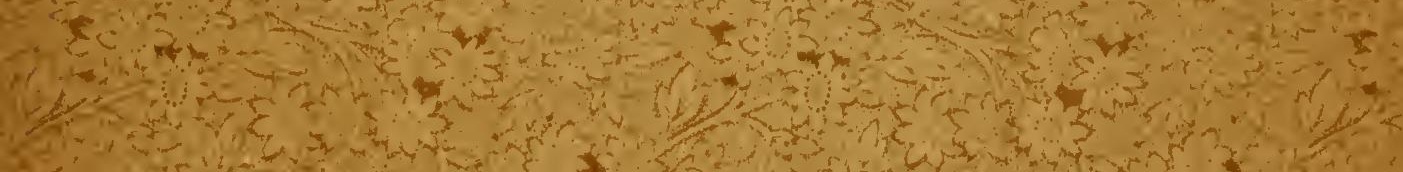
(5)

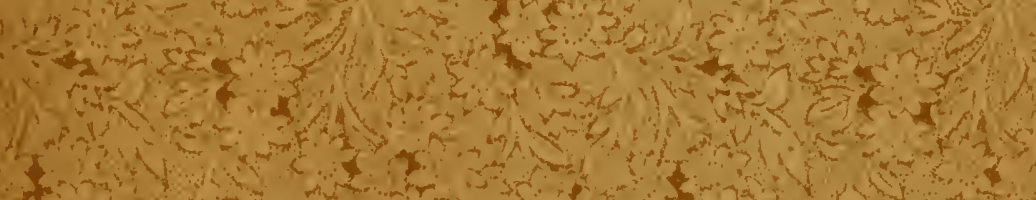

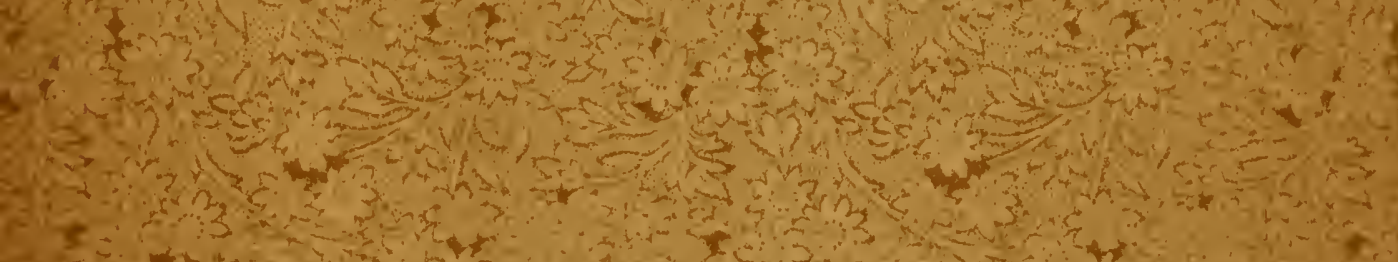

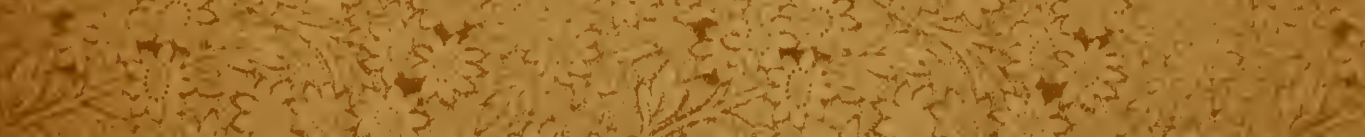

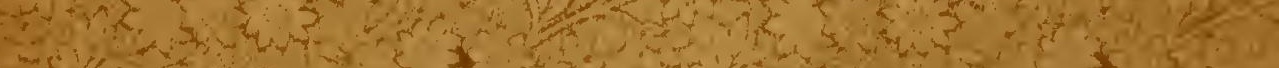

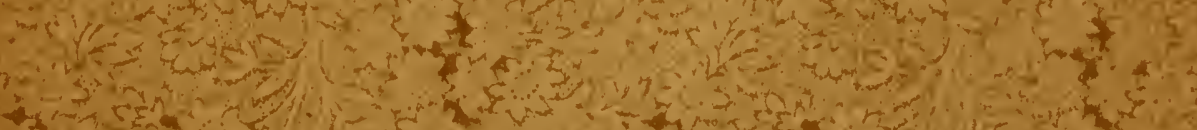

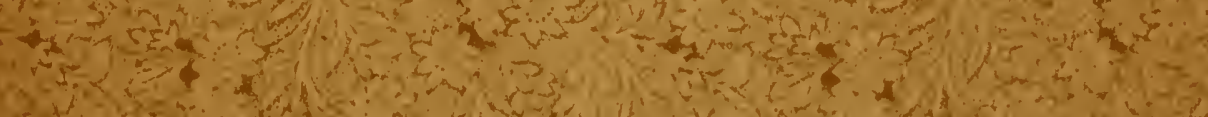

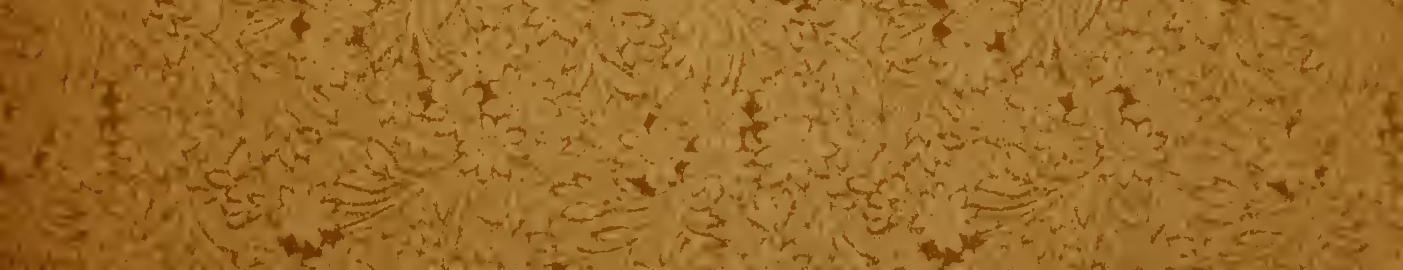



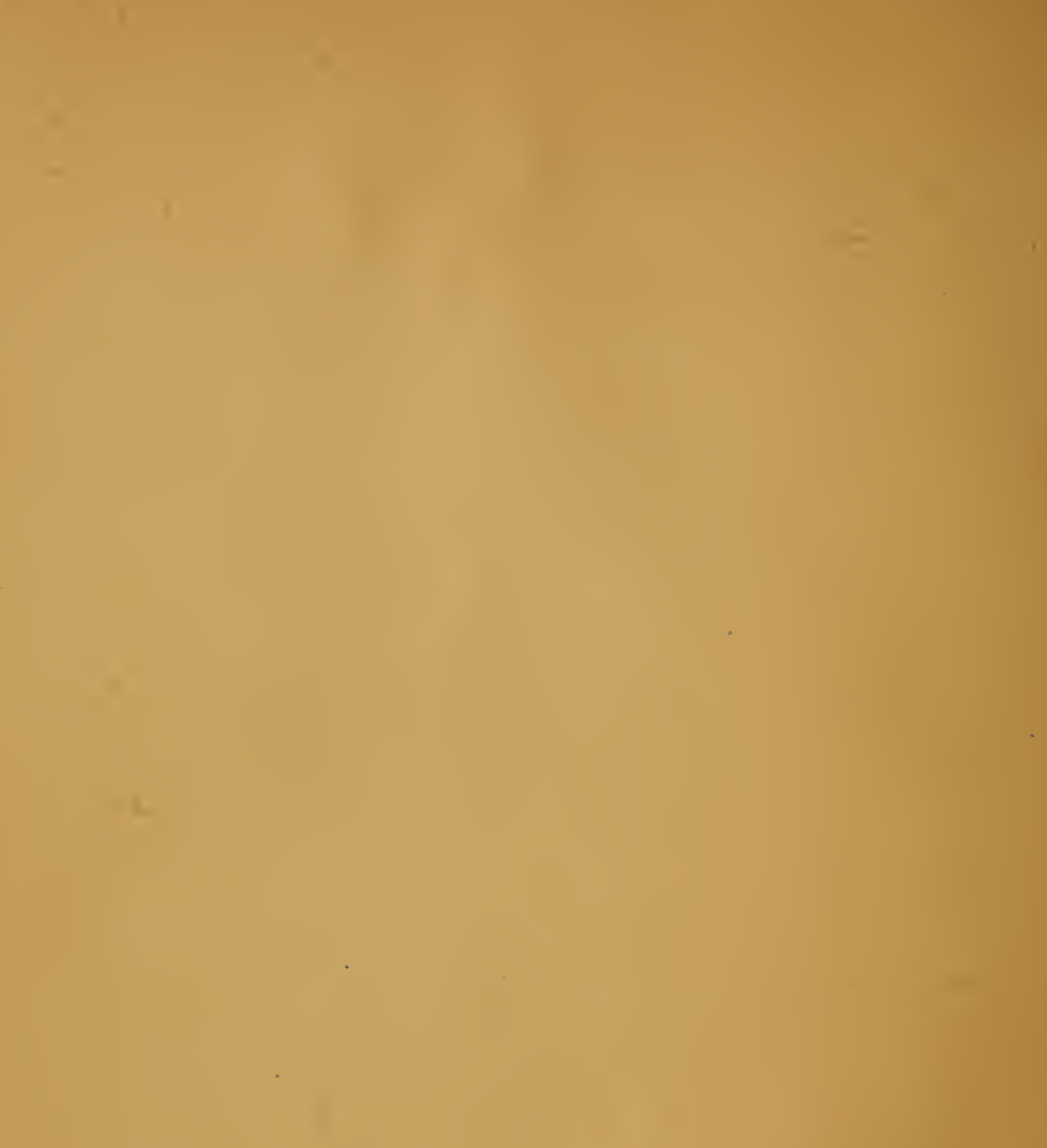




\section{Speeimen Press Notices of "Evolution."}

"A look which serves a (louhle purpose: to present, succintly yet completely, the evolution philosopliy: and to slow its application to and influence upon all the interests of life. It is not possible to speak of this book with any degree of reserve. It is entirely admirable. It should lie a matter of pride to every American that such an arlequate presentation of a vital principle lias been made on this side of the Atlantic."-Buston T'imes.

"Devoted to concise and remarkably clear expositions of evolntion as a philosophy, as relating to the physical world, to man, to society, to theology, to morals, and religious thonght. The book is prefaced by two extremely interesting biographical chapters."-C'ambrielge (.Muss.) Tribune.

"The subjects are very fully (liscussed, and the seeker for information can scarcely find the case of the evolutionists letter stated in a popular form. This combination of thonght and study in one inexpensive volmme is simely and valuable." $-N e x$ " Bedford Mercury.

"The whole field of Evolution is presented in a popular manner, in a handsomely printed book,... one of the clearest and most comprehensive on the subject that has yet appeared. It will prove most acceptable to the general reader." - 'incimmiti Commercial Gazette.

"The writers seem to have taken pains to make their subjects plain, and to have had good success in doing so. We recommend this collection of essays to those who wish for a simple but accurate exposition of the evolutionary philosophy." -Scienee (New York).

"One of the best thoronghly popular works on the general subject that have yet appeared."-Pullic Opinion.

"An admirable contribution of thought upon this problem,- one of the most complete yet made,-and will be found of interest to everylıody."-Lawenee Ameriean.

"The subjects are all broadly treated, and, taken together, these essays comprise a clear and concise presentation of the theory of evolution."-Boston Burlyet.

"Scholarly and instructive."-New" York Sun.

“These essays present the doctrine of Evolution in almost every aspect, and a glance at the list of anthors will sufficiently indicate the admirable skill and thought that have been bronght to bear upon the subject in this edifying volume. The book merits hearty commendation."-Boston Suturlay Eirening Gazette.

"They are, without exception, excellent in thought, spirit and method of treatment."-Truth. (Pittslur(yh).

"lt is most comprehensive, yet popular, in its mode of treating its subjects, and furnishes in compact form the last words which have yet appeared om the subjects of which it treats." - New Huren Pulludium.

"The value of the look cannot he overestimater, for it is representative of the foremost thought on the foremost theory of the age." -Buffalo Conrier.

"Every essay in the work recognizes evolntion as a universal law. It is made to account for all the phenomena of the universe, and to us it appears to account for them remarkably well. We confess, with something of chagrin, that we can discover nothing atleistic, immoral or heterodox in their peculiar opinions. We had buckled on our almol, and set our controversial lance in rest, in preparation for a tilt with this adventurous knight-errant, Evolution. But we lecline to enter the lists; for is not the mailed warrior whom we mistook for an enemy the mightiest champion of truth? . . The book is handsomely printed, substantially bound, and fully indexed." - Lou'ell Times.

"The book is one that will find a welcome among advanced thinkers."-Philudelphia Times.

"A work of musual interest-a hook to set thinkers to thinking." - Troy Times.

"The volume is one which every man who wishes to keep a c courant with the latest phases of thought, but has not the leisure to master elaborate treatises, should welcone... The lectures are popular in the sense that they do not require on the part of the reacler any special scientific preparation, but they are not popnlar in the sense usually attached to the plirase, 'popular lectures,' - that of a weak dilution of thought and knowledge to meet the capacity of weak intelligences. . . Each lecture is followed by an abstract of the discussion which the lecture evolved, and the dissentient reader may often have the satisfaction of finding his own criticisms pertimently stated." -IIome Journal (New York).

"The drift of the volume altogether is in the direction of intellectual expansion." - New York Tribune.

"It is a systematic, concise, and comprehensive presentation, and should be read by all interested in the sulject whether from a hiological, sociolngical, or philosophical standpoint."-Popular sciance Ifors. 


\section{JAMES H. WEST, Publisher, Boston.}

\section{COMMENTS FROM PRIVATE SCIENTIFIC SOURCES.}

"It is a book not to be liyhtly passed over,-inalicating almost a new epoch in the evolution propayunda."

"The book is $A$ BOOK. It is unique. I do not believe there is any other such book, nor that there will be. It will nuicersally take. Only afew glances at it are required, and then the expressions of rastonishment and interest follow.",

[From HERBERT SPEXCER.]

"The mode of presentation seems to me admirably adapted for popularizing Evolution views."

[From Johs Fisíe.]

"I think your schedule attractive and valuable."

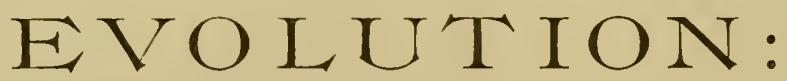

Popular Lectures and Discussions before the Brooklyn Ethical Association.

"A collection of essays, exhibiting the roctrine of Evolution as applied to religious, scientitic and social matters, ly well-read and cultivated gentlemen. Scholarly and instruetive ; we commend the book." - New York Sum.

"Among all these papers there is not one that is weak, commonplace or uninteresting. They are all full of thought, presented in clear language, and in an admirable spirit."-lieligio-Philosophical Journal.

"Extremely entertaining and instructive, ... the book is especially intended to spread a knowledge of the views of the masters of the Evolution theory, making a smooth, even path for the ordinary mind to move forward on, so that the general comprehension of the subject may be made easy." Brooklyn Citizen.

OUTLINE OF CONTENTS :

Herlyert Spencer : His life, writings, and philosophy.

Daniel Greenleaf 'Thompson.

Charles Rohert Darwin : His life, works, and influence.

Rev. John W. Chadwick.

Solar and Planetary Evolution How suns and worlds come into leing.

Evolution of the Earth : The story of geology.

Garrott I'. Serviss.

Evolution of Vegetal Life: How life begins.

Dr. Lewis (צ. Janes.

Evolution of Animal Life :

William Potts.

The Deseent of Man: His origin, antiouity, growth.

Rossiter W. Raymonu, Ph.D.

Evolution of Mind: Its nature, and development.

E. I). Cope, Ph.D.

Fvolution of Society : Families, tribes, states, classes.

Dr. Rolsert (x. Eeeles. Evolution of Theology : Development of religious beliefs. Z. Sicluey Sampson. Evolution of Morals : Egoism, altruism, utilitarianism, etc.

Dr. Lewis G. Janes. l'roofs of Evolution : The eight main seientific arguments. Nelson C. Parshall. Evolution as Related to Religious Thought. Rev. John W. Chadwick. The Philosophy of Evolution: Its relation to prevailing systems.

Starr II. Nichols. The Efrects of Evolution on the Coming Civilization. Rev. Minot J. Savage.

ONE VOLUME, Fine Cloth, 408 Pages. ILLUSTRATED. Complete Index. \$2.00, postpaid. 


\section{JAMES H. WEST, Publisher, Boston.}

\section{EVOLUTION ESSAYS, --- SECOND SERIES.}

"Deserve the attention of readers of popular science. They include, so far, excellent lectures."-Literury World.

"One of the most systematic, concise, and comprehensive presentations in popular form of the foundation and theory of evolution. Excellent,... succint, . . interesting." - Public Opinion.

\section{SOCIOLOGY:}

Popular Lectures and Discussions before the BrooklyN Ethical Association.

The Scope and Principles of the Evolution Philosophy, The Relativity of Knowledge, Primitive Man,

Growth of the Marriage Relation, Evolution of the State,

Evolution of Iaw,

Evolution of Medical Science,

Evolution of Arms and Armor,

Evolution of the Mechanic Arts,

Evolution of the Wages System, Education as a Factor in Civilization,

Evolution and Social Reform: 1. The Theological Method,

Rev. John W. Chadwick.

Evolution and Social Reform: 2. The Socialistic Method,

Evolution and Social Reform: 3. The Anarchistic Method,

Evolution and Social Reform: 4. The Scientific Method,

Hugh O. Pentecost.
Dr. Lewis G. Janes. Dr. Robert G. Eccles.

Z. Sidney Sampson.

C. Staniland Wake.

John A. Taylor.

Prof. Rufus Sheldon.

Dr. Robert G. Eccles.

Rev. John C. Kimball.

James A. Skilton.

Prof. George Gunton. Miss Caroline B. Le Row.
Asa Gray,

Edward Livingston Youmans,

Daniel Greenleaf Thompson.

Mrs. Mary Treat.

Prof. John Fiske.

Any of the above Essays sent, postpaid, on receipt of price.

EACH NUMBER, TEN CENTS.

\section{PUBLISHER'S ANNOUNCEMENT.}

In response to a demand for the above Sociological Essays in a bound rolume, uniform with "Evolution," the Seventeen Lectures above enumerated will be at once reprinted, with Complete Index, finely bound in cloth. Pages, 408; price, postpaid, \$2.00. (The two volumes, "Evolction" and "Sociologr," to one address, postpaid, \$3.50.)

Address Janes H. West, Publisher, 196 Summer Street, BOSTON. 


\section{EVOLU'T I ON.}

THIRL THOLSANU. 18 go. 


\section{EVOLUTION}

Popular Lectures and Discussions BEFORE THE

Brooklyn Ethical Association.

BOSTON :

JAMES H. WEST, PUBlisher

192 SUMMER StreET 1889 
¿ 1 i $4: \ldots$

COPYRIGHT, 1889 ,

AS INDIVIDUAL LECTURES.

See foot-note first page of each essay.

\section{SCIENCE}

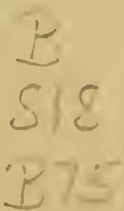




\section{PREFACE.}

Evolutios: The word is in every mouth. A vague, often an incorrect conception of its meaning in the field of biology and with reference to the origin of Man, has reached the popular mind, and stirred it to further investigation and inquiry. Even in its biological aspects, the doctrine of Evolution is seen to touch the great problems of religion and philosophy - of origin and destiny. But it is begimning to be understood that not alone as an explanation of the method whereby living forms have been produced and developed is this doctrine alive with human interest and pregnant with important influences upon human thought and human welfare. Evolution, reaching backward, takes hold upon the great cosmic problems of the birth and growth of worlds, the nature of Matter and Spirit, the relation of the phenomenal Universe to its efficient Cause. Reaching forward, it touches and illuminates the pressing problems of ethics and sociology, offering to the careful student wise instruction for his guidance in all the practical affairs of life.

Evolution, it is said, is not a philosophy, it is not a religion"it is only a method." But it is a universal method ; the discovery and formulation of its law as applied to all the processes of inorganic, organic, social and intellectual development, constitutes the widest generalization of science. It cannot be otherwise, therefore, than that its acceptance should necessitate a reconsideration of the fundamental problems of philosophy and religion, as well as a reconstruction of our notions in regard to the permanence of species and the origin of human life. As tersely defined by Professor Le Conte, "Evolution is continuous, progressive change, according to certain laws, and by means of resident forces." In the place of miracle it posits law ; instead of creation ex nihilo, it affirms an orderly development resulting from the action of eternally-existent forces ; for the old conception of a mechanical universe set in motion by a non-resident Creator, it substitutes that of a vital universe, the "resident forces" of which are symbols of a Power that is at once immanent and transcendent,- revealed in all its relations to our human consciousness, but by the very 
nature of that consciousness forever unknown in its ultimate essence.

Universal in its scope, penetrating every region of thought and life, it appeared to the managers of the Brooklyn Ethical Association Lectures that no work could be of more general and vital interest than that of popularizing correct views of the Evolution philosophy. An advance copy of our programme sent to Mr. Herbert Spencer, elicited from him a letter of cordial commendation,* in which he affirmed that "The mode of presentation described seems to me admirably adapted for popularizing evolution views," and expressed a hope that the lectures might be widely circulated in printed form. Efforts in this direction were subsequently undertaken. The preparation of these lectures has been a labor of love, and for the most part gratuitous on the part of their authors. As separately published, they have already been profitably used by numerous societies and individuals engaged in this study, and it is hoped that they may have a yet wider circulation in the form in which they are now offered to the public. The chief hope and desire of the Ethical Association, and of the authors of these lectures, will not be met, however, unless they stimulate thought beyond their mere perusal, and prepare many minds for the systematic reading of the more complete expositions of the Evolution philosophy in the works of Spencer, Fiske, Darwin, Haeckel, Wallace, Huxley, Tyndall, Cope, and other recognized authorities. Not merely to satisfy, but to create hunger for truth is the object of these lectures. The subject is too vast to be treated completely in a single volume. We are aware of imperfections - yet we trust that the lectures will serve the purpose for which they are intenderl, and thus justify the labor and devotion of those who have participated in their production and publication. 


\section{CONTENTS.}

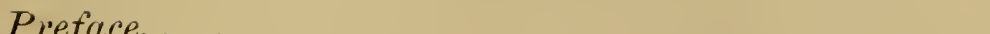

iii

Herbert Spencer, . . . . . . . . . . . . 3

His life and personal characteristics ; his views on education ; his religious opinions ; his earlier writings ; the relation of his work to Darwinism and the evolution philosophy.

By Daniel Greenleaf Thompson.

Charles Robert Dartin, . . . . . . . . 25

His ancestry, life, and personal characteristics; the voyage of the Beagle; discovery of natural selection; the two factors of the Darwinian theory; Darwin and Wallace; Louis Agassiz and evolution; influence of Darwin's studies on his religions opinions. Evolution before Darwin ; views of Goethe and Lamarck.

By Rev. John W. Chadwick.

Solar and Planetary Evolution,

How suns and worlds come into being; the nebular liypothesis of Laplace and Faye ; Creation or Evolution? Did the material universe ever have a beginning?

By Garrett P. Serviss.

Evolution of the Earth, .

The story of geology; how the world grew ; the order of stratification ; the action of fire and water ; preparation of the earth for vegetable and animal life.

By Dr. Lewis G. Jaxes.

Evolution of Vegetal Life,

How does life begin? The problem of spontaneous generation; morphology - the forms of leaves and flowers; the geographical distribution of plants ; methods of fertilization; distinctions and likenesses between plants and animals.

By Williay Potts. 
Erolution of Animal Life,

The evidences from geology, geographical distribution and comparative zoology; the problem of special creation; the laws of evolution ; Darwinism as modified by Romanes; the mutability of species; the order of zoological evolution.

By Rossiter W. Raymond,Ph.I).

The Descent of Man,

Relation of man to the brute creation; his ancestral line; duration of human life on the planet; growtl of mind, reason, and the moral sense ; consciousness as a factor in human evolution.

By Edward D. Cope,Yh.D.

Evolution of Mind,

The mind and the nervous system ; the nature of mind ; correspondence of life and mind ; the growth of consciousness; nature and evolution of intelligence; instinct, memory, reason, feelings, will.

By Dr. Robert G. Eccles.

Evolution of Societr, 203

Primitive man; growth of the family, tribe, city and State ; development of the domestic relations ; marriage ; ceremonial and political institutions; is society an organism?

By Janes A. Skilton.

Evolution of Theologr,

233

Origin of religious beliefs; ideas of primitive man; animism, and ancestor-worship; growth of natureworship and idolatry; polytheism, monotheism and pantheism; the doctrine of the Absolute.

By Z. SIDNEY SAMPSON.

Evolution of Morals,

How altruism grows out of egoism ; the proper balance ; characteristics and relative value of ethical systems; utilitarianism, rational and empirical; influence of the evolutionary theory of morals on ethical sanctions.

By Dr. Lewis G. Janes.

Proofs of Evolution,

a, from geology ; b, from morphology ; c, from embryology ; d, from metamorplosis ; e, from rudimentary 
organs ; f, from geographical distribution; g, from discovered links; $h$, from artificial breeding ; $i$, from reversion; $\mathrm{k}$, from mimicry.

By Nelson C. Paishall.

Erolution as Related to Religious Thought, 319

The doctrine of the unknowable; special creation as related to Darwinism; Spencer's reconciliation of religion and science; the doctrine of design ; law and miracle.

By Rev. Johy W. CHADwick.

The Philosophy of Evolution, . . . . . . 343

Relation of the doctrine to prevailing philosophical systems; metaphysics and the scientific method; materialism and the evolution philosophy; realism and idealism; beneficent results of the prevalence of materialism on human progress.

By Stairi H. Nichols.

The Effects of Evolution on the Coming CivilizAtion, . . . . . . . . . . . . 369

Plans for social regeneration as tested by evolution; Communism, Nationalism, and Socialism; probable influence of the evolution philosophy in the settlement of social and economic problems.

By Rev. Minot J. Savage.

Index, . . . . . . . . . . . • • • • . 393 
The eye reads omens where it goes, And speaks all languages the rose; And, striving to be man, the worm Mounts through all the spires of form.

-Nature, $i ., 7$.

THE fossil strata show us that Nature began with rudimental forms, and rose to the more complex as fast as the earth was fit for their dwelling-place; and that the lower perish as the higher appear. Very few of our race can be said to be yet finished men. We still carry sticking to us some remains of the preceding inferior quadruped organization. . . The age of the quadruped is to go out, - the age of the brain and of the heart is to come in. And if one shall read the future of the race hinted in the organic effort of Nature to mount and meliorate, and the corresponding impulse to the Better in the human being, we shall dare affirm that there is nothing he will not overcome and convert, until at last culture shall absorb the chaos and gehenna. He will convert the Furies into. Iuses and the hells into benefit.-Culture. 


\section{HERBERT SPENCER}

BY

DANIEL GREENLEAF THOMPSON

Althor of "A Srstey OF Psychologr," "The Probley of Evil," "Tile. Religiocs Sextivexts of THE HUMA MIXD," ETC. 


\section{COLLATERAL READINGS SUGGESTED}

\section{IN CONNECTION WITII ESSAY I.}

Biographical Sketch of Herbert Spencer, by Professor E. L. Youmans (in Popular Science Monthly, March, 1876); Essays on Spencer, in Popular Science Monthly, November, 187t, and North American Review, October, 1879, by Professor Youmans; Spencer's Reconciliation of Reliyion and Science, by Professor Youmans (in Christian Examiner, May, 1862) ; Spencer's Education, Study of Socrology, Essays, and Recent Discussions. 


\section{HERBERT SPENCER.*}

As THE world grows older it knows more about its greatest men and finds them out quicker; but in order to be noticed it is necessary for them to be greater than in former times. The idea that men of long ago were of superior mould and larger intellectual stature than those of to-day is a false one, though useful, no doubt, to sustain the doctrine of a lapse from an originally perfect state. Those sentiments which have given rise to and supported the theory of monarchical sovereignty made demigods of military chieftains, of kings and emperors, and endowed them, in the minds of people generally, with all the virtues which they did not possess but which seemed to be necessary to a properly equipped great man. The same method has pervaded the world of study and of letters. Plato and Aristotle have been esteemed much greater men than any of our degenerate times, and there has been, and still is, a mystical value attached to their least words.

Without disparaging these really worthy Greeks, who would be considered good philosophers, as philosophers go in our time, and who, it must be remembered, were far better than they used to run in earlier days, I do not hesitate to aver that the subject of this sketch, for instance, is much greater than either of them. Nor would I say it of him alone, but also of many others, who are not as prominent. The general level of intellectual power is so far raised in modern times that it is exceedingly difficult for any one man to become pre-eminent among his fellows. His limitations are more accurately measured, his weaknesses are detected, and he has none of the divine halo about his head that used to awe people into adoration and out of criticism. Believe me, the modern way is the best. These are more fortunate times, when we see Carlyle's "Great Man" certainly disappearing from the earth and soon to share the fate of the mastodon and the mammoth. True greatness

* Copyright, by D. G. Thompson, 1888. 
will be a natural, not a supernatural, greatness. Those below will be raised up, and the model man of the future will be he who walks modestly among his fellows, claiming nothing and needing to claim nothing, because his intellect, his character, his deeds shine in their true light, neither obscured nor artificially heightened. And of such there will be many.

It is still hard for merit to obtain recognition; but if a man does good work, and chances to live in one of the most enlightened countries of the world, he will probably be found out before he dies. Mr. Spencer had a long struggle before much attention was paid to him, but at length his reward came. One great difficulty in his case was the lack of a thorough academical education. By no means the least of the advantages of a collegiate or university course is that the student is admitted into a society of scholars, who will form the intellectual aristocracy of their generation. He who joins them becomes known to the others, is established as a member of the guild, and wears his badge to the end of life. Both recognition and honor come to him more easily, by virtue of his membership, to say nothing of the advantages of the courses of study and discipline in themselves. At the age of thirteen Herbert Spencer went. to live with his uncle, the Rev. Thomas Spencer, Rector of Hinton, who was a graduate of Cambridge. The uncle wished Herbert to prepare for the university, but the latter was obstinate and refused. Prof. Youmans remarks that the uncle lived to acknowledge that Herbert probably took the right view of the matter. I do not think he did. $\mathrm{Mr}$. Spencer's thonghts and writings seem to me to show their main deficiency in precisely those things which a university training would have supplied. Many of his friends, however, - it is fair to state, - believe that a university training was incompatible with the traits on which the development of his philosophy depended.

Herbert Spencer was born in Derby, April 27, 1820. His father and grandfather were teachers, and Herbert, at three year's of age, was the only surviving child. He did not learn to read until seven. He was delicate in health, and was not pressed. When he did go to school, he was not brilliant. Prof. Youmans says of him that "he was characterized as backward in things requiring memory and recitation, but as in advance of the rest in intelligence." $\mathrm{He}$ 
never got along well with languages, but was excellent in geometry, in physics, and in drawing, both mechanical and free-hand. At the age of sixteen he taught school for three months, with good success. Immediately after this, he entered upon a year's engagement under Sir Charles Fox, then engineer for the construction of the London and Birmingham Railway. 'This was succeeded by eighteen months' similar service in connection with the Birmingham and Gloucester Railway. From 1841 to 1850 he was occupied with private studies; now and then with engineering engagements, to some extent upon mechanical inventions, in one or two political movements, in the writing and publication of various papers, and finally as sub-editor of the Economist. In 1850 he published "Social Statics," his first important work, but one with which he was so much dissatisfied afterward that he tried to suppress it.

From 1850 to 1855 , a number of essays were completed, — "The Theory of Population," "The Development Hypothesis," "Over-Legislation," "The Universal Postulate," and others. In 1855 the "Principles of Psychology" was finished, and it was in the writing of this that the anthor arrived at the conviction that the law of evolution was universal in its applications. The labor of preparing the Psychology, carried on without due attention to hygienic rules as to diet and exercise, was sufficient to break down his health. His nervous system was so disordered that he could do no work for eighteen months. This, however, did not prevent his active mind from elaborating a scheme which grew more definite day by day. He came to believe that the law of evolution should be made the basis of philosophy, and to devise the plan of a system established thereon. As his health improved, he prepared to devote his entire life to such a work, and in 1860 he published the prospectus of his philosophical system, as we have it to-day, laying out a task of twenty years, which ill-health has prolonged to the present time and which is still unfinished.

If to what has been said we add that Mr. Spencer, while engaged in his great work, has lived a quiet life in London, with occasional vacations, often on account of illness, during one of which he made a trip to Egypt and during another a royage to America, we shall have substantially his biography - the uneventful existence of a student who saw what was in him to do, planned his course, and fol. 
lowed it steadily to the exclusion of everything else. 'The history of his personal life may be told in a paragraph; but who shall write the history of his books? Who can measure the influence they have already exercised ubon human thought and action, and who will venture to predict the limit of their power?

It is not to be wondered at, perhaps, that social advancement involves antagonisms, since the whole process of evoition throughout nature is one of action and resistance. This is a law of social as well as physical existence. But. it does seem a little remarkable that, where antagonism occurs, the interest of men is aroused in proportion to its violence. They are a great deal more observant of destruction than of constructive results. The lightning and thunder command attention, while the sun which is the life of all, sustaining all things, and upon which evolution for our planet is dependent, is scarcely considered. The "warlord," who distinguishes himself by killing his fellows, and shows prowess in battle, is the prominent figure in what is called history, while he who has moulded the opinions and conduct of men occupies an inferior position. Even in the life of a scholar like Mr. Spencer, it is his collisions with other people, prominent representatives of other schools, that make his reputation more than the still, silent work which is accomplished by the diffusion of the know redge contained in his books, - though it extend from London to San Francisco, and in the other direction to the interior of Siberia, where George Kennan found copies of his writings, somewhat mutilated, indeed, by the Russian censor. But the power which secures the world's progress is assimilative, and, though conflict may be necessary to prepare the way, it is the silent and peaceful forces which, after all, convert the nations. The influence of the great philosopher, though he be not a conspicuous figure of the political or social life of his age, is pervasive, stimulating to activity, far-reaching in time, and works powerfully and effectively even where we are not able to trace it.

Mr. Spencer's writings met with neglect, and then condemnation. His systematis treatises were published at his own expense, and the original plan adopted was of a serial issued to subscribers. The publications did not pay, and their author was discouraged by the fact that they were 
eating up his substance and bringing in nothing. The most important impulse toward success was given to them by our own countryman, Prof. Edward L. Youmans, who, as an English friend said to me, really discovered Spencer. This discovery was accomplished, as Prof. Youmans himself tells us, through reading the "Principles of Psychology." Of this, even he could make nothing at first, and he threw it aside with some impatience. But his sister, Miss Eliza A. Youmans, took up the discarded volume, read it with care, and told her brother that it was a new revelation in philosophy. In truth, then, we ought to say it was Miss Youmans who discovered Spencer. Her brother, however, soon. came to realize the importance of the discovery, and did quite enough to vindicate his claim to a partner's share of the credit. He interested himself practically in promoting the circulation of Mr. Spencer's works. The Messrs. Appleton, through his efforts, took up their publication, and for the first time a character and standing were given to them, in some degree commensurate with their importance.

Little by little recognition came, until by-and-by it dawned upon the thinking world that Herbert Spencer was the foremost philosopher of his day. It is gratifying to know that, after a while, his books began to yield him an income (though by no means a large one), and this is the case at the present time.*

Nir. Spencer is a bachelor. Evidently he has had no time to get married. He was not, however, a recluse, till obliged to be by the exigences of his work and the necessity of caring for his health. In 1879 I missed the pleasure of meeting him at a dinner party, because, as he wrote, he had engaged to take two ladies to the opera that evening. Observe that he took two ladies; he knew how to protect himself; it is a mistake to suppose that philosophers are never practical! He has always entered into social life as

* It is a mistake to suppose that Mr. Spencer was ever in a condition of porerty. He saw, however, that his expenditures for the publication of his works would necessarily soon exhaust his means, and was distressed, not on account of immediate wants, but with the prospect of having to abandon his cherished undertaking. The exact circumstances of the rendering of American assistance for the completion of his works were set forth in a letter written by Prof. Youmans to the New York Tribune, in June, 1872. About $\$ 7000$ was raised by American friends for this purpose. The amount was accepted by Mr. Spencer, "as a trust to be used for public ends," and was employed chiefly to defray the expenses attendant upon the compilation of the tables of the "Descriptive Sociology." 
much as he could without interfering with his work, and has been a welcome and an agreeable guest in many households.

His most regular associations of this sort have been at the Athenæum Club, which is instituted, in the language of its constitution, "for the association of individuals known for their scientific or literary attainments, artists of eminence in any class of fine arts, and noblemen and gentlemen distinguished as liberal patrons of science, literature or the arts." The Athenæum gives the privileges of its home to such non-residents as its Committee of Invitation may select, for the period of their sojourn in London. If I may be pardoned personal references, it was my good fortune to be honored with this limited membership at one time, and, happening to be writing home to a gentleman who was an editor, I mentioned various items regarding my stay in London, among others my frequenting the Athenæum. 'To offset any possible suggestion to his mind that I spoke of this from motives of vanity, I put in my letter, with the proper quotation-marks and exclamation-point, the jocose remark of an English friend in describing the Club, that it was "composed of distinguished people at home and less-distinguished people from abroad." I think my correspondent must have been of Scotch ancestry: but, whatever may have been his pedigree, my feelings may be imagined when I afterwards saw, in my friend's paper, a paragraph setting forth seriously, and without the quotation-marks and exclamation-point, that "Mr. D. G. Thompson had been elected a member of the Athenæum in London, a Club which is composed of distinguished people at home and less-distinguished people from abroad"!

The Athenæum includes people of all sorts of opinions. Men are there of as wide differences in religion as are exemplified in Cardinal Manning and Frederick Harrison; or in politics as in Lord Salisbury, Earl Selborne and Joseph Chamberlain. It naturally follows, especially when we consider that the membership of the Club is twelve humdred, that social intercourse within its pale lies in groups formed according to affiliations proceeding from sympathies in ideas, or in work. Mr. Spencer's friends are chiefly those in scientific or philosophical pursuits, among whom Huxley and 'Tyndall are the most intimate. It is his usua' habit to visit the Club-house every day about three o'clock. Al- 
though the library and study rooms afford facilities for work he rarely uses them for that purpose, his hours at the Club being devoted to relaxation and recreation. Billiards constitute his favorite amusement, and he generally is found, with his coat off, in the room assigned for that sport, when the visitor sends the hall-boy to seek him. Whether he plays well, or ill, I do not know ; but such men are not apt to make a fáilure of anything they attempt, and it is creditable to be excellent in billiards if one chooses to play the game. Besides, if one is able to win, it is usually a saving of expense !

Mr. Spencer is a ready conversationalist, very accurate and exact in his expressions. As Dr. Hooker once said to Professor Youmans, "He talks like a book." This characteristic does not strike one as pedantry, and is by no means unpleasant, though it puts the interlocutor on his guard respecting carelessness in his own words. He is at home on all topics of current interest, as well as on those specially appertaining to his studies. He is a keen critic, but not censorious, nor does he seem to entertain or cherish animosities. Nevertheless he is very combative; too much so for his own good. He is fond of striking back at his critics, and has more than once turned aside from his work to take notice of strictures upon his views, when there was little utility in so doing. His controversy with Frederick Harrison is a case in point. However interesting this may be to readers, it after all seems a waste of words. The position of neither thinker was made any clearer, nor was either converted by the other. Nor, I presume, was any one else converted by either, while much of Mr. Spencer's supremely valuable time was consumed in preparing the letters. The latter has that genuinely British trait of character which causes a man to stand up for his rights, and to resist what he deems aggression. Prof. Youmans says he was a disobedient boy sometimes, and that he never would stand bullying at school. No more will he stand it in the journals and reviews. His sensitiveness to invasions upon his pelsonality subjected him to sore trials upon his visit to America. Prof. Youmans, however, managed him well, and was a happy mediator between the sick man who wanted to be let alone, and the impatient public anxious to see and hear the philosopher they honored. The interviewer's attempts were disagreeable, persistence in proffered hospi- 
tality on the part of new acquaintances was annoying; but what drove him nearly frantic was the desire of people, in some places manifested, to look at him as they would look at a fine animal at the agricultural fair. The culmination. of this latter outrage was reached, I regret to say, in my native State, - at Burlington, Vermont, the home of Minister Phelps and Senator Edmunds. His arrival having been announced in the daily paper, quite a number of people called to pay their respects, and a little demonstration in his honor was threatened. Mr. Spencer however, tired and ill, had gone to his room, leaving orders that he conld see no one and must not be disturbed. The people would not be appeased, and to his great horror a party of them went. to his door, knocked, and, when it was opened, told him that they had come to see him and see him they would. His traveling companion remonstrated, but they were many and $\mathrm{Mr}$. Spencer had no gun. They took their look and departed, but of conversation they had none. You may force a hor'se to the water, but you cannot make him drink. No wonder that, after this, Mr. Spencer came to entertain a fear respecting the permanency of our institutions, and to remark, concerning our people, "The American has not, I think, a sufficiently quick sense of his own claims, and, at the same time, as a necessary consequence, not a sufficiently quick sense of the claims of others, - for the two traits are organically related. I observe that you tolerate various small interferences and dictations which Englishmen are prone to resist. I am told that the English are remarked on for their tendency to grumble in such cases; and I have no doubt it is true."

"Do you think it worth while," asks the interviewer, "for people to make themselves disagreeable by resenting every trifling aggression? We Americans think it involves too much loss of time and temper, and doesn't pay."

"Exactly," replies Mr. Spencer; "that is what I mean by character. It is this easy-going readiness to permit small trespasses, because it would be troublesome or profitless, or unpopular to resist, which leads to the habit of acquiesence in wrong and the decay of free institutions." *

One time, at the Athenæum club, I was introduced by Mr. Spencer to Mr. Matthew Arnold, in the lunch-room. I

* "Herbert Spencer in America." D. Appleton \& Co. 1883. 
should like to have been at the next table when, perchance, these two gentlemen might have sat down together and discussed America over a cut of roast mutton, a boiled potato, and a spoonful of peas for each, with a mug of stout and no napkin. I would forgive the newspaper reporter all his sins, against me at any rate, if only he could have been there and reported that conversation. Much would have been said that was true, dribtless; much would have been kindly. Nuch, also, would have been "curious"; nor do I imagine it would have been wanting in "distinction." At the very least it would have been "interesting."

I have noticed a remarkable characteristic of many Englishmen, - the readiness with which, at little and unaccustomed things, they fall into that state which is expressed by the word "aghast." It is chiefly with respect to affairs of personal life, in which they behold a difference of manners. Its first symptom is paralysis; then follows reasoning, from their own stupefaction, subjectively. Because the effect on them is great they magnify the cause. I meet my friend the Englishman one fine day in summer, and say to him, cheerily, "Very warm to-day. A good day for your annual bath." Straightway he is struck "aghast"; and thus he communes with himself: "Yes, quite so; but that is a very extraordinary expression; warm - yes; bath, yes, I know; but annucl bath; what can he mean? He cannot think I bathe but once a year: he has seen the bath-tub which I always carry with my luggage. He had a kindly and genial smile when he said it. I really am not prepared to believe he meant to insult me. But how curious! I have it! It must be that there are many Americans who bathe only once a year. But, if so, how can they keep clean? It is very, very extraordinary. The Americans are a remarkable people; but their manner of address seems to me to be rather infelicitous, don't you know. And they have not yet learned how to live; if they had they would not postpone their bath so long. No, the Americans may have done measurably well in solving the political problem, but it must be allowed on all hands that they have not solved the human problem."

Mr. Spencer, however, is very different from the Englishman of the previous paragraph. He is far too thorough an observer to let his judgment of real conditions be determined by minor and adventitious circumstances. $\mathrm{He}$ is by 
no means an obtuse or narrow man. His opinions respecting America were much more correct and substantial than those of Mir. Matthew Arnold. 'The latter never could get below the surface. His mind was critical, but not synthetic or constructive. With him, manners made the man; and there were no manners save his own. He was lacking in "lucidity." But Mr. Spencer's vision was wide, and his insight keen. He saw things in their true proportions, and his criticisms upon our country were received with respect and thankfulness.

It was in February, 1886, that I last saw Mr. Spencer. He had perceptibly aged, and appeared feeble. I did not tarry long, for I fancied conversation wearied him. As he took my hand at parting, he said, mournfully, "Tell Youmans you have seen me, that I have not much strength left, and I shall never see him again." What he had in mind was his own decease; but Prof. Youmans passed on to the majority before him. Since that day, we have reports of a long illness, from which he has partially recovered. There is small likelihood that the "System of Synthetic Philosophy" will ever be completed, but Mr. Spencer's energy is great and he will work as long as work is possible.

Turning, now, from the author to his productions, the first thing to be said - and it should be distinctly understood as incontrovertible - is that Herbert Spencer is the father of the modern philosophy of evolution. The impression still exists that Darwin is entitled to that honor. 'This is a mistake, which the application of the term "Darwinism" to that philosophy has helped to perpetuate. The "Origin of Species" was first published in November, 1859. Mr. Spencer's Psychology, it will be remembered, appeared in 1857. This last was preceded by several essays outlining the doctrine of evolution, the earliest of which dates from 1852. To one of these, "The Development Hypothesis," Mr. Darwin refers in the Introduction to the "Origin of Species." But the "Principles of Psychology," which is an integral part of Mr. Spencer's philosophy, and which exhibits the doctrine of evolution as it stands to-day, had been published two years before Darwin's first great work appeared.

'This, however, is by no means all. In its subject-matter Evolution is not "Darwinism," but a natural law of much broader scope. 'The former shows that, universally through- 
out nature, change is governed by a principle according to which there is a course of integration of forces from indefiniteness, simplicity, and homogeneity in their relations, to definiteness, complexity, and heterogeneity. When evolution, proceeding in this way, ceases, a reverse movement of dissolution begins. This law applies to inorganic and organic nature alike. Darwin's Natural Selection is an expression of the manner in which evolution accomplishes the development of vegetal and animal life, showing how species are formed, distributed, modified, perpetuated and destroyed.

It will thus be seen that, while $\mathbf{M}$ r. Spencer thought out and presented the whole philosophy of evolution, Darwin's work was special and limited. That it was a great work I am certainly not disposed to deny, but I think we ought to understand exactly what it was. It cannot better be expressed.than in an estimate by Geo. J. Romanes, published in Nature. "The few general facts out of which the theory of evolution by natural selection is formed, namely, struggle for existence, survival of the fittest, and heredity, were all previously well-known facts. . . But the greatness of Mr. Darwin, as the reformer of biology, is not to be estimated by the fact that he conceived the idea of natural selection; his claim to everlasting memory rests upon the many years of devoted labor whereby he tested this idea in all conceivable ways - amassing facts from every department of science, balancing evidence with the soundest judgment, shirking no difficulty, and at last astonishing the world as with a revelation by publishing the completed proof of evolution. ... In the chapter of acciclents, therefore, it is a singularly fortunate co-incidence that Mr. Darwin was the man to whom the idea of natural selection occurred; for although, in a generation or two, the truth of evolution might have become more and more forced upon the belief of science, and with it the acceptance of natural selection as an operating cause, in our own generation this could only have been accomplished in the way that it was accomplished; we required one such exceptional mind as that of Darwin, to focus the facts and show the method."

Mr. Spencer's practical philosophy has been pretty fully set forth in his "Data of Ethics," and in his various essays. In ethics he holds that conduct should be estimated and governed by the rule of the highest utility, but believes that an ideal social state, involving an ideal development of 
character, should always be kept before the mind as a standard, to furnish that "counsel of perfection" which his opponent, Green, urges as necessary though from an entirely different point of view. This ideal morality is likely to be realized in the course of evolution, but until there is reached such a state of society as to make it practicable we must also recognize a code of relative ethics by which to conform our actions to our circumstances, and aid, so far as those circumstances will allow, the progress of mankind to the most perfect conditions. This code will involve a varying compromise between egoism and altruism. Mr. Spencer thinks the antagonism between these two will eventually disappear, because the working of social forces must inevitably produce the result that men will increasingly find their happiness in the welfare of others. Their egoistic gratifications will become sympathetic. Their highest selfish delight will merely be the lust of making other people delighted. In a word, individual happiness will only be complete in the social happiness. Mr. Spencer is surely right in this view. We never can wholly eliminate self-regarding ends. Our own action must ultimately be directed to securing our own pleasure and preventing pain to ourselves. But it is quite possible for us to so form our characters that our highest pleasure is the pleasure and welfare of others; and in the measure that this is completely achieved is the conciliation between egoism and altruism perfected.

Our author's political philosophy is as radically individualistic as that of William von Humboldt. He believes in the minimum of govermment, and is uncompromisingly opposed to all the socialistic tendencies of the time. With the militant regimes of continental Europe he has no sympathy, and in the industrial combinations that seek to build up strong organizations for the purposes of domination and dictation he beholds an equally pernicions despotism. Mr. Spencer would no doubt be a Mugwump in politics anywhere. He would not support political machines, nor would he favor concentration or centralization of power. He carries to an extreme the laissen-faire doctrine. With him society is always "a growth, not a manufacture," and he deems that attempts at regulation beyond the necessities of security are obstructive of social progress, because they interfere with the natural growth which is the thing needed, 
and which can only proceed from the exercise of individual spontaneity and freedom.

This principle has been misapplied in one important particular, as it seems to me. Mr. Spencer's views of the limitation of the functions of government lead him to the notion that the State should have nothing to do with education, which, he thinks, should be accomplished entirely by private agency. Schools maintained by the public, and regulated by governmental administration, should be done away with. The fundamental mistake here is an error of omission. Those who hold these ideas fail to perceive that education is necessary as a measure of security. Though they may see that the root of all evil lies in the character of men, they do not appreciate that mere negative prohibition is not enough to secure that free and full derelopment of individuals upon which they lay so much stress. There must be placed over human beings, in early life, such a discipline of the will and of the intellect as to develop the social in opposition to the selfish disposition. This is by far the most certain means of preserving the peace. And if the ideal of the perfect State be a community where there is little or no government, such an ideal can only be realized by the creation of a predominantly altruistic character in individuals. How, then, are we justified in saying, when -we allow that government exists for the purpose of securing people in their freedom, that we ought to neglect those means which are evidently the most efficient for the desired end? For security's sake, therefore, the State ought to have a care for education, and maintain a system of public instruction and discipline.

There is little to find fault with in Mr. Spencer's notions of the general course which education ought to take. He asks the question, What knowledge is of most worth? and answers it according to a broad view of utilities. Those things which are directly necessary to self-preservation come first: then those indirectly ministering to this end, and to the full development of human nature. Physical, intellectual and moral education all have their place in proper proportions. The treatise on "Education" probably has been more widely read than any other of Mr. Spencer's writings, and it is likely to be regarded as a classic on that subject for a long time to come. It subordinates the æsthetic to 
the scientific, but it concedes the value of the former as a supplement to scientific knowledge and training.

Mr. Spencer's religious views are readily discernible to any one who has read the "First Principles" of his philosophy. Supernatural revelations he rejects; but to say that his scheme has no place for religion would be a gross mis. statement. He makes all nature dependent upon and the outcome of a Power which is not and cannot be known, but whose existence must ever be postulated. Toward this Power, faith may turn, but what it is must forever transcend our knowledge; and respecting its nature or attributes, those relating to personality included, no affirmations or denials can be made. This is strictly Agnostic doctrine, and it presents to us the famous "Unknowable," lespecting which so much has been said.

If the term be used absolutely, "Unknowable" is not a proper characterization. To be able to affirm that it exists, implies some knowledge of it; and it is a contradiction to declare that anything which can be made an object of cognition is unknowable. In a relative sense, however, the term may be used to mean something existing, but beyond the reach of further objectification, or of cognition by human intelligence as we have experience of it. 'This, no doubt, is what Mr. Spencer intends. The true statement is that we know the existence of an Ultimate Reality which is known as such but not otherwise known.

Here is our philosopher's creed, in a passage from "First. Principles": "Thus the consciousness of an Inscrutable Power, manifested to us through all phenomena, has been growing ever clearer; and must eventually be freed from its imperfections. The certainty that on the one hand such a Power exists, while on the other hand its nature transcends intuition and is beyond imagination, is the certainty towards which intelligence has from the first been progressing. To this conclusion science inevitably arrives as it reaches its confines; while to this conclusion religion is irresistably driven by criticism. And satisfying, as it does, the demands of the most rigorous logic at the same time that it gives the religious sentiment the widest possible sphere of action, it is the conclusion we are bound to accept without reserve or qualification."

Let us also note the following passages showing the true relationship of religion and science : 
"In religion let us recognize the high merit that from the beginning it has dimly discerned the ultimate verity, and has never ceased to insist upon it. . . . From the first the recognition of this supreme verity, in however imperfect a manner, has been its vital element; and its various defects, once extreme but gradually diminishing, have been so many failures to recognize in full that which is recognized in part. The truly religious element of religion has always been good; that which has proved untenable in doctrine and vicious in practice has been its irreligious element: and from this it has been ever undergoing purification.

"And now observe that, all along, the agent which has effected the purification has been science. We habitually overlook the fact that this has been one of its functions. Religion ignores its immense debt to science: and science is scarcely at all conscious how much religion owes it. Yet it is demonstrable that every step by which religion has progressed from its first low conception to the comparatively high one it has now reached, science has helped it, or rather forced it, to take: and that even now science is urging further steps in the same direction. . . . O Otherwise contemplating the facts, we may say that religion and science have been undergoing a slow differentiation; and that their ceaseless conflicts have been due to the imperfect separation of their spheres and functions. Religion has, from the first, struggled to unite more or less science with its nescience; science has, from the first, kept hold of more or less nescience as though it were a part of science. Each has been obliged gradually to relinquish that territory which it wrongfully claimed, while it has gained from the other that to which it had a right; and the antagonism between them has been an inevitable accompaniment of this process. . . . . So long as the process of differentiation is incomplete more or less of antagonism must continue. Gradually, as the limits of possible cognition are established, the causes of conflict will diminish. And a permanent peace will be reached when science becomes fully convinced that its explanations are proximate and relative; while religion becomes fully convinced that the mystery it contemplates is ultimate and absolute." (Part I., Chap. V.)

These, in barest outline, are some of the things that Herbert Spencer has begun to teach the human race. The fields of knowledge are wide, and many have been the la- 
borers therein. We appreciate and admire the work of the scientist who increases the stock of human learning in any of its departments. Agassiz, Darwin, Huxley, Tyndall, Wallace, and all the host of them, awaken our gratitude and command our reverence. But though we have traveled much in these realms of gold,

"And many goodly states and kingdoms seen,"

profounder emotions are stirred when we contemplate Mr. Spencer and his work. We think no longer of the ingenious mechanisms and marvelous adaptations of nature; the wonderful order, the many beauties, the curious things revealed and displayed for our observation and study. Rather, it seems as if barriers were suddenly thrown down, and a vision opened of boundless knowledge and exhaustless being. Then, our past experience becomes merely the arch where-thro'

"Gleams that untraveled world whose margin fades

Forever and forever when we move."

Then feel we, rather,

"Like some watcher of the skies

When a new planet swims into his ken."

Or, again, like Cortes,

"When with eagle eyes

He stood at the Pacific, and all his men

Looked at each other with a wild surmise,

Silent upon" that "peak in Darien." *

* Besides what comes from the personal knowledge of the writer, the authority for statements of facts in the foregoing essay may be found in two articles on Herbert Spencer and his works in the "Popular Science Monthly," one in the issue of November, 1874, the other in the issue of March, 1876, both by the late Prof. Edward L. Youmans, and also in the paper entitled "Herbert Spencer and the Doctrine of Evolution," in Cazelles' "Evolution Philosophy," publisher by D. Appleton \& Co. in 1875 . The writer wishes furthermore to acknowledge his indebtedness to Miss Eliza A. Youmans for several valuable suggestions. 


\section{ABSTRACT OF THE DISCUSSION.}

Mr. JAMes A. SkiltoN:-

Before entering upon the discussion of the admirable essay of Mr. Thompson, I may be permitted, having had little or nothing to do with its preparation, to congratulate you on this splendid programme of Essays and Readings upon the subject of Evolution. It may seem too much to say at this time, but I believe it will give a great impulse to the study of Evolution in the Christian church and elsewhere in America, and may produce effects now expected by few. Personally holding this opinion with tenacity and entire conviction, I might nevertheless not be willing to express it here and now if $I$ stood alone in entertaining it. But I am made bold to utter it by the fact that $I$ am in possession of the opinion of the Master himself on the subject, as expressed in the letter which I will now read:

\section{"Dear Sir:}

"The Nook, Horsham Road, Dorking,

"I am obliged by your letter of July 11th, with its enclosures. I am glad to say, and you will perhaps be glad to hear, that I am considerably better than when I gave to Dr. W. J. Youmans the impression you quote. Leaving London in a rery low state about a month ago, $I$ have since improved greatly, and am now in hopes of getting back to something like the low level of health which I before had, though I scarcely expect to reach that amount of working power which has been usual with me.

"The information contained in your letter was, I need hardly say, gratifying to me both on personal and on public grounds. The spread of the doctrine of Evolution, first of all in its limited acceptation and now in its wider acceptation, is alike surprising and encouraging; and doubtless the movement now to be initiated by the lectures and essays set forth in your programme will greatly accelerate its progress - especially if full reports of your proceedings can be circulated in a cheap printed form. The mode of presentation described seems to me admirably adapted for popularizing evolution views, and it will, I think, be a great pity if the effect of such a presentation should be limited to a few listeners in Brooklyn.

"Wishing you and your coadjutors every success in your efforts, "I am, truly, yours,

"Mr. J. A. Skilton."

"Herbert Spencer." 
Happening to have in my possession early in the summer an advance copy of your programme, it occurred to me that it might be to Mr. Spencer a comfort and a consolation, if not an aid to a renewal of strength, to learn what you were proposing to do; and I therefore sent him a copy of the programme, together with a letter of cordiul sympatily; to which the letter just read is his reply. I subsequently learned, from Mr. W. R. Hughes of Birmingham, the President of the Sociological Section of one of them, that Mr. Spencer had caused the programme and my letter to be forwarded to societies in England and France engaged in the study and advancement of Evolution Philosophy, as matter of interest to European Evolutionists.

In listening with pleasure to the essay of the evening, I have found but one statement open to criticism. It seems to me we may believe the world has been blessed in that $\mathrm{Mr}$. Spencer was not biased by a thorough academical education, but was left to the natural development of his intellectual powers untrammeled by direct and overmastering academic influences. His refusal to accept the alleged privileges and opportunities of such an education while yet a mere boy, marks, to my mind, the early self-recognition of those splendid natural powers by which the world has been already greatly benefited, and will continue to be benefited throughout the ages. I make only a passing allusion to this subject, which it would be out of place to discuss here at length; but I may be permitted to say that the history of the development of the mind and philosophy of Herbert Spencer is most instructive and interesting; that the great advances in the thought and work of the world are almost never made by those of the "guild," and that we should probably have marred rather than mended if we could have had it otherwise.

The time allotted me permits mention of only two or three incidents in that history. Examination of the original English edition of "Social Statics," published in 1850, discloses to us the aetion of a mind as yet dominated by its intellectual environment; the facts presented, the line of thought pursued, and the method of treatment adopted, being such as many of his contemporaries might naturally have employed in dealing with the subject. We find in that work little of the promise of the splendid fruitage we have already garnered from his subsequent works, except that derivable from the exhibition of transparent intellectual honesty and love of truth. Turning thence to the American edition of "Social Staties," published by the Appletons in 1865, we find that spencer consented with relnctance to its publication 
unchanged, and with prefatory qualification of the most important character, in the following words: "But in restating them he would bring into greater prominence the transitional nature of all political institutions, and the consequent relative goodness of some arrangements which have no claims to absolute goodness."

Between 1850 and 1865, then, Mrr. Spencer had discovered the vast and most important difference between absolute and relative morals and principles, a difference which lies at the very foundation of his entire system of philosophy. When and how was he led to discover that difference? Looking over the list of his writings, we note his article on "Population," printed in the Westminster Reriew of July, 1852. That article commences with a reference to the Malthusian Theory of Population, and quotes approvingly the language of a sagacious and benevolent man, who said of it: "A time will come when this mystery will be unveiled, and when a beneficent law will be discovered, regulating this matter, in accordance with all the rest that we see of God's moral government of the world"; and forth with Mr. Spencer proceeds to promulgate such a law. In that article we find recognition of that difference, and accompanying the same an unmistakable prophecy of the beneficent ethical philosophy disclosed in the "Data of Ethics," that lights the way through all the wilderness of his work and thought that lies between them.

It is a matter of associated interest to note that, according to the biography of Darwin, written by his son, it was the reading, in 18:39, of the "Theory of Population," by Malthus, that gave him also an initial impulse for his splendid work in the field of the Struggle for Existence and Natural Selection. It is also of interest to note that, according to the history of the development of the thought of earlier ages, substantially the same great question and collection of questions occupied the attention of the great minds concerned in laying the foundations of Judaism and Christianity, and whose action has so powerfully influenced the history of the world.

In these facts we may at least find warrant for the study and investigation of the Evolution Philosophy in and through an Ethical Association attached to a Christian church and holding its sessions in its place of worship.

\section{Rev. Johr W. CrradWick :-}

Mr. Chadwick expressed his pleasure in listening to the delightful essay by Mr. Thompson. He presumed that in claiming for Mr. Spencer the paternity of the Evolution philosophy, the essayist did not intend to ignore the prior claim of Darwin to the con- 
ception of Evolution or Development in its biological aspects. Darwin commencerl the investigations which resulted, finally, in the preparation of the "Origin of Species," twenty years prior to its publication,-before Mr. Spencer had begun his eareer as an author. Mr. Spencer's acquaintance and friendship with "George Eliot" he also thought worthy of note.

As to Spencer"s conception of the Absolute as Unknowable, $\mathrm{Mr}$. Chadwick had always felt that, even according to Mr. Spencer's own definitions, though unknown it was at the same time wellknown; though hidden from us in its totality it was revealed in the entire phenomenal universe, where the method of its operation was open to our study.

\section{Mr. Thomas Garinner :-}

The really essential features of Mr. Spencer's system have been lucidly presented by the essayist, and his criticism has also been judicious. Although I confess myself a devout follower of Mr. Spencer, I cannot bring my mind into subjection to his views as to the powers and province of government, and think that the "laissez-faire" system which he so confidently advocates is not always the best for a community or nation. I think there is not a little wisdom in the words of Edmund Burke, when he said, "Before I congratulate a people on having obtained their liberty which will allow them to do as they please, I think it wonld be well to wait and see what it will please them to do." I must confess that my bent of mind inclines me to sympathize more, in the matter of government, with the fervid aspirations of John Ruskin than with the colder reflections of Herbert Spencer.

Although no one has written on the subject of ethics in a simpler and clearer manner than $\mathrm{Mr}$. Spencer, it has been his fate to be, whether wittingly or unwittingly, grossly and widely misunderstood; and it was refreshing to listen, to-night, to an exposition of his views on this crowning work of his life, wherein the really noble and tender sentiment underlying $\mathrm{Mr}$. Spencer"s speculation has been sympathetically presented. I am certainly of the opinion that the basis of his philosophy is a profoundly religious one, and look upon the attitude of the Agnostic, when confronted with the shadow of an unknowable and infinite deity, as pre-eminently reverential and worshipful. It is, I think, beyond question that all deep religious emotion finds its birtlpplace in a mystic region; and surely, in the noble range of the Evolution philosophy, there is a mystic region large enongh to satisfy the aspirations of the most devout dreamer : in fact it is beyond the bounds of all time and space. 


\title{
CHARLES ROBERT DARWIN
}

\author{
BY \\ JOHN W. CHADWICK

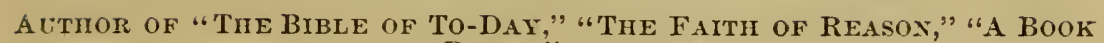 \\ of POEMS," ETC., ETC.
}




\title{
COLLATERAL READINGS SUGGESTED
}

\author{
IN CONNECTION WITH ESSAY II.
}

Life of Darwin, by Francis Darwin; Life of Darwin, by G. T. Bettany; Life of Darwin, by G. W. Bacon; Darvin, by L. C. Miall; Charles Darwin: his Life and Work, by Grant Allen; Biographical Sketch of Darvin, by Asa Gray (in Proceedings of American Academy of Arts and Sciences, Vol. XVII., p. 449); Fiske's Darwinism and other Essays; Darwin's Geology and Natural History of the Countries Visited by H. M. S. Beagle; Wallace's Contribution to the Theory of Natural Selection; Leibnitz's Monads; Lamarck's Zoological Plilosophy; Robert Chambers' Vestiges of Creation; Draper's Conflict between Science and Religion. 


\section{CHARLES ROBERT DARWIN.*}

Wно does not know the story of Dr. Samuel Johnson's penance in the market-place of Uttoxeter? - how, when a boy, he had refused to go there for his poor old father, who therefore must needs go himself, and stand there, sick and weary, at his stall, tending his stock of books; how, when a man and at the summit of his fame, he went down to Lichfield, and from there out to Uttoxeter, close by, and stood bareheaded in the blazing sun, just where his father's stall had been, speaking no word to any man or maid, much woudered at for one sad hour by the motley crowd of traffickers - for it was market-day. At the time of this occurrence Lichfield was a literary centre of considerable selfimportance. Dr. Johnson thought but slightingly of it, and probably sought out no member of the Lichfield coterie on the occasion of his famous visit. But here was Mr. Day, the author of "Sandford and Merton," who had his portrait painted with a flash of lightning playing through his hair and illuminating the pages of the book held in his hand. Here was Mr. Edgeworth, father of the excellent Maria, making love to his second wife, Honora Sneyd, in the lifetime of the first, who had eventually four successors. Honora Sneyd was the object of a passionate attachment on the part of Major André, the unhappy spy. She lived in the cathedral-close, an adopted daughter of Canon Seward, whose own literary pretentions were not slight, and whose daughter Anna was called the Swan of Lichfield. She was extremely sentimental, according to the fashion of the time. She covered many reams of paper with her verses of the frosted-cake variety, and wrote besides a good deal of criticism and biography. An essay in the last-named direction is perhaps her best security from complete oblivion. It is a biography of Dr. Erasmus Darwin, who was born in 1731 and died in 1802. He was the most original and important member of the Lichfield coterie. The description of his

* Copyright, 1889, by 'The New Ideal Publishing Company. 
personal appearance furnished us by the Swan of Lichfield reminds us in not a few particulars of Dr. Johnson. He was heavy-featured, corpulent, unwieldly; a stammerer in his speech; with great gifts of conversation, witty and salcastic. With him as with the Ursa Major, a rough ontside concealed a heart extremely tender and even capable of sentimental softness. In the practice of his profession his generosity and charity were not confined to Lichfield, but made him loved and honored all the country round. For a favorite patient, for whose restoration he had ceased to hope, he composed an elegy, thus wearing out the sorrow of an anxious night spent out-of-doors beneath her window watching the shadows of her attendants pass and repass. But she recovered and her husband died, and Dr. Darwin married her. His most famous poem occupied him many nights and many busy days. It was "The Botanic Garden," which, with its second part, "The Loves of the Plants," was published in 1791. It was the work of a man who. was little of a poet and much a man of science. Its diction is pompous and stilted to the last degree; its machinery of gnomes and sylphs and nereids was as absurd as Canning's parody, "The Loves of the Triangles." But with $£ 900$ in his pocket for his poem, the Doctor could afford the laugh. It showed him thoroughly acquainted with the system of Linnæus. In his "Zoönomia," published a little later, he dropped into prose. In this work he anticipated Lamarck's conception of organic continuity and some of the erroneous grounds of his conviction. His theory of Beauty was that it inheres in curving lines and surfaces. The sense of Beauty is a reminiscence of the infant's pleasure in the contours of its mother's breast. "Wherefore a child brought up by hand," said Sheridan, "should thrill with rapture in the presence of a wooden spoon." But, however fanciful at times, the average temper of the man was patient and discerning. He was no echo of the past, but a rude prophet of the coming man, even of his grandson, Charles Robert Darwin, who established the doctrine of organic continuity upon irrefragable foundations.

Robert Waring Darwin was the third son of Erasmus by his first marriage, - which was not with the elegiac lacly. He followed the profession of his father, and contined himself to it more closely, and with results generally satisfactory. He was eminently skillful, and he acquired a hand- 
some fortune, which was doubtless much increased by his marriage with the daughter of Josiah Wedgwood, of ceramic name and fame,- a man of admirable qualities and great force of character. Coming of such parents and such grandparents, Charles Robert Darwin was certainly well born, with a hereditary claim upon the virtues of patience and fidelity. If the scientific passion of Dr. Erasmus Darwin appeared in him, so did Josiah Wedgwood's sense of form. "The Origin of Species" is as symmetrical as the Portland vase of Wedgwood's admiration; its arguments stand out in as clear relief as the figures on that thing of beauty. But the life of Darwin was of a beauty even more complete.

Darwin was born in Shrewsbury, February 12, 1809. He was sent to Edinburgh in 1825 , it being intended that he should follow the medical profession, and the Edinburgh facilities for studying medicine were at that time unequaled. But he took little interest in his studies, and made little progress. He was taken from Edinburgh after two years of futility, and sent to Cambridge. If medicine could not excite his interest, might not theology? Possibly it might have done so if there had not been at Cambridge a Professor Henslow; before meeting him he tells us the only objects of natural history that he cared for were foxes and partridges, and his interest in these was hardly scientific. But henceforth all was changed. His interest in natural history became intense and all-engrossing. A field-excursion under the guidance of Professor Henslow was his chief delight. His name appeared for the first time in print as the capturer of a certain bug on one of these occasions. Little he dreamed, as thus he saw it, not without honorable pride, what a standard it was yet to be for men to rally under in the cause of Ormuzd, Prince of Light, against Ahriman, the Prince of Darkness!

A description of Professor Henslow from his pen is said by those who knew him well to be quite perfect as an account of his own character. "Nothing could be more simple, cordial, unpretending, than the encouragment which he afforded all young naturalists. . . . When I reflect how immediately we felt at perfect ease with a man older, and in every way immensely our superior, I think it was as much owing to the transparent sincerity of his character as to his kindness of heart, and perhaps even still more to a highly 
remarkable absence in him of all self-consciousness. . . . His manner to a distinguished person and to the youngest student was exactly the same. . . . It always struck me that his mind could not well be touched by any paltry feeling of envy, vanity, or jealousy. With all this equability of temper and remarkable benevolence, there was no insipiciity of character. . . When principle came into play, no power on earth could have turned him a hair's breadth. . . . In intellect, so far as I could judge, accurate powers of observation, sound sense, and cautious judgment seemed predominant. Nothing seemed to give him so much enjoyment as drawing conclusions from minute observations. Reflecting upon his character with gratitude and reverence, his moral attributes rise, as they should do in the highest characters, in pre-eminence over his intellect." These sentences impress us as if the writer had in some stainless mirror perceived the lineaments of his own mind and heart and ascribed them to another.

We speak of Darwin's as an uneventful life, but it was an event of no small importance for him to meet and for four years be subject to the constant influence of such a man as this. Something of essential kinship there must have been between them, but it may well be doubted whether the likeness in the younger to the older man would have come out so vividly if there had not been this long and close relation. From this first event sprang another of remarkable significance: his sailing in the "Beagle" on a cruise of survey and general observation. This splendid opportunity came to him from Professor Henslow, who was deputed by the captain of the "Beagle" to select a promising young naturalist to accompany him, without salary but without expense. Darwin's father gave his consent reluctantly, fearing that so novel an experience might unsettle him for the church, _ as verily it did. He sailed in December, 1831, and returned in October, 1836. In the "Voyage of the Beagle, a Naturalist's Voyage Round the World," he set down only a part, albeit a very large and interesting part, of all his observations. Had he written nothing else but this, it would have ranked him high among the naturalists of his century. But it is as interesting to the average reader as it is important to the man of science. The germs of almost everything developed in his later writings can be discovered here; notably the germ of his most character- 
istic doctrine, - the transmutation of species by means of natural selection and the preservation of the fittest. The phenomena of plant and animal life in the Galapagos Islands first impressed him with the need of such a doctrine to account for the geographical distribution of organic forms. From his return in 1836 to the publication of the "Crigin of Species" in 1859, all of his studies and his various publications were leading up to this, the climax of them all. In 1839 he married his cousin, Emma WVedgwood, and in 1842 took up his residence at Down, in Kent, - where he lived until his death, a period of forty years. A generous fortune permitted him to abstain from all breadwinning employments and to devote himself entirely to his favorite studies. His was a quiet, beantiful, and happy home. His boys, as they grew up, could not resist the fine contagion of the observant habits of his life. In due time there was a family of naturalists, aiding, correcting, and encouraging each other. The father's later writings blossom thick with references to observations and experiments made by his sons. As early as 1837 we find him reading a paper to the Geological Society on the "Formation of Vegetable Mould." His latest publication, which appeared not long before his death, was an amplification of this early paper. It was not that he resumed a subject he had laid aside; he had been waiting for his experiments to ripen. For forty years and more the earthworms had been carrying on his work, answering his pressing questions. The last result was Beauty for Ashes, a new and wondrous meaning in the ancient words, "I will say to the worm, Thou art my brother and my sister" - a brother and a sister to whom we have every reason to be grateful, and of whom we may well be proud.

In 1842 he published "Structure and Distribution of Coral Reefs"; in 1844, "Volcanic Islands"; in 1846, "Geological Observations in South America." All of these publications were the outcome of his voyage in the "Beagle," and, together with the geological chapters in the "Origin of Species," they are convincing of the truth of Dr. Geikie's saying, that "No man of his time has exercised a profounder influence upon the Science of Geology than Charles Darwin." If his geological writings had been exhaustive of his intellectual activity, his fame would be as enviable as that of Agassiz or Lyell or any other contemporary geol- 
ogist. To the leading thought of Lyell, that the geologic past finds a sufficient explanation in the present state and tendency of things, his various studies brought emphatic confirmation. His essay upon "Coral Reefs" proved their origin in surface water, and deduced the conclusion of wide areas of oceanic subsidence. "If he had written nothing else," says Geikie, "this treatise would alone have placed him in the very front of investigators of nature." If less original, not less masterly were his works upon Volcanic Islands and the Geology of South America. The latter sought, and not in vain, to prove the slow and interrupted elevation of the South American continent within a recent geological period. But it was in the relations of geology to biology that the geological results of Darwin were most levolutionary and important. His chapter in the "Origin of Species" on the "Imperfection of the Geologic Record" proclaimed upon the house-tops what had before been only whispered in the ear, and very timidly. He proved that, by the very conditions of its formation, the geological record must be intermittent and fragmentary. Hence, in its character there was no argument, as generally assumed, against the genetic continuity of species, but in such continuity a conclusive evidence of the record's incompleteness.

In the meantime Darwin was brooding patiently over the idea of natural selection which had been suggested to his mind by the zoölogical phenomena of the Galapagos Islands, and in 1844 he made known the outlines of his theory to Lyell and Hooker. But he had not, apparently, the slightest disposition to take the general public into his confidence. Another seven years went by, and still another, and found him still making experiments, still collecting facts, still trying to anticipate all possible objections. "He that believeth shall not make haste"; and Darwin might have gone on for another twenty years thinking and probing, but for the fact that in $1858 \mathrm{Mr}$. Alfred Wallace sent him an essay, based upon personal studies of the Malay Archipelago, which was no more nor less than an expression of Darwin's own most characteristic thought. This essay was soon after published, jointly with extracts from Darwin's exposition of 1844; and, soon after, Lyell and Hooker persuaded Darwin to publish his own views more fully, and this he did in 1859, when he was already fifty years of age. This publication was the famous "Origin of Species," 
the most notable of nineteenth century books, an epochmaking book if ever there was one. The amenities of scientific literature have not a brighter page to show than those recording the mutual relations of Darwin andWallace as simultaneous promulgators of the grandest generalization of the modern world. Darwin was ever quick and generous in his assertion of the independent origin of $\mathrm{Mr}$. Wallace's conclusions, and $\mathrm{Mr}$. Wallace was never backward in declaring not only the priority of Darwin's view, but the less comprehensive and conclusive character of his own investigations.

"The Origin of Species" was not intended as an exhaustive statement of the argument for natural selection, but only as an outline of this argument. But it was an outline in some five hundred closely printed pages, an outline that a less exigent spirit would have thought sufficiently exhaustive. It was the hope of Darwin to fill out this outline of his theory in all its parts. What the extent of the work would have been if he had done so can be inferred from the extent of "Animals and Plants under Domestication," published in 1868 . Here, in two volumes, we have a thousand pages which are only an expansion of the first chapter in the "Origin of Species." There is every reason to believe that Darwin had at his command a range of observation and experiment that would have enabled him to expand every chapter in the "Origin of Species" to a like clegree. But for such expansion there seemed to be no crying need. Other men were entering into his labors and carrying them on with great enthusiasm and success. Nevertheless, all that he wrote, with hardly an exception, after the "Origin of Species" was to confirm and illustrate the doctrine of that marvelous book. Indeed, he found it quite impossible to study any aspect of nature that did not fall into line with his supreme idea. The nature of his studies may be gathered from the titles of his successive works: — "Fertilization of Orchids," "Cross and Self Fertilization of Plants," "Forms of Flowers," "Movements and Habits of Climbing Plants," "Insectivorous Plants," "Movements of Plants," "The Descent of Man and Sexual Selection,"- the second part of which was an expansion into five hundred pages of a few paragraphs in the "Origin of Species,"and the book on "Earthworms" and "Artificial Selection under Domestication" of which I have already spoken. 
To these general publications must be added many papers contributed to different societies and printed only in their archives. As I have read the titles you have noticed that a great majority belong to books of a botanical series. And it is true of Darwin that while his earlier writings, before the "Origin of Species," were mainly geological, those of his later life were mainly botanical. He never professed to be a botanist; he disclaimed the right to be considered one; but one of the first of living botanists has said of him that "each of his botanical investigations, taken on its own merits, would alone have made the reputation of any ordinary botanist." But even the aggregate of these separate investigations does not afford a measure of Darwin's contribution to botanical science. The general influence on this science of his leading doctrine has been incalculably great. Before the announcement of this doctrine the geographical distribution of plants was an insoluble riddle. To-day it is a riddle that has been as completely read as any that the mighty Sphinx of nature has propounded to mankind.

But to return to Darwin's greatest and most characteristic work, "The Origin of Species by Means of Natural Selection," published in 1859. Original and revolutionary as it was, it is possible to exaggerate its novelty. "What is the theory it propounds?" asks one of its interpreters, and answers: "Broadly, this: The unity of all organic nature; that all animals now living - and similarly all plants - are connected, forming one great family; and not only so, but that they are connected with those of all past ages, and are in fact derived from them." And this is a concise and admirable statement of the popular idea of Darwin's greatest work. But it is a most erroneous idea. If such a doctrine had been exhaustive of Darwin's famous book, it would have had but little claim to novelty. For in 1859 this doctrine of the organic and genetic unity of plant and animal life upon the earth had already many powerful advocates. Goethe was one of them, Treviranus was another, Lamarck another, Erasmus Darwin another, our own Emerson another, the author of "The Vestiges of the Natural History of Creation" another, Herbert Spencer another and the most notable of all. 'Those who imagine that Darwin's characteristic doctrine was the genetic continuity of terrestrial life, both vegetable and animal, would do well to read 
an essay - it is very brief - published by Mr. Spencer in 1852 , seven years before the appearance of the "Origin of Species." It would disabuse them almost harshly of their absurd idea. They will find that Darwin never stated the general doctrine of development in a more comprehensive manner. If Darwin's claim to an original discovery rested upon his general doctrine of development, this essay would dispose of it forever. But it rests upon subordinate grounds. Undoubtedly his leading proposition is the unity of all organic life, and undoubtedly the importance of his book is greatly owing to the confirmation which it brings to this. But the characteristic work of Darwin was inclicated by the title of his book, "The Origin of Species by Means of Natural Selection." Not, so to speak, the what of family relationship between all plants and all animals, past, present, and to be, but the how of this relationship was what he set himself to show. Before his time the fact of such relationship was only a brilliant guess - or hardly more than this. Spencer had indicated some of the lines on which the argument must advance, - the difficulty of distinguishing species from varieties, the changes which various embryos undergo, the analogy of artificial variations. But there was no massing of the facts along these lines. There was this in Darwin's work, but over and above all this was the central purpose of the book: to show that species had originated by the preservation of favored races in the struggle for existence by means of natural selection. He did not contend that natural selection was the only means by which new species had originated, but he claimed for it a great and leading part, and he supported his claim by an array of evidence which commanded the respect of the intelligent, if it did not at once produce conviction.

The theory of Darwin received not long ago a mortal wound, - the last of several thousands,--from a great expounder of religion in New York, who declares that he would rather look for his ancestors in the Garden of Eden than in a zoölogical garden. The animals in the zoölogical garden would not, perhaps, regret a preference that is sure, if acted on, to leave their "great attractions" more unrivaled; but the remark is painfully significant of the average view of Darwin's teachings. It is commonly imagined, thanks to the teachers of the popular theology in no small degree, that Darwin's "Origin of Species" was de- 
voted primarily and exclusively to showing that the ancestors of mankind were monkeys at no great remove. In fact, the "Origin of Species" contained next to nothing about monkeys, and very little about man, to derive whose ancestry there was no attempt whatever. But the implication was natural and unavoidable: if other species were not the results of special creation, the human species could be no exception to the rule. Darwin himself had not the slightest disposition to deny this implication or to palliate its force. Mr. Wallace, agreeing with him as to the sweep of natural selection beyond the confines of humanity, contended that the development of man from ape-like ancestors could not be thus accounted for. Darwin could not allow the force of his objections. In 1872 he published "The Descent of Man." What was implicit in the "Origin of Species" was here made explicit. But it was a subordinate matter. Darwin's principal and most characteristic work was not to explicate our human origins. It was to account for the origin of species by the law of natural selection instead of by the notion, fancy, what you will, of special creation. The descent of man from anthropoidal apes is a single illustration of this law, - a very interesting one to us, but it is only a single illustration.

Consider with me the course of argument by which Darwin eudeavored to establish this law of natural selection. He set out with showing to what a wonderful extent artificial selection on the part of man can vary animals and plants. May there not be a law or principle in nature corresponding to the artificial selection of the horse-breeder, the pigeon-fancier, the horticulturist and floriculturist? He answered, Yes, and showed how much more general and effective it must be than any conscious or unconscious art of man. "Man can act only on external and visible characters: Nature cares nothing for appearances except in so far as they may be useful to any being. She can act on every internal organ, on every shade of constitutional difference, on the whole machinery of life. . . . It may be said that natural selection is daily and hourly scrutinizing throughout the world every variation, even the slightest; rejecting that which is bad, preserving and adding up all that is good; silently and insensibly working, whenever and wherever opportunity offers, at the improvement of 
each organic being in relation to its organic and inorganic conditions of life." In the struggle for existence, always going on, it is evident that individuals having the least advantage over others will have the best chance of surviving and of reproducing their kind. In all living forms there is a certain tendency to variation. Natural selection is a principle which preserves the variations which are favorable to the life of any individual or race. By accumulating favorable variations in one variety or species it makes the chances of a competing variety for success or even for survival less and less. Hence the extinction of certain races. But natural selection also leads to divergence of character; for the more the living beings that can be supported on the same area, the more they diverge in structure, habits, and constitution. The more diversified the descendants of any species become, the more likely will they be to succeed in the struggle for existence. "Thus the small differences distinguishing varieties of the same species will steadily tend to increase till they come to equal the greater differences between species of the same genus, or even of distinct genera."

The facts to be accounted for are innumerable adaptations of organisms to their environment. The traditional method for accounting for them is that of special creations. Now, if it could be shown that all the different species were suddenly adapted to their environment, we should have ample proof of special creation. But if it can be shown that nowhere is there sudden adaptation, and that one set of adaptations can be gradually transformed into another, then we have ample proof of organic evolution and of natural selection as a method of this process. For no one will be likely to deny that if there is organic evolution by which species are transmuted, natural selection is its principal though not its only instrument. What, then, are the evidences of organic evolution?

First, they are such as are furnished us by the scientific classification of the animal and vegetable world. This classification is not something arranged by Darwin and his confederates. If it were so, we might suspect it of some bias from their prepossessions. But Darwin found it waiting for his hour, ready to ery Amen to his ideal. He found his principal antagonists working away at it and 
making it more perfect and with every stroke confirming his opinions. Thus, for example, Professor Agassiz produced no greater work than his "Essay on Classification." You know that he was strenuously opposed to Darwin's theory. But his Essay on Classification was unwittingly an argument in its behalf. Mr. John Fiske informs us that it was convincing to him of organic evolution before Darwin's book appeared. But let us see how it is that a system of classification is an argument for organic evolution.

The classification of plants and animals has occupied the scientific mind for many centuries. The earliest classifications were all popular and semi-popular; that is to say, they were based upon external resemblances. A whale was called a fish because it had the general form and habits of a fish. Even the great Buffon questioned whether a crocodile should not be classified as an insect because the hardness of its casing corresponds to the hardness of a beetle's. He finally decided that the crocodile is not an insect, and for this reason: the crocodile is so large an animal that it would make "altogether too terrible an insect" !

The endless confusion growing out of such a superficial method suggested to Linnæus that internal structure rather than external appearance should be made the basis of classification. At once the sky began to clear. A natural system was worked out. It proved to be a tree-like system. A short trunk represents the lowest organisms, concerning which, when challenged, "Vegetable or Animal ?" we cannot say. This trunk soon separates into two great branches, one for the animal, the other for the vegetable, kingdom. Smaller branches springing from these represent classes; smaller from these, families; then orders, genera, and species bring us to the smallest branches, twigs, and leaves. Now, in this tree-like system we have just such a system as the evolutionist would naturally expect. It is "as clear" an expression as anything could be of the fact that all species are bound together by the ties of genetic relationship." Work it backward or forward and we get the same impression : forward, the gradual shading off of characters into forms more and more specialized is eloquent for the fact of transmutation; backward, the difficulty of determining the genus, order, class, of certain organisms of the humblest grades is most instructive. Proof there may not 
be here, but if the tree of classification does not suggest a corresponding tree of life to an intelligent mind, it must be because none are so blind as those who will not see.

Another: argument for organic evolution is that furnished us by the structural adaptations of plants and animals to their enviromment. For example, take the whales and porpoises. The theory of Darwin is that their progenitors were terrestial quadrupeds who by some change in the conditions of their life had to become aquatic. The least strongly inherited structures, such as skin, claws, and teeth, would first be affected. Gradually the whole outline of the body would become more fish-like, with bones and muscles better adapted for aquatic locomotion. We find the seals in this condition. The hind legs are much shortened, and directed backwards, so that they do not serve for walking in the least degree, but help to taper off the body in a more fish-like manner. In the whale the hind legs have retreated inside the skin. But, mind you, every change is of a sort that adapts the structure more completely to its aquatic life. "Thus the arm, which is used as a fin, still retains the bones of the forearm, wrist, and fingers, though they are all inclosed in a fin-like sack. On the other hand, the bat, another mammal, has the fingers enormously elongated and covered with a membranous web." The specialcreationist explains such things as these,-there are hundreds and thousands of them,- by a theory of ideal types to which the Creator is supposed to rigidly adhere. But the adherence is only so far as the needs of the animal require, and the degree of divergence from the typical form everywhere corresponds to the period of changed conclidions. The theory of adaptive modification accounts for all the facts. The theory of ideal types accounts for nothing but the unwillingness of men to give up an old opinion.

Closely allied to these considerations of adaptive structure is the matter of rudimentary organs - organs, that is, which no longer serve a useful purpose. Such are the teeth of whales that never cut the gums, of birds also; the wings of insects who never open or use them; the caudal vertebræ in man, and that miserable appendix vermiformis which so often causes death; the masculine breasts and certain muscles of the scalp and ear, and other similar things. The special-creationist again is ready for us with his theory of ideal types. But it amounts to noth- 
ing. It is a mere excuse for a foregone conclusion. It is dumb in the presence of such facts as the existence of rudimentary hind legs in certain snakes, their absence in the great majority. "Were God "so anxious for the type," he would at least have brought it out in the majority of cases. He would not have made the modern horse with three toes (the shank and splints), earlier horses with four, and still earlier with five, one of them rudimentary. Such a progression overwhelmingly suggests organic evolution, while the doctrine of ideal types finds in it not a particle of confirmation.

Another argument for organic evolution is the geological; viz., that no highly organized plant or animal occurs in the lower strata. This is the argument from temporal distribution. The argument from special distribution is one that Darwin has made peculiarly his own. Indeed, it was the argument which first impressed him with the general truth of natural selection. It is that differences of structure correspond to the degrees of separateness of local origin. The opposing continents have the widest differences, the continents and adjacent islands the next widest, and so on. So, too, the sea plants and animals on the opposite sides of a continent are most unlike. Is not the lesson of these facts so plain that a wayfaring man, though a fool, may not. err therein? What can they mean if not that degrees of resemblance mean degrees of special adaptation? Not an oceanic island situated more than three hundred miles from land has a mammal except the bat. The special-creationist would ask us to believe that God created here the only mammal that could get here of his own free motion! Also that on certain oceanic islands he has placed certain plants with hooks ingeniously adapted to catch the hair of passing quadrupeds and so disseminate their seeds. But the quadrupeds are wanting. Why but because the seeds could blow but the quadrupeds could not swim so far?

Last, but not least, we have the argument from embryology, - the condition of the young of various creatures previous to their birth. Take man for an example. In the earliest stages of his fotal life he cannot be distinguished from an incipient plant. Later he cannot be distinguished from the lowest animals; still later, when his vertebrate condition is determined, it cannot be said whether he is snake or fish or bird. When it is evident that he is to be a mammal, 
it is still doubtful whether he will be a dog, a horse, or a man. At a certain stage the human embryo has gill-slits in the neck, and arteries branching towards them as in a fish. Later the great toe projects at an angle laterally, as in the quadrumana. When well advanced, there is a tail longer than the legs at the same period, and with a good extensor muscle. The presence of hair all over the body, except the palms of the hands and the soles of the feet, at the sixth month of fœtal life is remarkably suggestive. What dowhat can - all these things mean if not that the embryonic stages of the individual man repeat the stages through which the human race has come? From the standpoint of organic evolution they are comprehensible enough. From the standpoint of special creation they present the Creator in no enviable light. $\mathrm{He}$ is like a man who, setting out to build a Cunarder, makes a dugout first and then refashions this into a raft, and this in turn into some clumsy junk or proa, and so on. But he is worse than this ; for, if he has pursued the method of special creation, he has done his best to make it seem to us that he has pursued the method of organic evolution. All the facts - and they are innumerable - are upon this side. There are only a tradition and a prejudice upon the other.

Such, briefly and nakedly, is Darwin's argument for the development of species by means of natural selection and the preservation of the fittest. To its illustration and its confirmation he has brought a countless multitude of facts, all tending to show that the progressive adaptation of plants and animals to their environment is procured by the heaping up of beneficial variations. It is an hypothesis which corresponds with natural classification, which accounts for structural adaptation and for rudimentary organs, which tallies with the geological reeord and with the geographical distribution of plants and animals, which at once explains the facts of embryology and finds in them its amplest confirmation. The most of you can well remember how it was at first received. The scientists and theologians vied with each other in their contempt ankl scorn. It was because the scientists were so often theologians in disguise. Hundreds and thousands of books and pamphlets and newspaper articles and sermons were poured out-so many vials of wrath - upon the quiet Kentishman, who in the meantime went on experimenting with his pigeons and insectivorous plants 
and earthworms, provokingly indifferent to the pandemoniuin which he had set a-going. The uivergence of his theory from that of Genesis was much insisted on, and certainly it was very great. Later attempts to show that it was not are less ingenuous than the original execrations. There were great men of science who joined with the little men of science and the theologians in the fierce onset. Even our noble Agassiz so far forgot himself as to tickle the ears of the groundlings with such ad captandum phrases as "We are not the children of monkeys; we are the children of God." But the great Lyell almost at once gave in his frank adhesion; Huxley, with real joy of battle, took the field against a world in arms; Spencer, the pre-established harmony of whose thought with Darwin's we have already noticed, hailed with exceeding joy the splendid special illustration of the general principles of evolution. With such magnificent approval Darwin could well afford the jeers of ignorance, the pious maledictions of the parsons and the priests. But in 1866, when the "Origin of Species" had been seven years before the world, he confessed to Haeckel that he had no hope of seeing any general recognition of his doctrine in his lifetime. The event was very different from his anticipation.

In 1872 he published the "Descent of Man." He had said nothing on this head in the "Origin of Species," perhaps because he knew what mountains of prejudice would become volcanic at the suggestion of our development from the lower animals He would have his general doctrine accepted or rejected as nearly as might be on its own merits. But the implication of his theory was so obvious that he might just as well have made a clean breast of it in the "Origin of Species." 'The implication was made explicit enough in 1872. His argument in 250 pages is so condensed that to attempt to summarize it is like trying to make the charcoal of a diamond more compact. Some of the more salient points are these: Man is constructed on the same general model as the other mammals. Bone for bone, he corresponds with the monkey, the bat, the seal. Every chief fissure and fold of his brain corresponds to the brain of the orang-outang. His blood and tissues are the same, and likewise his diseases. The fondness of certain monkeys for tobacco and for ardent spirits is certainly suggestive of their kinship with humanity-or does the lesson read the other way? For objectors 
there is the fact that a certain monkey, after getting badly drunk, and having an outrageous headache, would never again touch the liquor that occasioned his discomfiture. The processes of reproduction, the differences of male and female, closely correspond in man and other mammals. The argument from embryology I have detailed already. By itself it ought to be conclusive to any candid mind. The existence of certain rudimentary parts and organs in man I have also mentioned incidentally already. These rudimentary parts and organs are considerably many. The coccygeal bone is the most significant. "Thereby hangs a tail," late in the pre-natal period. A comparison of the mental powers of man with those of the lower animals is confirmatory of his relationship with them. Even his moral qualities are anticipated in some slight degree by them. They are capable of jealousy, of fear, of love, of emulation, of shame, of pride, of magnanimity - as when a great dog scorns the snarling of a little one. The moral sense has its beginnings in the social tendencies of the lower animals. The more social instincts are selected and made permanent because they are for the good of those who cherish them.

Endeavoring to trace the genealogy of man, Darwin declares his next of kin to be the catarrhine or Old World monkeys. But we must not, he says, fall into the error of supposing that the early progenitor of the whole Simian stock, including Man, was identical with, or even closely resembled, any existing ape or monkey. The five great vertebrate classes,-mammals, birds, reptiles, amphibians, and fishes, - are all, says Darwin, descended from some one prototype,-probably, as fishes are the most lowly organized, from some very ancient and fish-like animal akin to and nearly resembling our present ascidians, a class of invertebrate, hermaphrodite, marine creatures permanently attached to a support. It is contended that the original group diverged into two great branches - "the one retrograding in development and producing the present class of ascidians, the other rising to the crown and summit of the animal kingdom."

The volumes that contained the chapters on the "Descent of Man" also contained five or six hundred pages on sexual selection - an expansion of two or three pages in the "Origin of Species." "Of all that Darwin wrote, these five or six hundred pages are the most delightful reading. But at the time of their appearance their interest was not a little 
obscured by the intenser interest of the adjacent matter. 'There was another outburst of odium theologicum almost as vehement as that which was occasioned by the book of 1859 . But the vehemence of the odium scientificum was considerably less than then. And it was very noticeable that annong those who cried ont against Darwin in 1872 there were few, if any, of the leading men of science. The six years that had elapsed since he had said to Haeckel that he should not live to see the triumph of his principles had synchronized with an immense advance of scientific thought in the direction of that triumph. In America the personal charm of Agassiz could not defend his pupils from the force of Darwin's argument, and almost to a man they had accepted his conclusions. In Germany the greatest were the first to give in their adhesion. Where such a giant as Johannes Müller led the way, it was entirely safe for lesser men to follow. England, if not so quick as Germany to recognize that a greater than Newton was here, was still not slow, considering the prejudices that she had to conquer. The tide of victory rolled on with steadily increasing force and volume as the years went by, and when, in 1880, Huxley lectured on "The Coming of Age of the "Origin of Species," he could say with perfect confidence: "Those who have watched the progress of science within the last ten years will bear me out to the full when I assert that there is no field of biological inquiry in which the influence of the 'Origin of Species' is not traceable ; the foremost men of science in every country are either avowed champions of its leading doctrines or at any rate abstain from opposing them; a host of young and ardent investigators seek for and find inspiration in Mr. Darwin's great work; and the general doctrine of Evolution, to one side of which it gives expression, finds in the phenomena of biology a firm base of operations whence it may conduct its conquest of the whole realm of nature."

In the history of thought there is nothing more remarkable than the speedy trimmph of a doctrine rumning so strongly counter to the prejudices of mankind in favor of a mechanic-God and so offensive to their amour propre through its assertion of their community of life with lower and the lowest animal forms. How are we to account for such a victory? Largely by the intrinsic rationality of the doctrine taught. Next by the overwhelming mass of evidence which Darwin brought to its elucidation. Last, but rot least, by 
the general temper and spirit of the man, his simplicity and modesty, his gentleness and forbearance, his abstinence from all contention, his evident desire to know the truth, whatever it might be. As time went on, these qualities made themselves felt. They went on before his thought, and by them every valley was exalted and every mountain and hill were made low, and the crooked was made straight, and the rough places plain, so that his thought might make an unobstructed progress through the world and all flesh might see it together. Never, I think, since Jesus spoke the words, "MIy judgment is just because I seek not mine own will," has any thinker had so good a right to take them to himself as Charles Darwin. So little did he care for triumph that in the "Origin of Species" he heaped up every objection he could find against his theory, so that objectors could say nothing against it which he had not said already.

He died on the 19th of April, 1882 - a great historic anniversary, an anniversary of freedom, and well suited, therefore, for the consummation of a life whose motto ever was, "The truth shall make you free." They buried him in Westminster Abbey (where I have stood above his dust, with Newton's close at hand), as if to make the soul of Stanley glad. What a sign was here of the completeness of his victory! It was such a little while since he had been anathematized and hissed and scorned and slandered and reviled as an infidel and atheist, an enemy of Christianity and of religion, and now the nation's grandest temple of religion opened its gates and lifted up its everlasting doors and bade the king of science to come in.

\section{"Far in front the cross stands ready, And the clustering fagots burn, While the hooting mob of yesterday With silent awe return \\ To glean up the scattered ashes \\ Into history's golden urn."}

It was indeed "the hooting mob of yesterday." They do not often come so quickly back. "His body is buried in peace," the anthem softly sang, and then rolled, in thunder, "But his name liveth forevermore."

The life of Darwin was a singularly fortunate and happy one. His outward circumstances were in perfect keeping with his inward disposition. They afforded him the amplest opportunity for beholding the bright countenance of truth 
in the quiet and still air of delightful studies! The only serious deduction was a recurrent and protracted nausea, by which a man of ordinary will would have been remanded to a life of useless idleness. An ample fortune left him free from all professional and business cares and anxieties, and permitted him to give himself up entirely to the pursuit of scientific fact and law. When Haeckel visited him in 1866, he found him in the pleasant home that shielded him for forty years, and near at hand the little garden where the earthworms were working out his problems and the climbing plants were intertwining with his thought. Both porch and house were ivy-clad, and there were overarching and embowering elms. The man himself was tall, broadshouldered, stooping a little as beneath the Atlas-weight of his world-sphering brain. Clear, kindly eyes looked out from under the deep-furrowed brow, and through his silvery beard a quiet, gentle voice made pleasant welcome for the pilgrim to his happy shrine.

Darwin was not one of those who cannot see the forest for the trees, who,

"Viewing all things intermittently, In disconnection dull and spiritless Break down all grandeur."

The parts did not obscure for him the whole. He did not murder to dissect. The healthy vision of the natural man enjoyed the lovely synthesis of outward things, unspoiled by any peeping or analysis that was essential to his scientific search. A worshiper he must have been, and was,a wonderer, for it is truly written, "The more thou searchest the more thou shalt wonder." In the popular theology he made no investment. He came of Unitarian stock, and he went forward and not backward from his inherited opinions. His favorite religious journal was our own Boston Index. He wrote with perfect frankness, over his own name, "I do not believe that any revelation has ever been made." Since it became certain that his doctrine was to become established science, the orthodox have done their best to capture him. But they have only had their labor for their pains.

"The moral must be the measure of health," says Emerson ; and by this measure Darwin can be safely tried. "Acute as were his reasoning powers," said Huxley, "vast as was his knowledge, marvelous as was his tenacious industry, un- 
der physical difficulties which would have converted nine men out of ten into aimless invalids, it was not these qualities, great as they were, which impressed those who were admitted to his intimacy with involuntary veneration, but a certain intense and almost passionate honesty by which all his thoughts and actions were irradiated as by a central fire."

How does the thought of Darwin stand related to our faith in human nature and in God? This is a secondary question. First we must ask if it is true ; and if it is, however it may stand related to our faith in God or in human nature, we must adjust ourselves to it as best we can. But the question, Is it true? has been already asked, and the world of scientific thinkers and explorers to-day, with hardly a dissenting voice, agrees that it is so. And, being so, how does it stand related to our faith in human nature and in God?

To our faith in human nature. How fares it with that dignity of which Channing spoke so well ? It is strange that the defenders of the popular religion should think themselves entitled to attack it on this ground. Yes, it is passing strange! For what Darwin called the descent of man is surely an ascent. And what an ascent from the invertebrate amphioxus to the Darwin who can read the riddle of this mighty evolution! And over against this ascent the popular religion sets the Fall of Man - a fall which left the descendants of the perfect Adam a race of intellectual and moral idiots, in their flesh dwelling no good thing. I prefer to this the Darwinian doctrine of the Rise of Man. I prefer it every way. It is not only a glorious history, but it is also a glorious prophecy. The way that we have come hints at the way we are to go. The force of natural selection is still operative in the world. And it is reinforced by the conscious and deliberate selection of the human mind. Let the good work go on, and when the race has marched as far beyond its present camping-ground as this is distant from the ascidian prototype millions of years behind us, may it be granted us to see, unblinded, from some height of heaven, what a piece of work is man. And what a piece of work he is to-day! By the grace of God I am what I am, I care not by what means. Such as are good enough for the Eternal Power are good enough for me, while in my heart arise 
"August anticipations, symbols, types, Of a dim splendor ever on before

In that unending cycle run by life."

How stands the thought of Darwin related to our faith in God? 'Truly, it is destructive of many things which have been taught concerning him. It is conclusive that he is not altogether such an one as ourselves; that his thoughts are not as our thoughts, nor his ways as our ways; that he is no mechanic-God, no Creator in the traditional sense. What then? Is he something less than heretofore he has been deemed? something less great, less wonderful, less sublime, less worshipful? My friends, it is not so. The vastness and the wonder, the sublimity and the worship, in the new thought, are not less than in the old, but infinitely more.

"For' we have learned

To look on Nature not as in the hour

Of thoughtless youth.

We have felt

A presence that disturbs us with the joy

Of elevated thoughts, a sense sublime

Of something far more subtly interfused,

Whose dwelling is the light of setting suns, And the round ocean, and the living air, And the blue sky, and in the mind of man : A motion and a spirit that impels

All thinking things, all objects of all thought, And rolls through all things."

This Presence, Motion, Spirit, is our God. O God, our God, how excellent is thy name in all the earth! 


\section{DARWIN.}

[Read on the oceasion of the preceding Lecture, by Mr. CindiLEs T. CatLis, with the permission of the Author.]

HE was a bold discoverer of the wise And lucid order of the world, who bade

Men love the truth and speak it, and be glad

when each ideal of superstition dies.

The bigot cursed him, and, with flaming eyes,

Flashed hate upon him as one gone mad

With stark God-enmity, although he had

No blacker sin than honest hearts devise.

He was a hero for the right of men

To seek beyond their bibles, churches, creeds, Beyond the tyrannous will of pope or priest,

Thought buried deep in nature; holy when

Revealed to us by any soul that reads

The infinite mind in God and man and beast.

$\Lambda$ mid the harsh endeavors of old days

IIe strove supremely, and, with patient will,

Climbed masterfully onward, upward, till

He rose above men's bitter blame, or praise.

He probed our life aloug its secret ways;

Back through historic centuries, farther still, He traced the simple, clear designs which fill Creation, as they fill a robin's lays.

Amid the vast complexity of forms Births from one primal ancestry he saw, Like stars and planets from one chaos hurled,

And showed, through æons of fire and flood and storms, The march of evolution and of law, The beauty and the wonder of the world. 
Ah, we could only listen when he told How, through the antique ages to the new, Life from a barbarous toil and struggle grew, Like a staunch creeper from an arid mold -

How savage instinct in the strong and bold Crushed out the weak, and how the mightier few Roamed in their wild blood-thirstiness and slew The fierce-fanged slayers that were Kings of old.

He pictured to our eyes the carnal strife, The eternal woe and pathos of the earth, And awful brooding death that makes us mute-

And thus he spoke the story of our life, The growth of mind from some tenebrious birth, The soul of man developed from the brute.

Since he has been, omr craving thought has gained Fresh wings and ampler airs; his valor broke A slavery which had meekly worn its yoke, A fear which rose to courage as it waned;

He shaped the years he lived in and attained The leadership of people; he awoke A dream of freedom with each measured stroke Cut at the shackles which had held us chained.

Through him the science of the age became A thing so near to every yearning heart, So full of what the future man shall know,

That in our nineteenth century his proud name Glows beacon-wise before us - is a part Of all that song and wisdom can bestow.

Yes, wilder, sweeter than the music sung By any lute-voice in this age of ours, Sweeter than old child-fancy when it flowers In trembling beauty on a poet's tongue,

Was that new cry within us when he flung His thought to men-that precious thought which dowers Life with a deeper sense of deathless powers, Hope with the faith that it is ever young. 
He lifted darkness from the face of time

And from the face of nature: we to-day,

Seeing with his sight, foretell a song shall rise

Out of his spirit of truth - a song sublime

As the wind's harmony heard far-away

Where the sea-surgings seem to meet the skies.

George Edgar Montgomery.

\section{ABSTRACT OF THE DISCUSSION.}

\section{Mr. William H. Boughto: :-}

Mr. Boughton, in opening the debate, said: that so much had been written and said, and well written and well said, respectingMr. Darwin's work and the almost ideal beauty of his character, that nothing remained for presentation, comment or eulogy. 'The use, however, of certain side-lights might bring out some aspects which may not have received due attention, notably in this, that $\mathrm{Mr}$. Darwin's mental greatness rests quite as much upon what he consciously, deliberately refrained from doing as upon that which he did. Consciously, because it is incredible to think that he was not alive to the questions upon which all eyes in his day were centered, such as force, matter, motion, cause, and especially first cause. Deliberately, because he clid not yield to the temptation of even discussing these questions. His grand conclusion was Natural Selection. There he stopped, and he did not imperil its grandeur by any such formula as, "Given Natural Selection, therefore the Unknowable." He must have heard, as the rest of his generation did, all about a First Cause, and its equivalent, a Power from which all things proceed.

These were burning questions then, glowing with the heat of their formative phases. But Mr. Darwin refused to make his Natural Selection or anything else proceed from Cause or Power. His instinct was too alert, his intellect too keen, not to have noted (1) that all we know of Cause is antecedence, (2) that among the things which we do not know about the Unknowable is that the knowable proceeds from it. Granting that, by reason of the relativity of thought, we are obliged to postulate some unknown force as the correlative of the known force, there is no system of 
logic which compels the conclusion that either proceeds from the other; and this is more clearly brought out by the fact (3) that we camnot think or try to think outside of that definition of Space, knowable and unknowable, which describes it as the abstract of all co-existences; and if this is so, then matter, motion, time, force, cause, power, proximate and ultimate, if existences at all, are $c o$-existences without the possibility of either proceeding from the others or from any other. (4) It is well for us to remember right here, and all the time, that matter, however conceived and however defined, is indestructible; and that if, as has been said, our conception of matter is that of co-existent positions which offer resistance (and anything which offers resistance has something more than position), then space is simply an extension or attribute of matter, and would offer resistance if near enough to be touched by any of the physical or mental senses. Space is matter; and it is matter, or substance, knowable and unknowable, which is the abstract of all existences; and their co-existence prevents procession and throws out all ideas cf cause and antecedence.

While we may repay the debt which we owe to Darwin for that which he did, we cannot discharge our obligations to him for that which he did not do.

\section{Professor P. H. VAN der Weyde:-}

I have two matters of interest to which I desire to call the attention of the members of the Association. A few years ago, on the occasion of the establishment of the Imperial University at Tokio, in Japan, my highly esteemed friend, Professor E. S. Morse, recently President of the American Association for the Advancement of Science, delivered there a series of lectures on Evolution. He informs me that his auditors listened eagerly to the new doctrine, and accepted it much more readily than our people in America and Europe have done, owing to the greater freedom from religious bias and prejuclice which prevails in Japan.

Professor van der Weyde also read a portion of a letter to Darwin from certain Dutch scholars, on the occasion of his sixtyninth birthday. The letter was accompanied by 217 photographs of his admirers in Holland. It alludes to the fact that Dr. J. E. Doornik, a physician of Amsterdam, advocated as early as 1808 and 1816 , in published treatises on natural philosophy, the theory "that the various morlifications in which life was revealed in consecutive times, originated each from the other"; thus preceding Lamarck in advancing evolutionary views. His arguments attract- 
ed but little public attention at the time ; but in 1849, on the oceasion of the translation of the "Vestiges of the Natural History of Creation," by Dr. T. H. van der Brok, professor of Chemistry at the military medical college in Utrecht, the subject of evolution received a new impetus-Professors G. T. Mulder, F. C. Donders. and P. Harting, among others, recognizing the light which the theory of development throws upon creation. Other eminent scholars, including Professor Emil Selenka, of Leiden, and his successor, Professor C. K. Hoffmann, later gave in their adhesion to the doctrine, which, Professor van der Weyde says, is now generally accepted among scientific scholars, and the liberal think ers of the Reformed Church, in the Netherlands.

Darwin replied briefly and cordially to the letter of the Dutch savants, expressing his obligation for the interesting history container in it, all of which was quite new to him. 



\section{SOLAR AND PLANETARY EVOLUTION.}

BY

GARRETT P. SERVISS

Author of "Astronomi with ax Opera Glass," etc. 


\section{COLLATERAL READINGS SUGGESTED}

IN CONNECTION WTTH ESSAY III.

Spencer's First Principles, and Illustrations of Universal Progress; Haeckel's History of Creation; Kant's Critique of Pure Reason; Laplace's Mécanique Céleste; Graham's Creed of Science; Clodd's Story of Creation, and Childhood of the World; Picton's Iystery of Matter; Mivart's Contemporary Evolution; Winchell's Norld Life; Gladstone's Juventus Mundi; Slaughter's Modern Genesis; Newcomb's Astronomy; Stewart and Tait's Unseen Universe; Jevons' Principles of Science; Tyndall's Fragments of Phys. ical Science; Proctor's Other Worlds than Ours (chapter IX). 


\section{SOLAR AND PLANETARY EVOLUTION.**}

Everything of which we have any knowledge is the result of growth or progress, in one way or another, according to law. I suppose that no reasonable person, who is acquainted with the facts, wonld pretend that the earth or the universe is any less the result of a regular process of development than a tree.

The question before us is, How did the world begin? How were the heavens framed? Any answer that may be made to this question must take into account what, broadly speaking, may be termed the nebular theory. But we need not confine ourselves to the consideration of the theory of Laplace. I speak just now of a nebulous beginning in a general sense, without special reference to any particular hypothesis. What we want to get, first of all, is a clear conception of how the solid earth, the sun, and all the substantial bodies by which we are surrounded, were once nebulous masses, as thin as air.

Perhaps we can best get at it in this way. Suppose we could take a puff of steam just as it came from the boiler, and remove it, freed from all external influences, into space. What would happen? At first, perhaps, owing to its great heat, the steam would be invisible. But the intense cold of surrounding space would cause it to radiate its heat, and it would condense until it became visible as a cloud of vapor. The two great constructive forces of the universe, heat and gravitation, would carry on a contest in the little puff of steam; heat pushing outward, gravitation drawing inward. But gravitation is the more persistent force, and as the heat.

\footnotetext{
* Synopsis, from stenographer's notes, corrected by the lecturer. CoprRIGHT, 1889, by The New Ideal Publishing Company.

The tlianks of the Publishers, and of the Brooklyn Ethical Association, are due to Messrs. D. Appleton \& Company for the nse of the illustrations on pages $59,63,64,65,66,68$ and 69.

The cuts illustra ting Laplace's theory and Faye's hypothesis were kindly furnished by Mr. Serviss - the former having been devised by Professor Feorge W. Coakley, for his lecture on "The Nebular Hypothesis of Laplace," read before the American Astronomical Society.
} 
leaked away gravitation would draw together the particles of vapor until a drop of water was formed, and so from invisible vapor our puff of steam would have become a visible liquid. Behold a miracle! Yet the explanation is simple.

As the process of cooling continued, the drop of water vould become a substance of yet a different order, for there would still be some heat left in the water, and this would

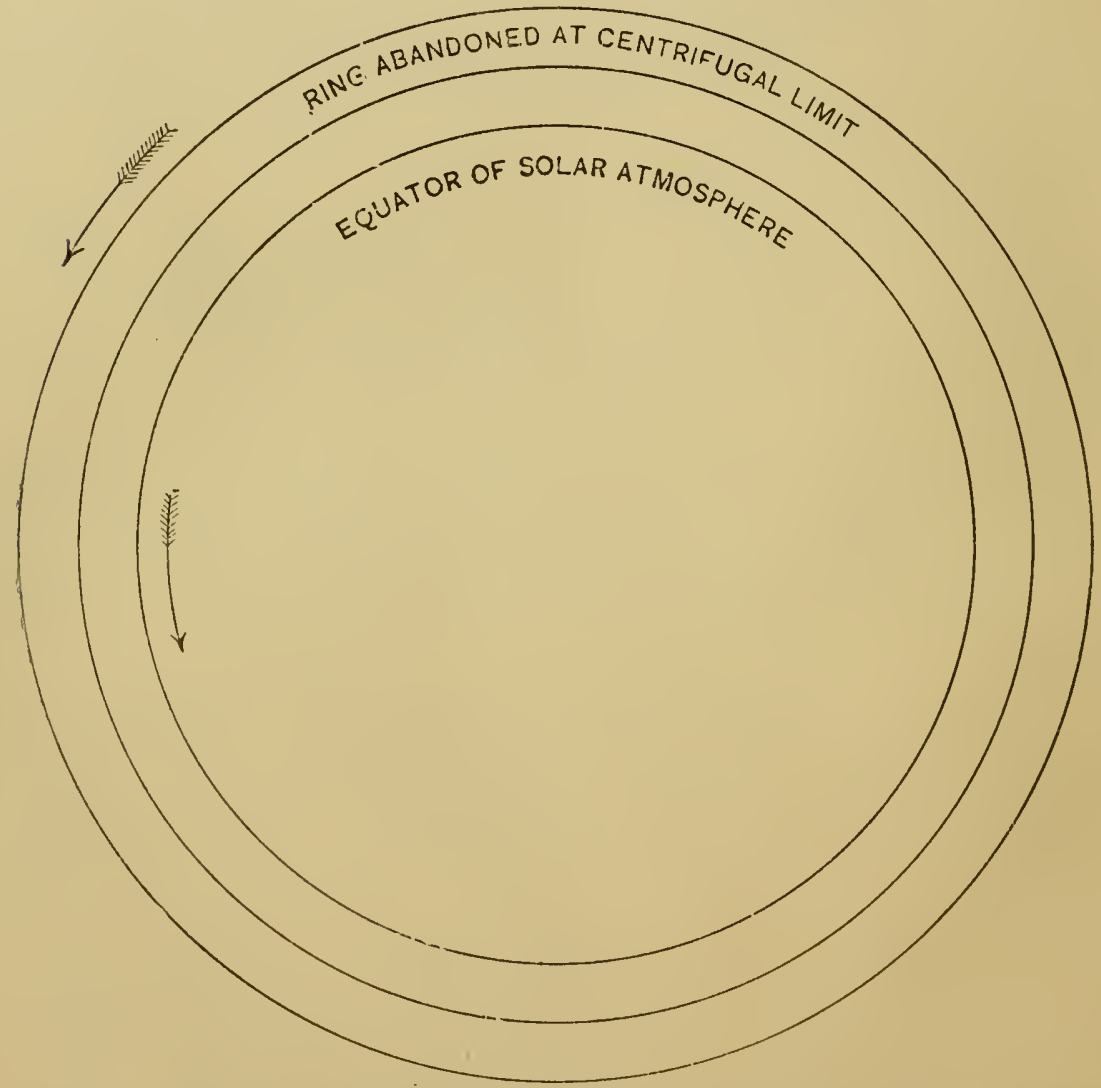

Nig. 1,-representing the equator of the solar atmosphere after it has abanaoned a ring at the centrifugal limit, according to Laplace's theory.

continue to escape into space, until finally, when the freezing point was reached, the drop of water, through the action of crystallization, would turn into a ball of ice. We should thus see a puff of steam change from an invisible gas to a vapor, from a vapor to a liquid, and from a liquid to a solid body, and all through the simple process of cooling.

The creation of a world is just as simple as that. Heat 
and gravitation, those arch-mechanics, which without the aid of saw or hammer have builded the universe, contended for mastery in the evolution of the earth just as they did in our puff of steam. Gravitation has always prevailed in the end, because gravitation cannot leak away like heat. The earth was first a nebula - perhaps an invisible gas - then in the state of a liquid, and finally it became, as we see it, solid, cool and habitable. It is only a question of the

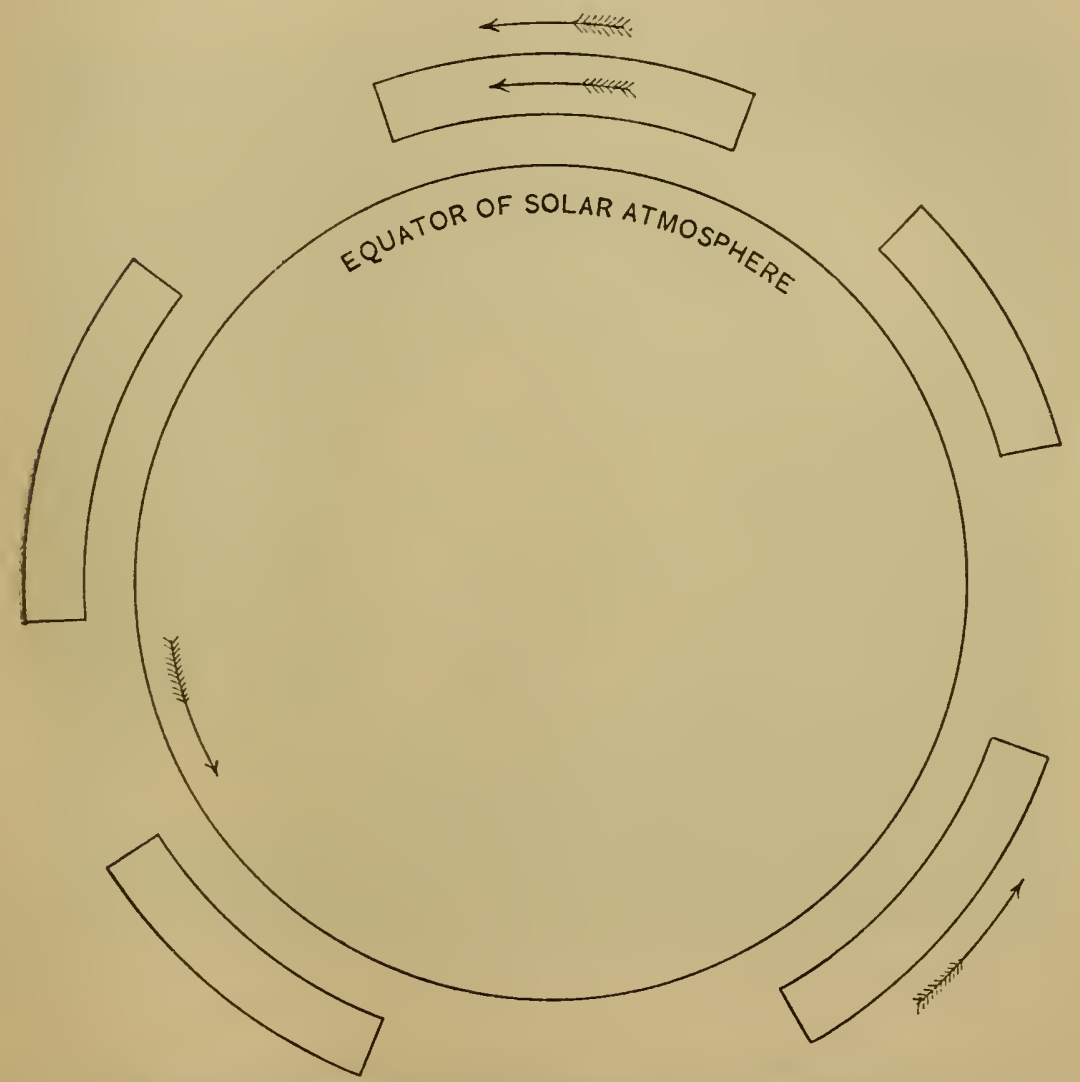

Fig. 2,-representing the ring broken into several segments.

amount and intensity of heat. Given heat enough and it would be as easy to turn the earth into a nebulous clond as to melt a snow-flake.

Laplace gives us one hypothesis of the origin of the solar system, which I will endeavor to illustrate. (At this point the lights in the church were extinguished, and a picture of a revolving nebula was thrown upon the screen, 
which was made to throw off concentric rings of nebulous matter. 'These rings being thimner at some point than elsewhere, broke at the thinnest place, condensed into oblate spheroids, and, with continued rotation, into spheres. See Figures 1, 2 and 3, pages 56,57 and 58.) The rotating nebulous mass contracts by loss of heat; and, accorr-

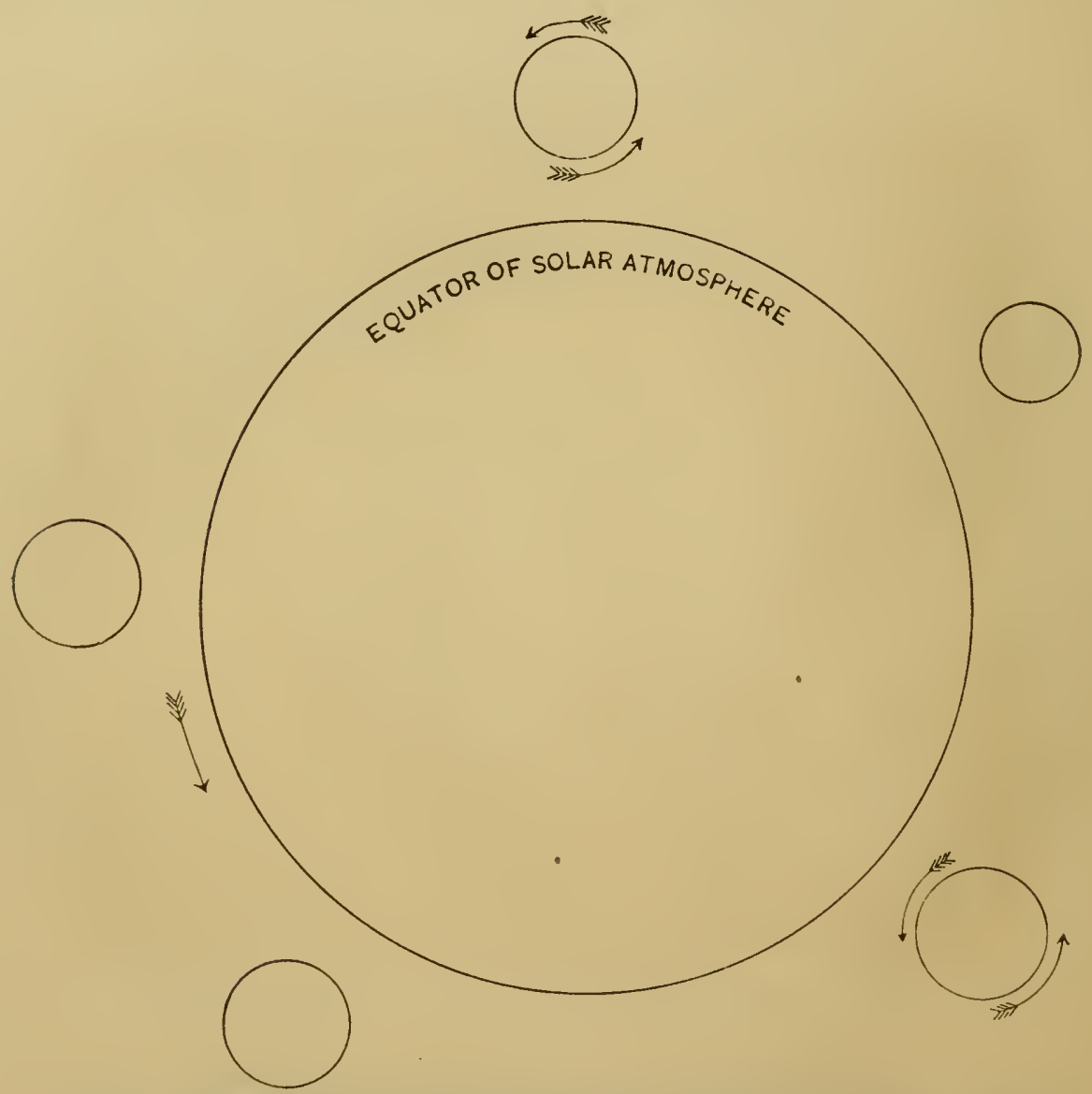

Fig. 3.- representing the fragments of the ring, as shown in Fig. 2, gathered up into spherical form by the nutual attraction of their molecules. It will be seen that the spheres must naturally revolve around the solar equator in the same direction that it moves, and also rotate on their axes in the same direction. Movingin nearly the same orbit, they would next be gathered into a single sphere, moving around the sun in the same direction, but with eccentricities dependent upon the force and directions of their collisions at the time of their uniting.

ing to a well-known law, as it contracts its velocity of rotation increases. When the centrifugal and centripetal forces at the equator of the mass balance one another a ring 
of matter separates off and is left suspended around the contracting nucleus. Other rings form in the same way, until a series of them surrounds the central mass which has contracted into a sphere. But these rings are not everywhere of equal thickness, and the tendency of their constituent particles to gravitate toward the thickest part causes them to separate at the thinnest point, and finally to form oblate spheroids of nebulous matter, which ultimately condense into spheres.

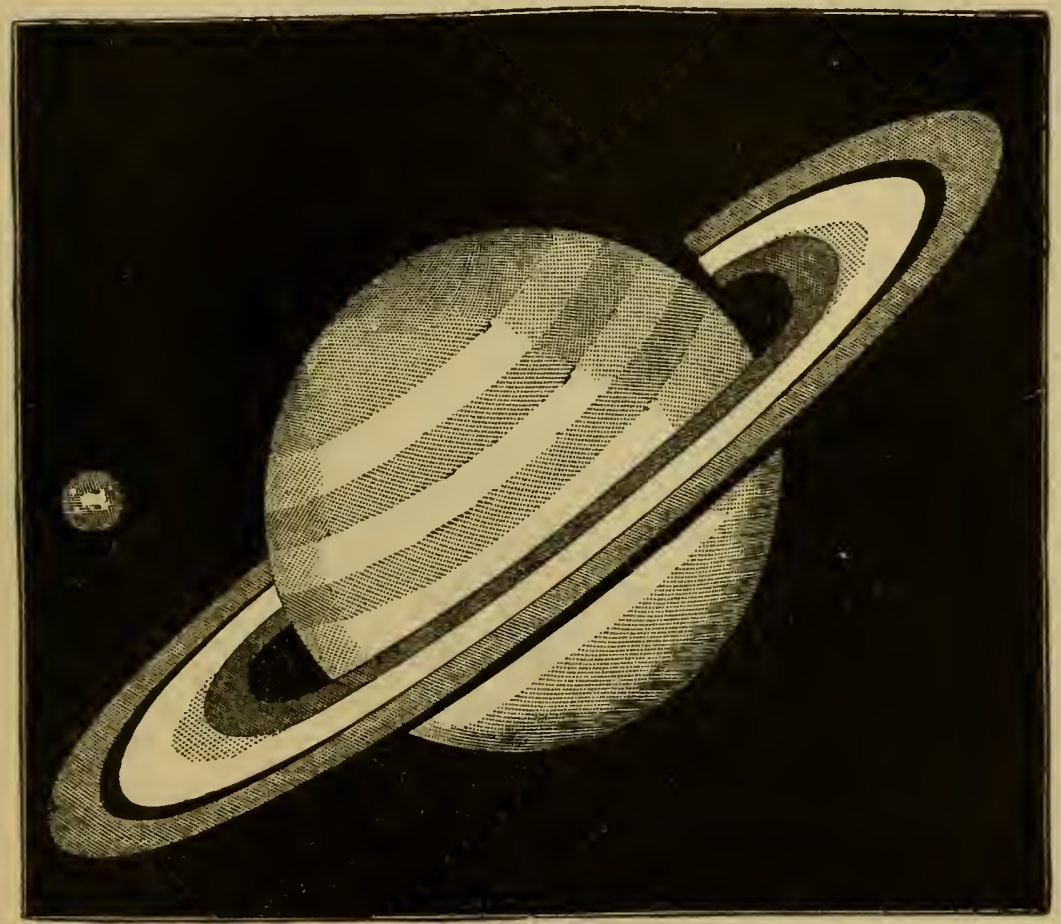

Fig. 4. The planet Saturn, showing rings, and size as compared with the earth.

Let us illustrate this by supposing that we have a grindstone, on which, while rotating, we pour a film of water. If we revolve it fast enough the water will fly off, but we may revolve it just fast enough to cause the centrifugal and centripetal forces to balance. Then if we could make the stone contract in size, the layer of water would be left suspended in the air as a ring surrounding the revolving grindstone. In the case of the revolving nebula, the contraction of the imner sphere of nebulous matter assists in the separation of 
the surrounding ring. The spheres formed from the rings would in turn throw off additional rings to form satellites.

Now, if we look at the solar system, we discover in its character and movements strong confirmation of this hypothesis. We find there just what would naturally occur were this theory a correct one. Each planet revolves around the central orb at its own speed and in its own distinct orbit, and in a direction in common with the rotation of the original nebulous mass. The nebular theory constitutes therefore a conclusive and nearly satisfactory explanation of the way in which those great demiurgic forces, heat and grav-

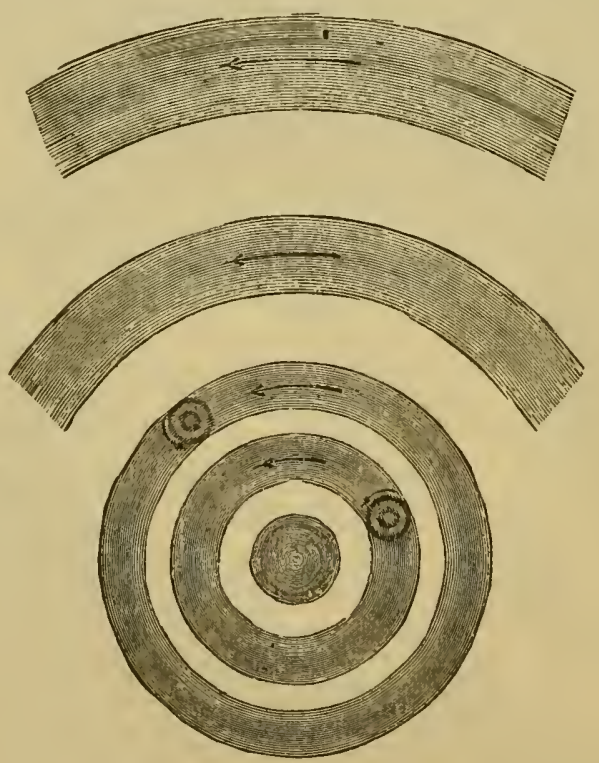

Fig. 5.

itation, have wrought out the results we see. In the planet Saturn we have an example, patent to any observer, of the probable truth of the nebular theory. (A representation of the planet was thrown upon the screen. See Fig. 4, page 59.) 'Through any telescope, even of moderate power', we may see that this planet is surrounded by rings, which, being nearly equal in density, have not been broken up into satellites by the unequal attraction of their various parts. Though these rings seem solid and uniform through the telescope, it is reasonably certain that they are composed of many small bodies, rotating in the same plane, and so presenting the appearance of a flat surface. 
Now, certain objections have been made to the nebular theory, the most important of which is based upon the direction of the rotation of the two outermost planets and their satellites. The satellites of the inner series of planets, from Mercury to Saturn, inclusive, revolve as the planets do, from west to east. Those of Uranus, however, revolve nearly at

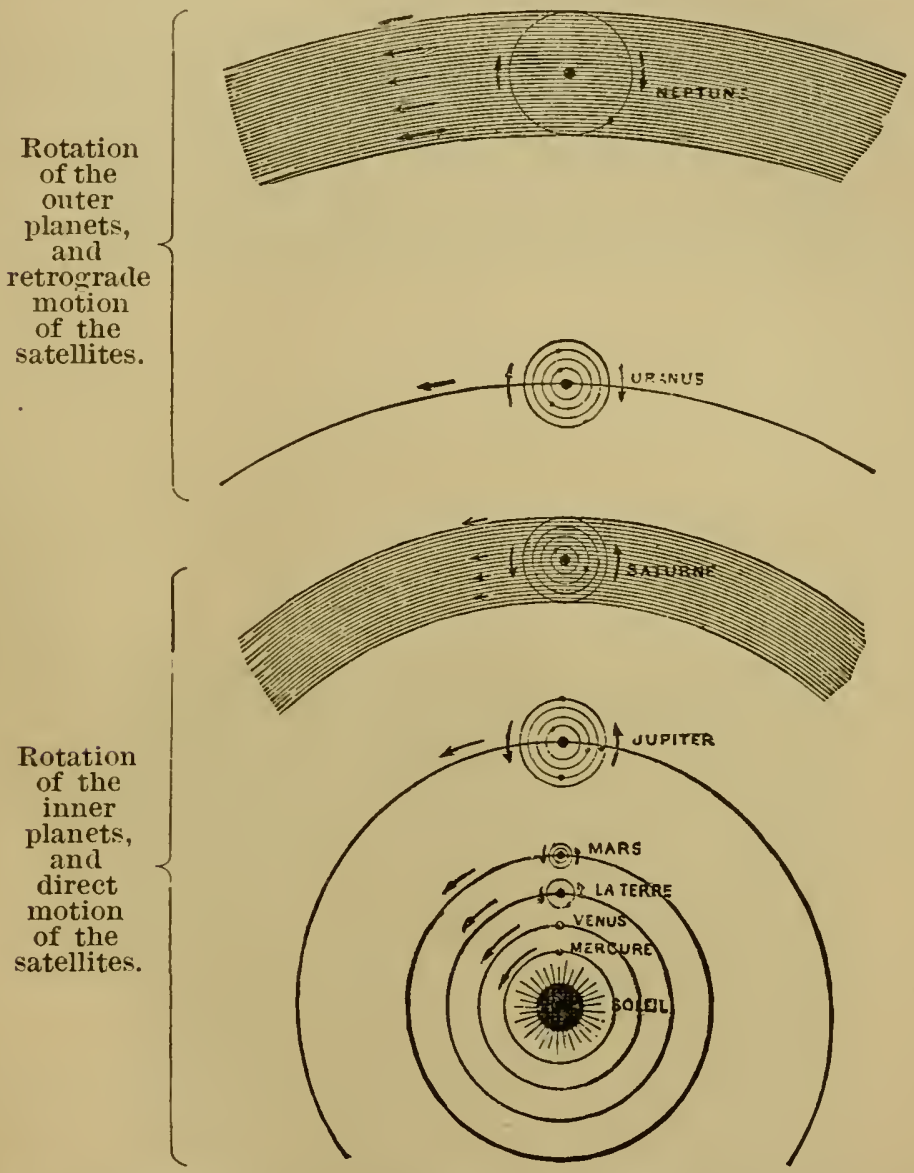

Fig. 6. Motion of planets and satellites if formed simultaneously, as by Faye's hypothesis.

right angles with the plane of rotation of the planet, while those of Neptune revolve in a reverse direction. This would at first appear to be a serious objection to the theory; but recently the French astronomer, Faye, has propounded an hypothesis which explains this apparent anomaly. (See Figures 5 and 6 , above and on the opposite page.) Faye's 
explanation rejects the theory of Laplace in part, and goes back to that of Descartes, which assumes that the planetary rings were produced by a vortical or whirlpool motion of the original nebulous matter, and nearly simultaneously, instead of by the successive separation of concentric rings. Supposing that the entire mass from which the planets are formed revolves in one general direction as a whole, like a grindstone or wheel, it is evident that the outer edge of the mass would rotate much faster than the inner portions. This would also be true of a vortical ring formed within the mass, and, when that ring broke up, as its outer edge would tend to move faster than its inner edge this tendency would be impressed upon the resulting spheroid, which consequently would rotate on its axis in the same direction in which it moved around the sun. In this way, M. Faye thinks, the inner planets received their impulse of rotation from west to east. But before the rings of Neptune and Uranus (being formed somewhat later than the others) condensed into planets, the sun had attracted to itself nearly all the matter not already formed into planets, and the rings, being thus left separate, began to revolve, not as if they all formed parts of one disk, but independently. Thereupon their velocity varied inversely as their distance from the sun, their outer edges tended to move more slowly than their inner edges, and consequently the planets formed from them rotated in the opposite direction to their revolution around the sun. Of course the satellites formed from these planets would revolve around their primaries in the same direction in which the primaries rotated on their axes.

Dr. Karl Bramn, a German philosopher, has suggested another theory of planetary evolution. He assumes that throughout the original mass various centers of condensation were formed, which ultimately became planetary bodies, revolving around the largest centre of condensation of all, which was the sun. All these theories agree in assuming that the original condition of the universe was that of a nebular mass, and that suns and satellites were evolved from it by the action of laws precisely similar to those which we behold still active in this world in which we dwell.

If, now, on looking at the starry heavens through the telescope, we find nebulous masses in the same condition in which we have supposed the sun and the earth to have formerly existed, it will go far to confirm the nebular hypothesis 
of the origin of the solar system. That is precisely what we may observe. (A representation of a nebula in the constellation of Lyra was thrown upon the screen. See Fig-

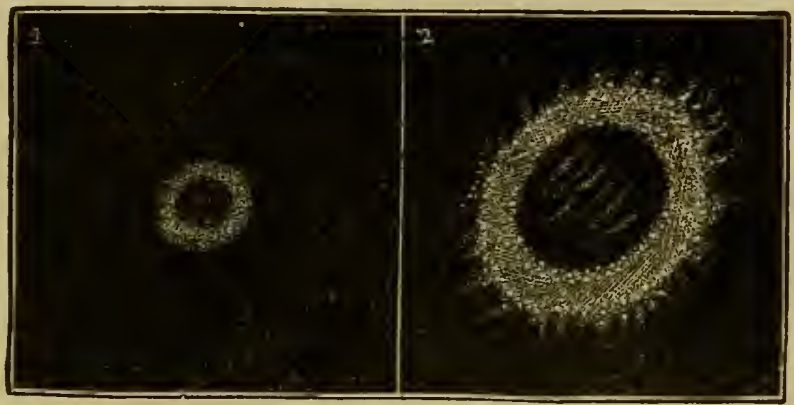

Fig. 7. Two views of the ring nelula in Iyra

ure 7.$)$ If we look at this nebula, we find great rifts in it, and brighter spots in some places, which show that there is greater condensation in certain parts than elsewhere. A nebula in the constellation of Leo (shown upon the screen) shows a marked center of attraction, with evidences of a

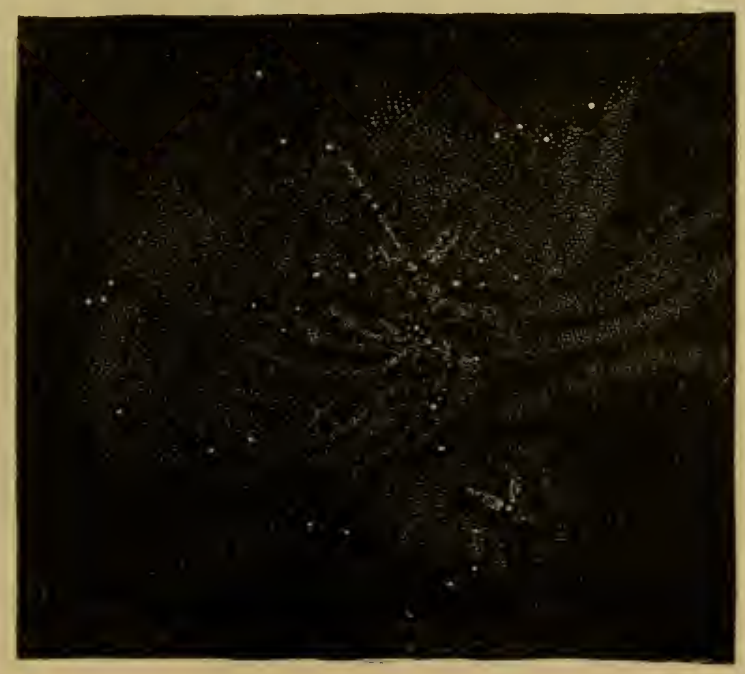

Fig. 8. Yebula in Sword of Orion, showing several points of condensation.

tendency to circular motion. A nebula in Draco (illustrated from a photograph taken by Prof. Holden by the aid of the new Lick telescope, the largest in the world) shows a 
spiral formation of a new order, as if a star had revolved around another star, which was itself in motion, and had left a train of nebulous matter behind it like a comet. (See spiral nebula in Canes, Figure 13, page 69.) A photograph (thrown upon the screen) of a strange nebulous object attached to the star Maia in the Pleiades, is interest-

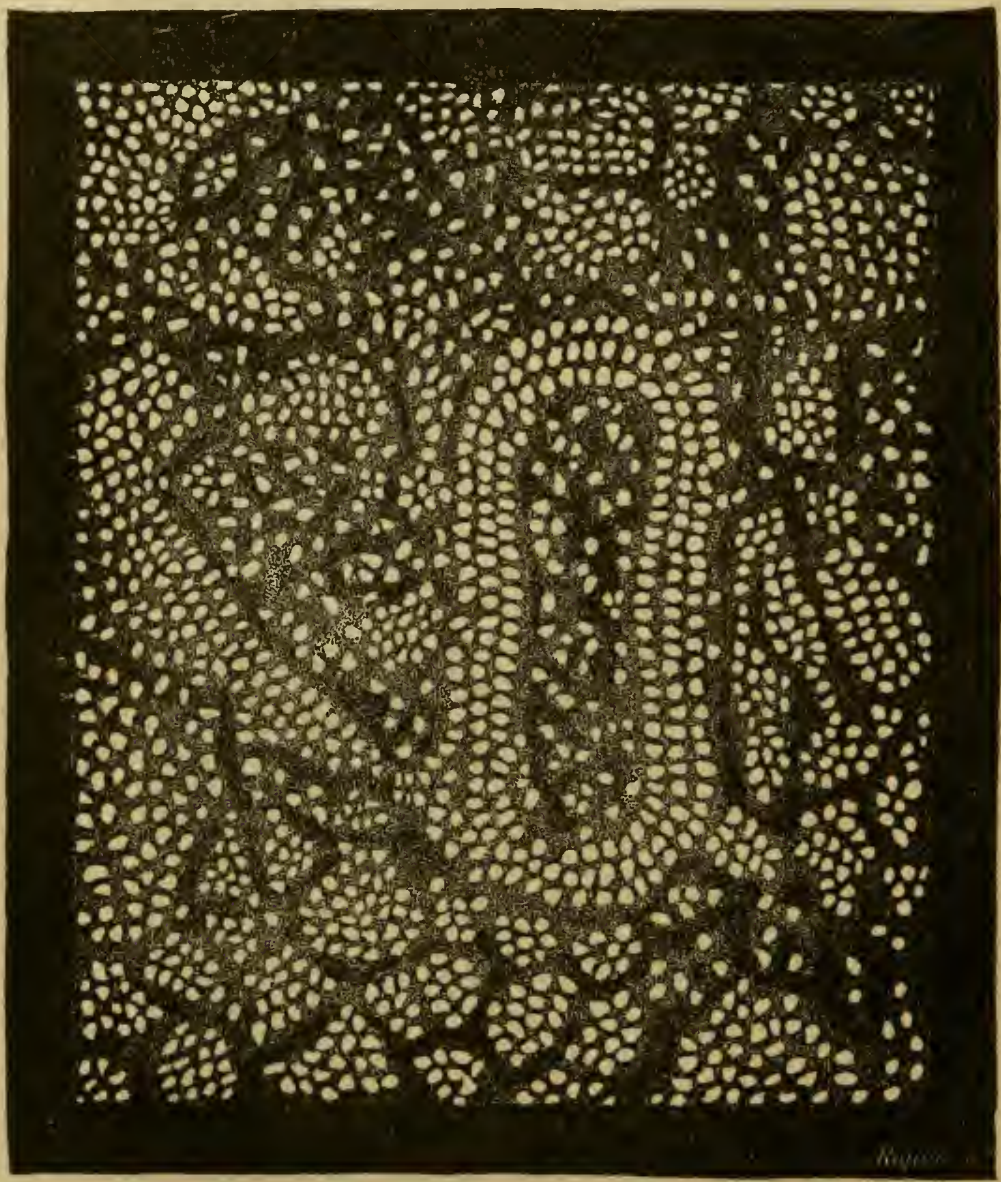

Fig. 9. Surface of the Sun, magnified, showing granular, or "rice-grain" appearance.

ing as being the picture of an object which has never been seen by the eye of man, even by the aid of the most powerful telescope. The plotographic plate is more sensitive than the retina of the human eye. This is an apparent illustration of the hypothesis that all nebulæ may have been 
formed originally from an invisible gas. The great nebula in the sword of Orion (see Figure 8, page 63) shows many points of condensation. From it will be developed a little universe within a greater universe, forming in time not a single sun or star, but a cluster of stars.

We have seen in the nebulæ evidencies of rotation and contraction. Now let us consider the condition of a body after it has passed out of the nebulous into the solid state. (A picture of a portion of the sun's surface is thrown upon. the screen, showing a dark back-ground, mottled with shining spots. See illustration, Figure 9, on page 64,

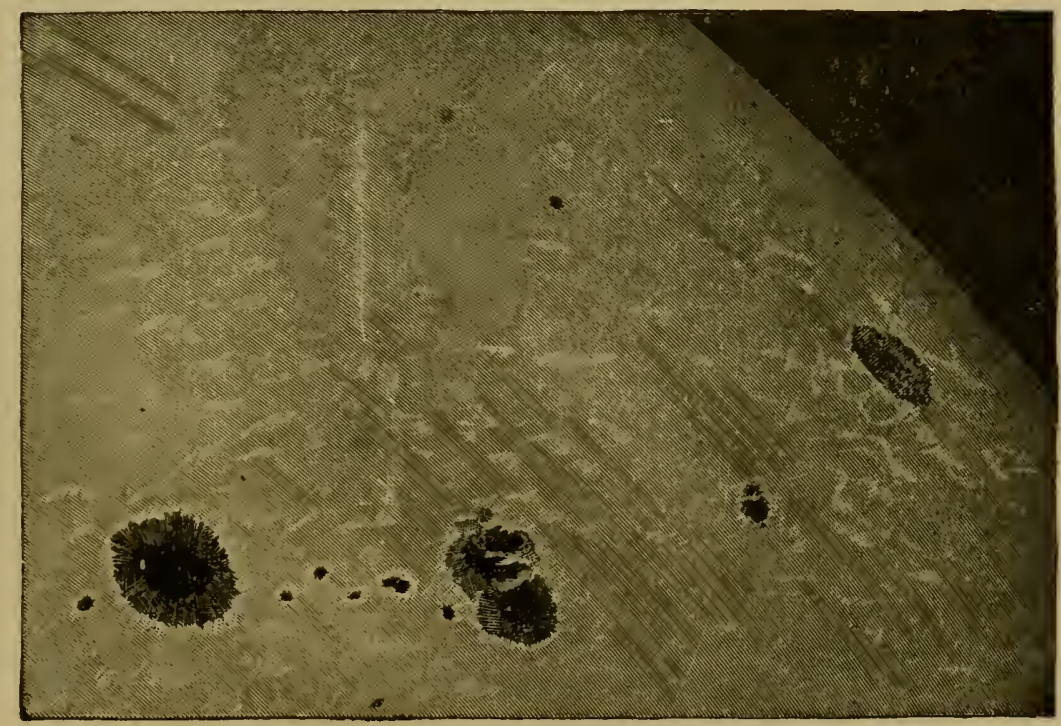

Fig. 10. Section of the Sun's Surface, showing a belt of sun-spots, near the center of the disk.

opposite.) The surface of the sun, of which we shall first speak, is not uniformly clear and shining, but broken up into bright parts interspersed with parts that are less luminous. The shining portions are sometimes called "rice-grains," from their appearance, and seem like clouds of luminous matter. These are the parts of the sun which give light. Sir John Herschel suggested that they might be "living organisms," but they are merely the hotter portions of the solar surface. Among them sometimes appear great rifts or spots (a picture of solar spots is thrown upon the screen) which are never seen at the poles, but always within a cer- 
tain region on either side of the sun's equator ; these regions are like broad bands parallel with the equator. (See Figure 10 , page 65. )

(A photographic picture of the planet Jupiter is thrown on the screen. See illustration, Figure 11, below.) Jupiter, which has only recently passed out of the condition which the sun is now in, shows bands in its cloudy envelope, which cover regions similar to those on the sun where spots appear, and foreshadows what will be the fate of the sum when it shall lose its brilliancy and become dark and dead. Jupiter being smaller than the sun, cooled sooner; but the

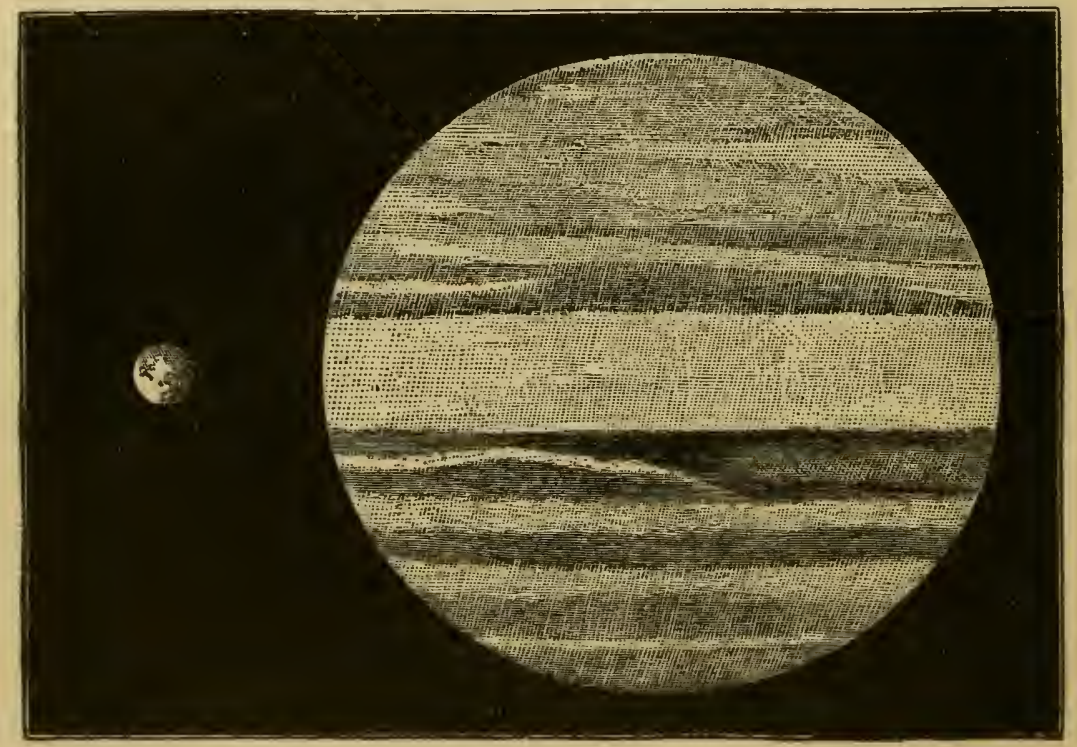

Fig. 11. The planet Jupter, showing belts, and size as compared with the earth.

sun, astronomers tell us, will follow in the same path. The end of all will be that the sun will become a great planet, like Jupiter, but differing from the other planets, as we see them, in that it will have no light to reflect. What a theme for' another Milton! 'This great and generous sun, which lias shed his light without stint on all around him, gilding even the dust of space, shall be robbed and stript of his splendor, and go wandering blindly through the heavens, dragging after him the dead worlds that once basked in his beams.

The earth, as we know it, illustrates the next step in de- 
velopment beyond the condition of Jupiter. Millions of years ago the earth was like Jupiter, and before that, it was a sun, shining by its own light. Ages earlier still, it was in the condition of a nebula. Now, we dwell on the hardened surface of an extinguished star. The earth has passed through all the stages of growth; mountains, plains and ocean-beds have been formed by gradual and entirely natural processes; and at last it has reached the stage in which geological changes are so slow that the tiny coral animals may be ranked among world-builders, as they lay the foundations of future continents. Even in its present condition, the earth is still radiating heat into space. According to Guyot, the earth at the time of the deposition of the lower strata might be likened to a galvanic pile, which radiated streams of electricity into surrounding space. The earth retains the faint reflection of one of its solar features in the auroral lights. These phenomena are of an electrical character. The earth is a great magnet, having its positive and negative poles, and it is near these poles that the auroral lights shine the most brightly. There is an intimate connection between the spots and outbursts which we observe on the sun, and the magnetic condition of the earth.

When we contemplate this fair earth, with its manifold beauties and teeming life, we naturally wish that this was the last stage in its evolution; but science will not let us pause. The earth, astronomy tells us, must die, and become like that dead world, the moon, which forever accompanies it, and shows what this world will sometime be. The most bitter disappointment connected with the improvement of modern telescopes, is the discovery that the moon is a dead world. (A magnified photograph of the moon was shown. See Fig. 12, page 68.) It has vast oceanbeds, but no water; volcanoes, but no fire. There is no grass, no clouds, no atmosphere. In all that dead world there can be no sound; for, without an atmosphere to convey the waves of sound to the ear, though the beetling crags of mountains should topple and fall there would be no noise from the concussion. The moon as seen through the telescope has a certain beauty, but it is the beauty of icicles, not that of a living world.

Light may be thrown upon the question of the formation of the universe, by contemplating its shape or form. Her- 
schel, viewing the Milky-Way as it appears to us in the heavens, conceived of the universe as a flat disk. The conception of the late Mr. R. A. Proctor, however, which may be regarded as his greatest scientific achievement, presents a nore probable idea of the form of the universe. (A pic-

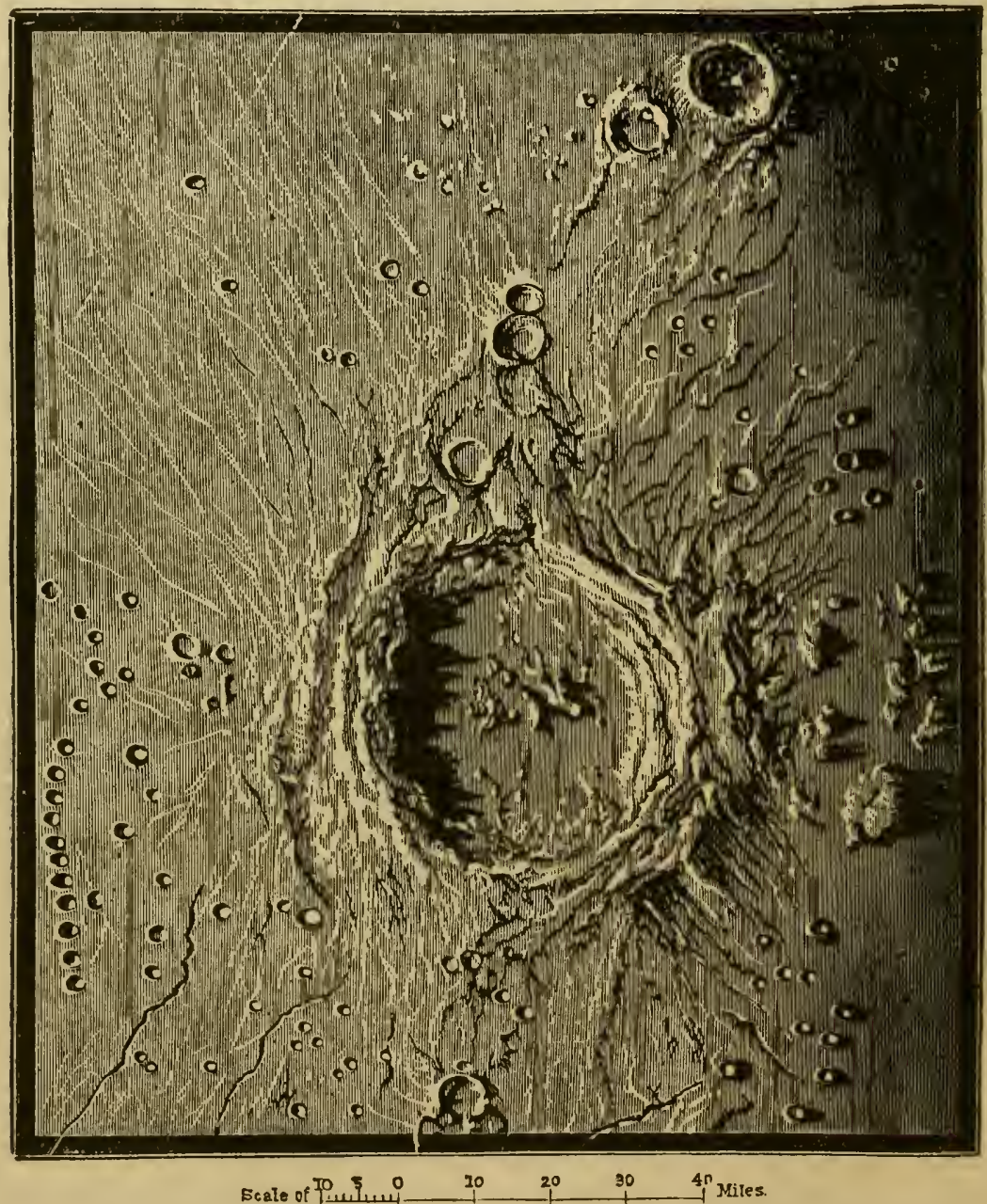

Fig. 12. A portion of the Moon's surface, showing lunar volcano, "Copernicus."

ture illustrative of Mr. Proctor's conception is thrown upon the screen.) Mr. Proctor dissented from Herschel's theory, and regarded the Milky-Way as manifesting a spiral form, sinilar to that exhibited by some of the nebulæ.

Various speculations have been made regarding the ex- 
tent of the universe. Are there an infinite number of worlds, extending beyond our utmost vision? We cannot know. All the objects within the reach of the most powerful telescopes belong to our universe. It is possible that other universes exist beyond, which we are unable to perceive because of the absence of a luminiferous ether, connecting them with our range of vision. It is an interesting question whether our universe is still young and growing, or whether it is now on its downward course, tending to decay and death. Respecting this question it may be said that we find within the range of vision very few dead

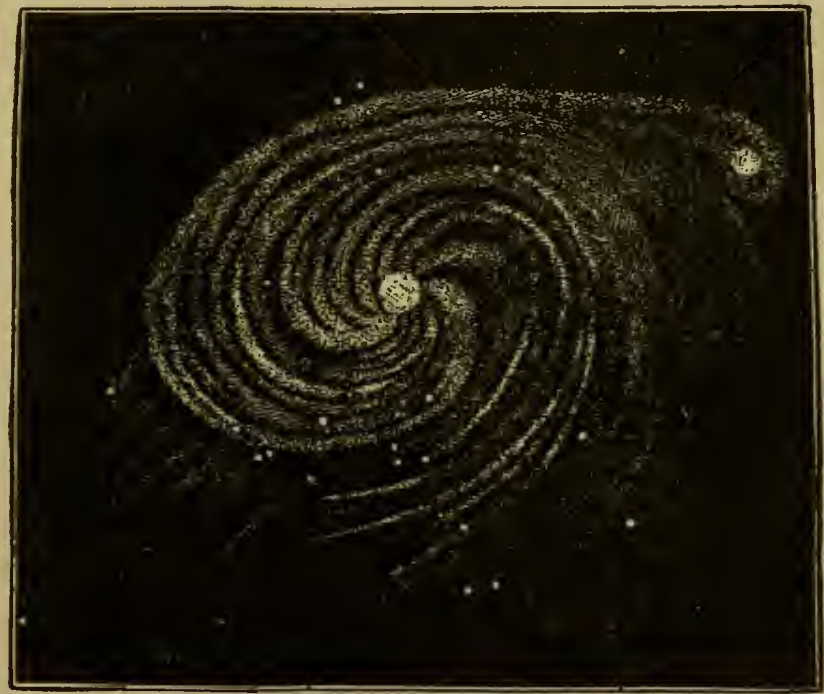

Fig. 13. Spiral nebula in Canes Venatici.

stars, while the number of nebulæ in process of forming into stars is very great. We may therefore assume that the universe is still in a youthful condition and has not passed the noon of its existence. The spectroscope assures us that those stars which shine with a red light are the oldest, and the nearest extinction. Of these there are comparatively few.

We have brought the history of a planet from the period of its primal evolution out of the fiery mist, to its extinction. Is this all? Will there be no resurrection of dead worlds? When a planet like the moon has parted with its heat it will still continue to rotate on its axis and to re- 
volve around its gravitational centre. In this continued motion resides the potency of renewed life. Motion is transferable into heat; and heat calls gravitation into action. If the earth, moving through space at the rate of nearly twenty miles a second, should meet another body of like size and velocity, its mountains would dissolve in fiery mist, its oceans would be turned into vapor, its continents would dissolve in smoke, and the solid earth would melt like wax and disappear in a nebulous clond. The same would be true of an encounter between the sun and another sun possessing equal mass and equal or greater velocity; out of the mebula thus formed, through the process of evolution, a new sun might be formed, and new life ultimately dawn on other' worlds. The stars are shooting in every direction in erratic courses, and such collisions are not impossible. It is reasonably certain, indeed, that they have occurred. New star's have suddenly appeared, and stars of lesser magnitude have blazed up into more magnificent suns.

The charm of the study of creation, where we behold the gleam of millions of suns, and systems on systems, is not in thinking of our own insignificance in the presence of this wonderful universe; for we are small only as we identify ourselves with our little earth. IVe should regard ourselves not merely as citizens of the world, but, with a true cosmopolitan spirit, as citizens of the universe. Matter changes form, but it is not created and it does not die. When the sun is dead and the earth is in darkness, the wheels of life will still run in the light of other suns; and even our ashes may yet thrill with new life, on a new earth, in the beams of a new sun. 


\section{ABSTRACT OF THE DISCUSSION.}

\section{Dr. Robert G. Eccles:-}

The lecture of Mr. Serviss has been highly irteresting as well as instructive. He has handled his subject with a degree of ability and candor highly praiseworthy.

The nebular theory of Laplace is a very fascinating one, and at first sight seems to give us a picture of conditions that might have evolved our Solar System. Its fundamental principles are undoubtedly sound, but the more we study the matter in detail the less likely we are to acquiesce in it as a conclusion. The speaker has already called our attention to a number of weak points, and told us of several modifications of it which have been adopted by leading astronomers. The fact that irresolvable nebulæ exist, and that the spectroscope declares them to be in a gaseous condition, is beyond dispute. The further fact that science, in retracing the earth's history, is irresistably carried back to a condition of intense heat as the primal cosmic state, is equally true. So far all are agreed. To look upon the pictures of the various nebulæ which have been shown us to-night seems, to my way of thinking, to pretty thoroughly negative the conclusions of Laplace. At least they do not seem destined to form any such systems as ours is. The lack of serial connection, as well as lack of uniformity in their conformation, seems to show that no two of them are rushing toward a common destiny. Some do show a suggestion of a whirl, but not of the Laplacean type.

Such a theory seems to me to violate the basic laws believed in by modern evolutionists. It begins with a highly specialized form of motion, and gives no hint as to its genesis. There is altogether too much order, where we should find chaos. What is the cause of the rotation? Why does the matter all tend to one rather than many common centers? We have numerous reasons for believing that a mass so vast, when cooling, would not cool evenly, nor move evenly. We have none for believing the contrary. The nebula in Orion looks very like an ideal of the primitive state of this solar system which I presented at a meeting of the old Brooklyn Philosophical Society many years ago, and at which our present 
chairman was present. In that, it was assumer that the mass, in cooling by radiation, did so unevenly. Very many centers were necessarily formed, evaporated, and reformed again and again. Collision and crash among them brought about concentration of many into few. A veritable struggle for existence went on, upon a most gigantic scale, in which explosions, attractions and wrecks of embryo worlds were the rule. Their centralization was not upon a common plane, but in three directions, while the movements were erratic in the extreme. The present directions and modes of motion are the resultants of an incalculable number of destroyed tangents. The planets and their satellites now existing are in positions of harmonic adaptation. World-life began as precariously as animal life. The present perfected planetary existence is the outcome of a triumph over and adaptation with environment. All not in such positions, and with such motions of adjustment, were dashed into meteor's and star-dust or assimilated as food by these. Gravity still continues to shower in upon the survivor's these remnants, to increase their volume.

The late Richard A. Proctor had a theory of cosmic evolution to which Mr. Serviss did not refer to-night. He held that planets were all originally built up of meteors, and not of coalescing fluid rings. The moon he believed to have been built up of fragments originally cast from the earth. The sun's attraction, raising the liquid mass as two great tides on opposite sides of the globe, conspired with the diurnal motion to project these in showers into space. Final concentration around a common center gave us the moon. The eartlı was born in a similar manner from the sun. As multitudes of such pieces are still flying through space, all the planets and even the sun himself are increasing in bulk by their return to their parent masses.

The doctrine of the degradation of energy enunciated by Mr. Serviss has never seemed to me to be altogether a sound one. We do not know the cause of gravity nor of affinity, and, until we do, speculations of this kind, especially as they lead to such doleful conclusions, should be curbed. Gravity itself may be a product of the evolution of matter. So also may be chemical affinity. If they developed pari passu with the fire-mist, the round of change may break their links and set all primal substance free again. The chilling process may, for anything we yet know to the contrary, bring on a rhythm in matter that will break cohesion, affinity and gravity, releasing everything into the universal urstaff from which the fire-mist was begotten. To believe that suns will co- 
alesce with suns, and worlds with worlds, to be thrown back again and again with diminishing force, till at last the whole universe ends as a dead, black, monster furnace-slag, is to reason from insufficient data and come to improbable conclusions. An incalculable period of time has already gone by, and the finite energy we know of should long ago have been degraded and escaped. The universe should already have been a slag; butit is not. Substance per se, in cycle of experience from invisibility to matter, is much more likely to have a rhythm of contraction and union with expansion and disunion, through inherent forces, than worlds are likely to rush into each others' embrace and be cast off again. Let the physical cause of cohesion cease, and there will no longer be such a bond. How do we know that cohesion is uncaused? How do we know that gravity has not a physical condition producing it? Dissolve that condition and where is gravity? Remove gravity, cohesion and affinity, by evolving out of the physical conditions producing them, and all things will gradually melt into the impalpability of the universal ether from whence they first came. Here they can once more commence their career, while the law of continuity is allowed to pursue the even tenor of its way without that bugbear of every embryo science, cataclysm. Natura non facit saltum.

\section{Professor P. H. VAN der Weyde:-}

I do not think that the theory of Laplace, so clearly explained and illustrated by the lecturer, properly accounts for the formation of our solar system. When motion originates from the center of a mass, and is communicated outward, as in Laplace's theory, the inside of each fluid ring, on separation, will more more rapidly than the outside; and when the ring breaks, the direction of rotation of the resulting globes will be opposite to that of the central mass. This is the reverse of what we see in our solar system. We have, however, only to conceive of matter dispersed through space in a highly rarified state,-dispersed unequally as regards quantity and quality,-and then the operation of the simple law of gravitation is sufficient to explain the formation of all solid, liquid or gaseous masses forming our solar system.

We have to start with nebulous matter cliffused through space, and mutually acting and acted upon by the universal force of gravitation. The reaction of this force, commencing from the outside and acting inward toward centers of condensation, would perhaps 
first cause the balling together of some small liquid or solid masses like meteorites; a series of these meteorites would commence to revolve in rings, and, attracting one another, would diminish in number and increase in size. The largest of these bodies, in a given region, growing larger by accessions from all directions, would become more and more heated, by the triple cause of converging motion and impact, pressure on their centers, and chemical action by the contact of the different elements constituting them. These wonld constitute the suns, around which the smaller bodies would revolve.

The result of atoms and meteorites thus converging would be to produce in each a spiral motion toward the center, increasing both the angular and the direct velocity of each, until the force thus generated became powerful enough to balance gravitation, when rings would form, ultimately breaking up into planets. The outside of each fluid ring, in this case, would move more rapidly than its inside, and the resultant globes would therefore rotate in the same direction as the central mass. This is the case in our solar system, with all the planets inside the orbit of Uranus. The contrary motion of the two outer planets renders it probable that there was a projecting part of the primitive nebula, between which and the main mass the chief current of rotation found its way. Thus, the simple law of gravitation, acting upon nebulous matter unequally diffused through space, is sufficient to explain all the results observed in this admirable system of worlds.

\section{Tire President, Dr. Lewis G. Janes:-}

There is evidently a wide field in this discussion for the exercise of the scientific imagination. The point to be noted is, that although astronomers are not agreed as to the precise method by which the suns and worlds have been brought into being, there is a very general agreement that it has been effected by natural causes - by some process of evolution.

I desire to call your attention, as relating to a subsequent branch of this discussion, to the fact that there are two classes of philosophical thinkers who can logically take no interest in this evening's discussion. First, the Positivists, who can see no direct bearing of astronomical studies upon human welfare, and therefore leem them unworthy of our serious attention, classing them with those metaphysical and ontological studies which they affect to condemn. Secondly, the consistent Idealist, to whom all this vast realm of the heavenly spaces - the universe itself - is but a fig- 
ment of the imagination, the subjective creation of the individual mind or ego. If there is any rational conception of evolution possible to the Idealist, it is an evolution which is purely subjective - an evolution of thought, not of material things.

The coming philosophy of evolution, it appears to me, will furnish a more rational solution of these problems of thought than either Positivism or Idealism proposes; - a solution in harmony with science, realistic and monistic in its conception of the Ultimate Reality, and furnishing, therefore, a rational ground of explanation of those concomitant mental and physical phenomena - as of the relation of molecular changes in the brain to consciousness - which have so long been the despair of science and the supreme enigma of philosophy. 



\section{EVOLUTION OF THE EARTH}

BI

\section{LEWIS G. JANES}

Author of "A Stedy of Prinitive Christiantey," "The Scientific: ANd METAPHY'SCAL METHONS IY PHILOSOPHY," ETC. 


\section{COLLATERAL READINGS SUGGESTED}

IN CONNECTION WITH ESSAY IV.

Haeckel's History of Creation; Lyell's Geology; Le Conte's Ge. ology; Dana's Geology; Winchell's World Life; Clodd's Story of Creation; Ramsay's Earth Sculpture; Heilprin's Geological Evidences of Evolution. 


\section{THE EVOLUTION OF THE EARTH.*}

THIs beautiful home of ours, the earth-how was it built? - who were its builders? What are the forces that have fashioned and prepared it to become the habitation of man? What has been the history of the earth, since, as a molten ball, it was set upon its course around the sun? These are the questions which we are to attempt to answer to-night. What the cosmogonist has to tell us of the earth's earlier history, we have already learned from the delightful lecture of Mr. Serviss. We have seen how, from the primitive and almost homogeneous fire-mist, the suns and planets have been evolved, by a process of differentiation and integration, proceeding from the indefinite, incoherent, homogeneous, toward the definite, coherent, heterogeneous condition illustrated by the present state of our solar system, thus fulfilling the fundamental law of evolution as laid down by Mr. Spencer. $\dagger$ We have learned that while there is some difference of opinion as to the exact method by which this grand result has been accomplished, there is no doubt in the minds of scientific thinkers that the process has been orderly and natural from first to last, impelled by the operation of laws and forces which are still operating, and whose action is familiar to us,- forces which are resident in the matter out of which the universe is builded,- without the aicl of supernatural interference or miracle.

How, then, is it with the subsequent history of the earth? We all know the old way of accounting for all this: how, as the legend runs, in six days the Lord not only brought the world into being, gave it the sum and moon and stars,"the greater light to rule the day, and the lesser lights to rule the night," - but also clothed it with the verdure of

* Coprright, 1889, by The New Ideal Publishing Company.

$\dagger$ Evolution involves " the integration of matter and concomitant dissipation of motion, attended by a continuous change from indefinite, incoherent homogeneity to definite, coherent heterogeneity of structure and function, through successive differentiations and integrations." 
grass, herbs and trees, and peopled it with a myriad forms of life, giving all to man as the crowning glory of creation, into whose nostrils he had breathed the breath of life. The Genesis story is a simple, graphic and suggestive legend, which, when we have ceased to regard it as a statement of scientific: truth, we would by no means expunge from the sacred litcrature of the world. It contains some hints of man's primitive conception of cosmogony, some theory, crude and imperfect as it is, of the way in which life began in the world; but there is not even a suggestion in it of this wonderful story of geology about which we are to think to-night. The visible heavens, and the surface of the earth were known to man in those earlier days; but of what lay within the bosom of the earth, of the forces which had upheaved its mountains, excavated its valleys, prepared it. for the teeming life which he beheld around him, he knew practically nothing. The sky to him was a solid firmament; above it, perhaps, the heaven of his imagination, the home of his gods. Beneath the earth was the subterranean abode of the dead, out of which conception the observation of the lurid fires and destructive energy of volcanoes naturally helped him subsequently to evolve the notion of a fiery hell.

'To the modern mind all this is changed, as by the touch of a magician's wand. Where, indeed, can we find a magician as potent as Star-eyed Science, which transforms the misty nebulæ into suns and galaxies, and the rocks beneath our feet into pages of sublimest history? Let us now turn to the study of these pages, writ all over with stories of the past, and trace therein as well as we may, in the brief time allotted to us, the history of the earth.

Primitive Condition of the Earth's Surface. When the surface of the globe had parted with its heat sufficiently to allow the vapors of the atmosphere to condense and descend in rain, it had already become somewhat less homogeneous in form and structure than it was in its original heated condition. The solid crust had become differentiated from the fiery core. Cooling was accompanied by contractıon, which produced inequalities of altitude, though less. marked than those presented by our present mountain ranges. Relatively to present conditions, the solid portion of the earth's surface may be said to have presented a homogeneous structure. There was no soil, capable of sustaining 
vegetable life, there were no stratified rocks; - the earth was a vast cooling cinder when the forces began to operate which have produced the manifold forms of life and beauty that now diversify its surface. The great agencies which have effected this evolutionary process, may be classed as atmospheric, aqueous, igneous and organic. The former two, the atmospheric and aqueous, have been leveling and apparently destructive; tearing down rocks and mountains, creating sand and soil, filling the valleys, and making the rough places of the earth smooth, softening its original hardness. The latter, the igneous and organic, have been upbuilding and creating agencies, lifting islands and continents out of the ocean beds, and elevating mountain ranges, thus modifying the climate and productiveness of favored localities; though igneous agencies have sometimes. operated destructively as well as constructively.

Action of the Atmospheric and Aqueous Agencies. Up to the time when our history opens, the igneous agencies, together with the great cosmic force of gravity, had been mainly influential in moulding the earth, and shaping its external form. With the condensation of the watery vapors, and their descent upon the earth, the aqueous and atmospheric forces became for a time the dominant agencies. in effecting geological transformations. As the surface of the earth was much more level than at present, the continents and islands were smaller and fewer in number than they are now; the seas were shallow, but a much greater proportion of the earth's surface was covered with water. Let us now consider how the atmospheric and aqueous agencies would operate in transforming the exposed areas of land, and what processes would go on in the depths of the oceans and lakes, and along the river-courses.

If we go over to the Palisades on the west bank of the Hudson River, we shall observe, as we know, several miles of almost perpendicular cliffs, reaching a height at one or two points of more than five hundred feet. All along the foot of the cliffs, we find masses of broken rock and debris, growing from year to year by the falling of portions of the rock which are loosened and separated by the action of water, snow and frost. This action goes on most rapidly in the winter and the spring. The water and snow are blown against the cliff, permeating the crevices in the rocks. Freezing and expanding, the ice splits the solid mass asun- 
ler, dislodging portions, and creating iarger crevices and fissures. Masses of the rock are undermined, and fall, and are pulverized by the subsequent weathering. In this way rain, snow and frost are continually at work, making soil and other forms of detritus from rocks. Some such process as this went on during those early periods before life and vegetation appeared on the earth; for life and vegetation lemand soil, and all the soil which now covers vast areas of the earth's surface was originally made by slow processes of disintegration and attrition, from the rocks. Only, in those primitive times of which we speak, the rocks were not the same in character as those of the Palisades - those the world over on which the forces of nature are acting today; - for these in their turn, or most of them, have been formed from the detritus of disintegrated rocks by processes hereafter to be described. The earlier soil, as well as the atmosphere, was, therefore, of a different character from that of to-day, adapted to the production of a coarser, more luxuriant, less delicate and beautiful regetation. If we take a section of the material which lies at the bottom of any high cliff like the Palisades, or around the bases of mountains, we shall find that it is composed of the same material as the cliff or mountain above. Thus, partly by atmospheric agencies, by rain, frost and snow, by the action of the sea as it breaks against the cliffs along the shore, partly by glaciers - those rivers of ice, which slowly, but with tremendous energy, wear their way down from mountain heights until they melt in the heat of the low-land sun - all the soil upon the earth, all the sand upon the deserts, all loose material, has been formed.

Evidencies of glacial action are wide-spread in both Europe and America. Glacial drifts - immense boulders, removed a long way from the native rock from which they were separated, often left on the summits of high hills; pebbles and cobble-stones, worn by attrition, - the loose drift and soil of glacial moraines, - may be found all through our Northern country. Scratches or grooves made on the surfaces of the rocks by hard stones caught in the ice, and dragged along by the force of the trend, indicate the direction of the glacier's flow. 'The region of glacial action may be mapped out with accuracy wherever its effects have been closely studied. The glacial moraines form many of the hills which we now observe in the regions where glaciers 
operated. Besides its influence in disintegrating rocks and forming soil, glacial action has notably affected the conformation of the earth's surface in many places, forming hills, as we have said, excavating valleys, and even altering the natural boundaries of the land and sea. Anglesea Island, near Wales, for example, is supposed to have been separated from the main-land by the action of a great glacier which descended from the mountains of the Lake Region, ploughing its way across the bed of what is now known as the Irish Sea, and excavating a narrow channel in the soft rock which previously connected Anglesea with the main-land.*

The soil formed by these various agencies even as we see it to-day - and at no earlier period was it more abundant is, however, scarcely more than a carpet covering here and there the hard floor of rock. It is easy, almost anywhere, to dig through this carpet; or if you go down into the coal or iron mines of Pennsylvania, or the marble quarries of Vermont, you will see how thin is this superficial covering, and that underneath it everywhere is the floor of rock. Proceeding with our investigations, we will now observe the character of this underlying foundation, as it exists today, and study the processes by which it has been formed.

Present Condition of the Earth's Interior. Let us first say a word, however, as to the present condition of the earth's interior. Assuming that the world was originally a mass of fiery matter, it was formerly believed that as the process of cooling would naturally go on most rapidly on the surface, the interior must still be in a molten or fluid condition. As we descend in mines or quarries beneath the earth's surface, we find that the temperature increases about. 100 degrees for every mile of perpendicular descent. $\dagger$ As we ascend a mountain, on the other hand, the temperature falls. Upon the Alps, in summer, this fall amounts to about one degree in 439 feet of perpendicular ascent, and in winter, one degree in every 290 feet. Even on the equator, therefore, if we ascend high enough, we may reach a region of perpetual winter. It is only within a narrow range, vertically, over the surface of the earth that animal or vegetable life is possible. The increasing heat as we descend into

* Ramsey-"Earth-Sculpture."

† The observed changes vary in different mines from about one degree in 50 feet to one degree in 75 feet. The deepest descent into the earth at which experiment has been made is about 3000 feet. 
the bowels of the earth, would at first appear to favor the theory of the molten condition of the interior. The phenomena of volcanoes and earthquakes have also been adduced in support of this theory. At present, however, it is the juclgment of the best authorities in geological science that the imner core of the earth, though intensely hot, is not in a liquid, but in a glutinous-solid condition; - in a pliable state, but much more dense, even, than the solid rocks which we see around us. The reason for this conclusion is the recognition of the effect produced by the immense pressure exerted on the earth's interior by the superimposed material. The entire weight of the earth has been estimated to be about $6,000,000,000,000,000,000,000$ tons - a number entirely too great for the human imagination to grasp. When we reflect that the atmospheric pressure, at the level of the sea, amounts to fifteen pounds to each square inch of exposed surface, we can imagine - or rather, we cannot imagine - the immense pressure exerted on the inner core of the earth by the masses of material above and around it; sufficient, no doubt, to compress it to a dense, viscous mass, in spite of the expansive power of its extreme heat.* It is only where some fissure or flaw in the superimposed strata relieves it from a portion of this pressure that it liquefies as it comes to the surface in volcanoes.

Formation of Stratified Rocks. We have seen how the soil is made by various processes of attrition and disintegration from the rocks. We have now advanced so far in our investigations that we can go on to study the manner in which the stratified rocks have been formed. 'The earth's floor wherever it is exposed, or as it would appear if this carpet of soil and vegetation were removed, is composed of a wonderful variety of formations. Think, for example, of the number of kinds of stone used in building - granite, marble of many varieties, limestone, sandstone, slate, many other's will occur to you - but these constitute only a portion of the almost endless variety of rocks which the geologist has discovered and named, and all of them have been produced by processes of differentiation and integration, from the primitive material of the earth's crust. These rocks are spread over the earth in a very irregular manner. If you were to make a map of them, it would exhibit a most

* Enormous pressure would be exerted, notwithstanding the variation in the force of gravity as we approach the center of the earth. 
intricate and diversified appearance. Iet beneath this infinite diversity there is discoverable a certain order and relationship, so that we may ascertain how these rocks came into being, to what geological period they belong, their relative age, and we may sometimes determine the causes which gave them their present local habitation. The greater portion of the earth's surface is covered by what are termed stratified or sedimentary rocks; that is to say, they are rocks which are formed by the action of water, and are found deposited in superimposed strata or layers. Sometimes these strata, in turn, are built up of an immense number of thinner iaminæ, or scales. This formation may be observed at many places - as at Portland, Connecticut, in the sandstone quarries, and along the banks of Green River in Utah Territory. Often an exposure of twenty feet will reveal as many as from sixty to eighty superimposed layers. Originally the stratified rocks must have been deposited horizontally. On the edges of cliffs and canons and along the sides of quarries and mines, they may sometimes be found and studied in this position. Often, however, they have been tilted and contorted by the horizontal crushing of portions of the earth's surface, so that their edges are exposed in an inclined, sometimes in a vertical position; occasionally they are even tilted over so that their original position is reversed.

The question for us now to consider is, How were these stratified rocks originally formed? 'To answer this question, we must observe more closely the action of brooks, rivers, lakes, and of the ocean. When a current of water is moving swiftly along, its force is sufficient to carry with it not only the finer particles of sand and soil, but also pebbles of considerable size. The larger fragments are first deposited in the shallow waters nearest the fountain-head of the streams. The finer portions of sand are swept along by the current, sinking more slowly and forming layers at the bottom, while the still smaller particles of sediment travel much farther and are deposited very gradually near the mouths of the rivers or at the bottoms of larger bodies of water. Doubtless many of you have followed the course of a mountain stream, as I have done in the Catskills and White Mountains, and observed the effects of this process. In its earlier course, where the water shoots swiftly along over rocks and ledges, what do you find in the bottom of 
the stream? Large rocks and boulders, perhaps, from which the finer material has been washed away; pebbles and coarse gravel, but no fine mud. The finer sediment has been carried on to the lower country whither the stream is making its way; and there, if you observe, you will find that the bottom of the stream is covered first with fine sand, and farther on, as it wends its way slowly through the level country, with layers of mud or clay. Thus, everywhere along the course of mountain torrents, in brooks and rivers, and inland lakes and in the mighty ocean itself, has gon on the process of differentiation, breaking up the primeval rock, distributing its particles, and preparing for the later stages of the transformation. 'This action of rivers and water-courses was probably somewhat augmented at the close of each glacial period, when the vast masses of ice were melting, flooding the valleys with water, changing their form by the force of the torrents, and everywhere depositing new layers of detritus.

Let us now observe what goes on in this subsequent part of the process, - how the work of integration is effected. We cannot see what takes place at the bottom of the ocean, but we can judge of it by observing similar processes along the banks of our lakes and rivers. At certain periods they become dry - the sectiment at the bottom is exposed. $\mathrm{Or}$, we can watch what occurs where pools of water have been formed in depressions of the soil by a heavy rain, after the water evaporates. We can cut through a layer of the deposited sediment and observe what it contains. The upper' portion of it will exhibit the later deposits of silt thrown down as the water was ebbing away, mingled with dead. leaves and sticks and whatever may have been caught in the eddies of the stream and held fast as it subsided; the lower part, the coarser gravel. If consolidated into rock, this gravel forms a loosely compacted conglomerate, or "pudding-stone"; the finer sand the different varieties of sand-stone, according to the material of which it is composed, and the still finer mud and silt, some kind of shale or slate. Much of the material of which sandstone is made is deposited in shallow water along the shores of the sea. When in its original state, before it is dried and solidified, it readily receives the impress of whatever is brought in contact with it. If a second layer of sand is blown into the impressions. 
thus formed, filling them and gradually hardening without disturbance, the impressions are preserved by the subsequent hardening of the stone. In this manner have been preserved the foot-prints of enormous birds and reptiles, in the sandstone of the Comnecticut valley and elsewhere, specimens of which can be seen in the geological cabinets at Yale College, at Amherst, and at other places. In the lower beds of sandstone we find ripple marks and the imprints of rain drops, showing that the sand of which the stone was formed was deposited in shallow water and was occasionally left dry and exposed to the action of rain. These phenomena may also be observed in the sandstone of the Connecticut valley. The same process of depositing sediment goes on, on a much larger scale, at the bottom of the lakes and of the ocean. There is abundant evidence that while these layers of comminuted material are being leposited, the surface of the earth has been subjected to alternate periods of subsidence and elevation. Almost all of the land which now forms our continents and islands was at one time under water; while much that is now at the bottom of the ocean has, at some period, been dry land. By the accumulation of superimposed deposits and the consequent pressure which their weight brings to bear on the lower material, by the elevation of submerged areas, by the gradual infiltration of lime and other saturated material, and by subsequent chemical changes, the layers of deposit. are slowly hardened into stone. The rocks thus formed are naturally not mere solidified heaps of rubbish, but by the action of the water they have been differentiated and arranged in definite, orderly layers, to each of which the geologist gives a name appropriate to its characteristic features. Last summer, on the top of the highest peak of the Green Mountains, * I found the characteristic stone to be a conglomerate or "pudding-stone," formed of coarse pebbles and gravel, loosely packed together, showing that the material of which it was formed was originally deposited in shallow water along the shore of some ancient sea. A similar conglomerate constitutes much of the rock around Newport, and along the New England coast at the present. time.

* Killington Peak, near Rutland, Vt., is a few feet higher than Mt. Mansfield, as indicated by the most recent surveys. 
Fossil Remains in the Sedmentair Rocks. Thus far we have spoken only of the soil and gravel, the sand, mud and pebbles of which the stratified rocks are composed. They exhibit, however, other features of great interest to the geologist and to the student of evolution.

We have seen how, in the section of material accumulating by a brook-side, or in wayside pools after a long and heavy rain, we not only find the mud and sand and gravel of which it is composed, but also dry leaves, and sticks and debris of various kinds. We have seen also how the impressions of footprints, rain-drops and ripples are left in the sand and preserved in stone. The same result, on a much grander scale, is observable in many of our stratified rocks. If you search along the bed of a shallow creek in Chautauqua County or elsewhere in the western part of this State, until you find or can dislodge a loose piece of shale, or stratified rock formed from the mud deposited in the bed of the creek, and observe it closely along its line of natural cleavage, you will find there the clear impressions of beautiful ferms or the shells of aquatic animals, sometimes complete petrifications of nuts and other remains of vegetable or animal life. These are perhaps of comparatively recent formation; but in the stratified rocks along the mountain ranges in the interior of continents, which centuries ago were formed at the bottom of the ocean, we may discover the fossilized remains of distant ages, and trace thereby the evolution of life in far away geological periods. These remains, though mainly, are not exclusively those of marine animals; they include the remains of sea-vegetation, and vegetable products which grow upon the land are sometimes floated out to sea, and dropped among the sedimentary deposits which are continually collecting in its bed. These fossil remains, as you will readily understand, are of the utmost importance in enabling the naturalist to trace the early history of the development of vegetable and animal life upon the planet. By observation of them, the relative age of each geological stratum may frequently be determined.

The Formation of Organic Rocks. This is not the only curious and wonderful result of the study of the stratified rocks. Sometimes we find that organic material is deposited in such quantities as to form strata of great thickness, composed mainly or exclusively of this material, which are ultimately solidified into rocks. Some rocks are, there- 
fore, composed entirely, or almost entirely, of organic remains. Coal, for example, which exists in such vast quantities in many portions of our country, especially in Pennsylvania, is almost pure carbon in its chemical composition, is deposited in layers like the sedimentary rocks, and is really so much vegetation which has been hardened into stone. During the Carboniferous era when the material of which the coal-beds are formed was produced, the atmosphere was densely loaded with carbonic acid gas and aqueous vapors. Nearly one-half of the earth's crust is said to be composed of oxygen and other materials which originally existed in a gaseous condition. The purification of the atmosphere from these vapors and gases, constituted another example of differentiation and integration illustrative of the law of evolution.

Beneath a section of a coal-seam, you may often trace the blackened lines of the roots of former trees, stretching down into the lower stratum of rock or clay. Originally, this rock or clay was a bed of soil, in which grew a luxuriant vegetation. Some of the mines in Nova Scotia present as many as seven different layers of forests, which have grown during the lapse of ages, each in turn above others, until at last, all have been consolidated into coal. Examine a thin piece of soft coal under a microscope, and you may often find millions of little sporangia, or seed vessels, - the product of a kind of moss which was pressed into beds of peat, and then hardened into coal. In the peat bogs of Ireland, in our own country, and elsewhere, this process is still going on, though much more slowly than during the Carboniferous period, laying, possibly, the foundations of coal-beds for the use of future generations. In the rock underneath or above the coal-beds, you may sometimes discover fossil forms of the trees and larger plants out of which coal is formed. Some of these trees are of curious conformation, having leaves growing directly from their trunks, instead of on limbs and branches. The scars left by these leaves when they dropped off are still visible in the petrifications.

Not only are stratified rocks thus formed out of vegetable material, they are also built up out of animal remains. Last summer, during my annual vacation, I spent a delightful fortnight with a congenial comracle, walking through the beautiful hill-country of Western Massachusetts and 
Vermont. In the latter State, we visited several of the famous marble quarries, which furnish its people with one of their leading industries. In one of these quarries, at West Rutland, my friend descended three hundred feet below the surface, - farther than I cared to climb in an August day. On either side through the whole distance were continuous layers of marble, the foundations of which had been built up during the patient centuries out of minute organic remains - the skeletons, so to speak, or the shells rather, of once living animals. Subsequently, the limestone thus formed was structurally metamorphosed by the action of heat,* so that the evidences of organic life were destroyed. How much deeper the vein extended, I do not know. This formation, in many places, reaches a depth of 2000 feet. These vast beds of limestone and marble, therefore, now just beneath the sloping sides of the Green Mountains, several hundred feet above the level of the sea, and elsewhere widely distributed over the earth, were formed of deposits which originally lay on the very bed of the ocean. How can we estimate the time required to effect such a transformation? The deposit, through slow-creeping ages, of the shells, their consolidation into rock, the change of structure by the action of heat, if the material be marble, the gradual upheaval of the ocean-bed, the elevation of the mountain ranges, the slow accumulation of soil above the rock; - verily, "the more thou searchest, the more shalt thou wonder." "The great Pyramids of Egypt, the oldest and most enduring products of human art, are built of limestone. They embody the results of the patient energy of untold millions of living creatures, besides their human architects and builders.

Take a little ooze from the bottom of the ocean, dry it and examine it through a microscope, and you will discover that what appeared to be small grains of dust, are so many minute shells - some of them broken, but many of them perfectly formed, all of them of most delicate and symmetrical proportions. These shells are called Foramenifera. They are crowded together, millions upon millions of them,

* The Vermont marble is a crystalline limestone, from which all direct evidences of animal remains have been destroyed; it is assigned, however, to the lower Silurian or Cambrian division of stratified rocks, and has been identified as belonging to the Chazy limestones of that geological period, of organic origin. Some crystalline limestones may have been formed by chemical processes. without organic intervention. 
in the bottom of the sea, accumulating century after century, forming a deposit which, as it increases, will cover and enclose the shells and remains of larger creatures, reaching perhaps in time a depth of several hundred feet. Now, if we take a piece of common chalk, and examine it through the microscope, we shall detect shells and the remains of animals very similar to those we found in the ooze. The chalk, indeed, is entirely made up of these organic remains. IVe know that it is now found in immense cliffs, hundreds of feet in height, at Dover and elsewhere in England, in France and in Sweden, and in other parts of the world. Flint nodules are also formed in chalk-beds, the diatoms which constitute their nuclei separating from the Foraminifera and drawing to themselves concretions of silica and iron. Such examples as these offer conclusive evidence to the scientific mind of the fact that immense areas of land, even high cliffs and lofty mountains, were once situated at the bottom of the sea. None but the grossly ignorant would now argue, as it was seriously argued in no very distant period of the past, that God created these semblances of former life where they are now found, and that they afford no proper evidence of the long duration of geological periods. It remained for Christian writers and theologians as late as the fifteenth, sixteenth, seventeenth and eighteenth centuries, and even of the nineteenth century, to soberly propose this absurd hypothesis. The Pagan scholars of olden times had noted the evidence of marine shells on mountain tops and at a distance from the sea, and rightly concluded that these facts were indicative of former changes in the earth's surface, - that the rocks in which they were found had originally been submerged beneath the ocean. Such was the judgment of scholars like Pythagoras, Plato, Aristotle, Strabo, Seneca, and Pliny. Our sixteenth century Christians, howerer, denominated such phenomena "sports of nature," or attributed them to "the plastic force of nature," and dated them from the original rreation of the world. Even Voltaire, who attempted an explanation in accordance with reason, thought that these shells had been left on the mountains by the Crusaders, as they marcherl to the Holy Land,- being the refuse of their repasts. It took a full century to explode this idea of the "plastic force of nature," and a century and a half longer to show the absurdity of the hypothesis that they were 
left where they are now found by the subsiding waters of Noah's deluge. The great mind of Leonardo da Vinci was the first in the later Christian times to propound the true scientific theory of their origin; and he and later scholars of the Italian renaissance were the real fathers of the modern science of geology.

Continents and islands are even now gradually rising from the ocean; mountain ranges have been differentiated and integrated by processes of gradual elevation. Elsewhere the solid land is yielding to the encroachments of the sea. We all realize the very visible effect of this destructive action of the waves, as it goes on from year to year at Coney Island. It is said that Montauk Point, at the eastern end of Long Island, is two or three miles west of where it formerly was, as indicated by indisputable geological evidence. The coast around New York, in many places, is washed away at the rate of two or three feet a year; and in the Eastern part of the continent the encroachment of the sea progresses at a much more rapid rate. The rate varies in different localities according to the conditions of exposure, and the hard or yielding character of the rock which constitutes the substratum of the soil. The sand, which forms the beaches so attractive to the seaside visitor in summer, has all been made by the gradual grinding down of the silicate rock by the attrition of the waves, and by other natural processes. On the other hand, the rivers are all the time at work carrying material into the sea, and thus gradually raising its level. If no other agencies than the destructive ones were at work, it has been estimated that the sea, in time, would wear its way to the center of the largest continents. I have said that continents and islands were gradually rising from the sea, at the same time that these destructive forces are operating elsewhere. I did not refer exclusively to those slow processes of elevation, of the operation of which we are scarcely aware, though careful experiment has determined that they are still in progress; but also to the even more wonderful work of the coral polyps, which is proceeding in the warmer parts of the globe. The southern end of our Florida peninsula, for example, is the product of these little creatures. In the South Pacific ocean, coral reefs and islands have already risen above the level of the sea, and are crowned with luxuriant. 
vegetation. If the work of the coral polyps should continue, undisturbed by counteracting agencies, these little creatures might ultimately build a continent five or six thousand miles long, and twenty-fire hundred miles in width - a continent larger than North America. It has been shown, however, by Professors Le Conte and Dana, that that portion of the earth's crust is subsiding so rapidly that no such result can be reasonably anticipated.*

The Formation of Igaeous Rocks. We have already spoken of the original rock on which the present diversified structure of the earth's surface was founded, as being of igneous origin. It is probable that none of this primitive formation is now anywhere visible. Yet everywhere, underneath the stratified rocks, lies a formation of gneiss or granite, or other form of igneous rock. These are all, doubtless, what are termed metamorphic rocks, which, whatever their original character have been structurally changed and dislocated by the action of heat and the chemistry of nature. The granite and crystalline rocks, such as we find dominant in the White Mountain system, and to some extent in the Green Mountains and elsewhere in the Northern part of America, have been formed by igneous agencies, under the immense pressure of superimposed masses of rock. By lateral pressure, due to the gradual contraction of the earth's crust, and by the slow movements of depression and elevation which are constantly operating, cracks or "faults" have been formed in the stratified rocks, through which the granite and igneous matter beneath has been pushed up and extruded while in a molten state. Earthquakes sometimes result from this "faulting" or disarrangement of the strata. These movements are doubtless due, primarily, to the heat of the earth's interior, and secondarily, to the consequent process of cooling and secular contraction. Volcanoes, also, are constantly throwing out lava, and other igneous products, thus to a certain extent modifying the earth's surface. This influence, at present, is infinitesimal compared with the other agencies which we have noted; though the number of extinct volcanoes, and other evidences of their former action, indicate that in previous ages of the world's history, it was a much more active modifying force than at

* See Le Conte's “ Geology." 
present.* The most remarkable volcanic irruption of recent times was that which occurred on August 26 and 27, 18S3, at the island of Krakatoa in the Straits of Sunda, midway between Sumatra and Java. Streams of volcanic dust were thrown to an estimated height of 17 miles, and more than a cubic mile of material was expelled from the rolcanic crater. Accurate scientific investigations, conducted under the authority of the Royal Society of England, have determined that the air-waves, whose vibrations were originated by this volcanic action, travelled from Krakatoa to its antipodes around the entire earth not less than seven times. The automatic records of the barometer at Greenwich near London responded to their influence six or seven times, and similar effects were reported from Berlin, St. Petersburgh, Valencia, and elsewhere. People ninety-six miles away, on the island of Sumatra, were aroused from their sleep by the concussions; the sea-waves created thereby destroyed numerous villages, and 36,380 lives on Java and Sumatra. Incredible as it may appear, the noise was heard at Macassa, Celebes Island, 969 miles away; at the island of Borneo, 1116 miles away, at Victoria Plains, West Australia, 1700 miles away, at Chagos Island, 2267 miles away, and even at Rodiguez, 2968 miles away. The people at Daly Water's, South Australia, 2023 miles away, were awakened by the noise, which appeared like the sound of blasting rock. The dust and powdered pumice thrown out of the crater, made the entire circuit of the world more than three times before it settled below the region of the great atmospheric currents, and was the cause of those wonderful red-sunsets which we observed during so many months subsequent to the occurrence of these phenomena. Although this irruption left no great change in the superficial appearance of the earth outside of the little island where it occurred, we may well imagine, in contemplating its effects, that volcanic action formerly played a notable and important part in the phenomena of geological evolution. $\dagger$

* The crater of an extinct volcano has very recently been discovered at Red Mountain, near Birmingham, Ala. Evidences of former volcanic action are also found in North Carolina, New Hampshire, and at various places along the Appalachian system of mountains.

† The phemomena at Krakatoa are described in detail in a quarto volume of mearly 500 pages, recently issued by the Royal Society of England. There is also a brief but interesting account, condenser from these reports, in an article in a recent number of the Contemporary lievien, by Sir R. S. Ball, I.L.D., F.R.S. 
It was formerly the accepted opinion that the great changes on the earth's surface had been mainly brought about by these cataclysmic agencies. Sir Charles Lyell, however, and the leading geologists of the modern school, have made it clear that the great geological changes have been produced slowly, by gradual processes of subsidence and elevation, and not by earthquakes and volcanic action. Compared with the slow evolutionary movements of Nature, cataclysm or revolution has played but a small part in our mundane affairs. Volcanic action and earthquakes are merely the culminations of orderly and gradual anterior processes.

I cannot do better than to close this branch of the subject with a quotation from Professor Le Conte, a master in this field of thought and investigation:-

"There was a time (not many decades ago) when all things, the origin of which transcends our ordinary experience, were supposed to have originated suddenly and without natural process - to have been made at once, out of hand. There was a time when, for example, mountains were supposed to have been made at once, with all their diversified forms, of beetling cliffs, and thundering waterfalls, or gentle slopes and smiling valleys, just as we now find them. But now we know that they have become so only by a very gradual process, and are still changing under our very eyes. In a word, they have been formed by a process of evolution. We know now the date of mountainbirths; we trace their growth, maturity, decay and death; and find even, as it were, the fossil bones of extinct mountains in the crumpled strata of their former places. There was a time when continents and seas, gulfs, bays and rivers, were supposed to have originated at once, substantially as we now see them. Now we know that they have been changing throughout all geological time, and are still changing. Not, however, changing back and forth in any direction indifferently and without goal, but gradually changing from less perfect to more perfect condition, with more and more complex inter-relations - i. e., by a process of evolution. There was a time when rocks and soil were supposed to have been always rocks and soil; when soils were regarded as an original clothing made on purpose to hide the rocky nakedness of the new-born earth. God clothed the earth so, and there was an end. Now we know that rocks rot 
down to soils; soils are carried down and deposited as sediments; and sediments consolidate as rocks - the same materials being worked over and over again, passing through all these changes many times in the history of the earth. In a word, there was a time when it was thought that the earth, with substantially its present form, configuration and climate, was made at once out of hand, as a fit habitation for man and animals. Now we know that it has been changing, preparing, becoming what it is by a slow process. through a lapse of time so vast that the mind sinks exhausted in the attempt to grasp it. It has become what it is now by a process of evolution. WVe may, therefore, conficlently generalize - we may assert without fear of contradiction that all inorganic forms, without exception, have originated by a process of evolution." **

Let us briefly recapitulate the forces which have been active in the evolution of the earth:-

\section{Igneous.}

a. The formation of the primitive rock-crust by cooling.

b. The formation of crystalline rocks under pressure.

c. Volcanic action, producing pumice, lava, basalt, porphyry, tuff, etc.

d. Action of geysers, or hot springs.

To these should be added those chemical processes, the operation of which was largely determined by conditions of heat and pressure.

\section{Atmospheric.}

a. Direct influence of wind-pressure.

b. Disintegrating influence of snow and ice.

c. Glacial action.

d. Precipitation of atmospheric gases.

e. Expansion and contraction by changes in temperature.

\section{Aqueous.}

a. Direct action of rain on the rock.

b. Action of rivers in distributing sedimentary matter.

c. Disintegrating action of ocean-waves.

d. Operation of large bodies of water in facilitating the formation of sedimentary deposits.

\footnotetext{
* "Evolution and its Relation to Religions 'Thomght," by l'rofessor Joseph Le Conte. I). Appleton \& Co.
} 


\section{Organic.}

a. Vegetable deposits, forming peat-bogs and coal-beds.

b. Shell deposits of extinct animals, forming limestone. and marble.

c. Foraminifera deposits, forming chalk-beds and marl.

d. Action of coral polyps, forming coral reefs, islands, and peninsulas.

The Order of Geological Succession. Subsequent to the period of the primeval igneous rocks, geologists recognize a succession of four great eras, three of them being divided and sub-divided into subordinate periods of variable duration. Tabularly represented, in out-line merely, these geological time-divisions appear as follows:

I. Azoic or Archcean.

II. Palceosoic, or Primary.
a. Cambrian.
b. Silurian.
c. Devonian.
d. Carboniferous.
e. Permian.

III. Mresozoic, or Secondary.
a. Triassic.
b. Jurassic.
c. Cretaceous.

IV., Cenozoic, or Tertiary.
a. Eocene.
b. Miocene.
c. Pliocene.
d. Post-Pliocene.
e. Recent, (Psychozoic.)

Tracing the order of Geological succession, in the lower non-sedimentary rocks, we, of course, find no remains of organic life. Neither have any been discovered in the sedimentary rocks of the earliest or Azoic period, though it is not improbable that early fragile forms may have existed, that left no perceptible trace. The subsequent order of geological succession is determined mainly by the order of superposition of the strata, - on the logical supposition that the undermost stratified rocks are the oldest. As we go. back toward the older rocks, we find that the fossils become more and more dissimilar to those forms of an- 
imal and vegetable life with which we are now familiar. So many changes have happened since the older strata were deposited that we do not always find them in their order of succession. Gaps sometimes occur: older rock has been forced up until it overlaps strata of a later formation. Apart from the character of the rock itself, we have in such instances the remains of organic life, which enable us to identify its proper place in the order of succession. In this way we can identify rocks of the same geological period, on different continents and in diverse parts of the world. In general, however, the forms of life indicated by fossil remains in given geological strata in America, are somewhat older than those found in corresponding strata in the Eastern hemisphere.* Palæontologically, as well as geologically, America appears to be the oldest continent. We are also sometimes enabled to trace the history of the spread of the fauna and flora from one part of the world to another. In the Samoan Islands and other islands of the Pacific ocean, the only indigenous mammal is a species of bat - the only mammal which could travel far from its native habitat, over leagues of ocean,- - a significant fact from the stand-point of evolution. In the Arctic regions of the Eastern and Western continents the flora are in many instances identical, or of the same species. This is not because the seeds or plants were carried from one continent to the other across the ocean and thus propagated, but, as geology assures us, because the two countries are in near proximity - practically almost united by the presence of vast fields of ice, while in a former period they doubtless constituted one continent. All the horses now living in America are derived from imported stock. History tells us of the wonder of the aboriginal inhabitants of this continent when they first saw the European invaders on horse-back. Yet fossil horses are found in the Post-Pliocene remains in this country, and Professor Marsh has discovered in our Western territories the ancestors of the horse - the Pliohippus, the Protohippus or Hipparion, the Miohippus or Anchitherium, the Mesohippus, Orohippus or Hyracotherium, and the Eohippus, in the geological remains of the Upper Pliocene, Lower Pliocene, Upper and Lower Miocene, and Upper and Lower Eocene periods, respectively, which in their successive order,

* "Introduction and Succession of Vertebrate Life in America," by Prof. $O$. C. Marsh. Iage 24. 


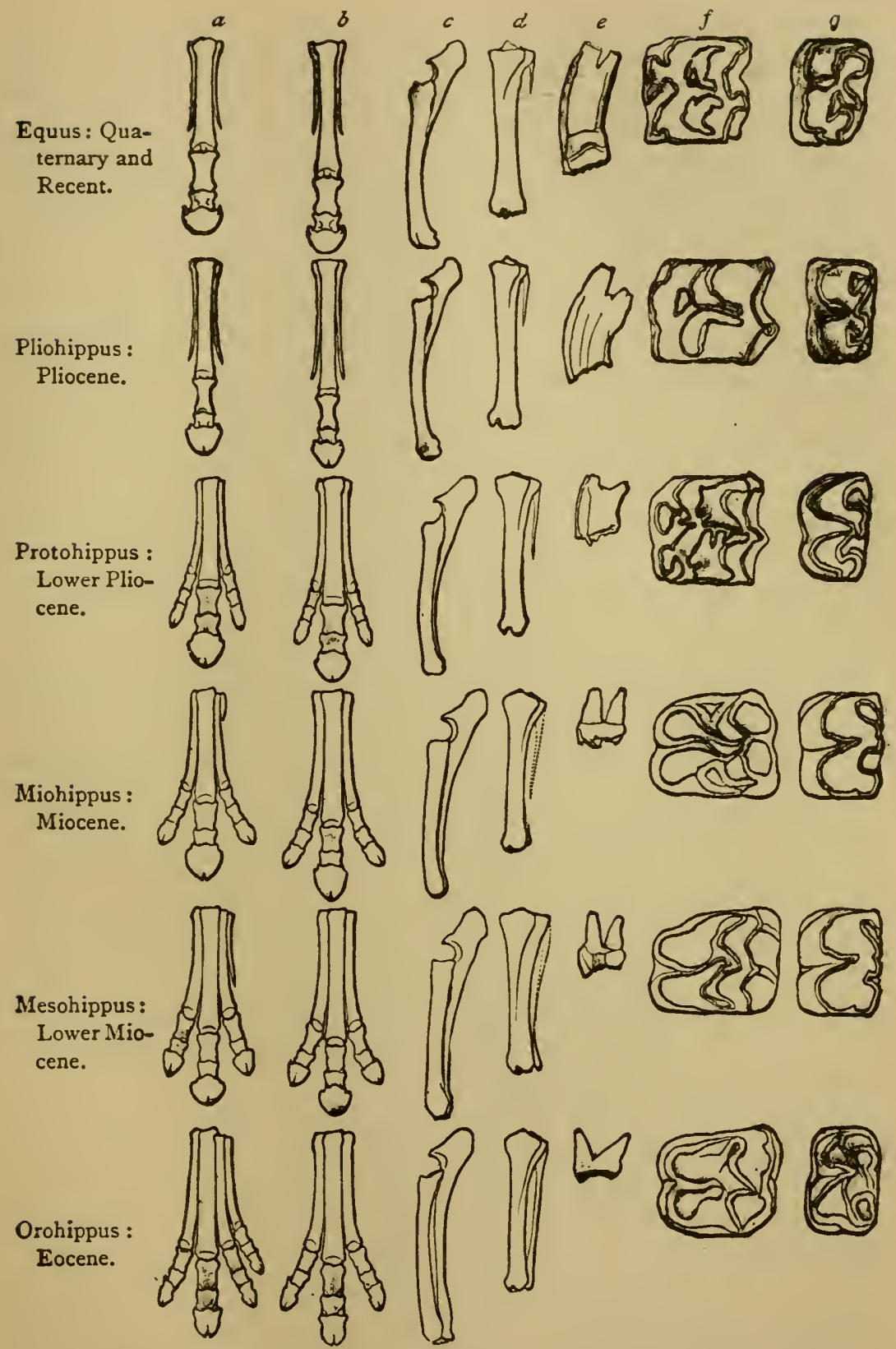

DIAGRAM illustrating the gradual evolution of the horse-family (after Professor Marsh),-kindly furnished by Messrs. D. Appleton \& Co. Throughout the series, $a$ indicates fore-foot; $b$, hind-foot; $c$, fore-arm ; $d$, shank ; $e$, molar, side-view; $f$ and $g$, grinding surface of upper and lower molars. The Eohippus of the Lower Eocene, and the Phenacodus (Cope), are not represented in this diagram. 
in the judgment of Professor Huxley, furnish an illustration of the truth of the doctrine of biological evolution, which renders it as well established as is the Copernican theory of the motions of the heavenly bodies. Beyond the Eohippus, an animal with four toes and an aborted fifth on its fore-feet, we have the Phenacolus, * a five-toed plantigrade animal, which is regarded as the original progenitor of the horse-family. 'The ancestor's of the European horse, which is supposed to have been introduced from Asia or Norther'n Africa, have also been discovered in the 'Tertiary deposits of the Eastern continents; but the pedigree of the horse is thus far most continuous in America. Strange to say, the line of ancestry of the European horse, unlike that of the American horse, has been traced back to the Palæotherium, also an ancestor of the tapir, and a connection of the pachyderms. It becomes an interesting question for future Palæontologists, whether the horse has really arisen by independent lines of succession from two different stocks, or whether his original home was not rather in America, whence he or his ancestors passed to Asia through the Arctic regions, when the two continents were united, and a milder climate in the Polar regions permitted such migrations. The development of this fruitful topic of the bearing of geological studies upon the question of biological evolution, belongs rather to the treatment of the evolution of vegetal and animal life. It is alluded to here merely to show how palæontology assists the geologist in accurately determining the order of geological succession, and corrects or sustains his conclusions in regard to those changes in the formation of continents and oceans, which have been going on since the world began.

It is proper for us to say here, however, that the succession of organic remains, in the geological strata, though not complete, is, so far as discovered, precisely what it should be to sustain the doctrine of organic evolution. The lowest orders of archaic life have not been identified in the stratified rocks; they probably never will be. They were too fragile - too easily destroyed by the operation of natural agencies. The lowest remains which we find are those of

* See "Origin of the Fittest," by Prof. E. D. Cope. A skeleton of the Phenacodus may be found in Prof. Cope's Collection, in Pliladelphia. 
the Eozoön Canadense* and Lingula of the Potsdam sandstone, on the borders of the Azoic period - the former, as claimed by Professor Dawson, possibly over the usually recognized line. How much below the Cambrian rocks life originally appeared, we do not know. Evidences, if they ever existed, have been destroyed by igneous agencies or otherwise. As we follow the scale of geological succession along up from the era in which these forms appeared, there are many " missing links" it is true, absent from our stone volumes, but many exceedingly suggestive links which are not missing. The pedigree of the horse constitutes one such indication, most interesting and instructive. Some of the later reptiles, also, have many of the characteristics of birds and mammals. The earliest birds were strangely reptilian in their characters. Some of them have teeth like reptiles and mammals. The evolution of life from the fish to the reptilian stage is indicated by the peculiarities of the remains of fish and reptiles belonging to the Carboniferous era. An outline of the order of zoölogical succession, as determined by the remains found in the rocks through the different geological periods, is suggestive of the completeness of the phylogenetic proof of the doctrine of organic evolution.

Duration of Geological Periods. That an enormous length of time must have been occupied by these processes of geological evolution is so evident as to demand no argument. A definite estimate of this time, however, is exceedingly difficult. It may be said, in general, that the tendency at the present day is to diminish somewhat the enormous periods of duration which have been assumed by modern geologists as necessary for the production of the observed geological changes. The time necessary for the Falls of Niagara to wear their way back from Lake Ontario to their present position has been variously estimated as 36,000 , $90,000,100,000$, even 200,000 years. Sir Charles Lyell estimated that they were wearing their way on an average of about a foot a year. But a very recent estimate reduces the time to $\tau, 000$ years. $\dagger$ Take even the last figures, which

\footnotetext{
* Geologists are not all agreed that the Eozoon of Professor Dawson is of organic origin.

$\dagger$ Niagara Falls must have originated since the most recent Glacial period, in a comparatively modern era, as the drift deposits everywhere underlie the riverdeposits between the Falls and Lake Ontario.
} 
are doubtless too small, and imagine, if you can, the time required for the Colorado river to wear its way down to its present bed at the bottom of a cañon 5,000 feet, in many places, below the level of the surrounding plain, through a rock harder than that of the Niagara chasm, and without the initiative force of the tremendous cataract, for a distance of six or seven hundred miles! This is one of the measuring sticks by which the estimate of the duration of geological periods is made. All such estimates, however, must be very imperfect guesses at the truth. The thickness of geological strata varies in different localities. The effect of local disturbances is such as to render it difficult to base an accurate estimate of time on such data as are obtainable. We can only say that immense, practically inconceivable periods of duration were requisite for the production of the observed effects. The present age of the earth has been variously estimated at from $25,000,000$ to $100,000,000$ years - the latter are Professor Geikie's figures. I suppose we might as well try to imagine one period as the other - both are so long as to be incomprehensible by the human mind. As Professor Le Conte affirms, such a period constitutes a practical eternity.

In conclusion, let me refer again to Le Conte's inspiring words : - "Until the birth of modern astronomy the intellectual space-horizon of the human mind was bounded substantially by the dimensions of our earth: sun, moon and stars, being but inconsiderable bodies circulating at a little listance about the earth, and for our behoof. Astronomy was then but the geometry of the curious lines traced by those wandering fires on the concave blackboard of heaven. IVith the first glance through a telescope, the phases of $\mathrm{Ve}$ nus and the satellites of Jupiter revealed clearly to the mind the existence of other worlds besides and like our own. In that moment the idea of infinite space, full of worlds like our own, was for the first time completely realized, and became thenceforth the heritage of man. In that moment the intellectual horizon of man was infinitely extended. So also, until the birth of geology, about the beginning of the present century, the intellectual time-horizon of the human mind was bounded by six thousand years. The discovery about that time of animal remains, all wholly different from those now inhabiting the earth, revealed the existence of other time fauma besides our own; and the idea 
of infinite time, of which the life of humanity is but an epoch, was then born in the mind of man; and again the intellectual horizon of man was intinitely extended. These two were the grandest idleas, and their introduction the grandest epochs, in the intellectual history of man"

When we note that all these processes of geological change have tended to diversify the earth's surface, - to produce variety in scenery, in climate, in vegetation, in fauna,when we see them followed by steadily increasing integration of structure and individuality of teature, in landscape and in organic life, we ramnot aroid the conclusion that the entire process of geological change has been one of erolution, obedient to the mandates of constant and invariable natural laws. And if we take the simplest integral product of this evolutionary process - a pebble from the sea-shore, or a mote of dust floating in the sim-kissed air — and trace back the causes which operated to bring it into its present condition; if we follow it through the action of all the forces, igneous, aqueous, atmospheric, that formed and disintegrated the primeval rock, back to the sum, whose heat set in motion all these terrestial agencies; back again, to the action of the cosmic forces that formed the worlds and sent. them spinning around their central orbs, - back still, to the distant systems of worlds, whinh, through the action of gravity, balance and sustain each other in their several courses through the infinite regions of space, - then, incleer, shall we realize that it takes the Infinite and Absolute fully to explain the smallest things. We shall see that the Persian aphorism but clothes the sober truth of science in poetic form, when it affirms that "God muketh of ever"/ atom of the Universe a mirror, and fronteth each with his perfect firee." 


\section{ABSTRACT OF THE DISCUSSION.}

\section{Professor W. Le Conte Stevens:-}

Evolution in its application to the genesis of our earth is a subject which now has but little, if any, theological bearing. We all know the mental agony through which Hugh Miller passed, in the vain effort to reconcile the biblical and geological accounts of the early development of our planet, the final effect of which was to deprive the world of an enthusiastie geologist, who became literally a victim of his own piety. In this discussion, the geologists won the field. To-day there are few pulpits in which the effort is made to teach literally what is contained in the first chapter of Genesis. The reconciliation attempted to-day rests upon a wide latitude in the use of language, and an inexactness of statement which is wonderfully comforting to those who can be satisfied with it. There is no such middle-ground, however, for us to accept, no reconciliation for our comfort. We must accept the Mosaic account exactly as it was written, or reject it utterly. For, if not inspired, it is of no more value than any other piece of mythology. With all veneration for the noble teachings contained in the pages of the bible, we kindly but firmly disregard it in every case where it is found open to attack on historical or scientific grounds.

But any conclusion that we may reach about the early development of the earth, even on a scientific basis, is necessarily largely speculative. It is impossible to insist too strongly upon the importance of limiting the intensity of our convictions, and of proclaiming that what we accept is merely an expression of probability. We accept the probability expressed in the nebular hypothesis, that the initial condition of our earth was that of a hot, saseous mass, containing all the elements now known to chemistry; and that every law of nature now based on the evidence of observation or experiment has been in foree throughout the indefinite past. It does not seem necessary to assume any universal diffusion of initial lieat. Let the law of gravitation be granted, and that matter was widely diffused in an indefinitely tenuous condition, at a temperature as low as that now pervading interplanetary space, several hundred degrees lower than that of our 
coldest winter weather. The assumption of absolute uniformity of diffusion would be contrary to all the evidences at present around us. If a single point is even infinitesimally denser than the matter surrounding it, this becomes a center of attraction. The aggregation of matter involves the arrest of motion; for particles moving toward the center are there stopped, but their energy is not destroyed. Mass motion is changed into that motion of molecules which is manifested as temperature. The greater the aggregation, the higher is the resulting temperature. Radiation also begins as soon as temperature is raised, but the rates of increase and loss of heat are not necessarily the same. Even after there ceases to be any sensible increase of matter aggregated from without, that which has been brought together tends to settle upon the center; and this continues the transformation of energy already manifested. The ill-defined mass of gas would gradually become viscous, until a condition of solidity would be reached, first at either the center where the pressure is greatest, or at the surface where radiation is fastest; most probably at the center. We have thus great central density with intense heat; around this the solid passes by insensible gradations into a viscous, tarry envelope, almost equally hot; this in turn as we pass outward becomes less viscous until a condition is reached like the average of what we now call liquids; but differing in this respect, that at first there is no well defined boundary between it and the densely gaseous materials which surround it. These in turn become thinner as we pass outward, the thimnest of all, hydrogen, forming the exterior envelope, which is devoid of any distinct bounding surface. Throughout the entire mass the heat is so great as to prevent.molecules of different kinds from coming within the range of chemical attraction. They are all beyond the limit of chemical association. But gravity is operative, and hence the elements of highest specific gravity, such as platinum, gold, mercury, etc., tend to aggregate at the center, while nitrogen, oxygen, and hydrogen remain near the boundary. We would thus have a mucleus of heavy, unoxidized material.

Cooling by radiation goes on most rapidly at the outer surface, so that here is the first place at which chemical activity begins to come into play. Hydrogen and oxygen unite to produce steam, but this is far beyond its condensing point, and is separated from outer cold space by a bed of still uncombined hydrogen. Long remaining in the gaseous state, it slowly penetrates downward by diffusion, mixing thus with the heavier nitrogen below. Sulphur also unites with oxygen, and chlorine with hydrogen, forming sul- 
phurous and hydrochloric acid gases; the former soon takes into composition the steam already formed, and sulphuric acid in great quantities is produced. Acid vapors therefore constitute a large and important part of the hot atmosphere. Beneath these the oxygen unites also with calcium, magnesium, silicon, aluminium, potassium, sodium, etc., producing a dry solid crust as a boundary between the hot liquid or viscous matter within and the hot mixture of gases without. It is well known that silica at very high temperature beliaves like an acid; it would therefore form silicates with the alkalies and alkaline earths just named. The free hydrogen is in time all used up in combination, and the cooling water-gas at the outside is reduced to its condensing point. It forms an envelope of clouds such as now float in the atmosphere of Jupiter and Saturn. With still further cooling these become precipitated as mist, which descends into the hotter regions below and becomes charged with acid. Reaching the solid crust some of it is re-vaporized with more or less explosive violence, and carries back to the outside the heat which has been imparted to it from the crust. At the same time the acids are largely taken up by the earthy and alkaline silicates, producing sulphates and chlorides. of these, while silica is precipitated. The silicates of iron and aluminium are not easily decomposed; hence the clays remain after the rest have been broken up into sulphates, chlorides and precipitated silica.

The law of diffusion of gases, though it never ceases to be operative, is generally masked by other laws. The process just described implies convection on an immense scale, so that diffusion may be largely thrown out of account after the first stages of condensation are passed. Acid rain-storms continually recur, assuming a degree of constancy and violence far in excess of anything conceivable at the earth's surface to-day. Meanwhile the cooling earth has been contracting unequally over different areas, according to the variation in conductivity of its materials for heat. Some large areas of the crust thus become regions of depression in comparison with those of less conductivity. When the surface temperature of the solid falls below the condensing point of the acid vapors, the rain falling on the hot ground dissolves all soluble compounds, and gathers into the great depressions, forming oceans of water that are from the outset strongly charged with salts. The leaching process continues even to the present day; but it is highly improbable that the saltness of the ocean, or even of inland seas, has been appreciably modified by the addition of 
salts soaked out from the neighboring soil within the present geological period.

One of the very widely diffused elements existing first in the gaseous state is carbon. Early in the evolutionary history of the earth, oxygen probably began to unite with it, forming carbon dioxide gas, which acted upon the exposed masses, forming carbonates of the alkalies and alkaline earths. The carbonates of calcium and magnesium are soluble only with great difficulty, while sulpliates and chlorides of the alkalies are leached out easily. Hence the bottoms of the oceans are now found to consist largely of impalpably fine sand, calcium-carbonate and magnesium-carbonate, independently of the subsequent production of calciumcarbonate by organic agencies or sedimentation. The work of the coral polyp is trifling in comparison with the chemical agencies operating long before conditions were such as to permit animal life of any kind. The subsequent crumpling of these areas is sufficient to account for the great mountain masses of primitive unstratified limestones and dolomites now so abundant. Crystalline marble could never have owed its origin to organic agencies.

Thjs then, in connection with the testimony of the stratified rocks, seems to be the story of creation as indicated by science, in contrast with the Mosaic accomnt. The two have no points of contact. If one be accepted the other must be rejected. The outline of development prior to the beginning of stratification may be called a mere speculation. Granting this, it is a speculation based on definite, well established grounds, and it has been elaborated by the best minds that have been active in the domain of chemistry and geology, such as Hunt, Forbes, Wurtz, Winchell, and Hitchcock. These anthors differ among themselves in matters of detail, but any one of them alone would be a better authority than all the writers of antiquity put together. Possibly, however, no intelligent reader to-day needs to be reminded that God's revelation to man may be as well through evolution as through any book for which inspiration is claimed. To discredit the Mosaic account may be like demolishing a man of straw. Whichever of the two we accept, we are still face to face with problems beyond human ken, and are forced to bow in humility before the Infinite. 



\section{EVOLUTION OF VEGETAL LIFE}

BY

WILLIAM POTTS 


\section{COLLATERAL READINGS SUGGESTED}

\section{CONAECTION WITH ESSAY T.}

Darwin's Origin of Species; Irariations of Plants and Animals under Domestication; Climbing and Insectivorous Plants; How Orchids are Fertilized; Cross and Self-Fertilization; Earth Worms. and Vegetable Mould; Gray's Darwiniana, and How Plants Grow; Nicholson's Palceontology; LeConte's Geology; Grant Allen's Evolutionist at Larye, and Colors of Flower's; Haeckel's Creation; Huxley's Physical Basis of Life, Lay Sermons, and Lectures on Evolntion; Spencer's Spontaneous Generation; Wallace's Island Life, and Tropical Nature; Clarke's Mind in Nature; Bastian and Tyndall on Spontaneous Generation; Powell's Our Heredity from God; Dawson's Geological History of Plants. 


\section{EVOLUTION OF VEGETAL LIFE.**}

Ix touching the question of development, even as it affects the most insignificant plant, we are feeling the pulse of the deepest mysteries:

"To me the meanest flower that blows can give

Thoughts that do often lie too deep for tears."

On the 26th of last July I was wandering around among the rocks where Cape Ann thrusts her granite arm out into the turbulent Atlantic, and bears from hour to hour through the ages the buffeting thunder-strokes of its mighty surf. The breeze was fresh; bright sunlight was reflected from the orange-gray rocks; and the air was full of the perfume of the bay-berry. But perhaps most lovely of all, where all was charming, was the myriad of wild roses which covered the bushes springing from the stony soil. We all know and love these delicate blossoms, which everywhere make our roadsides so attractive at midsummer. Professor Gray entmerates six species as growing in the Northern United States, and some varieties of these are to be found in almost every locality where there is a trace of wildness left. I have here roses from a bush of a different character, but we shall hardly say that they are less lovely. I want to ask you to follow me in an inquiry into the stages of the development of the bush from which they were taken; the different steps of growth which occurred before I could place before you these royal blossoms.

In what shape did it first appear as a growing plant? Probably as a short cutting from a branch, bearing a few buds, and inserted for a part of. its length in sandy loam: that is, it was simply a part of another bush. The bush from which it was taken doubtless originated in the same way, and so back for many generations, or quasi-generations,for, as a matter of fact, we have here no change by generation, but simply the prolongation of the life of a single

*. Copyrighr, 1889, by The New Ideal Publishing Co. 
plant, by cutting off the root, and bringing the branch into immediate contact with the soil and its contained fluids. By this means its life may be prolonged far beyond what is ordinarily its duration if left to grow from the original root, but not always, perhaps, beyond what is possible in such case: of a rose-bush still living at Heldersheim, in Germany, it is said that, $\$ 00$ years ago, Bishop Hepilo caused a trellis to be erected to support it.

For the purpose of my illustration, I can most safely go far back of the plant which produced the roses before us, and perhaps may as well take one of those in the thorns of which I became entangled by the margin of the sea. Those of you who are familiar with botany will pardon the introduction of some rudimentary facts, which are essential to the systematic development of the idea which I am to present to you.

We find, then, upon the summit of the flower stem, a little green urn or cup, dividing into five leafy points, and supporting upon its inner edge the five pink petals and a numerous colony of stamens crowned with yellow anthers; while within the cup are many tiny sacks, to each of which is attached a pistil having its summit slightly changed into what is called the stigma. When the flower is completely developed, we find that the anthers open and drop golden pollen-grains upon the stigmas below; and sufficient subsequent examination under a microscope shows us that from each live pollen-grain there grows a slender thread, which gradually penetrates to the little sack or ovule beneath. IVe next find formed, within the ovule, a minute cell: a membrane called cellulose, consisting chemically of carbon, oxygen and hydrogen, containing a semi-fluid drop of a substance called protoplasm, and consisting of the same elements, with the addition of nitrogen. I cannot tell you just how large this cell may be, but the ordinary diameter of cells in vegetable tissue varies between 1-240th and 1-1200th of an inch. If we take the largest of these, a cubic inch would contain about 14,000,000 of them. But. whatever its size, this cell carries the promise and the potency of the plant which is to be. It is not the primary form of vitalized matter, for this matter exists as mere protoplasm alone, without a membrane. In its earliest condition we should be unable to tell whether this protoplasm is the initial step in the formation of a microscopic being. 
not distinguishable either as plant or animal,-or whether it is to be a rose, a violet, a palm or an oak, - a worm, a fish, a lion or a man. Its future is absolutely unpredictable, and yet upon it have been impressed or within it are contained the influences which determine which of these forms it shall take, in what way it shall resemble other beings, and in what way be distinguished from them: whether it shall live a stationary life, rooted to a rock or to the soil,- - accepting the fate which the winds and the waters bring it,-or whether it shall have the power of flying to "fresh woods and pastures new"; whether it shall be a characterless automaton, or whether it shall speculate upon the origin of things, and upon life and death, the infinite and the absolute.

If we follow the changes in this cell, we find it gradually becoming larger, and dividing by a partition into two, into four, and so on, until a tissue is formed; into a substance having perceptible length, breadth and thickness. At last we recognize it as a seed: two minute leaflets attached to the rudiment of a stem, all enclosed within a surface membrane. This is now distinctly the beginning of a plant, and with numerous others it is contained within the orangecolored "hip." In this state it is quiescent, but if after a time we place it in the earth, we shortly find it burst its sheath: the stem lengthens and pushes downward; the leaflets, reaching toward the surface, separate, and from between them there rises a sprout. How is this done? Simply by the increase in size, and the multiplication of the cells already formed, by absorption of the necessary chemical constituents found in the soil. But these cells now have a more definite arrangement. Some form a white root, and some a stem also white, until it thrusts into the air and light the point of a leaf, which immediately takes a tint of green.

From this time on subsistence is not drawn from the soil alone, but from the air also. The leaf is not simply the right bower of the plant; it is its essential, I might say its only essential organ. There are, it is true, some plants which get along without leaves; such, for example, as the bright orange-colored dodder, common in our meadows and by the brooksides, trailing its long thread-like stems over shrubs and herbs, a golden network, with never a leaf, but with clusters of white blossoms. But these are lazy rogues, 
mere parasites, which do not even remain rooted in the ground, although they start there, but which attach themselves to other plants, and, too indolent to manufacture their own sap, plunder the vegetables, to which they have affixed themselves, of the material which they had provided for their own growth. There are numerous other plants not growing from the soil, such as the air-plants, with their gorgeous, or their fantastic insect or birdlike flowers; but these, to do them justice, are not so wholly idle and degraded: they are provided with leaves with which they earn their own living; they do not draw nourishment from the trees upon which they, are found, but merely use them for support.

As the cells become more numerous, they also become more and more diversified in structure. In different parts they are different in form, in size and in their nature; some are very beautiful; most are small, but others take the form of tubes, and are enormous, having a length in some instances as great as one-sixth of an inch! But this is an extreme case. The crude ingredients for the sustenance of the plant are absorbed by the root, and transferred from one closed cell to another, through many millions it may be, until they reach the leaves, where they are mixed with the constituents of the atmosphere, and elaborated into the protoplasm from which the plant is built up. The rapidity with which this transference may take place you have yourselves noticed, when you have taken a drooping flower and placed it in a vessel of water. How soon the stem, leaves and blossom regained their firmness, their rigidity, their elasticity, their "life"!

The plant now sends up a stem upon which appear buds; these unfold into leaves; branches grow from the axils of the leaves, and leaves appear upon these in turn, and thorns form, by which the plant is defended. A flower is no necessary part of a plant; it is but one means of providing for a continuance of the series. The flower itself is but a series of modifications of a cluster of leaves, some of which have become sepals, some petals, some stamens, and some pistils. At a recent meeting of the Royal Horticultural Society in London, an Alpine strawberry was shown in which all parts of the flower were more or less represented by leaves. The strawberry is a near relative, a sort of cousin-german as it were, of the rose. 
We have now completed the cycle. Starting from the flower, we have followed the life-steps until we have reached it again. Another course which we might have adopted, the one ordinarily chosen by fruit-growers, is that of budding or grafting. We should then have simply taken a single bud in the one case, a small twig in the other, from the variety which we desired to propagate, and inserted it into a sturdy stock of a nearly related kind, in which we had made an incision, bringing the inner bark into close contact, and excluding the air from the joint. What is the result. of this process? Excepting in a few special cases, which I cannot stop to describe, the line of union between the two growths becomes indeed a line of union, but remains a line of separation. It is like the door of the underworld of which Dante speaks, though perhaps the prospect is not so hopeless. Your quince or crab stock is firmly rooted in the ground; it draws thence its juices and transfers them from cell to cell, to those of the new bud; but here they "suffer" a sea change into something rich and strange." Your bud multiplies its cells,_- becomes a twig, - a branch; it buds, it blossoms, and instead of the woody but fragrant quince, the rosy but diminutive crab-apple, you gather the pearmain, the wine-sap, or the seek-no-further, as you may have elected.

But stop. Do you always gather a fruit exactly like that with which you were familiar? Do you invariably obtain from the seed or cutting of your rose a flower of the same identical tint - of the same form, of the same fragrance? Not so: you find slight differences, for the better or for the worse; scarcely any two are precisely alike; you choose those that you prefer and propagate them; you neglect the others.

We have seen that Gray enumerates six species of wild roses in the Northern United States. There are also a number of wild species in the Eastern Hemisphere - how many I cannot tell you. But their cultivation began at an early date, and they have been developed and crossed inextricably. In 1793 some wild Scotch roses were transplanted into a garden. One bore flowers slightly tinged with red; from this, double roses were developed, blush, crimson, purple, red, marbled, two colored, white and yellow, and differing as much in size and shape. In 1841 the number of varieties in the nursery-gardens near Glasgow was estimated 
at 300. In 1829, 2562 kinds of roses were enumerated as cultivated in France alone. Most cultivated roses have become double, and gradually less fertile, and less sure of reproduction in kind by seed, so that propagation by cuttings and by budding and grafting is resorted to, when the same characteristics are desired. Our apples belong to the rosefirmily. You know how much they vary. If they do not all come from the common crab, there are no wild species living, or of which there is any trace, resembling the present forms, and these are continually being increased in number.

This may be as good a time as any, to speak of another variation, - a variation which sometimes occurs immediately in the fruit produced from the pollen of one plant when placed upon the flower of another, and not simply as seen in the fruit of a plant resulting from seed so produced. As an illustration of this, I will give a single instance.

At St. Valery in France there is an apple-tree which has blossoms with a double calyx having ten divisions, and with fourteen styles, but without corolla or stamens. The flowers therefore require artificial fertilization with pollen from another tree. The girls of the village go annually to "fuire ses pommes," - to make their apples, each marking her own fruit with a ribbon, and as different pollen is used, the fruit differs on the tree. This is an exceptional case, but the same thing has occurred where the conditions were not so unusual.

Almonds, pears, peaches, plums, cherries, nectarines, etc., belong to the rose-family. The peach is believed to have been derived from the almond, and the nectarine is supposed to have grown from a peach-stone, in Boston, England. It is certain that peach-trees frequently produce nectarines, while nectarines at times produce peaches, sometimes both kinds of fruit appearing together on the tree. Occasionally a part of a single fruit is peach, and a part nectarine. You know what a vast difference there is in the varieties of grapes. Most of these are supposed to have risen from a single Asiatic species. Of gooseberries there were eight varieties known in 1629; now there are over 300 .

Pansies are believed to have been derived from five wild stocks, variously crossed. You are all familiar with their varieties and differences. Dahlias are believed to have all 
come from one species since 1802 in France and 1804 in England. With the varieties of these you are likewise familiar. So also with the hyacinths. The original flower, which was brought from the East, had the petals narrow, wrinkled, pointed, and of a flimsy texture. In 1597 there were four varieties; in 1629 there were eight; in 1768 there were said to be nearly 2000 . The number has since, it is believed, very much decreased. Of chrysanthemums, "it is said that at least 10,000 seedlings have been exhibited for the first time this year. The diversity of form and color displayed is almost infinite, and the varions strains have been so intercrossed that the seeds from a single flowerhead will often produce examples of the types most widely separated in structure and size, together with intermediate and kindred forms."

These numerous varieties have been produced first by unconscious, then by conscious as well as by unconscious selection. The least of a botanist among us knows enough to gather the finest cluster of mayflowers which she may find by brushing away the dry leaves with which they are covered in the early spring; the best huckleberries or blueberries that grow upon the mountain top. We all know that there is a difference. So in the orchard or in the garden. If there are too many apple-trees, it is not those which bear the finest apples which will be sacrificed; if the rosebushes need protection from the frost, it is not those which produce the smallest and the most scentless blossoms that will be most tenderly cared for. We know, too, that as we give a more steady supply of moisture and nourishment to the plants which we protect, they improve in quality and increase in variety. How they will vary, at the outset we do not know, nor do we know when they will vary. But experience has shown us that they will vary, and that by protecting such varieties as please us most, and propagating them, and conversely, by neglecting or destroying those which are less satisfactory, the variations once begun can be increased and made definite upon the lines chosen.

From this elementary condition, cultivation has gone forward until it has become the artistic representative of a science, and until it almost seems that due diligence only is required to enable the floriculturist to turn out a flower of any pattern which may be suggested to him.

It must be borne in mind however, that these results are 
frequently attained under conditions which are artificial, and which are dependent upon the continued care and attention of the operator. From this it would naturally be inferred that the elaborate productions of the culturist's art, if left to themselves, would either perish from the too cold charities of the common world, or would rapidly change their character, and if they did not return toward the form from which they were derived, would at least become something quite different from that to which they had been trained,- - and this is frequently, if not always, found to be the case. I have been particularly interested in noticing the apple-trees growing among the trees of the forest, by the side of country roads: not merely the fruit is different from what it should have been, but the whole character of the tree is changed. The branches, instead of being few and wide-reaching, have become numerous, ascending, frequently divided, angular, and with twigs short and thorny.

Strictly speaking, an organism is that which has organs. Colloquially, however, when we speak of organic life, we use the term in contradistinction from mineral, which we call inorganic. As we have seen, the lowest form of matter of which we speak as living, is composed of carbon, oxygen, hydrogen and nitrogen, which are also found in compounds not termed organic. What, then, is the distinction between the organic and the inorganic, and how and when did this distinction arise?

Huxley gives three points, in which he claims that that which has life differs from that which has not life. First: In its chemical composition; the chemical elements are united in a combination called proteine, which, together with a large proportion of water, forms protoplasm. Proteine, it is said, has never yet been found except as a product of living bodies. Second: Its universal disintegration and waste by oxidation, and its reintegration by the reception of new matter. Third: Its tendency to undergo cyclical changes - that is, to pass through a course of development and decay in a succession of forms, like and unlike.

Probably at the outset many persons would say that motion and growth are the most characteristic attributes of life. But the mineral compounds show both motion and growth. Certainly few things are more definite or beautiful than the growth, of course accompanied by motion, which occurs in 
the formation of crystals, and which is shown us in transcendently lovely forms in the frost-work upon our windows upon a winter morning.

It is a most interesting question whether the forces which produce organic life differ from those so-called physical forces with which we are familiar in other phenomena. It is clear that all the complicated processes which we call "vital" in ourselves and other higher organisms, are invariably found in the closest and most intimate relations, apparently of effect and cause, with light, heat, electricity, etc. Modern science has shown these forces to be equivalent, correlative and interconvertible, and it would seem an excess of stupidity did we not mentally connect the elaborate operations which we know with the simpler ones which preceded them, as alike in nature and origin. However we may define it, we are certainly, at present, forced to recognize a distinction between that which we say has life, and that which we say is without life. But this distinction, this parting of the ways, finds us upon a narrow edge. On the side of life, we have an unorganized albuminous substance without definite size, or form, or boundaries, - simply homogeneous matter of intimately united carbon, hydrogen, oxygen and nitrogen. I should note here that Huxley remarks: "It may be safely said of all those living things which are large enough to enable us to trust the evidence of microscopes, that they are heterogeneous optically, and that their different parts, and especially the surface-layer, as contrasted with the interior, differ physically and chemically." He does not, however, mean by this that the difference extends so far as to constitute organs.

How the differentiation between the living and the notliving took place, who shall say? All that we know at present is, that it did take place, or that at some time it was, and that among the qualities of which so-called organic matter was then possessed, or which at least it has always exhibited since it has been observed by men, were the capacity for change, and the power of transforming inorganic into organic matter.

Protoplasm in masses, as discovered at the bottom of the sea by the Challenger expedition, was described by Huxley under the name of Bathybius. Of the same composition we find perhaps the lowest forms of individual life, in what 
are called monera;-simple tiny lumps of protoplasm, which have no containing membrane. Their motion consists in a changing of shape by the protrusion and retraction of certain parts, not differing in structure from other parts, and they multiply in a most unmathematical way, by dividing. Are they animal? Are they vegetable? Are they not rather a division antecedent to these, and one which cannot be classed with either of the great kingdoms, which probably diverged from it? Haeckel, with a considerable show of reason, takes the latter position, at least tentatively.

These, and the nearest allied forms, are generally microscopic; some may be said to have organization - there is a certain differentiation of parts; they have motion; some of them, such as the diatomaceæ, have silicious shells or skeletons, with wonderfully beautiful markings. That you might have some perception of the subtility of nature's handiwork, I should like to show you through my microscope a specimen of one of the species of these. You would see a tiny vessel, for all the world like a canoe turned bottom upward (as I have a chilly remembrance of mine having been once, with myself atop, under the gentle ministrations of a September gale in New York harbor), only with stem and stern gracefully curved sidewise in opposite directions, and regularly marked diagonally from point to point with almost innumerable parallel lines in two series, nearly at right angles. It is magnified 500 diameters, - that is, within the space apparently occupied, could be placed 250,000 of the actual diatoms. Mr. McAllister tells me that he has seen the same object under a magnifying power of 100,000 diameters, or covering seemingly a surface which would enclose ten billions (or, what is the same thing, 10,000 millions) of the vegetable, if vegetable we are to call it. Of course but an extremely small fraction of the object can thus be examined at one time. Under this power, the simple parallel lines become the intersecting paths between continuous rows of hemispherical projections.

Notwithstanding their shells, and notwithstanding their motion, these are usually accounted vegetable. Indeed, it is difficult to find any test by which that which is animal may be separated absolutely from that which is vegetable. Is it incongruous for a vegetable to have a solid mineral 
frame-work like that of the diatoms? The Rev. J. G. Wood says of flint in grasses and in the horse-tails or equisetæ, "so plentiful is this substance, and so equally is it distributed, that it can be separated by heat or acids from the vegetable parts of the plant, and will still preserve the form of the original cuticle with its cell-walls, stomata and hairs perfectly well defined." Is it strange that a plant should have motion? Darwin has shown, by multitudinous experiments, that many climbing-plants regularly revolve at their growing ends, from right to left, or from left to right; that these revolutions are made in specific times; that their tendrils, when they have them, likewise revolve, and move forward to avoid clasping the stems upon which they grow; that sometimes, even if touched on one side by a weight no greater than 1-50 0th of a grain, they will curve toward that side, and subsequently become relaxed; that when they find a suitable object, they will twine around it, and having fastened themselves securely, draw up into a spiral spring, thus holding the plant more safely to its support, and at the same time providing a method by which it can yield to the pressure of the wind without disaster.

Is it in the character of their food? It used to be said that animals could only subsist upon organic matter provided by vegetables, either immediately, or indirectly through the substance of other animals, while vegetables drew their nourishment only from air, earth and water, elaborating organic from inorganic matter. But here again we were at fault. I am the happy possessor of a few rocky acres in the north-eastern corner of Connecticut. At the foot of my slope is a pond, with a meadow and a stretch of marshy ground rich in flowers of many sorts. Among these is the beautiful sundew, with its little round or oval leaves, covered with slender hairs, each holding upon its summit a pure and brilliant ruby drop. There it lies in wait to catch incautious insects, ants or flies, and when once they have ventured upon its shining trap, gently folds them in and holds them in a close embrace, until all their available substance has been absorbed. There, also, in hundreds, - yes, in thousands, - is the curious pitcher-plant, always holding out its cups to catch unwary stragglers, and then using the same cups in which to prepare them for its daily meal. In the South there are other species of these, which have a sugary trail leading over the edge of the cups 
and so down to the ground,- - a long and narrow road to perdition for uneducated or too dissipated insects. There, also, are the Venus' fly-traps, - more ambitious relatives of the sundew, - greedy plants, which are not always cautious enough about what they attempt to devour. It is said that one of them, being fed by a waggish investigator with a piece of cheese, had a most disagreeable dyspepsia therefrom.

Mr. W. T. Thistleton Dyer, in the "Encyclopædia Britamica," draws this distinction between animals and plants : "If we compare a plant and animal reduced to their simplest terms, and consisting therefore in each case of a single cell, i. e. of a minute mass of protoplasm invested with a cell-wall, while the unicellular plant draws its nutriment by simple imbibition through the cell-wall from the surrounding medium, - a process which implies that all its nutriment passes into it in a liquid form, - the unicellular animal is able to take in solid nutriment by means of intermptions in the continuity of the cell-wall, and is also able afterwards to reduce this solid food, if of a suitable composition, to the liquid state.".

We do not have to go very far above the monera to find what we may safely call vegetable forms. And first we discover, for example, the protococcus, "which forms dull crimson patches resembling blood-stains on the northern side of damp rocks or old walls," - plants of a single cell, of which Haeckel says, "several hundred thousand occupy a space no larger than a pin's head." They belong to the algæ or tangles; and, while these are perhaps the smallest, within the same division at the other end of the scale we find the largest plants, the macrocysts, 300 or 400 feet in length. With the algæ of the sea, in some form, we are most of us familiar, and many of the species which we find upon the shore, where they have been left stranded by the tide, are exceedingly beautiful. It is noteworthy, that some algæ have been found living in hot-springs at a temperature as high as 208 degrees Fahr.,- a quite exceptional condition of life.

Nearly related to the algæ, are the fungi and lichens, the algæ being distinguished from the others by containing chlorophyll, that is, the substance which gives the green color which we see in most plants, and which is supposed to be the principal instrument in the elaboration of the nu- 
triment upon which the plant subsists. Among the fungi are the bacteria, the yeast-plants, the bread-moulds, the cheese-moulds, mushrooms, toadstools, rust, smut, and a vast number of others of a related character. These, as is the case with most of the lower forms of life, multiply with enormous rapidity. 'Together, the algæ, fungi and lichens form the sub-kingdom called Thallophyta, the characteristic of which is that the plants are without distinct diferentiation of root, stem and lateral appendages.

Another sub-kingdom,-Cormophyta,_- embraces the remaining vegetable population, which may be arranged approximately in the order of development or of elaboration, thus: mosses and liverworts; ferns; the equisetæ or horsetails; the lycopodiums or club-mosses and their near relations: then the flowering plants, beginning with the coniferr, - the pines, firs, cypresses, yews, and the cycas, which have naked seeds, usually in cones, - and ending with the multitude of trees, shrubs and herbs having their seeds enclosed in seed-vessels, and divided into those the stems of which increase in size by additions throughout their thickness, like the palms among trees, and the lilies among herbs, and those which ircrease in size by growth on the exterior of the wood immediately under the bark-thus showing year-marks if they be perennials; this division including such trees as the oak, and such herbs as the violet.

While differing enormously among themselves in every respect except one, the leading difference which runs through this classification is in the method of reproduction, and the structure of the reproductive organs. In the very lowest plant-forms, multiplication seems to depend simply upon the strength of the cell membrane. The single cell increases in size, and a partition is formed across it. If the membrane be weak, the two cells part company, and the number of that species has been doubled. If the membrane be strong, the two cells remain attached, and the process of increase in size and division may continue. The protoplasm of the unicellular plant is frequently broken into fragments, each provided with cilia or filamentous prolongations of the protoplasm, by the aid of which they move rapidly through the water in which they are formed. Gradually each becomes corered with a coating of cellulose, and begins life as a complete plant. Much higher in the scale of vegetation, the power of increase by simple sub-division 
is retained, as we have seen in the propagation by cuttings. A more marked instance is to be found in the case of the begonia, which the florists propagate from fragments of the leaves. In some of the garden lilies, perfect bulbs are formed in the axils of the leaves; in other plants, bulbs are formed under ground; in the potato, large stems or tubers are formed upon the roots, and from these new plants are grown.

In the simplest plants formed of aggregations of cells, the independence of the cells seems to be simply limited by their physical attachment to each other; subsequently the functions of the parts become diversified, and a division of labor begins.

The next form of the reproductive process is found in the desmids and diatoms, which, beside multiplying by division, also multiply by conjugation; that is, two cells or plants unite to form a compound plant, the contents of which, taking upon itself a coat of cellulose, begins a new series of individuals. The next is a differentiation in the structure of the plant by means of which certain cells called antheridia, produce antherozoids, which correspond with the grains. of pollen in the higher plants, and other cells produce oöspheres which correspond with the protoplasmic contents of the ovules. Then we come to the mosses, which have processes resembling pistils and antheridia, either on the same, or on separate plants. Then ferns, in which the spores, found upon the underside of the fronds or leaves, drop off when ripe, and produce minute plantlets, which contain separate elements which must unite before fertilization is effected. Above this grade are the flowering plants, in which is more or less developed the complete system which I have described in the case of the rose.

In much the greater number of the plants with which we are familiar, the stamens and pistils are found in the same flower; sometimes they are found in different flowers upon the same plant; sometimes some of the flowers upon a plant are perfect, and some are staminate or pistillate only; and sometimes the staminate or pistillate flowers are found upon separate plants. The last form is esteemed the most highly developed. I should note in passing that while in all the higher orders of plants having flowers with stamens and pistils, fertilization seems to be necessary for the maintenance of the race, nevertheless instances have been occa- 
sionally observed, in which perfect seeds appear to have been formed without fertilization.

I have said that the leaf is the essential organ of a perfect plant. Many plants consist only of the leaf. Rising above this stage, and reaching that of a stem, with root and lateral appendages, we still find the leaf the most important feature, and upon it is dependent the character of the plant. The leaves appear upon the stem in certain specific relations. They are opposite, or in a whorl around the stem, or with the stem passing through them, or placed like a shield upon its summit, or arranged alternately upon its sides. If alternate, they are arranged in certain spirals, as, in one turn with two leaves, or one turn with three leaves, or two turns with five leaves, or three turns with eight leaves, or five turns with thirteen leaves, etc., before a point is reached exactly above that of starting. Sometimes, instead of their ordinary form, leaves assume those of bracts, of scales, as in buds, of tendrils, of spines, etc., and, as we have already seen, of the various parts of flowers. In flowers they exhibit almost every conceivable variety of form and color: sometimes there is one, sometimes there are two floral envelopes, their leaflets united or separate, few or many; sometimes there are stamens and pistils ; sometimes either; sometimes none; sometimes the flower is regular in shape; sometimes irregular, in one or other direction,- - any one of the parts occasionally reverting to its normal form as a simple leaf. As the branches usually appear at the axils of the leaves, the arrangement of the branches is governed by that of the leaves.

I have said that plants differ in structure in every respect except one. That one is the cell. As the individual plant starts with a single cell, and, simply by aggregation of cells growing from this one, obtains at last all its varied parts as a perfect whole, so the vegetable kingdom throughout, from the simplest form to the most complex, is but a series of similar aggregations. Under the development hypothesis it is claimed that these forms are of a common stock; are related to each other by lines of descent, all having probably originated in the unicellular "aggregation of protoplasm which I have described. As we cannot say how this became differentiated from inorganic matter, so we cannot positively say whether such differentiation can now take place. The problem of spontaneous generation is one to which 
much time and thought and careful experiment have been given.

Not many year's ago it was supposed that the development of infusoria in water, in which organic matter had been steeped; the swarming of animal and vegetable life in decaying organic matter of all kinds, and where no organic matter was known to exist, and great caution had been used in experimentation, - and other similar facts, - were proof positive that such life may even now be generated spontaneously. But then followed an enormous increase in the precision and care with which experiments could be conducted, and it was believed by most that when all access of the germ-laden air had been made impossible, and other essential conditions had been fulfilled, no such generation occurred. Subsequent investigation made this again uncertain. I have an impression that some one has said, - if not, some one will say, - that the struggle here is like that between the manufacturers of big guns, and the builders of mail-clad vessels. As to spontaneous generation at the present time, we can hardly do more than render the Scotch verdict,"not proven." But if it does not now occur, it does not therefore follow that in the long-buried past the conditions may not have been such as to have permitted this.

In this connection, the theory that the parts of an individual, such as a tree or the individual cells of even complex organisms, may have some sort of independent existence, is most interesting.

Supposing the development theory to be correct, it is to be assumed that the earliest forms of vegetable and animal life must have been the simplest - mere albuminous matter. No such forms are found in the geological record: it is impossible that they should be,-their substance and organization (if we may use such a term) were such that they must inevitably be annihilated by time and mechanical action. Moreover, all the earlier rocks appear to have been exposed to such heat and pressure as must unquestionably have destroyed much more elaborated tissues than those first formed. Even should we ever obtain access to that portion of the record now concealed in the bowels of the earth, or under the waters of the sea, there is scarcely a possibility that we should find evidence of the earliest forms of life. Moreover, we could not expect to find a regular series of forms. Between those deposits in which vegetable remains 
are preserved there are the widest gaps. They were usually laid down upon sea-bottoms, or in shallow lakes, or at the mouths of rivers, and vast intervals of upheaval occurred between them. There were also great changes in temperature, and by climatic influences, and the varying connections of islands and continents, alternately elevated and depressed, tribes have been pent within narrow limits, or spread to the four quarters of the globe. Nevertheless, in general, the story that geology tells is the story that we should expect to hear. In the several great geologic periods, evidences of the vegetable life of which have been preserved, certain plant-forms have dominated in turn, and in the order of their complexity as I have already defined them.

First appeared the algæ, in the Primordial Epoch, and with them, apparently, no other. In the Primary Epoch, in which were made the great coal deposits of the Carboniferous Period, there was an enormous development of mosses, of lycopodiums, of equisetæ $\sim r$ horsetails, and of giant ferns in great variety and of great beauty. So far as many of these exist to-day, they are characteristic growths of warm countries. It is noteworthy that plant-life was the dominant life of the Carboniferous Period; that plants grow most luxuriantly in an atmosphere containing an excess of carbonic-acid gas; that the effect of such an atmosphere would be to greatly raise the temperature of the surface of the globe; and that during the Carboniferous Period, this tropical vegetation seems to have been spread throughout the circum-polar regions. If, then, at this period, there was an excess of carbonic-acid gas in the earth's atmosphere, all the facts which we note are harmoniously accounted for.

The latter part of the Primary Epoch and the beginning of the Secondary, saw the development and reign of the palm-ferns and the pines; and then the palms and similar interior growing plants; and finally, in the Tertiary and Todern Epochs, became dominant the hard wood trees and varied flora that now in great part form the royal fittings of the temple of nature in which we dwell. Of old herbaceous forms the remains are, naturally, relatively few, because of the softness of their substance; but so far as they appear, their character corresponds with that of the general record.

I do not mean that all of our present forms are very re. cent. On.the contrary, though not among the earliest, some 
of them were developed long ago, and when vegetation $g \in=-$ erally was of a simpler character. Take for instance the sequoias, once numerous, of which there are now but two living species, both on the Pacific slope, and of which giant trees it used to be said that it required two men and a boy to see to the top of one of them. Nor do I mean that none of our present forms are simple and primary. I have already shown you that the case is quite different. But, as we shall see, there is not only no incongruity in this; on the contrary, it is in strict accordance with the theory which I am attenpting to illustrate.

The theory of Evolution, as portrayed by Spencer, describes a progress from the homogeneous to the heterogeneous ; from the all-alike, to the greatly varied. This does not necessarity imply advance in one direction. The contribution of Darwin to this theory was the proposition of a condition, of an active agent, and of the method of its operation; the struggle for existence, natural selection, and the survival of the fittest: of the fittest, mark you, to comply with the conditions existing, - not fittest in the sense of best, which is the interpretation usually put upon the term by those who have not made the matter a study. We have here however a good illustration of the saying that there is always room at the top. The greater the variety, the more certain it is that with complexity of form will come advance on certain lines, because, upward and outward, the possibilities are infinite.

Darwin claimed, modestly but firmly, that the one named by him was the principal, though not necessarily the only cause of the development of all existing animal and vegetable life from simple primary forms. If you have not thought carefully of the matter, perhaps you have not realized that there is any such thing as a struggle for existence in organic life, although those of you who have tackled the world single-handed may perhaps be inclined to make an exception in your own case. Let us see : a few suggestions, only, will suffice.

Experiment has shown that the air contains germs in great variety, in numbers inconceivable. So also the soil. Darwin took three table-spoonfuls of mud, from three different points beneath water on the edge of a little pond, and, placing it under cover in his study, kept it there for six months, pulling up and counting each plant as it grew. 
There were 537 of them! But one other case will tell the whole story. Darwin counted and estimated the seeds of one of the English orchids - orchis maculata: there were 186,000. Taking into account the size of the plant, he found by calculation that if these seeds should all grow, 174,000 of them would be sufficient to cover an acre; that is, in one generation, or one year, the fruit of a single plant would be sufficient to cover an acre; in two, sufficient to cover the island of Anglesea; in three to cover 47-50ths, or nearly the whole, of the surface of the earth! Yet this plant is not increasing in number : not more than one, then, out of 186,000 of its seeds, is able to maintain itself to the point of producing other seeds, and carrying on the line.

Seeing that such is the condition of life,- that all the "soft places" must be taken almost at the moment the door's are opened, and that standing-room only is to be found by the few that are ready to take the places of those that from time to time fall out of the ranks, is it not inevitable that the slightest advantage in any conceivable direction will be favorable, and that the plant having this advantage will be the one that will live and perfect its seed?

We have seen that slight variations are the rule in nature. These variations may take any direction. If there are upon a given space all the tall plants that can there find room, smaller ones only can creep in, and vice versa. If all the material required by complicated organisms is already spoken for, those only that can live on an inferior quality can find a chance to exist. There are all possible gradations of these conditions. Experience shows that a spot of ground sown with the seeds of several genera of grasses, will produce a greater number of plants, and greater weight of herbage, than a similar spot sown with a single species. Darwin found on a piece of turf, three feet by four, which had been left for many years under similar conditions, plants of twenty species, from eighteen genera and eight orders, showing a wide difference in character.

Time will not permit me to even enter upon the details which have been gathered illustrating the nature of this struggle for position, which is incessantly going on, or the evidences of its effect, excepting possibly in a single direction. I should like to explain Darwin's hypothesis of Pangenesis. I should like to show you how seeds and plants are distributed: borne on the wings of the wind; carried in 
the crops or between the toes of birds ; floated across waters in old tree-trunks and timbers, or shipped unwittungly in the meshes of sacks or cracks of packing-boxes. I should like to tell how our most troublesome weeds, like the whiteweed, or so-called daisy, wnich trades upon the reputation of the "wee, modest, crimson-tippit flower," and a host of others, are pauper-immigrants, - some of them anarchists, indeed,-naturalized and voters the first year, every one. Against them, high license, local option, and prohibition have been alike unavailing: the American System of Protection has been an utter failure. I should like also to show you the minute degrees by which great changes are usually effected, but perhaps this has been sufficiently done in what I have said in relation to Artificial Selection. Natural Selection is simply the happening, under ordinary conditions, of that which man effects under extraordinary conditions. It is simply that which must result, in the nature of things, from the fact that a small fraction only of the whole can survive; and from the two diverse tendencies in the laws of descent, for like to produce like, and for the child to differ slightly from the parent. Of course the enormous extent of the changes presupposes an enormous lapse of time in which they were effected. But that lapse of time geology shows to have occurred.

I will only mention one part of the evidence of adaptation which has been recorded. The conviction was forced upon Darwin's mind, by the results of an immense amount of research, that persistent inbreeding is probably detrimental to any plant: that strength results from the crossing of individuals, if not of varieties or species; and that, with a higher grade in life, comes an increasing tendency to specialization in the reproductive organs, and the interposition of bars to self-fertilization. His most exhaustive study was made among orchids, of which there are some 6000 species. Many of these are epiphytes, or air-plants, and are marked by the strangeness or magnificence of their blossoms. They are also marked by a wonderful tendency to hybridize, which enables florists from month to month to exhibit new forms and colors, sometimes of woudrous beauty, and therefore, I imagine, not closely resembling the dog for which the boy wanted an extra price, because he comprised sixteen different kinds.

Darwin found that in nearly all orchids it is impossible 
for the pollen of a plant to reach the stigma of the same, but that fertilization is effected by bees, butterflies, and other insects, which bring pollen from other plants while seeking for nectar, the flowers being usually so constructed as to make it impracticable for them to withdraw without carrying away the pollen-masses from the anthers, or to enter the nectaries of other flowers without placing these masses upon the stigmas. The book in which he explains this process, you will find most fascinating.

Among the trees upon my rocky hillside, I found last summer numerous specimens of a showy, rose-purple orchid,-- one of the Cypripediums, - called indifferently, wild lady-slipper, Noah's-ark, or moccasin flower. If I were to tell the whole truth, I might have to confess that it was partly because of its presence that I was induced to buy the property. This belongs to a genus which Darwin believes, from its structure, to have been one of the earlier forms, in which the fertilization of the flower by its own pollen, or that of another plant, depends upon whether the insect enters it first by one of the side notches or by that in the middle. In most orchids, there is no option,- the flower must be fertilized from another; and this is the case with one of the most attractive of the smaller species, the lovely little white spiranthes, or ladies'-tresses, of our meadows.

Perhaps I might venture to mention just one other instance of complicated relations, of especial interest to our single sisters. Darwin found that the fertilization of red clover depends largely, if not solely, upon the visits of humble-bees; that the number of bees is greatly reduced in a district where field-mice are numerous; and that the number of field-mice is dependent upon the number of cats. Huxley carries the chain one link further, and throws out. the suggestion that it is the abundance, or otherwise, of the old-maids who cherish the cats, upon which rests the fate of the red clover,- and indeed, as Carl Vogt says, the fate of the English race, whose staple food is the beef grown from the red clover. So you see that starting with the women, by a devious course we reach the men at last.

Why do these changes of form occur? I cannot tell you : no man can to-day tell you. We only know that variations are constantly taking place; that one form is developed from another; that these variations result from tendencies. 
controlling the organic matter, checked and guided by surrounding conditions. We know that these changes occur, as certainly as we can possibly know anything: they are taking place at avery instant before our eyes. Whether all changes have been of the same character; whether all forms of life, above the most simple, have come from pre-existing Iorms, we cannot now prove,_- we can probably never prove. The most that we can say is, that the preponderance of evidence in this direction is overwhelming; that the system thus outlined is consistent and reasonable; and that any other system or theory, which has so far been broached, seems arbitrary, artificial and improbable. We cannot say that we can understand it, excepting as a logical process: our minds as developed so far have not capacity for grasping certain ideas, which nevertheless we can express. Whatever theory of creation we may accept, whichever horn of the great dilemma we may adopt, - as, for example, that there was a point which had no antecedent, or that there was no such point, - we are alike landed in the inconceivable : and yet, the inconceivable on the one hand or the other, must be the true. This is not saying that we must not speculate; it is simply saying that from the constitution of the mind speculation has its limits, which we shall reach, and which will bring us to a halt willy-nilly: we need not fear lest we transcend these limits; we cannot overstep the boundary until our minds take on new powers. We shall adopt, and properly adopt, that theory which is in closest accord with what our experience shows us to be the facts; that theory which requires us to make the least draft upon the arbitrary and the cataclysmic.

Some weeks ago there appeared, among the waifs in one of our daily papers, the following story: "It is said that when Gen. Grant was in Japan, the Japanese Premier, Prince Kung, desiring to compliment the General by telling him that he was born to command, tried it in English with this result: 'Sire, brave General, you vas made to order.'" Apparently, in most quarters to-day, as in the past, the great question is, whether things have been made to order. The question of design has been the vital question, whether Paley has been the spokesman upon the one side or Haeckel the spokesman upon the other. During the contest through which the development hypothesis passed before its generai acceptance by the great body of scientific men, this ques- 
tion of design was probably the principal stumbling-block, and many shades of theory have been advanced, ranging from the idea of an absolute pre-existent plan, carried out with mechanical exactness by a divine artificer residing afar, to that of the occurrence of purely fortuitous and unintended combinations. The latter is that of Haeckel, who supposes all development to result from what he calls natural causes and mechanical laws, without any participation of divine power. But whence come these "natural causes" and "mechanical laws" he fails to explain, and he likewise fails to explain how he knows that no divine power is involved.

It seems to me that there is a different way of apprehending the universe, which accords with the facts more nearly than any of these, from the most orthodox to the most materialistic; and it is the natural outcome of the idea of the one-ness of things carried to its $n^{\text {th }}$ power, - to its ultimate.

We know nothing of spirit, except as we find it manifested through matter: we know nothing of matter except as spirit makes it objective. We know nothing of absolute life, except as we see it manifested in ourselves, or in that which is around us, or in that which what is around us and in us records. We know nothing of a primary fiat; we know only development and change. Why should we turu our backs upon that which we know, to guess at that which we do not know, and cannot possibly prove? Why choose an arbitrary theory while the facts before us all point in one direction?

We talk of "natural laws" and "divine laws." We know nothing of the imposition of such laws, - we can know nothing. All that we mean by these expressions is, that we are conscious of an invariable sequence. The Universe holds together: there is no revolt in that which exists.

\section{"Ever fresh the broad Creation, A divine improvisation From the heart of God proceeds, A single will, a million deeds."}

Our life is a becoming. Life is a becoming. Speaking reverentially, as one must, it seems to me that the Universe with all that it contains is but the outward semblance of one life that is self-developing, and that to speak of design in the ordinary sense is a crude and inadequate way of expressing the condition upon which that life subsists. Noth- 
ing is fortuitous; nor does it seem to be any more true to say that it is created, in the mechanical sense. Life is evolving: that is all that we observe, that is all that we know. The meanest thing that we see, the highest thing that we can conceive, are manifestations of that life, whose possibilities are beyond our conception.

"For I liave learned

To look on nature, not as in the hour

Of thoughtless youth ; but hearing oftentimes

The still, sad music of humanity,

Nor harsh nor grating, though of ample power

To chasten and subdue. And $\mathrm{X}$ have felt

A presence that disturbs me with a joy

Of elevated thoughts; a sense sublime

Of something far more deeply interfused,

Whose dwelling is the light of setting suns,

And the round ocean and the living air,

And the blue sky, and in the mind of man :

A motion and a spirit, that impels

All thinking things, all objects of all thought, And rolls through all things."

With the birth of consciousness we feel life; with the development of mind we are able to recognize it; with the growth of mind, to realize that we are of it; with the refining and exaltation of mind, we can deliberately fall into line and assume our share of the labor which carries that life, of which we are part, ever forward to higher issues.

Is it possible to contemplate any finer or holier relation, any higher destiny than thus exists? 


\section{ABSTRACT OF THE DISCUSSION.}

\section{I)R. MARTIN L. HolbRook :-}

In my judgment both animal and vegetable life have evolved from forms originally possessing some of the characteristics of both kingdoms. Possibly these forms are now represented by well known micro-organisms. Though scientists, after many years of doubt, now class them as belonging to the lower forms of vegetable life, some of them are as much animal as vegetable. They have no chlorophyll, they do not take carbon from the carbonic acid of the atmosphere, as plants do, but from other organic compounds, as ammonia, sugar, etc. They also require oxygen, which, like animals, they draw from the air. The cell-structure of the albuminous compounds of both plants and animals is almost identical. Some of the epithelia of animal and vegetable organisms are so much alike that $I$ have known very good microscopists to mistake those from leaves found in Croton water for those from the human skin and mouth.

Plants have many qualities in common with animals. The dandelion is as aggressive and capable of self-protection as a human being. It seems to have a sort of intelligence. When it sprouts in poor soil its leaves form a mat extending some distance from the stem, keeping other plants away. In rich soil, among other grasses, it uses its leaves, which are notched as if by design, as an ape uses its hands, to climb up to the sunshine. Other facts showing similarity of nature, make it probable that plants have evolved by the same law as animals.

\section{Professor Williay B. Ridenour :-}

The study of botany is, throughout, illustrative of the principles of evolution. The gardener in a few years, by his skill, does what it takes nature centuries to accomplish; but he must do his work over and over again, as there is a strong tendency to deteriorate and revert to the original type. Nature's work, gradually adapting the organism to environing conditions, is more permanent.

\section{Mr. James A. Skilton:-}

Human progress is largely dependent on botanical conditions, and the character of a vegetation largely determines the character 
of the men of a given locality. The thistle which Adam eursed, according to tradition, is a product of de-volution, botanists assure us. By studying the laws and conditions of evolution in its total range, we have the materials for a science of prophecy, which may ultimately enable man to lay hold on the future, and greatly liasten the progress of eivilization.

Di. Robeit G. Eccles:-

All science in one sense is pre-vision or prophecy. The botanical divisions of plants are arbitrary, and do not indicate an absolute separation of species. The difference between those most alike in different genera is no greater than between some which are classified as belonging to the same genera, but of clistant orders. The plants of China and the northern part of America are so much alike as to indicate a common origin in the present Arctic region when the two continents were united, and a warmer climate existed in the polar regions.

\section{Dr. Lewis G. JANES:-}

A notable distinction between the organic and inorganic kingdoms is observed in their different methods of growth - the latter by accretion, or simple addition to bulk; the former by intussusception, or displacement and renewal of particles throughout the whole tissue. On the theory of spontaneous generation, science has not yet explained how one method was exchanged for the other, in the passage from inorganic to organic structure. 


\section{EVOLUTION OF ANIMAL LIFE}

BY

ROSSITER W. RAYMOND, PH.D. 


\section{COLLATERAL READINGS SUGGESTED}

\section{IN CONNECTION WITH ESSAY VI.}

Darwin's Origin of Species; Haeckel's Creation; Spencer's Biology; Huxley's Palceontology and the Doctrine of Evolution (in Critiques and Addresses), Lectures on Evolution, and On the Origin of Species; Lyell's Geology, and Lamarck and Darwin, and Various Theories as to Species; LeConte's Geology; Wallace's Contribution to the Theory of Natural Selection, Geographical Distribution of Plants and Animals, and Malay Archipelago; Chapman's Evolution of Life; St. George Mivart On the Genesis of Species; Powell's Our Heredity from God; Karl Semper's Animal Life as affected by the Natural Condition of Existence; Ransom Dexter's The Kingdoms of Nature. 


\section{EVOLUTION OF ANIMAL LIFE*}

Axy subject displayed systematically-as, for instance, in tabular form - may be examined in two ways. We may read the columns of the table vertically, or horizontally; and each method reverses the principle of classification upon which the other is based. Thus, in Mr. Herbert Spencer's famous sociological tables, if we take the sheet devoted to a given nation, and read the columns vertically, we obtain in each column a record of the progress of that nation in some one particular, such as music, literature, mechanic arts, government, social customs, etc.; while by reading across the columns horizontally, we obtain, for the period represented by the line we follow, the condition of the nation in all these particulars. Which way is the best, depends on what we wish to study. If England in the tenth century is our special subject, we read horizontally; if the history of music in England is our subject, we read vertically.

Now Evolution can be exhibited in a similar way. We may conceive the different departments of Cosmical, Inorganic, Vegetable, Animal, Human, Social and Spiritual Evolution as constituting the first vertical column, while in other columns, under the heads of Philosophical, Geological, Morphological, Embryological, Geographical, Historical and Experimental, we may give the proofs and facts of Evolution for each department. Which way should this table be read? Horizontally, if we are satisfied as to the truth and fully informed as to the nature of Evolution; vertically, if we wish to get the force of its evidences, and a comprehension of their nature.

In the plan of this course of lectures, the horizontal lines have been followed; and I am to speak to you to-night on the Evolution of Animal Life, avoiding, as far as possible, the proofs and illustrations furnished by the fossil remains, the life-history, the distribution and the variation of plants.

* Copyright, 1889, hy The New Ideal Publishing Co. 
This seems to me unfortunate; perhaps because it shuts me out from those wide generalizations which are so much easier for both speaker and hearer than the patient study of details. Some one has said that any smart young man, with pen, ink, and paper, can compose a scheme of cosmogony in two hours. Something like this was done by Poe, in his essay, "Eureka," stating a theory of the universe which, he said, must be true because it was so beautiful. The trouble with such arguments is, that we are not able to say what is beautiful until we have discovered what is true. Still, they have a wonderful charm for us. I think the very general acceptance of the philosophy of Evolution which has come about within the last twenty-five years has been largely due to the perception of its beauty, as a harmonious and comprehensive arrangement of all phenomena. And if I were only permitted to traverse the table to-night vertically, instead of horizontally, I should feel much more certain of entertaining, if not instructing you. In fact, there is no telling how brilliant would be the address I am not going to make! Let me smother my regrets and awaken yours, as I come humbly down to the horizontal method, and confine myself to my theme: the evolution of animal life.

Under this title, I do not understand that the origin of animal life by evolution from plant-life, or the origin of the organic by evolution from the inorganic, is meant, although a strict construction might require that meaning. In such a sense, little could be said except in demonstration of ignorance. Until a sharp dividing line between plants and animals can be established, it is not likely that we can philosophize to much purpose as to whether and how that line was crossed by evolution. And as to the doctrine of abiogenesis, or the spontaneous generation of organic life, its truth has neither been proved by trustworthy experiments nor disproved by the failure of such experiments. Nor does that failure discredit in any degree the philosophy of evolution. Indeed, Professor LeConte, one of the latest and most lucid of writers on this subject, deduces from his second fundamental law of evolution the corollary, that if spontaneous generation ever took place, it necessarily cannot be possible now. To this extent, I do not follow him. It is sufficient here, however, to point out that the origin 
of animal life has littie to do with our present subject, which is the operation of evolution in the animal kingdom, or, in other words, the evolution of animal forms. This involves more particularly the consideration of the Darwinian hypothesis; but, at the risk of seeming superfluously simple and trite, I venture a prefatory explanation of the distinction between Evolution and Darwinism.

I. What is the Evolution of Animal Forms?

LeConte happily describes Evolution as "continuous, progressive change, according to certain laws and by means of resident forces." As applied to animals, it means that all existing forms, and all of which we have evidence from the past, have been produced by descent with modifications from pre-existing forms.

The "laws" of this continuous change are merely formulas to express in general terms its observed facts. As given by LeConte, they are:

1. The law of differentiation, namely, the general fact of a constantly increasing range of difference among existing forms.

2 . The law of the progress of the whole, namely, the general fact that, although there is retrogression and reversion in parts, the whole system steadily advances to higher functions and wider variety, like a tree, the upward and spreading growth of which as a whole is not measured by the irregular form or deficient development or retrogressive metamorphosis or death of any subordinate branch or leaf.

3. The law of cyclical movement, namely, the wave-like, successive domination of types, which rise, reach a maximum and decline.

These laws are not proofs of Evolution. Indeed, they were chiefly established in their completeness by Agassiz, the great opponent of that theory, who read in them merely the expression of the order in which successive forms have been introduced.

It is the third clause of LeConte's definition, "by means of resident forces," that characterizes the theory of Evolution. These resident forces are internal (determining heredity, variability, functional adaptability, etc.) or external (the forces exercised by climate, supply of food, enemies and rivals, etc.) The latter are summed up in the phrase," the environment." Evidently the forces which are internal to 
any one individual are part of the enviromment to other inclividuals, even of the same species, with which it may come into competition.

Now the theory of Evolution is that in some way, by the combination of such interior and exterior forces, successive animal forms have been produced. How this probably took place, it not necessary to show, in order to establish Evolution as the most rational explanation of the facts. It is quite true that a plausible suggestion of the mode of Evolution would greatly assist in recommending the theory; but it is conceivable that an argument may exist - and, in fact, such an argument does exist - based on undisputed observations, and establishing the theory of some sort of Evolution. In other words, a man might with perfect consistency believe that animal forms had originated by descent, and yet reject the Darwinian hypothesis as a complete or half-complete statement of the mode. He might think that Darwin's formula left out more important factors than any of those it contained.

This is, indeed, the attitude, to a greater or less extent, of the great body of scientific men at the present day. The Darwinian agents of natural selection and sexual selection are very generally held to have less controlling importance than he (or rather, his ardent disciples - for Darwin was not an extreme Darwinist) gave to them, in their first enthusiasm. Mr. Spencer, and many eminent naturalists (especially in America) lay greater weight upon laws and processes, some of which are known, and others only surmised, by which, more definitely than by natural selection as he conceived it, specific stability has been determined.

And this is the secret of the occasional announcements which we hear (mostly, I am sorry to say, from the pulpit), that Evolution has had its day, and is already on the wane; that the best scientific authorities are rejecting it, and so on. How far this is true of Darwinism, we shall presently see. Of Evolution, in its wider sense, it is not true at all. The victory of that philosophy is complete; and the sooner theology realizes it, the better for theology.

II. What is the Theory opposed to Evolution, is The Animal Kingdom?

The opposite theory is, that species are substantially permanent, originating, each in its present form, in a first pair or pairs ; spreading by migration ; forming, perhaps, varieties 
or races but never truly new species; and, when extinguished, being replaced by other species of similar independent origin.

It is important to note what is really involved in the issue thus stated.

1. The theory of independent specific origins does not necessarily imply an appeal to direct, miraculous, special acts of creation, outside of natural law. Its most zealous advocates have always asserted the creative power in ordinary birth. The catechism asks, "Who made you?" not "Who made Adam?" The answer is "God"; not "My father and mother." And the old theory of specific origin requires no greater miracle than birth. It involves merely, first, the denial that species have originated from one another; and secondly, the declaration of complete ignorance as to the manner in which they did originate.

On the other hand, Evolution does not exclude the Divine agency, but simply presents a process in which that power may act as truly as in the process of birth. If the evolutionist does not believe that God made him and you and me, he will probably not believe that God made anything. But there is nothing in Evolution to force him to that conclusion. In short, the whole controversy can be carried on perfectly well by atheists, or by theists, on both sides; and the odium anti-theologicum, as well as the odium theologicum, is quite out of place in it.

2. Neither theory involves the denial of design in the universe. Evolution, indeed, indicates a far wider, more harmonious and more comprehensive design, to one who is willing to see any; but pantheist, agnostic or atheist may hold either view of the origin of species. There were atheists plenty, before Spencer and Darwin were heard of.

3. Neither theory affects the authority of Scripture. Even the most extreme believer in the infallibility of the letter of Scripture finds no description there of the manner in which God "created the heavens and the earth," or the succession of living things, or man "out of the dust of the earth." He finds no statement of a specific act any more precise than that of a hundred natural phenomena, the secondary causes of which are now known. "He toucheth the mountains, and they smoke!" Does that contradict the theory of volcanoes?

Moreover, in the interpretation of Scripture (still on the 
basis of the most extreme view as to its infallible authority), the very first step is the inquiry, what the particular Scripture interpreted is : Poetry, Law, Dranr, Prophecy, Parable, Fiction, P'roverb, Quotation, Philosophy, Doctrine, Prayer, History, Legend, Myth, or Allegory. 'They are all there; and though some of them are easily recognized, the nature of others is not so clear, especially when they are mingled together, as is often the case. Hengstenberg, the great orthodox interpreter of Messianic texts, declares, in his "Christology of the old Testament," that some of these prophecies were intended to have a literal, others only a spiritual, fulfillment; and that the way to tell them apart is very simple. Those which have had a literal fulfillment were intended to have it; and those which have failed in that respect were spiritual. This leaves a third class, for the fulfillment of which we must wait, before putting them under one or the other head!

I shall not stop to criticize this method of handling Scripture, more than to point out how little it leaves of real authority, even in an infallible text. Applied to the first chapter of Genesis, it has given us, not an inspired and accurate scientific guide, revealed through Moses, but Hugh Miller's and Professor Hitchcock's, and Professor Guyot's, and Professor Tayler Lewis's, and Professor John Phin's, and a hundred other explanations of Genesis, modified to suit the successive advances of geology. I complained once to Mr. Beecher that the clergy would not stand still in their interpretations of Moses. Said I, "If you have got an anthorized revelation, why don't you give it to us?" "My boy," he replied, in a mysterious whisper, "It is all your fault! If you geologists will once tell us, finally and absolutely, what science proves, we will give you the exact meaning of Moses on the following Sunday!"

Now, this attempt to preserve the nominal infallibility of Scripture, while substituting for it in reality the authority of variable interpretations - as the fiction of the divine right of a powerless Emperor has often been maintained by Princes who did what they liked in spite of him - may be a great mistake. I think it is. But what I want to say at present is, that physical science is not its chief antagonist. The notions of the inspiration, authority and literal infallibility of the Bible are not attacked, as has been popularly supposed, by astronomy, geology, biology and Evolution, 
but by archæology, philology and historical and literary criticism. It is the analysis of Scripture itself, its structure, its origins, and its meaning, which has undermined and shaken the post-Reformation doctrine, put forward with ludicrous audacity as ancient and orthodox; and it is this study of the Bible itself which will restore to us the truly scriptural and truly Christian doctrine of inspiration. With that contest, the physical and biological sciences have little or nothing to do.

4. Neither theory necessarily either involves or excludes the origin of species from single pairs. Darwinism, as first propounded, may seem to require a numerous ancestry; yet even this condition ceases to be necessary under the latest form of that hypothesis. But, however that may be, Evolution makes no such requirement. Nor, on the other hand, cloes the independent origin of species require a single pair; since it is equally conceivable that the natural or supernatural cause which could produce one pair could produce any number at the same time.

III. The Ixquiry.

Having thus cleared the ground of misleading and confusing side-issues, we may freely inquire whether species are permanent or plastic; whether they originated independently, or by descent with modifications. The argument cannot be a mathematical demonstration. It remains to the end a weighing of probabilities. And you will doubtless be relieved to hear that it is not the purpose of the remainder of this lecture to state it in detail. You will pardon me for saying that I am no great believer in the usefulness of lectures for such a purpose. They may stimulate, suggest and assist; but they cannot replace the study of books which alone will enable you to appreciate the considerations urged on either side. Fortunately, there are books enough, both learned and popular.

What I purpose now, is simply to lay out before you the elements of the discussion, and to explain, briefly, and therefore incompletely, its general situation at the present day, particularly as regards the Darwinian hypothesis, as a mode of Evolution.

First of all, we start with a postulate, common to both sides, namely, that the universe is a system addressing itself to reason (whether it be, or be not, the product of a Divine reason). The sequence of cause and effect is uni- 
versal, and identical effects, or consequents, must be ascribed to identical causes, or antecedents. We are conscious of indefinite liability to mistake in the application of this principle; but our faith in it remains unaltered and fundamental. Hence, when we are able to say with high probability of any phenomenon that it is, together with all related phenomena, in all respects exactly as if it had been caused in a certain way, we conclude, subject to correction from larger knowledge, that it was so caused.

And while waiting and working for such larger knowledge, we proceed, and are right in proceeding, exactly as if our inference were correct. In scientific phrase, we make it our "working-hypothesis." Thus, when we find rocks disposed in layers exactly as if they had been deposited as sediments of sand or clay from water, we conclude that they were so deposited. When we find in them forms which resemble perfectly the remains of animals buried in such sediments, we conclude that the bodies of animals were so buried. The monkish fathers, who declared fossils to be but evidences of the Almighty power which was able to make such simulacra, to mock the human reason, were as false to religion as to science. God issues no counterfeit bills. The inscriptions He writes - if we can only make them out-are true. 'The question then is, what do the phenomena of animal life and its records in the earth's crust indicate as the probable cause of the present and past variety of species?

\section{Admitted Facts.}

It is a remarkable circumstance that there should be so little controversy as to the facts, however much opinions differ as to their significance and relative importance. The following list will suffice to recall the facts admitted by all parties.

1. The lapse of vast periods of time since the introduction of animal life on the earth.

$B$. Continuous change in geological, geographical, topographical, climatic and other conditions, constituting the enviromment.

C. 'The successive appearance of different species, in a certain general order, exhibiting the laws of differentiation, progress of the whole, and cyclical movement. 'The first law is shown in "prophetic types," or forms combining the characteristics of two groups, which are found to have ex- 
isted before the appearance of either group; the second, in the recognized advance of life on the whole, as for instance, in the series Mollusk, Fish, Reptile, Mammal, Man; the third, in the successive culmination of each of the groups of the series just named, in the Silurian, Devonian, Mesozoic, Tertiary and Quaternary, and Present geological ages respectively.

$D$. The inclusion of all past and present animal forms within a few great, persistent types of structure. (Protozoans, Radiates, Mollusks, Articulates and Vertebrates.) We think mostly of the Vertebrates, when we speak of animals. In the series just named as an illustration, all the members except the first are vertebrates. Yet of more than 500,000 species determined, the vertebrates number only 25,000 . It is a noteworthy fact that of the myriad other forms not one has ever been found that could not be recognized as belonging to one of the few great types mentioned.

$E$. The facts revealed by comparative anatomy concerning the adaptations to special uses, within each type, of the structural elements common to the type, or their retention without use - the facts of homology, morphology, rudimentary organs, etc.

$F$. The facts of embryology - particularly the wonderful passage of the embryo through successive stages of resemblance to features characteristic of species of earlier origin, in the order in which those species appeared in nature. This phenomenon is not every where discernible; but it has been proved in certain instances - notably with regard to the brain of the human embryo, which resembles successively that of a fish, a reptile, and a mammal, before assuming human shape and proportions. There are other facts of embryology, of which time will not permit the mention here.

$G$. The geographical distribution of species.

$H$. The fact that, within the life of a single individual, organs are affected in size and structure by change of functions, use or disuse, and, to some extent, directly by the environment.

I. The fact of heredity: that offspring always resemble their parents and ancestors, and that inherited peculiarities are likely to be intensified when both parents or many ancestors have possessed them.

$K$. The fact of variation: that offspring are never exactly like their parents, but combine individual character- 
istics with the features of ancestral resemblance. The facts, both of variation and of heredity, are known but imperfectly; and their laws have not been discovered.

$L$. 'The fact of multiplication, namely, that even the slowest-breeding species of plants or animals, if permitted to increase at its normal rate, would have crowded the globe long ago, as is shown not only by theoretical calculations, according to the rules for the summation of geometrical series, but also by well-known and recent instances, in which single species, imported into regions new to them, have spread with astonishing rapidity, sometimes to the extinction of native species. The Canada thistle and the Norway rat in this country, the wild horses of Mexico, the English grasses in Australia and the rabbits in Tasmania, are familiar and striking examples.

II. The fact of population, namely, that this rapid normal increase does not, in general, take place, but, on the contrary, the numbers of each species, in the absence of decisive changes introduced by nature or man, remain comparatively stationary. Occasional decimation, as, for instance, by exceptional weather or famine, is quickly made good by the increase of the species again to its normal proportion. The disturbance of this proportion by man is often followed by the rapid increase of some other species, previously held in check by the one he has destroyed or driven away.

N. The fact of the effective life-period, as concerned in this inquiry, namely, that animals have fultilled the function of life when they have been born, grown to maturity, produced and (in some cases) nurtured their normal number of offspring. Until these functions are completed, death is premature; afterwards, it is natural, and, so far as this inquiry is concerned, relatively insignificant. $N$, it will be seen, includes the sphere of "sexual selection."

$O$. The fact of competition and struggle among individuals and species and against the forces of nature, for food, strength, shelter, victory over enemies or escape from them, and for the production of offspring, etc., in short, a struggle for effective life, as defined under $N$.

$P$. The fact of the "premature" death of the majority (generally the vast majority) of each generation.

Q. The production, by selection and close breeding, of 
artificial varieties of plants and animals, showing peculiarities as marked as those of species.

$R$. The intersterility of species and the interfertility of varieties, together with the phenomena of r zversion to the ancestral form.

V. Deductions from the Facts.

We may for convenience recapitulate the foregoing facts under brief titles, thus:

$A$. Time; $B$. Change of Environment; $C$. Succession of Forms; $D$. Types; E. Homologies ; $F$. Embryonic Stages; $G$. Geographical Distribution; $I I$. Direct Organic Modifications ; $I$. Heredity ; $K$. Variation; $L$. Multiplication; $M I$. Population; $N$. Effective Life; $O$. Competition; $P$. Premature Death; $Q$. Artificial Selection; $R$. Intersterility of Species.

And for further convenience, we may refer to these facts by the letters which designate them, by which device we shall be enabled to put in small space our summary statement of the discussion.

$A$ to $G$ inclusive are so much better explained on the theory of some derivation of species by descent, than in any other way, that Evolution, to this extent, may be said to have been fairly established. In the present state of our knowledge, we are obliged to say that the facts are as if specific derivation had taken place, and we cannot believe that either natural law or a rational Creator is mocking us with delusive appearances. Nor do the advocates of independent specific origins suggest any theory whatever to explain how these indications of relationship have been produced.

$G$, it must be confessed, lends itself to either view, so far as the distribution of species is the result of migration. But in many respects, it is more in harmony with Evolution; and the one point which has been suggested as a difficulty; namely, the absence of any shading-off or blending of specific peculiarities on the borders of the geographical habitat, is founded in a misconception. "Missing links" are to be sought in the past, not in the present; at the junction of branches, not in the air between their extremities.

$H$ is the "Lamarckian" factor, and, together with $I$, was principally relied upon in the theories of descent suggested by Lamarck, the elder Darwin, Robert Chambers (author of 
"The Vestiges of Creation") and others. But the notion that changes produced in the individual could be accumulated by simple inheritance into permanent specific structural peculiarities, was rejected as inadequate. So indeed it was, standing alone; but as factors in derivation, according to our present conception of that process, the Lamarckian or interior resident forces are gaining wider recognition.

Darwin's theory includes $H$, but is based mainly on $I$ to $P$ inclusive, with $A$ and $B$. We might symbolize it as follows, taking care not to attach a mathematical meaning to our equations :

(1) $\mathrm{MN}=\mathrm{L}$

(2) $\mathrm{LO}=\mathrm{P}$

(3) $\mathrm{L}-\mathrm{P}=\mathrm{M}=\frac{\mathrm{L}}{\mathrm{KO}}$

(4) $\mathrm{MI}=\frac{\mathrm{IL}}{\mathrm{KO}}$

(5) $\left\{\frac{\mathrm{IL}}{\mathrm{KO}}\right\} \mathrm{AB}=\mathrm{AQ}=\mathrm{R}$.

Or in words :

1. The number of individuals in a given generation of a species, who complete the functions of life, produces by the law of multiplication the number which will compete for similarly complete life in the next generation.

2. In this multiplied offspring, competition causes the premature death of the majority.

3. The remainder constitutes the effective population for that generation, and since it will tend to consist of those individuals best fitted for $N$, it will be the result of individual differences according to $K$, and will constitute a fraction of $L$, determined by $K$ and $O . \frac{L}{K O}$ is therefore a symbol for "the survival of the fittest."

4. The population of the fittest survivors, thus preserved, will tend through $I$ to intensify its advantageous peculiarites, in each succeeding generation.

5. This process, continued long enough $(A)$ under the changes of environment $(B)$, will produce results like those of artificial selection, and moreover, will bring about, as artificial selection might do if continued long enough, true physiological species, characterized by intersterility. 
The Lamarckian equation, on the other hand, might be written $A B H I=R$.

VI. The Failure of Darwinisu.

Now the Darwinian argument, as shown in equations 1 , 2 and 3 , is unquestionably sound. There is a competition for life and there must be a survival of the fittest. It is in equation 4 , with the introduction of $I$, that the trouble begins. For $R$ belongs in this equation too, and $R$ cannot be had without $A$. It is therefore extremely doubtful whether the theory provides for $R$.

In other words, according to the Darwinian formula, the results of natural selection are achieved "in the long run"; the amount of the variation selected by nature through competition is, for any single generation, according to this theory, extremely small; and the analogy of artificial breeding which it invokes calls for the production first of interfertile varieties, which shall harden in time into intersterile species. But what is to prevent these varieties from being swamped in the very first generation by crossbreeding with the parent stem? Again, if the struggle for life results in the perpetuation of useful variations only, why should not specific characters not belonging to this class go on varying? As a matter of fact, it is the generic rather than the specific peculiarities which are most clearly advantageous.

Mr. Darwin foresaw these difficulties, as what did not that patient and candid investigator foresee? They center in the laws of heredity, variation and fertility or sterility, all of which are as yet relatively unknown. In his acute discussion of them, he followed still the analogy which had led him from the first, and assumed that the species created by nature began with interfertile varieties. He argued indeed, in his "Origin of Species," that the intersterility of species is not produced by natural selection, but is due to unknown peculiarities of the reproductive system.

VII. Darwinisur as Perfected by Romanes.

It was left for Dr. Romanes of London, to propound in 1886 what is, as Professor LeConte justly observes, perhaps the most important, if not the only important, addition which the Darwinian theory has received, namely, the hypothesis that natural selection operates upon those varieties only which are not interfertile with other varieties ; in other words, that such peculiarities of relative intersterility are the factors 
which determine, among the "fittest survivors," which shall breed true, and so transmit their fitness. This hypothesis is based on a fact which may be added to our accepted catalogue (though it is included under $K$ ), namely, the frequent intersterility of individuals of the same species, and the corresponding interfertility of the same individuals otherwise grouped. The causes are both physiological and, among the higher animals, psychological. The former are almost wholly unknown to us; the latter are evinced in repugnance and avoidance between the individuals. Whatever the causes, the phenomenon is undeniable.

Now the reproductive system of animals is most sensitive of all to causes of change; and it is not improbable that in every generation of a wild species there exists this partial intersterility. Let us suppose, then, that out of a million individuals competing for life in an enviromment which will support 400,000 , say 100,000 of the survivors possess a small advantageous peculiarity, while the other 300,000 , though at some disadvantage, manage to live to the next generation. That is, there are 100,000 "fit" survivors, and 300,000 lucky ones. Assume that, out of this 100,000, there happen to be 1000 individuals, who can or will pair with one another only. The rest breed freely with the unprotected but fortunate 300,000 , and the next generation gives us 1,000,000 individuals again, of which say 2500 are the offspring of the close-breeding 1000. Perhaps only half of these retain both the protective peculiarity and the protective sterility or aversion. But it will easily be seen that while natural cross-breeding obliterates in each generation the majority of the variations, there is a protected close-breeding going on, which, if it only produces, at last, a single pair with well-marked and permanent peculiarities, and sterile toward the rest, has given the condition for a new species.

And this process shortens immensely the time required. We know by experience how quickly a new species of superior fitness will exterminate or lrive out all others.

Migration is thus not necessary as an element of preservation to the fittest. It is the inferior which must run away.

Again, this theory accounts for the preservation of protective specific characters. It permits even the formation of new specific characters not protective. 
The analogy of artificial breeding is deceptive in this: that we select plants and animals for their desired peculiarities, and prevent cross-breeding. We do not select out of the aggregate of forms we desire to perpetuate those which, besides having that peculiarity, are fertile with one another, but sterile towards the rest. Hence our varieties are subject always to cross-breeding and reversion. In other words, we do not get specific sterility, because we do not breed for it. But Nature starts with that, and performs by her selection the close-breeding which we secure by artificial devices.

Finally, this theory, which makes relative sterility with special interfertility one of the protective modifications upon which natural selection proceeds, is after all only a restatement of the Darwinian formula itself. For the survivors in each generation, retaining in most effective degree the advantageous peculiarities which distinguish them, are most likely to be the offspring of the protected parents on both sides. Cross-breeding will be punished by reversion and loss of advantageous peculiarities.

This may be expressed in our fanciful symbolism by substituting for Darwinian equations 4 and 5 , the following:

$$
\begin{aligned}
& \left\{\frac{M}{K}\right\}^{\prime} I=\frac{I L}{K^{2} O} \\
& \left\{\frac{I L}{K^{2} O}\right\}^{n} A B=A\left\{\frac{Q}{R}\right\}=R
\end{aligned}
$$

That is to say, natural selection acts twice on each generation, selecting from the fittest to survive $(M I)$ the fittest to breed; and this process, repeated through numerous (n) generations produces physiologically permanent species, as artificial selection $(Q)$ would do, if it were directed towards intersterility $(R)$ as one of its objects, and continued through a sufficient period $(A)$.

What Mr. Darwin apparently overlooked was the probable decrease in numbers of the pure-blooded variety, accompanied by a complete isolation from related forms, until the new species takes its start, perhaps from a single pair, which, in its swift multiplication thereafter, sweeps away all the feeble varieties of the old stock which may have accompanied its history. 
As I have said, the laws of heredity and variation are little known. It is in this direction, doubtless, that further light may be expected. But there is already light enough to permit us to see that the production of specific animal forms by derivation, and not by independent origin, is the only rational theory we can entertain; that the Darwinian hypothesis, as now reinforced and complemented, is more satisfactory than ever as an explanation of the mode of such derivation; and that, thus explained, the succession of life upon the globe falls into its place as a harmonious element in what I, for one, conceive to be the vast, complex, yet orderly and rational expression of an immanent, self-revealing God. 


\section{ABSTRACT OF THE DISCUSSION.}

\section{Dr. Robert G. Eccles :-}

Professor Raymond's method of presenting the subject strikes me as the most incisive and best of any I have ever read or listened to. It displays marked originality of arrangement and a keen, clear appreciation of the subject in every detail. The method pursued in showing the evidence from embryology is particularly lucid, and no doubt perfectly understood by all present even though entirely new to some.

I am pleased to note that Dr. Raymond is among the progressive evolutionists who have accepted Professor E. D. Cope's "NeoLamarckism." No purely mechanical theory can ever explain the present arrangement of things; and the evidence is multiplying that shows mind to be an active participant in the moulding process in the development of animal forms. Their desires and feelings direct their actions, and these in turn alter their shapes.

I think that the speaker of the evening made a little too much of the argument from the infertility of crossed species. Darwin himself has shown that so far was this from being an insuperable objection, that, instead, it is just what we might expect in an evolutionary system. The only reason why we liave not artificially produced infertile crosses, is the shortness of the time during which we have been experimenting. In the plant world, where generation is more rapid, it has been shown that there is a clegree of kinship at which fertility is at its maximum, and that from this it shades off in both directions toward greater and greater infertility. The most remote will not blend at all. Those nearer will blend, but produce infertile progeny. Approach nearer still, and the progeny will run out in a generation or two. At the maximum point no known limit is found. Get nearer than this, and fertility again diminishes; we find some highly differentiated species infertile to their own pollen. Experiments have shown that artificial selection travels along this line, only it has not had time to reach the point of rernote total infertility, or even that of infertility after a generation. Had the pouter pigeon been selected with reference to generation as it has in reference to shape, it is not unlikely that we would have had in it a true new species. It is manifestly impossible in an hour's talk to refer to every phase 
of a subject so vast as that of the evolution of animal life. Many telling arguments in its favor must be neglected.

The relations of islancl-life to the subject are most interesting, but did not happen to come under the speaker's consideration. Where islands are remote from a mainland, the type of life found thereon is usually unlike in the two; and in proportion to remoteness, so is difference. If streams and winds flow and blow from the nearest mainland, the type of life in each is nearer alike than is that of the island to that of any remote mainland. Under such circumstances fossil life heightens the affiliation, just as it should if evolution is true. When ocean-currents and trade-winds come from a remote mainland toward the island, then the life is very much unlike that of the near mainland, but markedly like that of the remoter place. But even here there is not identity. New varieties and new species exist in the two. The kinship is clearly marked, but time has effaced identity by the efforts of natural selection. Adaptation to new conditions has necessitated change.

The story of geographical palæontology is necessarily much mixed because of innumerable migrations from country to country; but its general outlines are highly confirmatory of evolution. Excluding the contrast of places in the North Temperate Zone because of undoubted pre-glacial migrations even across the arctic region, and a number of telling facts can be adduced. Conditions in the past isolated South America and Australia from such invasions, and what do we find there, accordingly? The fossil animals of the latest tertiary rocks of the North Temperate Zone are like the living animals of the same region, but unlike those of Australia and South America. The same is the case of the last two when contrasted with each other and with the former. South America, for instance, contains Sloths and Armadillos, and its rocks reveal the sloth-like Megatherium and the armadillo-like Glyptodon. Its past fauna does not resemble that of Australia nor Europe, but bears a striking resemblance to its own living forms.

The theologic bearing of evolution has frequently been referred to in the lectures of this course. That the cloctrine is not antitheistic can be most successfully maintained. It certainly leaves the God-idea free from the degrading implications of current every-day thought. For a carpenter to make a chair may show great human skill on his part; but his power would be infinitely short of that of a being who could make a chair make itself. Even so, a God that could make a world might be quite a skilful artizan; but such a conception as applied to Deity is degrading. How much more sublime is the thought of an Omnipotent Being who 
makes worlds make themselves! Such was evidently the thought of the apostle who said, "By the word of his power" were all things made."

\section{Professor P. H. VAN der Weyne:-}

I desire to present to the Association an autograph letter of Charles Darwin, never heretofore published, and of interest as bearing upon the subject of this lecture. It was written to my son, who was traveling in South America, and taking photographs of such noteworthy objects and animal remains as he thought worthy of preservation and subsequent study. Some of these photographs, at my suggestion, he sent to Mr. Darwin, receiving this letter in acknowledgment.

\section{Letter of Charles Darwix:-}

The letter of Mr. Darwin, which was read to the Association by the President, Dr. Janes, is as follows:

\section{Down, Bechinghair, Kent,}

September 29,1876 .

Dear Sir: I am much obliged for the photographs which you were so kind as to send me. I have sent them to Professor Flower (one of the most capable judges in England) of the Royal College of Surgeons, where my specimens from the Rio Plata were deposited. He admires the fine specimens of Toxodon, and says that all the others apparently belong to Mylodon. I am extremely glad that you and your friends intend collecting the fossil mammals. I will make two or three suggestions, though perhaps superfluous.

Judging from a distance, the Barrancas de Gregorio seem to me worth investigating; and it would be advisable to ascertain where these cliffs are contemporaneous with the Pampean formation. Secondly, as far as I know, the bones of the smaller mammals have not been collected, and these might be as valuable as those of the gigantic mammals: at M. Hermora, near Bahia Blanca, I found the remains of small species. ' Thirdly, it would be of paramount importance to find mammalian remains in the tertiary strata, such as those at Sta. Fè Bajada beneath and older than the Pampean formation. Near the mouth of the Uruguay I found such strata with great extinct oysters, and BEXEATH these a formation in character quite like the Pampean, and which therefore it is probable would contain mammalian remains.

Heartily wishing you success, I remain, dear sir, Yours faithfully, 



\section{THE DESCENT OF MAN}

BI

E. D. ÇOPE, Ph.D.,

AUTHOR OF "The ORIGIN OF THE FitTest," ETC. 


\section{COLLATERAL READINGS SUGGESTED}

IN CONNECTION WITH ESSAY VII.

Darwin's Descent of Man; Haeckel's Evolution of Man; Lyell's Antiquity of Man; Huxley's Man's Place in Nature (in Critiques and Addresses); Winchell's Pre-Adumites; Mivart's Man and Ipes; Joly's Man before Metals; Schmidt's Doctrine of Descent and Darwinism; Lubbock's Prehistoric Times; M. F. Force's Prehistoric Man; G. Dallas Lind's Man ; Nadaillac's Prehistoric Man in America; Nillson's Prehistoric Man in Slandinaria; Evans's Ancient Stone Implements in Great Britain, and Bronze Implements in Great Britain; Ribot's IIeredity; Lewes's Probierns of Life and Nind; Lindsay's Mind in the Lower Animals; Quatrefage's The Inuman Race; 'Tylor's Anthropology, Primitive Culture and Early IIistory of Mankind. 


\section{THE DESCENT OF MAN.*}

The modern doctrine of evolution is that theory of the origin of things as they now appear, which does not involve the introduction of energy from without. In this respect it is contrasted with the conception of creation. In biology it ranks man as one of the animals - the highest animal, if you please, but still an animal. The genealogy of man is therefore included with that of all species of animals. When the highest class, Mammalia, was developed, the possibility of man resided in it. Man is a vertebrate and a mammal. The curiosity developed by the perception of man's evident relation to other Mammalia has been answered by the discovery of the law of Evolution.

We have now pretty nearly a complete record of the descent of man. Low down in the genealogical line of man are certain of the marsupials, or pouch-bearing Mammalia, which bring forth their young in a very immature condition, and carry and nourish them in a pouch until they become able to walk. These survive now only in Australia, and in the opossum of the Americas, though formerly they prevailed over the whole world. Alove the Marsupialia are the Condylarthra, and from these branch out in one direction the groups of ungulate mammalia - the hoofed quadrupeds - including the Proboscidia, the Amblypoda, and the Diplarthra; which latter are in turn separated into the two sub-orders of Perissodactyla and Artiodactyla _- those which divide the hoof, and those, like the horse, which walk principally upon a single median hoof. In another direction are developed the Unguiculata or clawed quadrupeds, which are divided into the Bunotheria, the Carnivora, or meateaters, the Edentata, the Chiroptera and the Rodentia.

The human type is nearer to the hoofed type than to the clawed type, and branched off from the Condylarthra in a separate direction. Man is not developed from any existing order of anthropoid apes, though both belong to the sub-

* Copyright, 1889, by The New Ideal Publishing Co. 
order Anthropomorpha, of the order Quadrumana, to which all the ape family belong. Man's ancestors, however, branched off from the ancestral line as low down as the lemurs, once prevalent mammalia in North America, but now nearly confined to Madagascar, and which greatly resemble the Condylarthra. From the lemurs we trace the monkeys proper, and then the anthropoid apes, which come nearest to man of all the mammalia. Their vertebræ differ from those of the monkeys, and resemble human vertebrae. In the brain, also, they are nearer the type of man than of the monkey. They have the third convolution of the frontal lobes, which in man is the seat of the power of language, and which is wanting in the monkeys proper. But the difference between these apes and man is considerable, if we leave generalities and confine ourselves to details. They constitute in fact a separate family, the Simiidæ, though belonging to the same sub-order. In the sub-order Anthropomorpha there are but the two families — the anthropoid apes and man. The sole external anatomical difference is the great toe, which in the apes is opposed to the other toes, while in man it is parallel with them. In man the last true molars (wisdom teeth) are protruded after the appearance of the canines. In apes and monkeys the wisdom teeth appear before the canines are fully in place. But remains of a monkey have been discovered in Europe in which it is thought that the wisdom teeth are yet mprotruded, although the canines have reached their full development. This is the Dryopithecus fontani, an ape of about the size of man.

This, then, is the general view of the later stages of the genealogy of man. Those lines of descent in the Vertebrata carry within themselves the evidence that they have followed definite directions toward mechanical perfection, and attained definite results. We see this in the development of the limbs and of the other organs which tend to enable each group to live in the best possible manner. The Bunotheria, for example, have acquired claws, as a means of defense, and as an aid in climbing. The Rodentia have a different means of defense: they dig holes and thus escape from their pursuers. The bats have developed wings, and fly away. The lowest group, structurally, are the Edentata, whose general habit is to excavate for defense. The hoofed mammalia have developed powers of rapid locomotion, and can rum away from their enemies. In the quadrumanous 
group we find none of the special characteristics of the others - but it has triumphed in the struggle for existence, as this audience shows. Man has neither fleetness nor fossorial abilities. His ancestors took to the trees and found in an arboreal life both greater safety and abundance of food. They trusted to their wits instead of to fleetness or strength, and became the most inquisitive and intelligent of animals. Monkeys resemble man in these respects far more closely than other animals - even the intelligent dog or horse. All monkeys are exceedingly suspicious, and that indicates wisdom. When tamed, they have a remarkable power of readily discovering the state of mind of their masters. Anthropoid apes are also intelligent, but for various reasons their habits have not been studied as closely as those of monkeys. The defenceless condition and social habits of the Quadrumana have been, it is thought, the means of the development of their intelligence to a point which has made the human intellect possible.

As to the period of geological time in which man first appeared, there is much doubtful evidence. TVe have some evidence of his existence in Europe, where the ground has been more thoroughly investigated than elsewhere, before the glacial period. Flints, to all appearances artificially manufactured, have been discovered by the Abbe Bourgeois in the Middle Miocene of France, which may have been made by man. As an alternative Prof. Gaudry suggests that they may have been made by the Dryopithecus. In America palæolithic flints have been found in the glacial gravels of the Delaware valley, and, as I believe, in the upper Pliocene beds of the West and South West. William Taylor has found palæolithic implements in the same bed with Glyptodon and extinct species of horses in S. W. Texas. Ameghino has found human bones in the Upper Pliocene of Buenos Ayres. We find also the remains of primitive races in caves, as at Neanderthal and elsewhere, and they have been collected in sufficient numbers to show that some of them represent a race distinct from all existing races, - the lowest type of man we know, while others do not differ materially from modern types. Their anatomical characteristics are similar to those of the anthropomorphous apes as indicated by the thickness of the skull and lower jaw, the flatness of the tibia, etc. Man is the only quadrumanous animal possessing a chin. In the jaws of some of these 
cave-men the chin is almost wanting. A recent discovery of human remains of the pre-Indian period in Arizona, goes to show that primitive man was deficient in speech, as these skeletons retain the primitive distinction of other speechless mammalia; in having the hyoid bones separated. In man as we now know him, these bones are consolidated, for'ming a single bone.

The general theory of descent rests upon the study of species in detail. There can be no doubt in the mind of the student that the specific lines of definition are movable. Each species has stages of variability, when it is comparatively plastic, and susceptible of change, before it has developed an unyielding contour and form. Afterwards they develop into fixed types, and do not evolve into other species thereafter. 'This is the condition in which we find most of the animal forms at the present clay. Our cats, for example, are not variable, or are variable only within specific limits. Dogs, on the contrary, are very variable, and so are barn-yard fowls. Mankind is in a condition of plasticity or variability, and herein lies great promise of human progress in the future.

In attempting to account for the evolution of man, we have two theories, one of Lamarck and the other of Darwin. Lamarck devoted himself to explaining the origin of species, but not to the special problem of natural selection. The post-Darwinians, as they have been happily named by Romanes, have generally accepted Darwin's hypothesis as a complete explanation of evolution, but we are beginning to see that Lamarck's views cannot be set aside, and that it is of great importance in explaining the origin of variations. Without it, natural selection would have no opportunity for operation. The Darwinians say that animals and plants have a tendency to variation. But nothing happens accidentally - there can be no variation without a cause. Seeking out these causes of variation is the province of a certain school of biologists at the present time. To this study, the great nations of the world are all contributing. Chemistry has been called a French science. In embryology Germany stands at the head. Palæontology will doubtless constitute the contribution of America to this investigation. A rich field for this investigation exists in our Western States and territories, rivalled only by a similar field in the Argentine Republic. The fact that the earth cooled first at the poles, 
suggests that life began independently at each pole, and thence spread to other portions of the earth. Future investigations in the Argentine Republic are likely to throw much light on this theory, which cannot yet be said to be established as regards vertebrate animals.

Following the line of descent, we find that many lines of progress have maintained themselves, and that these lines are not accidental or arbitrary. Here and there, indeed, we find that some magnificent capabilities have been switched off the track; and for these progress has ceased. In other cases retrogression has taken place. A profound lesson may be drawn from the observation of this fact. We may be thankful that our ancestors got on the right track; and if we did come from a humble origin we can rejoice in what we have attained, and reflect upon what we may escape in the future.

The origin of variations can be traced to varied causes, and modifications are almost always explainable by careful study. The object of all things is to live; and to secure the means of living is the end which they aim to accomplish. The motion consequent upon this effort is the active, and the environment the passive factor in development. One of the first principles in progress is the capacity to move from place to place. Those animals which become sessile, or fixed to one spot, cease to progress, and tend rapidly to retrograde. The structural changes are induced by contact with environing conditions, and by motion. There is progressive evolution, and also retrogressive evolution; progress and degeneration. The competition of the struggle for existence compels excellence. The absence of it tends to inactivity and degeneracy. Groups have thus arisen, and then fallen. The result on the whole has been a constant advance since the beginnings of life on the earth; but the number of degenerate lines is nevertheless very great.

The Lamarckian view that structure results from use is undoubtedly correct. In this way certain mechanical causes have induced changes in the skeletons and teeth of vertebrate animals. These hard parts determine the character of the entire organism, the softer portions conforming to them and being modified in the directions which their changes indicate. The original impulse is in the activity of the animal. If all animals had been created alike they would at once hare begun to act differently, and modifications would 
have resulted accordingly. The Darwinian hypothesis excludes this important factor from the explanation of organic evolution. Natural selection proper does not account for the origin of intelligence, nor of design in structure; it ouly accounts for direction or tendency. Darwin's theory is true, nevertheless, as far as it goes. It accounts for the destruction of certain peculiarities, and for consequent structural and functional modifications, but it does not explain the origin of variations. Thus variation and natural selection combine to produce the results which we see in evolution.

We have obtained in North America partly complete genealogies of most of the modern types of Mammalia, but these do not include man, although his earlier ancestors, the lemurs, are abundantly represented. The lines of the deer, camel, peccary, tapir, hor'se, rhinoceros, cat, dog, beaver, squirrel, and various other mammalian types are very complete. From their fossil skeletons we can trace the changes which have successively appeared during geological time, and can investigate the causes which have produced them. After a careful survey of the field I am of the opinion that the origin of new types in the hard parts can be ascribed to the interaction of mechanical impacts and strains, with the antagonistic force of persistence of type, and that whenever the former overcomes the latter, a new structure appears, which is transmitted sooner or later to the succeeding generations. The evidence for this belief is abundant, and in some cases very simple; in other cases it is more complex. This theory explains the exact adaptation of animal mechanisms to their uses, and renders clear the continued progress in the direction of mechanical perfection which we find to have taken place throughout the ages of geological time. An opposing theory (that of Weismann) holds that acquired characters cannot be inherited, but does not attempt to explain the origin of variation. The evidence of palæontology indicates that acquired characters have been inherited, though exactly how this has been done requires explanation.

Sensation exists in the lowest forms of animal life, and it is accompanied by memory. Sensation and memory express the simplest acts of consciousness. A sensation experienced is likely to be recalled by association. Even the lowest animals show discrimination in the selection of foor, appropriating that which will nourish them and rejecting 
that which will not. So, the lowest forms of life show evidences of the possession of sensation and memory, and thus have the possibility of the development of mind. The result of the possession of sensation and memory is the capacity for forming a simple judgment. Insects such as the hymenoptera, like bees, wasps and also ants, show a marvellous development of intelligence, and no one doubts that they gained their intelligence in the same way as the higher animals. They have remained as they now are many geological ages. The ant and the bee do things with their own kind that man cannot do with his kind. They are practical stirpiculturists, and are more intelligent than many of the vertebrates. The ants have made as great a mark in the animal world as mankind has done. Thus they have called into existence numerous species, genera, and families of other animals that live on them. Among Vertebrata we have families of Batrachia (Cæciliidæ); of lizards (Amphisbænidæ); of snakes (Typhlopidæ); of birds (Formicariidæ); and of Mammalia (Myrmecophagidæ and Orycteropodidæ), six in all, composed of numerous genera and species, which live exclusively, or nearly so, on ants. Then ants maintain and propagate numerous parasitic species, mostly of insects. In Europe alone one hundred such species are known. Yet ants do not display the capacity for prompt adaptation to new circumstances so natural to man. Their action is now largely automatic, or fixed in a routine. Man has a great advantage over the rest of the animal kingdom in possessing a greater power of so-called voluntary choice in determining what he will do. This really means a higher intelligence.

Sensation, even in its lowest form, is something more than the operation of a merely mechanical energy. It is not analogous, as some have affirmed, to chemical reaction. The tendency of energy in the inorganic world is to dissipate. Sensation is profitable to its possessors in enabling them to resist this tendency. The dead products of conscious action are profitable-as witness the stored-up products of the chalk-cliffs and coal-beds so useful to man. In the combustion of coal we are liberating energy which was stored up by vital processes. The action of life has been to build, and not to destroy.

Sensation is probably a quality of all life, even of vegetable life in its first beginnings. All life-processes which are 
now automatic and mechanical were originated in sensation. Without sensation the animal kingdom could scarcely have existed except perhaps in its lowest forms. The perception of temperature is necessary to prevent destruction by freezing or burning. The senses of hunger and of propagation it is easy to perceive are necessary to the existence and persistence of animals as they are now organized. Sensation is also necessary to education. It is not the method of nature to produce intelligence out of unconscious bodies, but the reverse is the process; viz., that habits of animals, both conscious and unconscious, are the product of education during conscious states.

When we enter the realm of consciousmess we are in a universe which is in some respects not subject to the scales and the measure of the materialist. No doubt every act of consciousness requires for its performance the expenditure of energy, but there are some of the functions of mind which are not correlated with the amount of energy expended in producing them, so far as relates to their mental quality. of all mental acts this is especially true of the formation of a judgment as the result of a consideration of inducements, or reasons, or the mutual pressure of motives, No matter whether the judgment be free or not, the consideration of, the estimation of, and surrender to, reasons, is a process outside the pale of the scales of the physicist or physiologist. This is the most important fact known to man. Its shows that although his mind is bound to its material basis, it controls that basis, within limits, by purely mental processes, which are per se entirely free from the trammels of matter, although they may not be free from the laws of mental action.

Every time an animal performs a designed act for the first time, he makes a judgment. In other words every time an animal does anything for a reason, or as a choice between alternatives, he performs an act of judgment, until he has learned to do it so readily that the act has become automatic, or has become, in other words, instinctive. Thus every time such an act is performed there takes place an interference with the uniformity of action of the law of the conservation of energy; because a not weighable or measurable direction of energy takes place, i. e. in the movement of an animal's body.

The progress of organic evolution has finally result- 
ed in the development of a race capable of ethical action, and with hopes and longings after the ideal and the supreme. This points to a yet higher development and a superior race. The pointers are all in one direction in regard to the future of life and its functions. I cannot believe, either, that life is limited to this globe. The scientific cosmogony of the present day forbids us to regard the earth as the center of the universe, either in a physical or a moral sense. It is not impossible that we may yet know something of life on other planets. Even if there is no truth in Sir William Thomson's theory that the germs of life were originally brought to this earth by meteors, these have already shown us, in their occasional loads of carbon, something in confirmation of the existence of life in other worlds than ours.

The source of all the progressive mental evolution of man is sensation and experience. The pressure of human society upon each individual is the origin of ethical intelligence, of the knowledge of the rights of others; while the social life and the family relation have developed the benevolent sentiments and the affections. The combination of the knowledge of right and wrong with the benevolent sentiments, constitutes the mainspring for ethical action, inspiring the doing of right and justice. The history of human evolution is therefore the history of the development of the human mind. And the human mind is but a small fragment of the universal mind. The development has been along fixed lines. No new material has been created. That which we behold in Nature's final product was involved in Nature from the beginning.

From the point of view of the biologist, as to the relation of mind to matter, we observe that mind everywhere manifests itself in correlation with material conditions, and we must conclude that mind is a property of the substance which exhibits it. On its ethical side, we observe that the ordinary way in which man has learned to do the right has been a destructive or violent way. The struggle for existence is a method which involves suffering for the individual, but its final results are beneficent. But thought and prudence will keep man ahead of the destructive forces. The result of human experience in various lines has been the accumulation of a bocly of pure ethics, which when rightly understood will be interpreted as an 
invitation to keep ahead of the destroying Angel. The method of evolution and the conception of a beneficent tendency in the miverse are not therefore necessarily contradictory.

My friend, Major Powell, has recently affirmed in this city that man is exempt from the operation of the law of natural selection - that he has placed himself outside of the struggle for existence which prevails throughout the lower range of biological evolution. I do not see by what line of argument he can substantiate this view. The struggle still prevails in the competition which affects all our social and business interests, and it is likely to become greater rather than less as time goes on. Competition will increase as the population increases. No expedients yet devised by man will wholly prevail to prevent this. Tariffs will not help us - they will only postpone the final reckoning. The severity of the struggle, however, will only occur when the land is crowded everywhere - a time which is yet very far off. 'The most useful form of charity is the distribution of population from the overcrowded center's to the uncultivated lands of the interior. In this way, and by respect for the moral code which has been revealed to us by human experience, we may hasten the steps of progress, and long postpone the severity of the struggle which must otherwise constantly augment with the intensity of competitive effort. It is true, as has been asserted, that man relieves himself from the pressure of natural forces by the discovery and manufacture of mechanical contrivances. But this only constitutes a new element in the struggle for existence, which favors the discoverer, maker, and user, of such appliances, and constitutes them the fittest to survive, as far as it goes. It is also true that the discovery and use of the steam-engine has angmented the power of human labor, it is said, seventeen-fold; but this power, it must be remembered, is not equally distributed, but gives some men an advantage over others. And since men are not made "equal," even if they are "free," the gifts of power never" can be equally distributed, and so long as that is the case, natural selection must operate. 


\section{ABSTRACT OF THE DISCUSSION.}

\section{Dr. T. Musson CoAn:-}

It would be hard to add anything to the statements we have heard, so full of original thought, from Professor Cope. We could not desire anything more. And yet I have come across something of which I would like to speak in reference to natural selection. On a Southern plantation it appears that a cottongrower, a $\mathrm{Mr}$. Alexander, I believe, found a cotton-plant which had a peculiar leaf: instead of being in four lobes it had five separate portions, like fingers of the hand, thus permitting freer access to the sunlight and producing a finer cotton-boll, and, more than that, furnishing no shade for caterpillars. This gentleman was an evolutionist, and reasoned that this plant would be better than the common variety; he raised seed and cultivated it, and he found that it reproduced the same peculiar leaves, and he has continued to cultivate it with very satisfactory results. Here is a case where natural selection is combined with artificial selection, and together these agencies will probably speedily introduce a great improvement in cotton culture, driving out the old plant. Professor Cope will, I think, agree with me that nature unassisted would have done the same thing, only it would have taken a much longer time.

The question which comes to the front in this discussion is, How far does the principle of natural selection account for the ethical phase of human evolution? I think that the force which made that variation in the leaf of the cotton-plant is a benevolent force, working in all of us, morally and intellectually. The same force of environment which operates as natural selection in the vegetable world, operates also in man. This force is somewhat akin to fatalism - or, rather, necessity. Organization and circumstances impel us to action, and action modifies our character. What we start with in life, - our inherited nature,--is inevitable, but not the rest. Our actions are the result of our character and volition, quite as much as of environing circumstances. If we believe we are creatures of the environment we shall no longer struggle. Some of us, however, do make a fight against fate, and in spite of circumstances, we win. In this manner, it seems to me, we can make our ethical thought bear upon human evolution. 


\section{Professon Henry S. Drayton:-}

It is not well to assume too much for the theory of evolution as applied to man. Let us dwell upon some doubtful points. It is easy to overstate theories. Let us first be sure of our facts. Haeckel, and those of his school, present a very beautiful theory of the descent of man, tracing rescmblances to man in the lemur, the orang and the chimpanzee. They compare the gorilla to the degraded Australian; the Papuan and Negro to the chimpanzee. But it cannot be truly said that those animals possess the attributes of these races in any striking degree. The cranium of the dog is more delicately organized than that of the highly favored ape from which man is supposed to be descended. The embryonic argument, too, is apt to be exaggerated. The embryos resemble each other for a time- but the significant fact is that they begin to change. Why? Professor Von Hartmann of Berlin says that there is a wide difference in intelligence between the lowest man and the anthropoids. Man is capable of indefinite education, while animals are not. Again, man's immediate progenitor has not been discovered. Why not? The division of the hyoid bone to which Professor Cope has alluded has been found to be a characteristic of the ancestors of the Zuni Indians, and still influences the peculiar voice and cry of the natives. In civilized man this bone has become solidified. Man is less perfect than many of the animals in many of his organs and fumctions. Why is this so if man is the highest product of evolution? Sir John Lubbock says the anthropoid ape must yield the second place to the ant in the order of intelligence. The monkey must give way to the ant-he camnot toe the line.

\section{Dr. LEWIS G. JANES:-}

Professor Cope has spoken of man's ability, through his own volition, to protect himself from the irarsher features of the operation of the law of natural selection, which appears fraught with so much pain, evil and loss along the lines of vegetable and animal evolution. I believe no one has called attention to the fact that Mr. Spencer, in his "Essay on the Law of Population" and elsewhere, brings out the idea that the law is self-correcting, so to speak; that there exists in the nature of life a tendency which in hnman society will ultimatcly relieve man from the severest stress of the struggle for existence. As intelligence becomes more active in man and all along the line of animal evolution, we find that the tendency to increase of population diminishes; so that, according to Spencer, there will come a time when the evil will 
right itself - when there will be a condition of equilibrium, when each individual will have an opportunity of developing every bodily and mental faculty without interfering with the equal opportunity of others. I throw out this suggestion merely as a provocative of thought; I will not pursue the subject farther at the present time.

\section{Professor Thomas Davidson:-}

I only wish to express my strong agreement with Dr. Drayton. I do notbelieve that form is any guide, necessarily, to intelligence. The mere fact that the ant, which is so small compared with the ape, stands next in intelligence to us, seems to me to prove that intelligence does not at all depend upon structural development. I am very little acquainted with the facts of biology. I was much interested, however, a few years ago, in reading an article by Professor Virchow, in which he says there is no proof whatever that man is descended from the ape. He denied the descent totally. I am only surprised to hear such a man stand up and make this assertion in view of the general acceptance of the contrary opinion. I should like to discuss this question of the relation between mental power and physical development. How far are they subordinate, one to the other? All evolution of structure has been the product of a moving force - the "growth force," as Dr. Cope terms it. That is just what Aristotle said: "The man learns the thing by doing, and as he does his physical strength increases." So all physical structure is the result of doing. One of the strongest motives to right action arises from a clear insight into this fact, that the human being is what he does; and as he acts so in the end will he be.

\section{Dr. Robert G. Eccles:-}

Professor Cope has referred to those animal and vegetable forms which through inaction and lack of variety in environment, become sessile - they cease to grow. Some minds are affected in the same way. That is the trouble with Prof. Virchow-almost the only man eminent in science who can be quoted as anti-evolutionist: he is sessile. We had an eminent man in our own country who was similarly afficted-Prof. Agassiz. He did not accept evolution: he was sessile. Much of the criticism on the doctrine of evolution this evening has proceeded from a misapprehension of what it actually claims. No living thing is evolved from another thing now living. The apes have had their line of development, and man has had his. The attempt to trace man from the ape as 
it is now known is not true evolution. True evolution must consider that apes have themselves changed since they branched off from the ancestra line of man.

Our attention has been called to the fact that man's structure is not so perfect as that of lower animal forms. That is exactly as we might expect. If other animals have special tendeneies, as Dr. Cope points out, they must develop special organs and adaptabilities; so we must expect to find in man many organs and faeulties that we do not find in the lower animals, - some faculties more highly developed, others become rudimentary from disuse,-and vice versa. The nose of the dog is far more acute in pereeption than that of man. Special needs have produced special developments, each in its own line. This, so far from being an argument against evolution, is the strongest possible argument in its favor. The intelligence of the ant has been adduced in opposition to evolution. The fact is, there is no special structure that can be said to be a structure of mind. Evolution is not confined to one form or type. You can perfect two different instruments in two different directions; you can produce like results by entirely different means. The intellect of the ant and that of man manifest themselves through different media. A certain organism may be necessary to produce a eertain kind of intellect, but Nature is not limited to any one line of operation.

In listening to Professor Cope to-night, I am reminded of all that he has done toward the revival of Lamarck's theory of evolution-he has done more for this theory, indeed, than Lamarck himself. The appearance of Neo-Lamarekism in biology contemporaneously with Neo-Kantism in philosophy, is a very interesting fact.

I must eall your attention to the fact that the human structure is not made for an upright being at all: it is made for a quadruped. The arrangement and suspension of eertain of the internal organs in man, and especially in woman, is such that they are perfectly adapted to a quadruped. If a human being had made man as he is, we should have said that he did not know what he was about. The diseases from which the fair sex suffer are to a considerable extent due to the fact that the organs of the pelvis were intended for a being walking on four feet. We have not yet adapted ourselves to the upright position.

Then again, in the quadruped, the valves in the arteries and veins are so arranged that a perfect circulation of the blood is indneed. Along the back, which is longitudinal, the foree of gravity is sufficient to keep the blood in its proper channels. There is no need 
of valves, and there are none. But in man, who stands erect, and does need them, there are none either. Elsewhere in the human body we find them where they ought not to be, and fail to find them where they ought to be. These imperfections of structure are the fertile causes of diseases in man. On the ground of intelligent design and manufacture, these things are not explainable; but on the ground of evolution, their significance is clear.

Captain O. F. Burton:-

Some forty years ago, I was on the coast of Australia, and I saw the natives of that country. I saw monkeys also. I observed little resemblance between them. Will Professor Cope state when the change from monkey to man began? This Darwinian theory of the origin of the human race seems to me lower than the Mosaic theory. It is more umreasonable than the Christian miracle of the Immaculate Conception.

\section{Professor COPE :-}

In our theories we must leave room for and expect additions to our present knowledge. Hundreds of species of apes have existed, but knowledge of them is not yet complete enough to enable us to determine from what variety man is descended. Fragments of skeletons have recently been found in India which may throw light on the subject. Men not familiar with comparative anatomy cannot readily understand the resemblances between man and the lower animals; they think that because a gorilla, for instance, is hideous in external appearance, he cannot resemble man. These resemblances consist largely in similarities in osseous structure, the number of teeth, etc. The resemblances between man and the ape are found in varying degree in the different races, each with some peculiarity more marked than with others. On the whole, the Bushman presents the greatest number of similarities to the ape. To one having a knowledge of comparative anatomy, and comprehending the facts bearing upon this question, there can be no doubt whatever that man has been evolved from a lower animal form. The evidence is all one way, and is conclusive. 



\section{EVOLUTION OF THE MIND}

BY

- robert G. ECCLES, M.D. 


\section{COLLATERAL READINGS SUGGESTED}

IN CONNECTION WITH ESSAY VIII.

Spencer's Principles of Psychology; Fiske's Cosmic Philosophy; Daniel G. Thompson's System of Psychology; Lewes's Problems of Life and Mind; Bain's Mental Science and Mind and Body; Maudsley's Physical Basis of Mind; Clifford's Seeing and Thinking; Darwin's Expression of the Emotions in Men and Animals; Lindsay's Mind in the Lower Animals; Romane's Mental Evolution in Animals and Mental Evolution in Man; Binet's Psychic Life of Micro-Organisms. 


\section{THE EVOLUTION OF MIND.*}

THE mind - where is it, what is it and whence came it? For ages men have striven to solve these knotty problems. In studying the physical universe, we find that mocking nature played some solemn pranks, which if repeated in the psychical will account for our tardiness of progress in this direction. Inmediate perceptions of sense have almost invariably been illusory. The earth seems flat and at rest, but is round and in rapid motion. The blue dome above looks like a solid arch studded with specks of light, but is in reality immense vacuity with myriads of giant globes. The sun appears to rotate round the earth, but the earth goes round the sun. All we see seems as if out of us but is in reality pictured in the brain. $\dagger$ Science and theology clasp hands in declaring :

"This earth is but a fleeting show

For man's illusion given."

It required centuries of thought to triumph over the deceptions of matter. It may require other centuries to overcome those of mind. The controversy of idealism versus realism is not yet permanently settled, $\ddagger$ and there are others. of great importance that it will take many generations to make clear.\$ Of our own minds we have direct evidence. We can only know that other minds exist by our interpretations of the movements of matter. Because of this, physical science had to precede mental. In tracing the leading features of the genesis of the first, we may derive hints as to how we should approach the last. Before men began to philosophize and build up systems of thought it is reasonable to suppose that like children they took appearances for realities. Such a mind would take it for granted that the disappearance of a body of matter by vaporization was its. total disappearance, and its reappearance by condensation

* Copyriont, 1889, by The New Ideal Publishing Co.

† Reichert's Foster's Physiology, pp. 702-704.

Huxley's Critiques and Addresses, pp. 310-317. Mind, Vol. 7, pp. 30-54.

$\S$ Bascoin's Psychology, pp. 380- 401 . 
its creation. When they began to see that these changes were mere metamorphoses, philosophy was born. 'The impressions of sense became connected by speculation.* For ages after this, hypothesis after hypothesis was evolved as to the origin of matter from one or more primal forms. $\dagger$ All this time they went on committing the same blunder with energy, as had been done with matter. Heat, light, sound, motion and other modes were under incessant observation, but no effort was made at connecting them together. They saw motion only as gross and rectilinear. Even as late as our own age, no less a man than Mayer believed that motion ceased when it became heat. . Now we see motion everywhere, and the Universe appears as a

"Rushing metamorphosis o' erturning all that stable is,

Melts things that be to things that seem, and solid nature to a dream."

The advent of the doctrine of the Correllation and Conservation of Forces made it possible for Mr. Spencer to formulate the philosophy of Universal Evolution.§ Our belief in the indestructibility of matter and continuity of motion, are but phases of our inability to conceive of the non-persistence of the force of which they are manifestations. $\|$ But this inexpugnable reality has another aspect than its dimensional one. I An appreciation of this fact admonishes me of the utter fruitlessness of the effort at giving a clear conception of the evolution of the mind to those who pretend to believe in the incessant creation and amnihilation of psychic states. As looking behind matter to the persistent underlying reality forces us to believe in its indestructibility, so an application of the same method of reasoning to mind leads us to an identical conclusion. Divide matter as we will, we must at every step perceive that the pieces still have dimensions.** No jugglery of thought can conceive of two non-dimensional halves uniting to make a dimensional whole. Precisely the same kind of an impossibility of thought greets us in psychology. Divide mental or psychic operations as we will and we must at every step perceive that it must remain psychic still. No jugglery of

* History of the Inductive Scicnces, Y'ol. 1, p. 43.

$\uparrow$ Rodwell's Birth of Chemistry, 1)1. 13-29.

+ Tait's Recent Advances, 1. $5 \dot{5}$.

\$spencer's First Principles (Appleton, 1873, p. 185).

II Ibid, pp. 179, 184.

T Fiske's Cosmic Philosonhy, Tol. 2, 1'). 414-451.

** Cooke's New Chemistry, pp. 35, 36. 
thought can conceive of a psychic state coming from two or more non-psychic ones.* The human race has and car have no other basis for its belief in the indestructibility of matter than its inability to conceive of the non-dimensional becoming dimensional or the dimensional becoming nondimensional. The weighings and measurings of the chemist are never accurate enough and never can become accurate enough to prove that minute traces of matter are not at every transformation created or annihilated. $\dagger$ If, then, the impossibility of conceiving dimensional body as becoming non-dimensional is a sufficient guarantee of matter's eternal indestructibility, by what process of thought can we reasonably hold to a belief in the incessant destruction and creation of soul-power? No one can conceive of feeling or thought coming from that which has no element of either in its composition. Dimension can only be explained by dimension, awareness by awareness, and motion by motion. We can conceive of no adequate cause for extended body but extended body, for awareness (psychosis) but awareness, or for motion but motion. They are our last possible analyses of the phenomena they represent. $\ddagger$ Evolution as related to these is grossly misunderstood by many of its believers. Matter evolves, motion evolves and mind (psychosis) evolves, but we have no evidence that any of them are created. They merely change from low to high manifestations. That is the totality of what constitutes evolution. $\$$ It is simply a re-arrangement of what is. This trinity of extension, motion and psychosis are, on examination, unknowable without each other. We cannot think of mind without thinking of something having that mind. We can know nothing of that something without mind. Mind sends us to extended body for an explanation of itself, and extended body sends us to mind for all explanation of itself. In but one way is reconciliation possible. We can view them as dual aspects of a common persistent reality. This you may call by any name you please, but Mr. Herbert Spencer rightly designates it "The Unknowable." my brain you could see matter only, whereas when I look toward the same reality, only mind is perceived. The san-

\footnotetext{
* Spencer's Psychology (1872), Vol. 1, pp. 157, 158.

† Nature, Vol. 9, pp. $420-48 t$ (H. Spencer and Prof. Frankland).

$\ddagger$ Ibid, Vol. 10, p. 3 (Herbert Spencer).

§ Ribot's English Psychology, pp. 127, 128.

¿Spencer's Psychology, Vol. 1, pp. 161, 162.
} 
guine flood of the circle of Willis may surge and beat in unison with my heart, but all unknown to me. The rush and whirl of volitional and sensory nerve-force is in incessant play, but I know it not. The believer in special creations can hold to a belief in mind as separate from body, but the evolutionist must accept the doctrine of one persistent reality that subjectively is mind and objectively matter.* Now of this something - the "ding an sich" of Kant †- materialists try to wipe out the subjective aspect, and idealists the objective. It is as if two men should quarrel about whether the glass of a bottle all belonged to the outside or inside surface of it. It lies between both, but is neither. So long, however, as the glass persists, it will have opposite faces. So long as the unknowable persists, it is rational to believe that it will ever have an objective and a subjective aspect. If in sleep and coma mind is a total blank, creation must be a common occurrence and evolution an unnecessary explanation. That the sleeping is different from the waking state is evident, but as to how much different, and how different, careful study alone can determine. Awake and in a comfortable room, we give no attention to the temperature, the atmospheric pressure, or our own breathing. Let any of these be disturbed and we know it immediately. In our sleeping moments may not our consciousness of all environing forces be of this suppressed, non-attentive kind? Men sleeping amid noise will awake if it ceases. On stopping a railroad train all its motion changes into heat. But heat is motion too. When the molecules of the train all go together along the track we call it motion. When they individually vibrate at a given speed we call it heat. May not the sleeping and waking states of consciousness bear some such relationship to each other? Let us try an experiment. Here, we will suppose, is a sleeping boy. "Berty!" I call, but there is no reply. "Berty!" I repeat, and he simply moves. In louder pitch, "Berty!" is once again repeated, when he awakes and asks, "What is it, papa?" Did he hear first and then awake, or clid he awake first and then hear me? If he first heard me and then awoke, he could not have been psychically asleep. If he awakened first and then heard me, the call took no part in his awakening. As the call did waken him, he must have observed a change in the

* Fiske's Cosmic Philosophy, Vol. 2, pp 448-449.

† Muller's Kant's Critique, Vol. 2, pp. 112-114. 
psychic state, to which he immediately turned attention. Should all the watches and clocks in a jeweler's store sucldenly stop, the jeweler would know nothing of it, if it did not change the condition of his awareness. Years of habit made him indifferent to the sound, so that he did not observe it; but the instant it stopped he was aware of the change. Let us next suppose it to be Christmas, and that Berty has received a long coveted toy which he is intently studying. In his abstraction he fails to observe our approach. "Berty!" He does not hear. We repeat the name and he slightly moves. Calling in a louder tone, he hears and comes forward with his, "What is it, papa?" His attention was in the thrall of an intense pleasurable sensation. Mental abstraction and sleep are here seen to be analogous. In both, attention is riveted upon a pleasurable experience. "God bless the man that first invented sleep," is an expression acknowledging the pleasure it affords. Awakened often, an unsatisfied sleepiness is always present. The intensity of slumber is directly proportioned to its degree, just as the intensity of abstraction is proportional to the mind's interest in the topic contemplated. Waking abstraction allows many elements to enter, so that it is much less perfect than that condition of sleep where a single feeling sways. Coma has a feeling peculiar to itself, and the persistence of this feeling, if attention is turned upon it, is the persistence of the faint. Soldiers in the excitement of battle forget serious wounds, but as soon as attention is turned upon them they faint. Conscionsness in each of these cases alters its state, becoming what might be called sub- or infra-consciousness. The knowledge acquired in such a state would be such as that which Mr. T. Davidson has called anoetic.* It is an awareness of which we are not fully aware until we have another kind of feeling with which to contrast it.

The physiologist has found in the amøba the solution of all the problems of his science, since that lowly organism, like a white blood corpuscle, contains in the simplest form every property of all the higher organic tissues. $\dagger$ Nerves and muscles, bones and ligaments, are composed of cells, each of which through generations of differentiation has heightened some one of that creature's qualities in itself. $\neq$ Bodily development became possible through a division of

* Mind, Vol. 7 , p. 505.

† Reichert's Foster's Physiolgy, p. 14-16. $\doteqdot$ Ibirl, ]1). 18-22. 
labor among them, with a consequent exaggeration of some amoboid power in one set, and another in another. No new qualities were added. It would be contrary to the simplest implications of the doctrine of evolution to deny a psychological parallelism to this physiological fact, wherever and whenever the first traces of mind can be seen. For a few years past there has been a strong tendency among some evolutionists to look upon consciousness as an unnecessary accompaniment of automatons like men and animals.* It does not seem to strike such reasoner's that the fact of its slow selective improvement proves its utility. $\dagger$ Reflex action is their universal solvent of all physiological difficulties, but they seldom pause to inquire as to what reflex action itself may be. In the simplest forms of life facts appear that transcend all purely mechanical explanations. Machunes make neither judgments nor choices. An amœba in search of food pursues no haphazard methods, but makes most careful selections of the kind it wants. It will send out its pseudopodia, catch, swallow and digest a struggling infusorium $\ddagger$ or other mutritious game; but a mere touch of a grain of sand satisfies it as to its character, when it thrusts it from it in a way that plainly says, "That's not good." \$ Oxygen-consuming bacteria will cluster around grains of chlorophyll if exposed to direct sunlight, but pay no attention to them in the shade or darkness. They know when the oxygen is being given off. Engelmann is able to detect the presence of the trillionth part of a milligram of oxygen by the behavior of bacteria.\| Infusoria guide themselves in hunting their food with apparently as much precision as fish. They avoid obstacles, and sometimes undertake to move them out of the way. 'They carefully examine floating particles to determine their edibility. They reject the inmutritious, and take the mutritious. $\uparrow$ Hunter-ciliates, after destroying their prey, search right and left in every direction for it. After hunting some time, if they fail to find the shattered victim, a new race is begun for other pabulum.** Didinium will attack Paramœcium aurelia, but not Paramœecium bursaria, thus showing a knowledge of the distinction of species. $\dagger \dagger$ Troops of Bodo-caudatus will attack animalculæ many times their own size. A Colpod thus at-

* Pop. Sci. Mon., Vol. 5, pp. 722-734 (Huxley).

† Mind, Vol. 4, 11). 3-6 (James). $¥$ Pop. Sci. Mon., Vol. 6, p. 758 .

\$IcCormack's Binet's Psychic Life of Micro-Organisms, p. 41.

I| Op. Cit., 1). 32, $33 . \quad$ क Ibid, p. $46 . \quad$ *** Ibid, 1. $48 . \quad$ † Ibid, p. 53. 
tacked looks like a horse surrounded by a pack of hungry wolves.* These facts teach us that the psychic life of even monocellular micro-organisms is exceedingly complex, and that we must go lower still to discover the dawn of awareness. As Haeckel in speaking of Bathybius said: "Life is not a result of organization, but vice versa," $\dagger$ so these facts evidently teach that mind is not the result of a nervous system, but vice versa. Mr. Spencer's illustration of the evolution of the Social organism, $\ddagger$ points out in most emphatic terms the serious character of the blunder made by Professor Romanes in handling the subject of the Evolution of Mind.\$ His chart purports to give the exact point on the ascending scale, where the various mental faculties appear. Memory he first discovers among the Echinoderms; surprise, fear and the primary instincts among Annelids and insect-larvæ; the secondary instincts among spiders and the like. Using his test of choice as evidence of psychosis, the verdict is against his conclusions. Infusoria flee from danger, display fear and exert choice. As a savage comports himself more rationally toward his environing friends and foes than many nations do toward other nations, it is not to be wondered at that single-celled beings are more intelligent than those myriad-celled ones in whom adjustments of the composing units have not become perfected. To the latter, too, a new universe is being opened up, and its successive steps of organization are adaptations to the same. The forces which we have resolved into color and sound, taste and odor, form and structure, harmony and discord, land and water, sky and air, day and night, summer and winter, etc., are all a confused, undifferentiated jumble of energies playing on the surface of an amœba, and but little if anything more to a jelly fish. It is the resolution of this confusion that constitutes the evolution of mind in polycellular creatures. Prof. Wm. James says : "The world we feel and live in will be that which our ancestors and we, by slowly cumulative strokes of choice, have extricated out of this, as the sculptor extracts his statue by simply rejecting the other portions of the stone. Other sculptors, other statues from the same stone! Other minds, other worlds from the same chaos! Goethe's world is but

* Ibid, p. 60 .

† Pop. Sci. Mon., Vol. 11, p. 652.

$\ddagger$ Illustrations of Universal Progress, $384-428$ (1873).

$\$$ Mental Evolution in Animals, D. Appleton \& Co. 
one in a million alike embedded, alike real to those who may abstract them. Some such other worlds may exist in the consciousness of ant, crab and cuttle-fish." $*$ 'To awake to a realization of the world as we know it, the evolution of our organs of special sense became necessary, and paripassu therewith, our nervous system. Effects always succeed causes. Our organs are all effects, and consciousness in some form the necessary antecedent. That eyes were made for seeing and not seeing for eyes, seems to be the only rational conclusion for an evolutionist to reach.' It is easy to picture to ourselves a God making an eye and then putting a soul behind it.to see through it. It is not possible to picture evolution doing the same thing. An eye represents millions of selections utterly useless and even injurious to a nonseeing being. The fact that these accumulations have occurred, is itself proof of a seeing power preceding eyes. Natural selection does not operate by accumulating useless and injurious things. If there was, from the very start, something present capable of seeing, every little change aiding it in this, would become a benefit to the whole organism. What is true of the eye is equally true of the ear and the organs of taste and smell. The very first step. taken toward any of these, could only have been preserved because it answered the requirements of a pre-existing consciousness. $\dagger$ The fortuitous production of things so perfect. is not for a moment to be considered. 'They satisfy a demand that preceded them. Within the eyeless, earless, noseless, mouthless protoplasm, existed that which was psychically capable of obeying the law of evolution by changing from indefiniteness to definiteness, from incoherence to coherence, from homogeneity to heterogeneity. $\neq$ The jumble of physical forces played upon it, and produced within it a. chaos of impressions to which no definite attention was applied. Slowly, changes occurred, with ever increasing perfection, that brought out a distinction between light-waves and sound-waves, between tastes and odors, between heat and cold. Corresponding to the material integration. into a nervous system, was a psychic integration into an ego; and answering to the dissemination of motion was the disappearance of conflicting tendencies of cells. Thus.

* Mind, Vol. 4 , p. 14.

+ Vide Prof. Cope on Catagenesis, in A merican Naturalist, Vol. 18, p. 972.

$\ddagger$ Spencer's First Principles of Philosollhy, 1)1. 3!4-396 (1873). 
we perceive a perfect parallelism between the production of the subjective and objective world. No such parallelism, however, can be discovered by those who believe that consciousness was out of the succession at any point. The arrangements of our cells, the tortuous anastamoses of our veins and capillaries, the striation of our muscles, the reticulation of our connective tissue, the mechanism of our bones, the arborescence of our nerves, and the whole grand miracle of our organic complexity, is but a wonderful history of the development of higher and higher psychic power. Millions of vibrations may resound within this fretted network, but only the grand resultant is perceived as a feeling of wellbeing. A break in the harmony attracts attention by discomfort, and many breaks constitute the feelings of disease. As the driver of a many-horsed stage holds lines to every horse by which to guide them, so the central will appears to be comnected with every part of the body, psychically as well as physically.* This coenæsthesis constitutes the background of the minds of higher animals, while the organs of special sense provide the data of knowledge. In reaching up to these possibilities of our intellect, a long chain of pains and pleasures were the guiding impulses. Comfort is the state forever sought by every creature. A condition of comfort or pleasure is the concomitant of evolution, while one of discomfort or pain means dissolution. $\dagger$ We cannot conceive of organized existence under conditions other than these. To like that which injures the system is to journey toward dissolution. All injurious external relations are to organized beings more or less painful. The mind is therefore incessantly seeking to adjust the body in a way that will increase its pleasure or diminish its pain. The more perfect this adjustment the more perfect the life of the creature. $\neq$ In watching the movements of an animal, we judge its place as high or low on the mental scale in proportion to its power of adaptation to its environment. We can as yet only in the roughest fashion make any classification in comparative psychology, although the thing at first glance seems simple. The fact is, we know very little about how speechless animals feel or think. Many of them seem to possess powers of adjustment in special directions that far exceed our own.

* Luy's Brain and its Functions, pp. 91-101 (Int. Sci. Ser.)

† Spencer's Psychology, Vol. 1, pp. 272-288.

† Spencer's Biology, Fol. 1, pp. 82-93. 
Examples are found in the dog's power of smell, the eagle's. power of sight, the ant's power of tunneling and the ability of clomestic animals to find their way back to their old haunts by a direct route hundreds of miles long and that is entirely unknown to them.* A fly surely cannot, with its compound eyes, see the world as we do. $\dagger$ Its psychic method of adjusting bodily movements to its enviromment cannot be like ours. However diverse its mental make, or that of any other creature below us may be, we certainly do observe a. serial character within the grand total. The differentiation of organs of sense from simple surface feeling seems to be a fair inference from observed facts. In the lowest forms we find the sense of touch their only visible avenue of knowledge. In the higher ones we find fully developed special senses. Between these extremes we find many degrees. The lowest can know but little beyond themselves. The highest can study the myriads of stars that dot space, as to their physical and chemical conditions. There are many degrees between. The sphere of known space expands with the development of the mind and organs of sense.f Observation likewise reveals the fact that mental progress in the knowledge of time continually adds itself to the knowledge of space. While men of high intelligence are provident and careful, looking ont for all possible future contingencies that might bring them suffering, the less intelligent show less such forethought.\$ The farther down the scale we travel, the less and less this mental trait is revealed. Prevision is a constantly developing power. The prophets of to-day are greater than those of the past. With the advance of science, our power of prediction increases, and we become enabled to look farther and farther back into the past. With this development in the knowledge of time and space, goes a development in the discovery of differences between things that at first look the same.\| This growth in specialty of mental correspondence with the world without, lies at the very base of knowledge. Every fact in every field of thought is but an experience, labeled with a name to distinguish it from all other experiences from which it differs. $\uparrow$ It is evident that the totality of experiences in

* Mind, Vol. 5, p. 581.

† Spiencer's Psychology, Vol. 1, p. 318 .

$\$$ Ribot's English Psychology, pp. 162, 163 (Spencer).

iI Spencer's Psychology, Vol. 1, 1'p. 329-341.

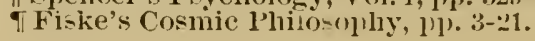


qualities and kinds must become greater and greater with the progress of the senses. Eyeless animals cannot distinguish between red, green and violet. No such experiences are ever known to them. Reasoning and experimenting beings extend this correspondence to an enormous extent. With the accumulation of facts of difference, are soon observed facts of resemblance among things otherwise very much unlike. The discovery of these establishes new groups of mental relations answering to such outer conditions.* From the simple, we go on to the complex. The generalizations of science transcend the mental power of the rustic in their broadness, and he has but little conception even of their number. His well founded reasons for certain of his acts and beliefs would seriously puzzle a savage, while the thoughts and deeds of the latter would be equally mysterious to a chimpanzee. The subsuming of isolated facts into higher and higher classes has been going on from the amœba to man. The highest and last great generalization, that of evolution itself, is but the latest stone laid on the walls of a temple whose foundation was laid by the lowest possible efforts in the generalization of brutes. To consider therefore that our mental powers were born in a cradle of darkness and sorrow, nurtured amid the eruel throes of agony, $\dagger$ and that step by step has been one continuous series of triumphant gains of peace and joy, should make us proud of our humble lineage, and prouder still of that final goal whither we trend. In the deep, unutterable longings of sanctified hope, one incessant, heartfelt prayer has resounded down the ages from the primitive amœba to the civilized man. Devotion so continuous deserved and has received a large reward. Our Newtons and Spencers, Kants and Darwins, Goethes and Shakspeares, are but the first fruits of a harvest whose coming bounty no husbandman can compute. $\ddagger$ There have been no leaps along the line, no letting in of new elements. An unbroken continuity is everywhere discernible. "The most elevated phenomena are the effects of a complication that has come out of the simplest elements by insensible degrees." \$ From fundamental indivisable awareness, with its memory, feeling and will, have come perceptions and conceptions, judgments and imaginations, instincts and reasons. These are all but

* Spencer's Psychology, pp. 3ł2-319.

† Proc. Amer. Assoc. Adv. Sci., 1883, pp. 41-48.

$\ddagger$ Pop. Sci. Mo11., Vol. 7, pp. 61, 62. \$ Rilot’s English Psychology, p. 164. 
artificial subdivisions of a continuously connected whole, whose invariable aim is correspondence with the environment. Every successive step seeks to tix an exact parallelism between the order of our mental contents and the order of the forces of nature.* When external relations and internal conceptions have become perfect correspondences, intelligence will be at its highest. Life will have become unending when adjustments are as perfect as this knowledge. In studying this parallelism between the contents of the mind and its environment, we should not forget that the inner is only symbolic of the outer. It has been wisely said that "We are fearfully and wonderfully made." The grotesque notions of our fathers and the fantasies of the savage are far short of the great reality. But few grasp what the mind does. They never pause to consider that all that is grand in so-called objective nature is but states of their own consciousness. $\dagger$ The actual universe without is unknowable.f Knowing is the mind's special function, and all we know is in, and not out of it.§ Within its sacred precincts is focalized the dazzling brilliance of the glittering dome of space, the weird loveliness of the mountain landscape, the verdant flower-bespangled prairie, and the vast, surging waters of the ocean. The physicist resolves the outer phase of the correspondence into motions, and the psychologist the inner one to feelings. In the attempt at making such a resolution, however, a vast amount of mental confusion exists. We speak of the brain as the organ of the mind, and yet very few have any definite idea as to what they mean by this. The eye is the organ of sight, yet the eye is not the seer.\| The ear is the organ of hearing, yet it is not the hearer. The brain is the organ of thought, yet there are many facts that go to show that the whole brain cannot be the thinker. The great bulk of that organ (or rather combination of organs) appears to be related to the thinking process much as the eye is to the seeing one. The comparison of symptoms in the living with post-mortemfound lesions of the brain, and the careful experiments upon animals by Ferrier, 9 McKendrick, ** Goltz, $† \dagger$ Burden-San-

* Spencer's Psychology, pp. 407-417.

$\dagger$ Huxley's Critiques and Addresses, pp. 285-317.

† Spencer's First Principles, p). 85-97.

$\$$ Bernstein's Five Senses, p. 16\%. || Ibid, 1. 3.

If Ferrier's Functions of the 13rain, 1),. 280-318.

** Tran's Roy. Soc. Edin., 1873, article on Exper. on Brains of Pigeons.

i† Ferrier's Functions, 1. 258. 
derson,* and many others, have fixed definitely some functional areas. $\dagger$ When neurologists can tell positively from a patient's symptoms the location of a cerebral abscess, and remove the same with a minimum of injury, what greater evidence can we ask of the truth of some of their discoreries? A large part of the brain unfortunately still remains "a dark continent." Certain regions preside over sensation, $\neq$ and certain others over motion. $\$$ No center of distinct consciousness has been fixed upon. If such a place exists, the area would seem to be exceedingly small, if we nay be allowed to draw inferences from introspective observation. At any one moment the knowledge immediately under attention is exceedingly minute, as compared with the large amount stored away by retention. We can only know a very few things at a time. If the area of mental synthesis is as small in proportion to the total brainmass as the amount of knowledge we call at once be conscious of is to the total knowledge stored up for use, then it is very small indeed. That consciousness is not all over' the brain at once is seen in the fact that we are not always aware of everything we ever knew or now can know by introspection. If that was the case, forgetting would be impossible in a brain free from lesions. Unconscious cerebration could not be possible. Experience daily indicates to us that the brain is like a book. Consciousness looks into it at various points, reading its contents, or else currents come from such points to be translated into knowledge at some center of synthesis.\| All we know of evolution emphasizes the fact of division of labor and the production of higher and higher centers of control over that below. Anatomy exhibits an organic arrangement that physiology has thus interpreted as far as it has gone. That a center of attention should exist where all sensational elements could be put together, would seem to be but a fair inference. Ferrier places such a center for man in the frontal lobes. I Attention is the uniting link of motor and sensory activity, and takes part in every mental act however high or low it may be. It is a form of will; and the frontal lobes may only be related to it in the production of mental work as the

* Calderwood's Relations of Mind and Brain, p. 105.

$\dagger$ Luy's Brain and its Functions, pp. 39-41.

† Ferrier's Functions, pp. 180-188. I Ibid., pp. 226-256.

II Morrison, Relations of Hind and Matter, in Amer. Nat., Tol. 19, 1. 853.

T Ferrier's Functions, pp. 316-318. 
muscles are in physical work. As a man's power to execute the decrees of his will on brute nature varies with his muscular power, so does his power to concentrate his attention, and think, vary in proportion to the size of his frontal lobes. We found elsewhere how the mind obeyed the law of evolution by increasing its correspondence with objective facts in time, in space, in heterogenity, in speciality and in generality. Here we discover how it intensifies its activity and reaches toward more and more rapid strides in all these directions by the growth of the power of attention.

At the very base of its career this power must have been present. As Professor Cope has said, "Physical and mental development depend on the will."* To know, requires prolonged experience. $\dagger$ In the rushing stream of Time, what we call Nou is but an imaginary line ending the past and verging on the future. To know, includes the past. The absolute present without it is nothing. To embrace the past in knowledge is to remember, but it is also to use attention. Given attention and retained experiences, and we have awareness or consciousness. It may be the lowest type of consciousness, known to us as simple feeling. Will, memory and feeling are thus seen to constitute the indivisible psychic trinity. Matter has a similar trinity in its length, breadth and depth. The evolution of all material forms came by adding atom to atom in three dimensions. The evolution of mentality came by somehow making it possible to expand its three dimensions of feeling, memory or intellect, and will. $\neq$ How the first of the three grew into its heterogeneity of color and sound, taste and smell, heat and cold, is an unsolvable problem. We know that the difference between the objective causes of yellow and red is speed of vibration.\$ We do not and probably never will know how the sensation red changes into the sensation green. The same is true of all other sensations. No theory can be framed that will enable us to assimilate them. We may yet by successive analyses discover the psychic steps through which we reached ip from the lower to the higher, but farther than this we camnot hope to travel.

That a distinct mnity of composition exists between all our mental states is the positive implication of evoluticn.

\footnotetext{
* American Naturalist, Vol. 21, p. 1128.

† Ribot's Diseases of Memory, p. 34 .

$\ddagger$ Bain's Mind and Body, $11 \%$. 43, 44 .

$\$$ Lomell's Nature of Light, 1. 226 .
} 
Nothing is or can be known except resemblances and differences. They constitute the totality of knowledge in savan, savage, child, beast and insect, so far as can be discovered.* As the numbers, forms and arrangements of the molecules make all the differences between crystals, so the numbers, forms and arrangements of like and unlike experiences seem to make the differences between minds. These are all successively grouped in a way that causes psychic and physical relations to reach toward perfect correspondence. $\dagger$ All the separate facts in each individual fuse into a common whole, constituting the ego as it exists at any moment. That the substance of such facts is the brain-structure, there can be little cause for doubt; and that they are evoked as required, by streams of nerve-energy, appears to be equally clear. It therefore seems strange that immediate acts of consciousness are limited in the manner we find them to be. The whole brain no doubt takes part in thought, as the whole body does in feeling; but it is evidently in a mediate rather than an immediate manner. Its separate impressions somewhere fuse into the one persistent feeling of self. While the energy evoking the stream of consciousness flows from the whole brain (and indeed from the whole nervous system), the substance that is thus made conscious is some highly differentiated section of that organ. Viewed in this manner, a reconciliation is observed between the modern doctrine of reflex action of Carpenter, Maudsley, etc., $\ddagger$ and Lewes' belief $\S$ that the spinal cord is also conscious. It is quite certain that in spinal reflexes and in unconscious cerebration we take no part that we are aware of. It seems clearly proven that such acts display the signs we are accustomed to interpret as meaning motion, will, feeling, teachability, etc.

As recent researches seem to show consciousness among monocellular creatures, it would seem to be a fair inference to believe that polycellular ones by differentiation from these should have many centers with distinct autonomies. Lewes makes the whole nervous system a single sensorium commune. Maudsley makes the cerebrum the sole center of sensation. If If we agree with the latter regarding the

* Ribot's English Psychology, p. 175.

$\dagger$ Ribot's English Psychology, p. 189.

† Maudsley's Physiology of Mind, pp. 136-182.

$\$$ Lewes' Physical Basis of Mind, pp. 509-549.

I. Maudsley's Physiology of Mincl, pp. 244, 245.

\|l Ibid, p. 5556, §94. 
seat of our consciousness, we can still believe with the former that the spine is also conscious. As the consciousness of a superior officer is distinct from that of his soldiers, it certainly does not follow that the suspension of his consciousness is the suspension of theirs. Thus viewed, reflex action is the outer aspect of some form of psychosis. Instinct and reason, in evolving therefrom, made no breach of continuity. Viewed in any other light, the development hypothesis is discrediter. The present can only be a rearrangement of the past. Each step of progress is but a putting together of pre-existing elements of the same kind. This is seen in the production of our bodies. We are, in the light of biology, but a synthesis of the properties of protoplasm. An amoba can in an imperfect and small way perform every function of our bodies. Every new invention is but a putting together of pre-existing forms. Every new idea is a synthesis of old ones. The so-called discovery of truth is a growth of truth. The mind is incessantly constrained by pain and attracted by comfort into correspondence with its environment. It cannot reach the higher adjustments but through the lower ones. It never reaches perfect adjustment nor perfect truth; neither is it ever given over to total error. All its errors are partial truths, and all its truths partial errors.* The new truth of the future is the synthesis of the partial truths of many errors of the past. Reconciliation is progress. Experiences which give rise to narrow views are in time reinterpreted in the light of other experiences, and an expansion of the horizon of thought occurs. The growth is not from total error to perfect truth, but from a maximum to a minimum of error, and from a minimum to a maximum of truth.

In morality the same condition obtains. No creature, however low, is absolutely selfish, and none, however high, absolutely unselfish. $\dagger$ Unselfishness is itself but transformed selfishness. We are kind and good to other's because it is a greater pleasure to us to be so than it would be to pursue a course of selfishness. We relieve suffering and give charity because in doing so we free ourselves from sympathetic pain. $\neq$ In the sufferings of the past came our capacity for joy, in the struggles of the past our capacity

* Spencer's First Principles, p. 3 (1873).

† Spencer's Study of Sociology, p. 184.

t. Spencer's Recent Discussions, 11). 26, 27 (1873). 
to think. The pain and agony endured by our progenitors has attuned our systems to a thrill of pain at the sight of another's sufferings. On seeing a fellow-being suffer we mentally picture ourselves in the same state. This evokes a quiver of pain in us that is an incessant impulse teaching. mercy and leniency. To be cruel is to punish ourselves. As every step of progress is taken toward greater definiteness, this trait is likely to be a growing one, keeping pace with advancing civilization. Our minds will become keener in appreciating the suffering of our fellows.* This will heighten our pain at another's agony, and increase our joy when able to relieve the same. Nature thus seems bound to lay upon us her lash for wrong-doing until the race is willing to clasp hands as a common brotherhood. Such is the Gospel according to Evolution. 'The sense of right and wrong as mental traits is seen to exist in domestic animals, but with nothing like the definiteness nor heterogeneity it. has in ourselves. The more intelligent the being, the more numerous the shades of wrong-doing that can be perceived. Our morality transcends that of the savage, as his in turn transcends that of the brute. $T$ The evolution of Mind being, as before pointed out, an increase in correspondence between itself and the universe around it, the ethical aspect thereof would seem to be the coming one for future adjustments. At the very basis of known mental life, every act seeks to avoid pain and increase comfort. $\ddagger$ Each new mental power is a help in this direction.

On ascending above simple physical life to the intellectual, we perceive everything conspiring for the same common aim. Life is only worth living when it gives more pleasure than pain. The growth of intellect enables us to aroid many forms of pain, and the synthesis of pleasurable feelings of many kinds heightens joy. The highest form of such synthetic products is love. The elemental form of love appears in every pleasure of every kind, but its highest manifestation is altruistic. When intellect has become fully wedded to unselfish love, the ideal man will have appeared.§ Then happiness will be at its maximum, and the soul-felt desires of millions of generations will have been heard as prayers and answered as facts. Love is the high-

* Spencer's Data of Ethics, p. $249(1880)$.

† Fiske's Cosmic Philosophy, Vol. 2 , p. 350.

+ Spencer's Psychology, Vol. 1, p. 284, \$127 (1872).

$\S$ Spencer's Data of Ethios, p. 149 (1880). 
est manifestation of mental life. 'The mind throughout its whole developmental career has been reaching toward it and longing for it. All progress is and always has been in its direction. The gentle mother of all sings to us its lullaby, and our nervous systems are steadily being attuned to the refrain.

The following apostrophe was written many years ago, lut has not before been published. It accords with the line of thought which properly terminates my discussion of this topic.

Thrill on, O mystic neural threads ! Your sympathetic pulse is heaven

When wave wilh wave enraptured weds And hearts attractive bonds are given.

Attuned to God's divinest notes,

Yon stars such symphonies are sounding;

And atom unto atom quotes

This rhythmic cadence when rebounding.

Your quivering structures tell of love.-

The highest, purest, grandest motion ;

Your psychic transports soar above

Into the great supernal ocean.

Yes, throb in unison with all, To form a perfect diapason, That echoing concords may recall Thy tender, sanctified sensation. 


\section{ABSTRACT OF THE DISCUSSION.}

Dr. LEWIS G. JANES :-

By its careful attention this audience has manifested deep interest in Dr. Eccles' essay. As a treatment of the psychological aspects of the subject the paper seems to me to be one of an exceedingly high order, manifesting careful and accurate study and able and independent thought. I confess, however, to a certain measure of disappointment in that the lecturer has devoted so much time to clearing the way, and has not indicated in greater detail the successive steps in mental evolution, from monera to man. There were times during the delivery of the essay when it appeared to me that the Doctor's science and his metaphysics were engaged in a "struggle for existence," the outcome of which seemed a little dubious. I find myself wholly in agreement, however, with what I conceive to be his fundamental position. Natter and Nind are, as Goethe affirmed, "eternal double-ingredients of the universe." The Reality manifested in all phenomena must be regarded as a double-faced unity, revealing itself as matter to the senses, as mind in the operations of thought. I cannot quite accept the speaker's technical terminology, which appeared to me to confound consciousness with mind. I regard it, however, as only a phase or condition of mind, in which it is directly related to a somewhat external to itself. Consciousness, Dr. Eccles assumes, is not absent in coma, diverted attention, or profound sleep : it is merely concentrated upon a single dominant thought. I do not think that he will find the weight of scientific anthority to support this view. How will he account for the condition frequently resulting from fracture of the skull, when consciousness is apparently extinguished by the pressure of the bone upon the brain? A person in this state could not be aroused by repeated calling, as in the instances the speaker has adduced. Only one thing could restore consciousness - a surgical operation relieving the pressure. In such cases consciousness appears to "pick up its ravelled threads" at the exact point where it was interrupted by the injury. No one supposes, however, that the mind has been destroyed and re-created. Mill has defined matter as "the permanent possibility of sensation." In like manner I would define Mind as "the permanent possibility of consciousness." Every act 
of consciousness is subjecto-objective - a reflection of Self upon Not-self ; or, in self-conscionsness, it involves a differentiation of Self from Not-self. In its lowest, undifferentiated form, conscionsness is mere sentience; it apprehends the external world through the primitive undifferentiated sense of feeling.* Its inferences are crude and misleading on account of the limitations of its scope - though the knowledge which it actually gives is true knowledge. The evolution of mind proceeds pari-passu with that of the organism, by interaction with environing conditions. As higher stages in the evolution of life are reached, the revelations of the simpler forms of consciousness are not contradicted; they are simply added to, and thus the crude inferences of the simpler consciousness are corrected. The creation of either mind or matter is inconceivable from the standpoint of Evolution. All science assumes a realistic philosophical foundation. All knowledge is therefore real knowledge of a real universe ; it is real knowledge, though not complete knowledge - a knowledge of real relations in external phenomena, as really related in and to the individual consciousness.

\section{Professor Almon G. Merwin :-}

While interested in the lecture, I was, in a measure, disappointed. I had hoped to hear how the more complex states of consciousness grew out of the simpler, as manifested in the lower organisms - how the five senses, and a knowledge of the means by which we communicate with the outer world, were developed. Men have tried to change the vibrations causing sound into vibrations causing taste. What is the common substratum of mental substance underlying these different sense-perceptions? In many things I agree with the lecturer, but it seems to me-though I suppose it was unavoidable - that he was largely speculative in his theories and conclusions.

\section{Mr. Nelison J. Gates :-}

I had hoped that Dr. Eccles would give us more ideas with reference to the evolution of mind from the individual standpoint. Beginning with the single nerve-cell there is a development by the multiplication of cells. The steps in mental development have proceeded along corresponding lines, and must have been prececled or followed by a physical development. Will Dr. Eccles tell us

* I do not mean, of course, our specialized sense of touch, which requires a highly developed nerve-system. of the special senses there is consideralle evidence that sight was the first in order of evolution. Vide Binet, "The Psychic Life of Micro-Organisms." 
which, or if they are co-incident? It appears to me that mind did not precede physical development, as the lecturer has assumed, but that mind and matter have evolved in perfect unison - they are co-incident. They are one in ultimate nature and principle, and cannot be separated. We have to think of matter in terms of mind, and of mind in terms of matter. But I think Dr. Eccles assumed the idealistic position. 'That field had best be given over to metaphysicians - the professors of mental gymnastics.

The theory of evolution is one of the greatest ever offered to the human mind. Everything has existed potentially in the original material of the universe. There is no room for miracle in the passage from inorganic to organic matter. Phenomena are the result of pre-existing phenomena. It seems to me that we are compelled to believe that all force, and all physical and mental phenomena, are manifestations of one material substance.

\section{Mr. O. F. Burton :-}

The lecture of Dr. Eccles is one of the most masterly presentations of the subject I have ever listened to. I must disagree with Spencer's assertion that mind is unknowable. Millions believe they know mind sufficiently to come to a knowledge of the great Mind-God. I believe that magnetism is the greatest power in the universe. Its action on the brain produces the sensations of taste, smell, etc.

\section{Dr. ECcLes :-}

Beginning with the last speaker, let me say that Herbert Spencer has not denied that mind is knowable, but that, on the contrary, he has gone to great trouble to show that both mind and matter are knowable. He has written two large volumes - "The Principles of Psychology" - to show that mind is knowable, and to explain what is known concerning it. Professor Merwin is not satisfied because I do not explain the unknowable. He wants me to explain how sensation is transmuted into consciousness. That is the unknowable. It cannot be explained. Our data are not yet. sufficient to make a dissertation along the line suggested by Mr. Gates either profitable or interesting. That is a work that must be left to future investigators. I did not assume the priority of mind to matter, as $\mathrm{Mr}$. Gates inferred, but merely the priority of mental activity to functional and structural development in the organism - an entirely different thing. As to Dr. Janes' remarks about the illustration of the boy and his falling into unconsciousness, my contention is that consciousness is still there, but, as I 
have said, the attention is so powerfully attracted to the seat of pain that it cannot be withdrawn. I admit, however, that as far as the facts are concerned, they are explainable from either point of view. As to taking a lesson from the ants or any of the lower animals on this subjeet, it is impossible to show the organization of mind among them : we can only show that in them as in man mind is adapted to its environment. Therefore the method which I adopted seems to be the only one practicable in the presentation of this topic. 


\section{EVOLUTION OF SOCIETY}

BY

JAMES A. ȘKILTON. 


\section{COLLATERAL READINGS SUGGESTED}

IN CONNECTION WITH ESRAY IX.

Spencers's Principles of Sociology, Descriptive Sociology, and Social Statics; Tylor's Early History of Mankind; Coulange's Ancient City; Maine's Ancient Law, and Early Law and Customs ; Keary's Dawn of History; Force's Prehistoric Man; Lubbock's Primitive Condition of Man, and Origin of Civilization; Clodd's Childhood of the World; Bagehot's Physics and Politics; Morris's The Aryan Race: Its Origin and Achievements ; James Cotter Morison's The Service of Man. 


\section{EVOLUTION OF SOCIETY.*}

Either prospectively or immediately, the central figure in each one of the topics of the essays of this course upon Evolution is Man; and in its full scope, in the topic of this evening, the central figure is Associated Man, in process of evolution as such, in the presence and under the influence of earlier and rudimentary forms or types of societary association found in vegetal and animal life generally.

The largeness, complexity, and, in its early stages and history, the obscurity of the subject, therefore become evident at a glance. The experience of the Master himself illustrates the difficulties to be met with in its treatment. Whether or not it be true, as we suspect, that Mr. Spencer found in it the initial impulses that led to the working out of his system of philosophy, it is evident that all his previously written books lead naturally and inevitably up to those he has written on the subject of Sociology. And yet on reaching that branch of his system, in due course, he found himself practically forced to prepare a special and preliminary work on the "study" of it, devoted substantially to an extended examination and explanation of the almost insurmountable obstacles and hindrances to be met with in presenting and in understanding it.

Comprehensively, at the outset, he describes the entire objective and subjective worlds as fairly barricaded with them; and subsequently, descending to particulars, he presents and describes, through some hundreds of pages, like so many specimen grains of sand taken from an ocean beach, samples of "bias," with which the human mind is infested, such as the educational, the patriotic, the class, the political, and finally, worst of all, the theological bias, all of which interfere with the proper study and comprehension of the subject. He then occupies nearly one hundred additional pages in setting forth the "discipline," the "preparation in biology" and "psychology" required for the proper study,

\footnotetext{
* Copyright, 1889, by The New Ideal Publishing Co.
} 
ending with a "conclusion," and, in later editions, a "postscript" of some forty pages more. And when the end of the book is reached, the wonder of it all is, that he did not write finis, and drop the subject then and there forever. 'That he did not do so, is one of the many marks of his inperial genius.

In the preface to Part II, Vol. II, Principles of Sociology, Mr. Spencer says in substance that the full and satisfactory treatment of political evolution alone "would require the labors of a life," and that he therefore limits himself to broad generalization, believing it to be "supremely important and that no one part can be fully understood without it." But even he, treating the subject in this manner, has only been able to stagger on without going through, or completing it, and seems now to have fallen exhausted by the wayside, leaving his work in this branch unfinished, and, as we fear, never to be finished by him.

No further excuse need be offered for the various limitations of this essay. However, let any one sitting down now to prepare a sociological essay glance at the bibliography of the subject, and he will find that the work already done by Mr. Spencer has stimulated scores if not hundreds of able thinkers and writers into activity, as well as many others. whose writings may at least have the effect and merit of arousing the attention of some minds that would not otherwise be reached and influenced. Certainly any one interested in sociology, on looking into the books already on library shelves, and noting the yearly procession of them on the march to that position of influence, must be greatly encouraged by the rapid spread of evolution views in the sociological branch of the subject. Whether Evolution has yet fumished us with completely satisfactory solutions and remedies, or not, it has certainly rendered us a great service in disclosing some of the abysses directly under our feet; and particularly by more than warning us that the dark ages are not necessarily all behind us.

Especially in America it has done us a valuable service in developing a well-founded and healthy distrust in the wisdom of many of the old leaders and systems, and in preparing us to at least judiciously hope for, if not expect, the eventual coming of a better day. Particularly, it has aided other helps to knowledge, in assisting the suppression of the provincial bombast and self-sufficiency of the Fourth of 
July orations of the past and the early part of the present generation, with many of their implications, and also in showing us that our institutions have a solid support in a true science of society.

Many prior attempts had been made, with more or less of mingled failure and success, to reduce social chaos to order and system. Significantly, the dominant civilization of the modern world, and as we hope of the future, is based on the teaching found in what is claimed to be a sacred book, which opens the history of the world as beginning in a state of chaos, out of which the wonderful order and harmony of the celestial spheres were slowly developed under the control of a Supreme Power. In the concluding division of the same book, dealing with mankind born into a world as the product of this Supreme Power, the highest point is reached while dealing with fundamental social principles almost exclusively - religious worship being relegated to the closet, and there dominated by social duty-in the appeal of prayer to the same Power, containing the words: "Our Father which art in heaven. Thy kingdom come. Thy will be done in earth us in heaven."

Evolutionary Sociology not only follows the first example so set, by finding its fundamental principles in and through a study of the prior celestial chaos and its methods of reduction to cosmos, but it also follows at no great remove the remaining parts of that early account of creation as it deals with the development of vegetal, animal and human life on this globe - substituting only the slow-working principle of evolution for the quick-working assumption of creation, and reducing all of it to an orderly, scientific system ; and it also follows the later inspiration in applying the evolutionary principles found at work in the heavens, to the reduction of social chaos to beneficent order and harmony, insisting always and everywhere on their universality and omnipotence, both in the kingdom of heaven and in the kingdoms of the earth.

So doing — and so doing throughout — it is impossible for us to believe that the sacred book and the evolution philosophy can be found in serious conflict; and we are compelled to believe that they will, when properly understood and interpreted, be found in substantial harmony.

In the heavens, order arises out of seeming disorder, through the necessary development and developmental 
effects of antagonizing forces; and the order thus produced rises in grade, character, or quality, as these antagonisms increase in complexity and activity. Distinctive societary action, however, first appears in the domain of vegetal life. There we find the united and associated action of individuals of the same species resulting in the occupation and possession by them of large areas of forest and field, to the exclusion of other species, accompanied by struggle, conflict, slaughter, victory and defeat; all of which are continued between individuals of the same species without end. Between individuals and associations of different species even more severe struggles and conflicts universally prevail; and the tragedies of vegetal life may well be said to be not less than those recorded in the histories of the world, or those prior tragedies of human life unrecorded in any history.

Although the lily neither toils nor spins, yet when left to itself it is compelled to struggle for existence not only with others of its kind, but with other forms of plant-life having in their mode of action the principles and methods of the thief, the tyrant, and even the murderer. In fact, the remorseless struggle for supremacy among plants left to themselves, is everywhere evident to the most casual observer. Note what occurs after a great freshet in the Ohio River, when, as the waters subside, a new island is seen to have been formed by their action. The sun of the succeeding summer speedily develops, or aids in developing, numberless seeds and germs of the sycamore tree, scores of which peep out into the daylight through the drying crust on every square foot of the surface of the new island. Before the summer is over it will be discovered that some individuals, either by reason of superior vigor inherited by the original germ from the parent tree, or of the greater richness of the immediate soil in which their lot may have been cast, have grown taller than others, and have expanded their larger leaves over those of their smaller and weaker brethren, thereby excluding them from the privileges of the life-giving sun, and appiropriating those privileges for their own use. Return to the island in after years, and you will find that where originally hundreds of thousands of juvenile sycamore trees were to be found, there are now left only scores of giants, in complete possession, the weaker ones having been ruthlessly destroyed in their infancy by the arboreal Herods you see before you. Every laughing 
meadow, even, is crowded with tragedies of plant-life. We forgive the survivors, if, indeed, we think of what has occurred, because we accept the entire absence of a moral nature in vegetal life. But on the other hand we also find in vegetal life some of the altruistic family virtues accompanying the selfish and egoistic virtues, of which the care of offspring and the struggle to secure family survival, even at the expense of vitality, as in the higher forms of life, is to be noted as forming an important parallel to duty in human life.

What a wonderful presentation it would be, if we had, arranged before and around us, the seeds and new germs of all vegetal life, so that we could note the ingenious and multitudinous devices by which they have been protected, as if by a wise and tender care during growth and after, and finally distributed in the way most likely to secure survival and the perpetuation of their kind. A high degree of vegetal societary life and action may be found in a field of wheat located on a rich soil. While each individual plant is engaged in the serious business of drawing all possible nourishment from the adjoining soil and in lifting its head as high and as rapidly as its brethren, so as not to be overshadowed by them, each meantime engaged in the important function of reproduction, the whole field seems almost inclined to frolic as the grain waves to and fro in the sunlight and the passing breeze. If the farmer has sown the seeds thickly, each plant secms to understand that its duty is to expend its energies either on one stalk, or stem, or upon a very few of them, the aim of each being to keep at least abreast with all others in growth. If, however, the seed has been sparsely sown, each individual plant seems to take note of the fact, and, particularly where the soil is rich, it stools at the root so as to occupy the space, sending up many stalks and producing many heads full of kernels of wheat, all from the same root originating in a single seed. In either case there is a seeming recognition of associated fellows of its kind and an almost intelligent accommodation of itself to its societary conditions, in this and in other respects. In all such cases of vegetal societary development and prosperity there has been great slanghter of vegetal life by the farmer, who, putting in the plough, has turned over the sod and ruthlessly destroyed the antecedent vegetal life, on the decay of which the wheat builds its own prosperity. 
Again, certainly under artificial conditions, but also in a state of nature, there is extension of protection to weaker brethren - by the shading of those requiring shade, and otherwise. Wishing to have a meadow occupied by perennial grasses exclusively, the farmer sows his timothy, clover, or other seed, with the wheat or other grain-seed; whereupon the more hardy and rank-growing grain-stalks shade from the killing sun of summer the tender spronts of timothy and clover, until - the grain being cut in the late summer, or early fall — they spring forward rapidly, and, before other plants, or weeds, can make head, timothy or clover is in possession, not to be ousted for a term of years. Substantially the same action is seen to be taken naturally, without the intervention of man, - as where the shade of forest trees permits and protects the growth of humbler specimens of plant-life beneath their branches.

But, practically, the whole of the lower plane of individual and associated vegetal life is subordinated to the higher forms of life found in animals, and to their needs and uses. While the capacities of choice and of change in place may here and there be hinted at, or suggested, in vegetal life, it is not until we reach the level of animal life that we find these as predominant characteristics - disregarding certain low forms located near the line of transition from the vegetal to the animal type. With these capacities we find associated more or less rudimentary forms of mind, and capacity for expression, intercommunication and language, together with dominant selfishness, which in the world of society occupies the place and fills the functions of the law of gravity in the material world, and out of which all order eventually develops.

In animal life, associated action among individuals of the same species tends to increase, in general, as carnivorous tendencies diminish; perhaps we might say, it is caused by them, where the weaker ones combine for protection against the stronger, - until we reach such animals as the sheep, highly peaceful in their nature, living together in Hocks, and attracting attention as such, as types for the consideration of human beings in their moral, societary, and even religious relations.

Having come into being under the same laws and administration as mankind, it is naturally to be expected that prosperity and well-being among men will be accompanied 
by prosperity and well-being in contemporaneous and associated individual and societary vegetal and brute-animal life; and experience confirms the expectation, as well as the converse proposition.

In this connection, it is interesting to observe the difference between the wisdom of the early writer or writers of the account of creation already referred to, and the modern interpreters of it. Thorns and thistles are the direct result of imperfect vegetal development; and they are evidently recognized by the former as related to human degradation, and to the evil that degradation produces, even in its effects upon the ground on which the "fallen" man treads. And to one who has noted how serpents disappear before an advancing society, and how they reappear in the track of a declining society, the connection of the "fall of man" with the serpent seems by no means entirely fanciful.

Everywhere, among all forms of life, associated action among individuals of the same species, seems to have for its initial motive the principle and function of sex and the contmuation of the species, with protection and safety as a near object, extending later on into various lines and methods of improvement, or progress toward an ideal perfection, accompanied from stage to stage, or in gradation, by a tendency toward diminished reproductive energy, as protection from enemies and prolongation of life are obtained. In vegetal life the full blown rose may be taken as a sample of that perfection; the perfection consisting in a gradual elimination of the reproductive organs and functions by their substitution or translation into the beautiful petaliferous forms that compose its glory. In this stage the reproductive function is wanting, and the life of the same individual plant is continued and multiplied by the slipping process, instituted by the gardener.

It may be said, in passing, that a similar course or stage in the development of human life would be represented by an approach toward a condition of individual immortality, the ultimate condition being one in which the reproductive function would not only be wanting, but would be unnecessary, and in which all the highest possibilities of the human mind and soul would be in the most perfect state of efflorescence, and when man would have become a fit companion for the Angels.

While there may be no immediate call for alarm lest this 
stage should be speedily reached, it may be admitted that the conception has for ages made occasional visits to the human mind, and is at the present time engaging the attention of speculative thinkers and writers, who, following substantially the leadings of physiology, intimate that all we have to do, in order to secure immortality here on earth, is to learn how to perfect the forces and processes of absorption and assimilation in the human body, so that they shall be equal, and that none of the chemical elements composing the body shall secure permanent lodgment, as occur's in the hardened muscles, ligaments, tissues and brittle bones of old age; whereupon it is claimed that the vital force will be competent to run the machinery of life forever, in perennial youth.

Whatever the ultimate truth may be in this regard, in all the earlier stages or ranks of life the reproductive tendency is necessarily great, and evidently so for the purpose of supplying the waste of life that inevitably occurs, thus preventing the extinction of species; and, in the later and higher, the reproductive tendency usually diminishes in some proportion to the diminished need, as life becomes more safe and mental action with its opportunities is normally increased.

It may be said, here as well as anywhere, that the supreme question in all societary evolution is this question of the rate of reproduction. In vegetal life, especially, and in brute-animal life as well, in the main, increase in the rate and ratio of reproduction is in the line of progress and development - certainly so in their earlier stages - since the needs of man are thereby the better and more surely supplied; as well as waste, and seed and germ necessities for continued future use.

In human life a high degree of reproductive activity is necessitated by the destructions and wastes of war, disease, poverty, ignorance, crime, and other like causes of death and removal, and by and through the inherent workings of associated conditions accompanying them. But the associated conditions of peace, health, suitable prosperity, intelligence, and obedience to the laws of life and society, through the natural and necessary workings of associated physical and other conditions, result in a diminishing rate and ratio of reproduction, and, co-ordinately, in increased intellectual development, in relief in the strug- 
gle for existence, and in a higher order of societary life.

In view of the fact that the functional activities of sex have these important relations to society and its evolution, the methods of sexual association at once appear to have supreme importance not only, but we may instantly more than suspect that the laws of that association have been deeply laid in the very foundations of things. As to marriage, and the method of thereby instituting the human family, for more than one reason the public discussion of the subject, like the happy state itself, is to be entered upon with great care and deliberation. The thorough and public scientific treatment of it certainly may not now be either wise or convenient, but the importance of the general subject of sex relations compels thought and consideration.

It may therefore, with all necessary boldness, be said, that stock-farm principles do not apply among men,-for one reason, that an exceedingly fine appearing physical constitution may be accompanied by a moral or a mental nature so defective as to more than neutralize the physical advanitages, as compared with a less perfect physical, combined with a more perfect moral or intellectual nature. Inleed, stock-farm practice is beginning to be influenced by (jualities of character, spirit, docility, courage, and obedience, in the selection of breeding animals. And Evolution, if it teaches anything, teaches everywhere that, living according to the true laws of life, a practically perfect race may be developed from, and as descendants of, individuals of the lowest order, provided that the higher laws of life are even approximately obeyed from generation to generation.

We were formerly told that only the strong should marry, and that the not strong should not marry. But we have now practically arrived at a stage where we may say that depends. It should, however, be said, that no society that discourages marriage and makes it difficult for those to marry who desire to do so, is good society. And the same should also be said of that society into which the entrance of a child, or any number of children, is considered an intrusion. Evolution at least has no uncertain word to say on that subject. In vegetal life, polygamous and pretty nearly every other form of married life prevails, and yet we hear nothing of marital outbreaks in that direction, and no 
discussions whatever as to whether marriage is a failure. If there is marital misery in vegetal social life, the victims discreetly keep it to themselves, and do not let it get into the newspapers.

Among animals there is, upwardly, a decicled tendency to pairing. Birds are recognized as belonging to a very high order of life, and they usually not only pair, but have their own personal preferences as to individuals with which they prefer to pair, with obstinate little wills of their own behind them. To one tired of studying the confusions of human society and almost on the sharp edge of despair, the opportunity to watch a pair of canary birds, or many pairs associated together, furnishes a source of comfort, if not hope. Without the aid of lawyers, doctors, ministers, or even Ethical Associations, to teach them the way in which they should go, you shall see the duties of their little lives promptly and cheerfully performed, the burdens of maternity not beyond their strength, and giving no indication of inherited curse, their beautiful progeny inheriting the physical and mental qualities of their parents, and many other evidences of law and order working constantly upward, unless they are in some way unwisely interfered with by man.

In whatever way, then, this branch of the subject may be studied, when thoroughly studied the conclusion reached must be that certainly nature has made no mistake in establishing the principle of sex; but we may sometimes be led to think that, in the management of it, "only man is vile."

As to early associated life among human beings, the physical and psychological structure of living men and races, studied in the lights of the laws of heredity, inevitably imply conditions and relations analogous to or identical with those to be found among higher animals; while archæology cliscloses to us the early homes of men and families in caves, the rude working-tools, weapons and other implements they actually used, and many of their ways of life; and the various stages of development, linked with that of historic times, confirms the original low or rudimentary state of men individually, and in their societary relations.

In this day and age, thanks to Evolution, it is hardly necessary to frame any argument to show that men were not originally placed on this earth in a state of perfection 
from which they lapsed. But we may still allude to the claims to that effect, handed down to and recently dominant among us, as interesting and as tending to confirm the teaching of Evolution, if it be considered as in the nature of aspiration, the expressed hope of a condition yet to be realized.

We have seen that the initial force, out of which order was to come, was a centripetal one, and apparently directly antagonistic to that order - but that, at the very beginning, as we recognize it, a principle was established at the very core of things, by and through which balance of forces and harmony of motion were the result of tendencies that seemed to necessarily destroy them. The study of society discloses another instance of the same kind, and the principle runs through vegetal and animal life. Nothing could well be more selfish and centripetal than the original sexual impulse. Yet, initiating the family, it becomes the creator of society through the development of the altruistic or centrifugal tendencies, whose origin may be traced directly to it.

At the beginning of historic times the family was already in a comparatively advanced stage. Co-ordinately with human development everywhere, according to archæological and historical evidences, a development of religious ideas has taken place. Indeed, societary development seems to have been largely dependent on religious development, if not governed thereby. The whole family life of the ancients, their society, and eventually the State itself, as it took shape among them, grew and developed around their domestic gods, and were limited thereby. They worshiped the manes, or shades of their fathers, as we worship a FatherGod. Their ideas of creation did not go back of generation. The fathers were to them their creators, because through and by them alone, as they understood it, came the spark of life. The tombs of the fathers were located near the house, to give access for frequent worship. Their gods were therefore ever present to the ancients, and had to do with all their acts as they went out and came in. Annual religious banquets, or feasts, were held in worship of these manes, the eldest son being the high-priest, and the wife, daughters and other women of the house being only competent to worship through him as such. The manes of their dead ancestors were, we are told, supposed to say, 
"May there be successively born of our line sons who, in all coming time, may offer us rice boiled in milk, honer, and clarified butter." Negligence of the son's duty to make these libations and sacrifices was not only the grossest possible act of impiety, but was nothing less than the crime of parricide, multiplied as many times as there were ancestors in the family. So long as these attentions were contimed the ancestors were the protecting gods of the family. providing for them, driving away and inflicting diseases upon all those who approached who had not descended lineally from them. Marriage among the Greeks and Romans was controlled by the same principles; the continuity of the family, - survival, - was the subject of most jealous care; adultery was most impious, as it might taint their very god-head; celibacy was forbidden; divorce for sterility was enforced; the women of the family were made subordinate; the rights of property were fixed exclusively in the head of the family; the right of succession and inheritance was controlled, and almost every act of life was regulated by this system. Their gods guarded the boundaries of the landed property of the family, and, later, of the tribe and city or State, with exceedingly jealous care, as they supposed.

Every house had its altar and altar-fire, renewed once every year, and carefully kept meantime, and was the source of moral order in the family state. This altar-fire was concealed from outsiders, as were also the ceremonies, the creeds, the chants, the hymns and the prayers, which were transmitted only from the father-priest to the son destined to be the priest when the father had become one of the family gods. Justice for the wife, the sons, daughters and retainers rested in the house, and in no external city or State, in the beginning; the father as judge might take away the life of any member of the family, - wife, son, danghter or other. Strange as it may seem to us, this system developed great strength and endurance, and a high order of society.

Sir Henry Maine defines the controlling characteristic of Ancient Society, thus founded, by the word Status; and the Modern Society, or the society that took its place, as being founded on Contract; the former being a natural state or condition, and the latter - in which we are now living being reached by consicleration, examination and discussion, resulting in agreement or contract. 
When we were engaged in considering planetary evolntion, we found that the planets were located and swung in their orbits by the combination of two balanced opposing forces, one centripetal, the other centrifugal. Out of these opposing forces not only have the harmonies we have observed in the heavens grown, but eventually, in some sense, our own being and those elements and forces that are concerned in and control social action. An excess of either centripetal or centrifugal force in the planetary system would destroy harmony, and bring, or inaugurate, ruin.

Similarly, societary harmony grows out of balanced egoistic and altruistic moral forces; and want of harmony grows out of an unbalanced relation of these forces.

Status, then, being practically founded upon natural affection, the family state was a strong state, and built up and maintained a strong form of society, so long as these two forces permeated the State in balanced relations. But, as population increased, the family was found to be incapable of taking all individuals into its relations. Therefore the tribe was formed, on the family plan or principle, but extended, with simulated fathers, not actual fathers governed by natural affection, at its head. After the tribe came the curia, and then the city, formed on a similar plan, but the fathers at the head of each being at each stage so much further removed from the natural father and his balanced egoism and altruism.

A society so constructed was sure to break down eventually, because the natural altruistic or sympathetic force could not extend indefinitely, or much beyond the reach of the natural father,- whereupon the necessary balance of order would be destroyed, and injustice must prevail, with societary disorder and ruin certain to follow. And that was exactly what occurred in States so organized. Status Society broke down, and a mere makeshift - Contract Society - took its place and has since held it, among so-called Christian nations.

But Evolution teaches that Contract Society is not the final and perfect society, and that it is, through the defects of the human understanding, in a sense the real cause of our present society troubles. Contract Society is the result of a laudable attempt to find, by the aid of the trammeled human understanding and imperfect discussion, a ruler for the world who would and could conduct its affairs on family 
principles and status, but which attempt failed at an early day, and has never since been renewed with any prospect of success until now. Indeed, however desirable, it cannot be successfully accomplished until not only the "hells" are converted into "benefit," but the devils themselves are converted into saints. These are precisely the mndertakings that Evolution proposes, - admitting, however, that their accomplishment is work for the ages.

The wisdom of the ancients was not equal to it, because, to them, nature and nature's life-giving Creator seemed, everywhere, at all times, to inextricably mingle malignity with kindness, not showing natural affection for his children in the State; and therefore they compromised by accepting poor human justice established in Contract, instead of the permanent Divine Justice established by the God of the Universe, which they sought in vain to find.

If Evolution has not already discovered how and what this justice is, and how it works, it at least points ont the direction in which the promised land lies, and therefore the future hope of mankind in society seems to rest in its hands. Evolution places millennial conditions upon a scientific basis, and thereby makes them practically possible, taking them out of the domain of dreams and the visions of seers. It may therefore justly be called the gospel of good-will to mankind as declared by Science-since fatherly beneficence is its key-note in contemplating and setting forth the character of the Infinite Ruler of the universe. Perhaps the most important work of Evolution is the bringing of human knowledge and achievement to the assistance of the Divine law and purpose, and directing them as one force for the development and welfare of human society.

Misleading bias of many kinds has already been mentioned. Doubtless it interferes in all liuman affairs, but probably to a greater extent in the consideration and treatment of matters directly relating to society than elsewhere. Yet when bias is rectified or counterbalanced, errors of method still appear in the study and practical management of society. Mechanical principles and analogies furnish partial but not complete solutions. Evolution, in addition, brings to our aid the prineiples and analogies of organic life, by treating society itself as an organism, or at least as super-organic in its nature.

Paramount importance is given to Biology, as a prepara- 
tion for and as a constant accompaniment of the study of Sociology, under the guidance of the evolutionary philosophy, not simply because Biology only can explain and enable us to understand the units that in association make up the aggregate called. Society; but also because biological principles seem to be in many cases the only principles by which society as a whole can be reduced to a system and understood. Treating society as a growth, or organism, Evolution undertakes to explain what has otherwise been considered inexplicable, as not reduceable to any system of change, increase or diminishment, largely because of the supposed omnipotence and certain divergences of the human will in action. Evolution recognizes that the individual will has for its domain only an area in many respects narrow, and in all respects bounded by well defined limits. And it recognizes further, that both individual men and all societies made up of them, live and move and have their being within a surrounding envelope or environment having many of the qualities of a mechanical matrix, or mould, - especially those qualities which act as barriers to resist the flow of the freest and most molten human purpose,and also some of the powers of a living womb capable of producing organic life.

At the very threshold, Evolution asks: What is Society? And answers, that it is a living organism, or super-organism, and not a mere mechanical aggregation; a lasting, and not a temporary arrangement; capable of maintenance for generations and centuries as an organized whole, while many times over the individual units composing it have been born and died out of it, without disintegration or substantial change of the whole.*

Evolution finds no difficulty in holding, on self-evident grounds, that society is not an inorganic structure,-_-seeing, for one thing, that it is composed of living units. That society, however, is an organism, composed of parts having permanent relations analogous to those existing among the parts of a living body, does not at once appear to the student. Some inorganic aggregates, as crystals, seem to grow ; but living bodies and societies exhibit increase of bulk, alike, until they are overwhelmed or deprived of the necessary elements of growth. Alike, living bodies and societies, while increasing in bulk, from the beginning of the embry-

* Principles of Sociology, Vol. I., Part II., Chap. II. 
onic period multiply and simultaneously differentiate their parts. In the newer parts of our own country we yearly see socreties begin in homogeneous conditions, and rapidly become transformed into fully organized structures with all the organs and functions of the most advanced societies. Not being compelled to take all the steps of growth for. themselves, and being privileged to borrow from others, they sometimes grow with a speed that suggests mere aggregation; still the relations of their associated parts, on examination, are found to be those of the vital order. Then, in living bodies and in society, alike, with increase of bulk, comes progressive differentiation of connected, mutually dependent functions, resulting in a physiological division of labor in both cases, through developed organs adapted and specialized so as to accomplish a higher grade of work, thereby increasing the powers and raising the grade of the whole.

Much of the difficulty of conceiving of society as an organism arises from the fact that it is evident to the senses that society is composed of indivicual units having a life of their own, but with no apparent connecting tissue by which they are related to the other units composing society. We are therefore compelled to look deeper into the organization of living bodies; and when we do so, by the aid of modern Biology and modern instruments, we find that they also are built up out of cell-units; that the differentiation of organs and functions in them is dependent on and accompanied by the vital plasticity of these cell-units, or, in other words, on a change of function similar in many respects to that which takes place in and among the individual units of society; and that each cell of the animal body has still more or less of independent, individual life on which depend many of those characteristics that distinguish organic from inorganic bodies, - as capacity to unite again after being cut or separated by violence, to generate new cells, to repair injured tissue; and even to transfer tissue from one part of an animal to another part of the same animal; and also to transfer it from one animal to another animal - amounting to an emigration of cells from one country and allegiance, and naturalization in another and distinct country. We find, in fact, that living bodies are in reality communities of living cells, still in possession of many of the powers of independent cells, but contributing 
to and aicling to form a new societary unit out of the combination of such unit-cells. So, too, as in society the units may not be in perfect unity and under perfect control of society, in living bodies there are different degrees of unity with the body of which they are a part, some having more individual power, some less.

The apparent want of motion in most of the cells making up living bodies, hinders appreciation of the independent cell-life. But in the higher organisms there are to be found increasing numbers of cells having very free motion within limits, each with independent "life-histories," - as the blood corpuscles, which pass from infancy to adult life, and thence to old age, having each a career as complete in itself, in some respects, as any living thing, and all within the body of the animal, the life not being in any sense parasitic, but an elemental life, normal, necessary, and in entire harmony with the larger life of which it is, or creates, an essential part.

If time permitted, many other evidences might be produced to show that "an ordinary living organism may be regarded as a nation of units that live individually and have many of them considerable degrees of independence"; and, on further noting in how many human units of the societary organism the individual life is limited and controlled by the societary life to which they belong, we shall perceive that when a nation of human beings is regarded as an organism, the analogy is by no means a forced one. In both cases the units, or some of them, may live after the aggregate has been destroyed, and, when undisturbed, the aggregate lives, although the units die and pass away after having performed their proper functions in full to be succeeded by new generations of unit-citizens, for periods more or less indefinite.

Further, it is found that no view of society is complete that does not take into consideration forms of life still lower than men, - as brute-animal and vegetal, - each of which constitutes an essential part of the societary organism, and is found to correspond with essential parts and growth found in all animal organisms, and forming distinct classes of analogy.

Among living organisms, as we ordinarily apprehend them, the seemingly essential feature is what may be called the cohering unity, or continuity of structure, not so ap- 
parent in society. But on looking into the organization of living bodies more thoroughly, it is found that such continuity is not alone sufficient, but must be accompanied by capacities of intercommunication and control throughout, which, being seriously impaired, though continuity may remain, death and disintegration begin. An essential part of srowth is this increase of capacity for intercommunication and control; and when it begins to fail, as in paralysis or gangrene, the organism begins straightway to lose its characteristics as such. In the social aggregate a similar state of things is found to exist - establishing a mutual dependence of parts which constitutes organization.

Nor is this conception of society as an organism so new and strange as it may seem to be. For many generations. past, in the domain of law, it has been customary to treat aggregates of men, some known as private and others as public corporations, as artificial persons, to be held responsible to natural persons, to the State, and to other like artificial persons, as natural persons are held, and having other powers and duties of natural persons. This has come about, apparently, because it was found impossible to deal with them on any other principle than that which assumed that they had the characteristics, qualities and powers of real persons. The artificial part of these corporate persons has. been furnished either by the legislative branch of the State, or the autocratic power of the king; but, nevertheless, characteristics of independent organic structure of high order are also to be found, among the most important of which is continuity of life beyond the ordinary periods of human life.

In the Spencerian argument for the organic nature of society, there seems, however, to be one very essential but missing link. "Society," he says, "exists for the benefit of its members, not its members for the benefit of the society," there being no Social Sensorium, Consciousness not being concentrated in a small part of the aggregate, but being diffused throughout the aggregate, and all the units. of society possessing the capacity for happiness and misery in equal or at least approximate degrees; - whereas, in the individual organism, consciousness is concentrated in a small part of the aggregate, - the nervous system,- to which the assets of happiness and misery especially belong. And he holds that this difference between the individual 
and the societary organism must fundamentally affect our idea of the ends to be secured by social life. He admits, however, that men, as units of society, differ to an appreciable extent in capacity for sensation and emotion, as do the units of individual organisms; and it would not be difficult to show that in other respects there are corresponding differences. In the one, many of the cells or units act automatically, and, in the other, probably the larger part of the individual units act without the incentive of individual thought and volition, to a large extent.

Before the days of Evolution, the prevailing view was that society was the result of a process, proceeding, or combination of processes or proceedings, in the nature of institution. And many of the observed phenomena accompanying the formation of different societies do suggest a method analogous to instituting or building rather than developing or growing. But it is to be noted that while building is noisy work, and therefore attracts attention, growth is noiseless in its methods, and for that reason some of its greatest results have had less attention than they deserve. Therefore it is that so much of the history of the world must be rewritten.

On looking more clearly into society, it is seen that enlargement is always accompanied by changes that follow and resemble those of growth in individual organisms, as stated in terms of the evolution philosophy and fact. And when evolutionary growth has done its work, examination discloses organic characteristics in social organs, structures and functions, to all of which Mr. Spencer applies the term or title of Super-organic, to distinguish it from the lower or individual organic form.

Being an organism, society is not only capable of growth, but of decrease of vitality as well as increase, of disease as well as of health, and finally of death and decay as well as of life and growth. Certainly all will admit that, like the woman of the bible, society has suffered much from many physicians, and seems destined to continue to be afflicted in that way - in fact, never more than at the present time.

The experience of Mr. Spencer teaches that a word of caution is required in treating society as an organism. The analogy must not be carried too far or applied too closely. Its values lie in "the mutual. dependence of parts which they (the body politic and a living body) display in com- 
mon," in their structural and functional comparison, in "community in the fundamental principles of organization," and in the co-operative action of the parts in the whole.*

Mr. Spencer and his followers apply organie prineiples in the study of all the multitudinous customs and ceremonies of different soeieties, the world over,_-and likewise in the study of all political forms, structures aurl instrunents, all military, judicial, exeeutive, legal, property, revrme and industrial systems. Even fashions, dress and personal adornment are not too sacred subjects for the prying and spying eyes of these philosophers, who undertake by the airl of evolution to explain the origin and history of the whims of the fairer part of creation in these particilars. And yet lumnan society, or our branch of it, seems to be at this late day and age in a state of almost inexplicable: disorder, or at least withont any common consensus as to the direction of finture progress or as to the necessary ste 1 s to secure it.

Surveying the vegetal and brute-animal worlds, these: two forms of society seem to have rlone their work well, since all the wealth of benefit we have therein is due to what it is no misuse of words to call their societary action. Primitive and prehistoric man also seems to have done lis work well, since to him we owe the donestic animals and rearly all the forms of improved vegetal growth, as well as the inprovert stock of his race handed flown to us from wild, savage and brute progenitors. 'T'he nen of the early' historic period are also entitled to, and do receive, our connmenclations for what they rightly did in their days and generations - for to then we moderns yet turn when the storm and stress of life are heaviest upon us and we cry out for consolation and hope.

During soniething over two thousand years past, however, a sort of blight secms to have come over and resterl "lpon the most advanced societies of the world, - relaxerl, to be sure, during the past four hundred years, more or less, and still relaxing, but whether permanently so remains to be seen. The older societies have with slight exception remained during these two thousand years in a state of stagnation, and need not here be considered.

One of the earliest and most important duties the crolu- 
tion philosophy has to perform is to explain to us the cause or causes of this apparent check in human progress among the most advaneed peoples. The primary question that arises in this connection is: Whether those who have been of what we consider the highest and best form of human soeiety, have been deprived of any portion of their neeessary equipment for their work during that two thousand years?

Aceording to Evolution the most important part of the animal organism is the sensorium. Little or no animal ovolution could have taken place without its aid. Mr. Spen"'re says society has no sensorium, and it would seem that we need search no further to find the cause of arrested sorietary evolution.

The human intellect is, according to Evolution, the crowning human possession. Something more than two thousand yeurs ago, among the Greeks, it reached, so far as we know, its highest elevation, but subsequently lost its position, and has not yet regained it. During most of that periorl, in the civilization to which we belong, the intellect has been under' a ban, and in discredit. 'The power that declared and has enforced that ban is the so-called Christian Church.

Evolution has cheerfully submitted to the most searching criticism, doubtless with great benefit; and in view of the alvantage secured to those who would remove the motes f'rom the eyes of others by submitting to the removal of the beams from their own eyes, the defenders of the Christian church ought to welcome like criticism.

The substantial harmony of Revelation and Science, as explained by Evolution, has been already suggested. 'There is too little space left in which to marshal the features in which this harmony is found. Both imply one God, or one Supreme P'ower from whom all things proceed, to whom all obedience is due, with eternal life, aeonic life, life from age to age, survival, and the inheritance of the earth, as the common reward, return, or consequence of that obedience.

The account we have of Creation, as an early statement of the origin of things, might be directly and logically implied by Evolution as necessary and inevitable, in view of the primitive conditions of the human understanding. Evolution finds some of its own fundamental principles of society anticipated in the Decalogue; in the Jewish ceremonial law as the necessary means of ('ontrol for' a stiff-neeked 
people; and, in the existing Jew, finds a wonderful example of the application of its principles, as well as of the fidelity of the Supreme Power to the "Covenants" said to have been made with the fathers of his race. The history of the Jews confirms Evolution in its view of the family and the care and culture of the young; of the primary importance of the selfish or egoistic principle as the law of life; and of the duty, with all other getting, of getting understanding. By careful study of the imperfect record, Evolution finds, or must find, in the teachings of the Founder of Christianity, the method by which the "law and the prophets" are to be fulfilled, and not destroyed; and this on evolutionary principles, through the practice of universal justice or righteousness, resulting in the relaxation of the struggle for bread and clothing, and in the inheritance of the earth by the meek instead of the violent. And it may be saicl that the interests of evolutionary sociology are profoundly concerned in the underlying philosophy of the transition from the Jewish system to a system of universal application — to the Jew and Gentile _ as embodied in the words of the Master, which have been handed down to us ; since it seems to bear upon the question of a sensorium for the societary organism, without which it must find itself classed among the blind, groping, worm-like and acephalic organisms of the world. Even those who have been repelled and disgusted by practical Christianity must admit that the original record. in so far as it discloses a plan and a purpose of teaching Life, and so far as it does teach the truth about it, is in harmony with Evolution.

As herein considered, society in its complete sense is. life writ large, and includes all life - associated vegetal. brute-animal, and human. And in a certain sense it is one organism as such, since through the laws pervading life as a whole, like so many nerves, no part of it can be injureil or benefited without affecting to some extent - however infinitesimal — all other parts. Instance, our recent Rebellion. which came so near to reaching our Societary Sensorium and destroying the Union. It derived its initial force from the treatment of the cotton-plant and the soil on which it grew. The primary injustice was to both these factors, the secondary to the labor concerned, and eventually the life of the Nation itself was imperiled. Impoverishment of the soil defraurled the nlant-life first, and all other life- 
after it in turn, resulting in a low condition of the entire Southern part of our social organism, that finally became unendurable, and produced the social disturbance of which we were witnesses. Numerous examples known to all, where justice to plant-life has resulted in individual and national prosperity, well-being, and development, require no mention. 'The sensory apparatus of society may not yet recognize these relations and the dependence of the higher upon the lower life as parts of the same organism, because of its present imperfections; but the approximate proof of them is not a matter of difficulty; and Evolution not only implies them, but it also implies present or eventual capacity on the part of the human mind and of society to have knowledge of them, and to base action upon that knowledge. Only by and through such knowledge can our Contract Society ever be translated into that State which may be called Divine Status, or a status in harmony with all the laws of Life, of which the Family-Status Society, as defined by Maine, was but the miniature and prototype.

In mere mechanical aggregation, in which individual cells are added or annexed to other like cells, there is no relation between them that permits differentiation and growth, and no sensory organ or function either in the individual cells, or in the aggregate. But in organic aggregation these must. be present, and must have free play, or proper, normal growth and development cannot take place.

The principle applies with augmented force in the social organism, and requires free play, especially for the individual human mind as the.primary and type of the societary mind.

According to the evidence we have, the historical Christ, when dealing with the "kingdom of heaven" - which he said was at hand - as embracing his societary scheme for the relief and salvation of humanity, employs a single word as embodying the necessary condition precedent of such a scheme, which embraces this principle and endorses it with all his high authority.

The custodians of the record have concealed this fact, by falsely translating the word so used,-making it to read, "repent," and using it so as to require "repentance" as the necessary and effective preparation for the new Society. The words so translated are, in the original, meta-noeo and met $t$ noia. They relate, in reality, to mind and knowledge. and 
to that exercise of the mind and of that knowledge which is beyond (meta),- beyond mere sense perception and all concerns of Life, Society, and whatever relates thereto, looked at as truth from the point of view of the Supreme Power of which they are the product.

This mistranslation began as early as the Latin Vulgate, and has continued down to this hour, protected with such care by suborned dictionaries, and otherwise, that although we have in the English language the cognate words, prognostic, diagnostic, agnostic, it is still wanting in the words metagnostic and metagnosticism,-although they are of such supreme importance in relation to the coming of the Kingdom of Heaven and the new and better society in which humanity has been promised relief from the grievous burdens of dominant imperfect Society.

Meta-noetics being, then, for these reasons in part, as yet an unborn science - unless it be concealed in Evolution as its swaddling-clothes - we are hardly yet prepared to search for the Social Sensorium, but must wait for its development until the association of free-acting individual minds has integrated the new organism in some recognizable form.

If these positions are sound, the backward state of Modern Society, and the many afflictions it endures, are traceable to the Christian Church and its priesthood, who have been guilty of this falsification, and have hindered the normal development of that new society which it was their duty to help.

Owing to what I believe is an unfortunate misunderstanding, the evolution philosophy has also become associated with important limitations of the human understanding, and evolutionists have acquired, or assumed, the title of Agnostics. Whatever may be the exigencies of strict philosophy and truth in defining the limits of the knowable, Evolution teaches that there are yet reserved possibilities in the human race and inind. The physiologist and chemist can now handle, weigh and analyze the material elements out of which further intellectual evolution may come, and it would seem too early to fix its absolute limits now. Certainly so far as the arena of societary evolution is concerned, the intellect should have full scope, and philosophers should not unite with priests in keeping it imprisoned.

In their days of decline, the Greeks of Athens erected an altar to the "Agnostic God." Paul, seeing that altar, 
preached to them a sermon on Mars Hill, in which he sought to check their superstition by presenting to them his Meta-gnostic God as the Christian substitute for their Agnostic deity. In the preaching and teaching of Christ himself, meta-gnosticism is everywhere associated with the coming of the kingdom of heaven, as a necessary preparation therefor, and the pivotal turning-point of its inauguration.

No advance in knowledge can be made unless the human mind penetrates beyond the phenomena presented by the senses. So far the brutes themselves may go. Meta-noetics relates to this "knowledge beyond," or, literally, beyondknowledge. This beyond-knowledge is the special domain of Evolution - the domain which it is exploiting and is to exploit. The senses tell us that the sun rises in the east. Beyond-knowledge, or meta-noetics, corrects the senses in this instance, as it does, or will do, in all other cases when it is permitted. For those, then, who would study sociological evolution, at least the essayist would substitute the title of Meta-gnostics instead of Agnostics, as more truly and accurately descriptive, and also as tending to bring all of them into harmony with that wonderful Man who, notwithstanding the falsification of his language and thought by those assuming its protection, has yet been such a power in the world for good.

The members of this Association have sometimes been called "godless Spencerians." When it is discovered that Evolution is in harmony with true Christianity, the opportunity may come of raising the question as to who is really "godless" - if it is worth while. However that may be, those who study Sociology by the aid of Evolution, earnestly seeking to know and apply the truth, cannot go far astray. 


\section{ABSTRACT OF THE DISCUSSION.}

\section{Mir. Z. Sidney Sampson:-}

I have listened with interest to the lecture of Mr. Skilton. I hesitate, however, to speak upon such a wide subject as Sociology in the limited time at my disposal. It is interesting to learn from the speaker that we are called "godless Spencerians," for even alonse is better than indifference, and may lead to enlightenment. The early Christians were denounced as Atheists, and it has been the fate of the representatives of each higher and more rational view of the divine nature to be regarded as atheistical. The correction of such misapprehensions may well be left to time and growing intelligence.

The lecturer has presented various practical suggestions and applications of the principles underlying the evolutionary view of the growth of society. Perhaps it may be useful if I attempt to define a little more clearly the terms "integration" and "differentiation," as these terms are applied by Mr. Spencer in describing the process of social evolution. Social integration is the compacting or conclensation of individuals into communities. Social differentiation is the specialization of these communities - the tendeney to classify the different functions of om complex social life, and to allot each to a separate class, profession or trade. Mr. Spencer applies to society the same principle which lie finds dominant throughout the field of biological evolution. The same law which governs the differentiation and integration of protoplasm into the countless forms of animal and vegetable life, applies also to society, he affirms. The loose particles integrate, and form either animal or social organisms, developing such organs as are necessary for the maintenance of the well-being of each. As the biological process is the resultant of the interaction of the organism with the environment, so in social evolution it is an external pressure which compels differentiation, producing government, commerce, religious and educational institutions, diversity in trade and industries - all the manifold functions of the complex life of society. Spencer's argument from analogy, tracing the same law from vegetable to animal, from animal to man, from man to socicty regarded as an organism, is exceedingly ingenious, and secms almost conclusive. 
Mr. JOIN A. 'TAYLOH:-

'There is nothing more pathetic than the contemplation of Herbert Spencer's work, unfinished as it is; and as it will probably remain. "Social Staties," one of his earliest works, is one of the most remarkable books ever written, though very imperfect in the author's eyes. He started with some accepted scientific ideas, which he attempted to apply to the existing social status, and went on from these to his elaborated theory of the social organism -an aggregated humanity. But in many things he has been able only to furnish the outline of a work which must be completed by others. When such a master-mind treats the subject of Sociology with so much diffidence, it is hardly to be expected that we should sound its depths in an evening's discussion. Though Spencer is not to be charged with empiricism, there is evident throughout his work a great yearning to meet the practical wants of humanity. We may all well strive to emulate his spirit in this respect. What I most admire in Mr. Spencer is the courage with which he attacks the errors and abuses of our conventional life and thought. To uplift the race, we must not only be willing to study methods, but we must have the courage of our matured convictions in the application of the results of our studies to the affairs of life. We are justified in cherishing a noble discontent in regard to present imperfect social conditions, but we must also wisely strive for their betterment. And we must be patient in looking for results. All remember Spencer's words in the closing chapter of his "Study of Sociology," to the effect that students must not be discouraged by the lapse of time before society becomes perfect. So long as we are working in the right direction, we may well be hopeful for the future.

\section{Mr. HeNry S. BELlows:-}

It seems to me that this question has been treated too much from the outside - that too much stress has been placed upon the influence of environment. There has been too littleconsideration of the inner forces - the forces of innate character and organization, in the development of society. I think outside pressure is not the cause of social aggregation, but that this is the result of a law of association which is not the product of external pressure. Out of this law of association, which is a part of the nature of individual man, the necessity of government arises.

Mr. William Hanson:-

Mr. Hanson, at the President's suggestion, gave a brief account of a society in Atlanta, Georgia, of which he was a member, which 
has taken up and is now pursuing the study of Spencer's "First Principles." Continuing, he said: The principle involved in securing that balance of egoistic and altruistic forces which constitutes social equilibrium is the principle of justice. Spencer, in liis "Social Statics," makes a grand endeavor to elucidate this principle. The egoistic foree is now in the ascendant in society, but with the growth of altruism we shall become desirous of spending ourselves in benevolent effort even beyond the requirements of justice. When this is done, social misery will disappear.

\section{Dr. Lewis G. JANes:-}

Mr. Skilton has given us an eminently suggestive paper. To follow out all the lines of thought indicated would involve much time and study. Instead of commenting on any of them, I will endeavor to supplement them in a single particular. I think no one has referred to Mr. Spencer's position as to the temporary nature of all governmental forms. The end of life, the purpose of all social organizations, in his view, is the perfection of the individual; not, as the socialists would have it, the perfection of society under a government of force. Note the bearing of this conception on the social theories of om own time. In all our civilized communities, we have to meet the theories of the socialist on the one hand, and of the anarchist on the other: - the one aiming at the complete subordination of the individual to society, the other at the abolition of all governmental control. The evolution philosophy, as applied to society, should enable us to choose a wise middle path between these extremes; to avoid the anarehistic error of seeking the reformation of social abuses by revolution and the resolution of society into its individual elements, seeing that society can be no better than the individuals of which it is composed;- and to avoid also the equally serious error of obliterating individuality in a homogeneous, paternally-governed, or communistic form of social organization. We should recognize the present utility of government in securing justice, while we insist that its forms shall be yielding, plastic, readily receptive of improvement, adapting themselves easily to the needs of the hour, and tending always toward individual perfection and ultimate emancipation from external and artificial restraints. 


\section{EVOLUTION OF THEOLOGY}

BY

\%. SIDNEY SAMPSON. 


\section{COLLATERAL READINGS SUGGESTED}

IN CONNECTION WITH ESSAY $\mathrm{X}$.

Spencer's Sociology and Recent Discussions; Coulange's Ancient City ; Maine's Ancient Law, and Early Law and Customs ; Tylor's Primitive Culture; Thompson's Religious Sentiments of the Human Mind; Clodd's Childhood of Religions. 


\section{EVOLUTION OF THEOLOGY.*}

The study of the Evolution of Theology,-or, to use the more generic term which corresponds to the precise signification of the word Theology, the Evolution of Theism, or Theistic conceptions,- - presents special difficulties, arising both from the nature of the inquiry, and from the principles in accordance with which it must be conducted. In the investigation of what may be termed Objective Sociology, e. g., the Evolution of Society through the successive phases of patriarchal, tribal and national development, the rise of customs, laws and governments, and of political, industrial and ecclesiastical institutions, we deal with processes which may be observed, and which,- most, if not all of them, - are being exemplified at the present day, in some part of the globe, and in which we are materially assisted by historical, philological and monumental records.

But the subject here under discussion lies wholly within the domain of what we may properly call Subjective Sociology, viz., the origin and development of purely mental conceptions. Such theistic ideas as have heretofore prevailed, or which now prevail, at any given place or period are conditioned and determined exclusively by the mind of that period and locality; a fact which is visible and provable by present observation upon the different phases of theistic belief arising under the varying conditions of savage and civilized existence. Hence the student of this branch of Sociology is compelled to apply psychological principles. A complete explanation of the rise and development of theistic ideas would be a complete exposition, as well, of the Evolution of Mind in general, for it is along these lines that the mental faculty has been primarily exercised and advanced.

We should note, for the purpose of defining the limits of the discussion, that our subject is not the Evolution of Religion, but of Theism only. While it is true that the words Theology and Religion are used, more or less, inter-

\footnotetext{
* Copyright, 1889, by The New Ideal Publishing Co.
} 
changeably, as when we speak of the Religions of the world; yet recent careful writers discriminate clearly between them. Theology is a belief, Religion is an emotion. Questions of Theology or Theism are purely intellectual, and to be resolved, if they are to be resolved at all, through the discipline and exercise of the Speculative Reason. The Religious Sentiment has its outcome and expression in faith, worship, ritual and ceremonial. Our discussion excludes, therefore, all these objective elements, for these have their significance only as exponents of such ideas as may be held concerning the nature and attributes of Deity or deities, as these have appeared from time to time in religious history.*

The Evolutionist, not being able to accept the explanation of the current Theology, as to how mankind have arrived at theistic ideas, - namely, that of an immediate personal revelation, - is obliged, if he would take account of these matters, to endeavor, so far as possible, by the use of what we may call the historical imagination, to realize for himself the mental condition of primeval man, at a period so far removed that we may believe him to have been measurably inferior, in intellectual faculty, to the lowest tribes now existing, as typified by the Fuegian of America, the Bushmen of Africa, or the wandering savages of Australia; and furthermore, in asking the question, How theistic ideas have arisen, he must divest the word "theistic" of any such meaning as is intended by its modern use. Primitive Man, and the lowest races of the present day, did not, and cannot, possess any conception of God or Deity, such as is implied among us by those words. 'To inquire whether they possess it would be as absurd as to ask whether a child of a year old had any understanding of the Philosophy of Kant. It is equally meaningless to ask whether tribes have existed, or now exist, who have no idea of God. As matter of fact no early men or tribes, or lowest races of the present

\footnotetext{
*Want of space prevents our going into the deeply interesting question whether, in the animal kingdom, we discover indications of such mental faculty as may have been subsequently evolved into the distinctively moral and religious ideas possessed by man. Darwin says, "The belief in God has often been advanced as not only the greatest but the most complete of all the distinctions between man and the lower animals. It is, however, impossible to maintain that this belief is innate or instinctive in man. On the other hand, a belief in all-pervading spiritual agencies seems to be universal, and apparently follows from a considerable advance in the reasoning powers of man, and from a still greater advance in his faculties of imagination, curiosity and wonder" (Descent of Man, Vol. II., p. 377). Those who are interested to look farther into the question must consult Dr. Romanes' recent exhaustive treatise on "Mental Evolution in Man."
} 
day, have had or now have it. At the same time, it is believed that none have ever been discovered entirely devoid of a conception of beings superior to themselves, whom they worship, or at least recognize in some form of observance. When the Catholic mission of Dolores was established on the shores of San Francisco Bay, among tribes extremely low in the scale of intelligence, the missionary there placed in charge reported that he found the field wholly unoccupied; for, in the vocabulary of these peoples, there was no word for god, angel or devil. And Spanish historians have alleged that certain of the natives of South America had no inclination to worship anything, high or low, neither from interested motives nor from fear. But in discussing these supposed exceptions, Mr. Spencer agrees with Sir John Lubbock that the existence among them of funeral ceremonies implies some idea, however vague, of ghost and ancestor worship.

It is in the inability of primitive races, and of low types of the present clay, to generalize upon observed facts and phenomena, that we find the explanation of the persistence of a low degree of mentality in large areas, and, at the same time, the clue to the successive gradual enlargement and development of theistic ideas among the nations. 'The savage knows particulars and can deal with isolated appearances, but deduces from these no general conceptions. $\mathrm{He}$ knows his own hut and his own weapon, and the hut and weapon of his neighbor; but to draw from these, or any number of instances of these, the generic idea, hut or weapon, he is wholly incompetent, — and remains incompetent, until, having been brought within the influence of some environment favorable to mental progress, he, at first unconsciously, takes his earliest step in generalization.**

It is just here that the investigator must bring into use the historical imagination. We deal, so customarily and spontaneously, with abstract ideas, our thoughts are fed and nourished in such an atmosphere of philosophical and generalized conceptions, that we fail clearly to recognize that these are the product of ages of inherited mental experience. Our common speech is of laws, rules, causes and effects. principles. But these are, concededly, purely subjective ideas, answering to no single external fact, and merely

Dr. Romanes, in the work before quoted, concludes, after an elaborate discussion of all prior views, that the faculty of induction or generalization, or abstraction, is the essential and controlling difference between man and the brute. 
forms of the understanding. The period which has elapsed since Greek philosophy was given to the world, as compared with the period antecedent to those philosophies, during which, by the siow evolution of the generalizing faculty, they were rendered possible, make Plato and Aristotle writers of but yesterday. And indeed, even when the disciplined mind of the present seeks to catechise the words "law," "principle," they escape all analysis, and we can only say, as the last word, that, like certain inorganic elements, they are undecomposable. Small wonder it is, therefore, if, for uncounted centuries, primitive man should have failed to rise to the point of intellectual advantage required for a mastery of the laws of matter and of mind, seeing that, when once grasped, they are, in their very nature, inexplicable in and of themselves. When, by some fortunate concurrence of favoring circumstances, primitive man first put. this fact with that other fact, and, in a tentative way, began his first experiments in comparison of resemblances and differences, and, in a rude fashion, to select, classify and arrange, under the inspiration of some vague conception of an all-comprehensive law, the future of knowledge was secure, Science was made possible, the Universe was to become revealed as Mind, Order and Beauty; and the Iwilight of the Gods of fear, malice, mischief, and superstition, if to be long delayed, had been irrevocably decreed.

Applying now what we have observed above as to the mental attitude of primeval races to the question immediately under discussion, it follows that they recognize gods, but not God; powers, but no Power. 'They individualize only. The varied phenomena of Nature are forced upon the attention and experience of primitive man in aspects both beneficial and injurious. The latter he makes, intuitively, an object of concern. The beneficent aspects pass mostly unregarded, and are accepted as matters of course. 'That which causes pain, or arouses fear, incites him to the earliest acts of religious devotion, viz., propitiation and sacrifice. All primal religious instincts have their root in the sentiment of fear, which dominates the savage of to-day as well, and centuries of culture and progress have but partially succeeded in replacing it by higher ideals. Primitive man, knowing himself to possess certain mental and bodily powers, involuntarily attributes unusual, or unexpected appearances and changes in objects animate and inanimate 
to an indwelling human personality endowed with powers and activities similar to his own, capable of producing like effects, but by supra-natural forces. He does not recognize plant-spirits or animal-spirits as distinct in their form or mode of operation, i. e., as possessing respectively the form of plant, animal, etc. There is, in each case, the idea of a being, behind the appearances and effects, exhibiting itself as power in action, and controlled by a personal will.

Recently, however, there has been much discussion of the question whether this ascription by early man of personal powers to natural objects is, in the first instance, directly made by him, and an immediate result of the impact of mind upon surrounding phenomena; or whether it is a secondary development, and reached through a prior experience.

The former theory, known generally as the animistic, had been held quite universally until the publication of $\mathrm{Mr}$. Spencer's views on ghost and ancestor worship, which, as seeking to find therein the origin of all theistic and religious conceptions, is, in its general outline and scope, at variance with the animistic view. Personification of natural objects is not, he claims, first in order in the history of theistic ideas. These latter are primarily otherwise derived. Primitive man does not conceive of Mind as distinct from Body. Whatever experiences befall him he does not place to the account of either, to the exclusion of the other. In sleep and dreams he engages in battle and the chase, prepares and partakes of food, exults in victory, and fears approaching danger. Waking, he recalls these vivid experiences, but wakes to find himself lying in the same place where he betook limself to rest. We say that these are merely fancies; the mind has been sporting with illusions, while the body has been quiescent. Our true self has been oblivious to these. Not so, however, does he say. His inevitable conclusion is that some other self than his waking self has, for the while, left the body, taken to itself some other body, - has been journeying, warring, hunting, and, at the moment of return to ordinary consciousness, has resumed its occupation of the body-proper. These visions and experiences are not to him unreal. They are as'real as the familiar objects and pursuits of his waking hours. He truly saw his friend or foe. He entertains no question that his other-self experiences are as genuine as those which affect him in ordinary life. This idea of a duplicate-self, 
which leaves the body and returns to it at pleasure, is intensified by the phenomena of swooning, of apoplexy, catalepsy and other conditions of complete or partial insensibility. All bodily action is suspended until the return to conscious life. What more rational, for him, than to class these facts, observed in others, with those observed in himself, in the case of sleeping and dreaming? In these instances also, the double of the waking self has been absent and has returned; and when, after repeated efforts to recall life to the motionless body, it never again gives evidence of vitality, it must be, he thinks. that the other self has departed to some other region.

Upon these experiences, argues Mr. Spencer, arises the idea of existence elsewhere. These other-world spirits, swarming everywhere, become invested, to the mind of the savage, with exceptional powers over himself for good or evil, mostly the latter. They may possess and control the bodies of the living. Worship for the sake of the propitiation of the ghost is a necessary sequence. Out of the many and varied observances therefrom resulting, come all forms of worship. Adopting mostly Mr. Spencer's words, awe of the ghost makes sacred the sheltering structure of the tomb. This expands into the temple. The tomb itself becomes the altar. The other-world spirit must be fed and supplied with articles for use and service as when here. Hence the universal custom of oblations and offerings to the dead, growing eventually into a formal religious service and ceremonial at the grave of the departed. Abstinence from food in order that he may be sufficiently provided, develops into fasting as a pious practice. Journeys to the tomb with gifts become pilgrimages to the shrine. Praises of the dead and prayers to them become in time embodied in the later elaborate ritual and ceremonial of the temple-service. In proportion to the rank and power of the deceased in his life here, are the degrees of supernatural power and faculty ascribed to him. The ghost becomes a god. The greatest ancestor becomes the god-in-chief. Hence arise all forms and phases of early theistic belief, distinctly originating in ancestorworship. These ideas are not, primarily, projections of the imagination of early man by contact with Nature, but they develop from the conception of the other self, and, when once so acquired, lead to subsequent personifications of natural phenomena. 
Mr. Spencer enforces his argument with a great wealth of illustration. The objection has been made, however, that hotwithstanding the conceded universal prevalence of ancestor-worship, the reasoning, and the facts which are brought to its support, are mainly negative, so far as they are presented in opposition to the theory of animism. The further objection has been made that ancestor-worship implies a degree of fixity in tribal and family relationships which miust be wanting in the case of the earliest races, when hardly yet differentiated from the animal kingdom. That savages of a low type, merely creatures of instinct and emotion, of unregulated imagination, who start at their own shadows, believing them to be, in fact, their mysterious other-selves, should directly ascribe the possession of powers and faculties like their own to objects in motion, seenis possible, and Mr. Spencer himself appears to allow it when he says, "If we set out with the truth that the laws of Nind are the same throughout the animal kingdom, we shall see that from the behavior of animals in presence of unfamiliar phenomena we may obtain some clue to the interpretation which primitive man makes of such phenomena. A brute even of great power and courage betrays alarm in presence of a moving object the like of which it has never seen before. Dread of the unknown appears to be a universal emotion even when the unknown is not at all portentous in character." *

The incoherent and disconnected theologies, if we may so term them, of early races, represent therefore, exactly the loose and discomnected mental ideas which alone they are capable of forming, owing to their deficiency in the generalizing faculty. We may expect that progress in theistic conceptions will, consequently, be apparent in those directions in which this faculty is first exercised; and the facts correspond to this expectation. Clearly, it will earliest become manifest in connection with natural phenomena which are of daily and familiar observation. While it is historically true that these ideas of ghosts, demons, sorcerers and ancestral spirits persist, and have wide influence even into periods of weli developed civilization, yet there will gradually emerge, in communities where circumstances are favorable to mental development, broader theistic ideas, arising from a widening classification of natural powers and

*Principles of Sociology. 
objects. Hence the evolution of mythologies, with their deities of the upper and nether worlds, of air, earth and ocean, assigned each to a specific province or function, and differentiated into ranks, orders and hierarchies. It is not possible to define clearly the line where pure fetishism ends and mythologizing begins. There is an element of mythology in all fetish-worship, through and by the idea of personification, which, invariably, as we have seen, underlies the latter; and, on the other hand, an element of fetishworship is discoverable in the most elaborate mythological systems. The broad difference, however, is between a fragmentary and disjointed view of things, and an orderly conception, or an attempt at it. Mythology is further specially characterized by the rise and growth of myths, or theistic legends, as the word implies. This of itself gives evidence of mental advance. When primitive man first attempted an explanation of the mysterious powers and activities around him, and, as a result, evolved the story and legend, he had begun to ask the question Why? and in fact had begun to philosophize. The numerous instances adduced by Spencer and others show that this tendency to mythmaking was in operation at the earliest periods, among the lowest tribes of which we have any account, co-eval with pure fetish-worship; insomuch so that we must concede the period when fetish-worship alone prevailed to have been antecedent to all records.

We have already, in considering the Evolution of Society, seen how, as a result of the integration, or consolidation of social structures, there results within the social structure itself, divisions into specific lines of action, among classes of its individual members. Primitive societies, loosely aggregated, exhibit no considerable diversity of trades, or governmental processes. These arise, and have been evolved into the modern highly complex social orders by the compacting of the social mass. 'The same principle is apparent in the evolution of the purely mental conceptions which underlie all theological development. It is only under what may be called an integration of theistic ideas that variety and classification among these become possible. For example, savages of a low type will take for their fetish-god any chance object which they believe will serve the purpose of bringing them success in their immediate undertaking, or afford them protection in immediate danger. But commu- 
nities which have reached the mythological stage proper, allow no such confusion in respect to the attributes and offices of their various deities. No Greek would ever have sacrificed to Neptune for success in agriculture, nor to Ceres for success in trade. The gods of the Assyrian, Babylonian, Greek and Roman pantheons have generally each their assigned rank and prerogatives. I say generally, for any student of these complicated mythologies knows that there is, in many instances, a duplication of attributes, especially among the so-called Olympic deities of Greece, and, though to a less extent, among the greater gods of the Roman system. But considering all these mythologies, each in its entirety, the principle holds good. To what extent this differentiation has been carried is best illustrated by the elaborate and complex mythology of the Hesiodic Theogony.

We have no space, nor is it the purpose here, to go into any detailed account of mythological systems. We have seen that they rest upon a wider generalization, and that by the working of a yet undisciplined Reason through the imagination, the myth is their special feature. We have to note, however, one other feature, and that is the separation, in the myth-system, of the personality of the god from the object with which the fetish-worshiper's mind identified him. Mythology conceives its gods as controlling the powers and phenomena of Nature, but as distinct from these in their personality. Zeus is not the thunderbolt itself, nor in, nor cf it, but as distinct therefrom, in his own individuality, as Minos or Hercules; and the separation is still more marked in the Roman system. This. peculiarity depends upon the rise in man of the idea of mind as distinct from body. The development of theistic ideas keeps even pace with the mental development of the nation. With advancing intelligence, arises the consciousness of mind and thought conceived as existing apart from mere bodily functions. This conception, as we have stated, primitive and savage races do not, grasp. Upon this distinction, when once fully established, is based the idea of the Self, viz., the essential personality of mind. The modifications of theism correspond. The gods become active intelligences, superhuman in faculty. The dominant gods become incarnations of the most powerful and controlling sentiments and ideals evolved by the national life, and in this transition we pass from the fetish-gods of mere brute-force to the deities of mind, and 
ultimately of pure intelligence, who are the exponents of an aggregate social life governed mainly by these ideas.

In further support of the statement that through the more highly organized and varied social state there arise the more highly organized and varied theisms, we have the fact that societies which have not become thus organized do not show in their mythologies the operation of this classifying principle to any such extent. The mythology of the early Axyans, as set forth in the Vedas, notably the Rig-Veda, remained, mostly, mere personifications of natural phenomena, which, to the mind of the early settler of Northern India, were the most impressive of all his experiences, and became the principal factor in all his theological conceptions. Aryan mythology is replete with storm-gods, gods of the Dawn and the Twilight and of solar and lunar phenomena, and these never became wholly disconnected from the substance of the phenomena themselves. Agni, the god of fire; Surya, of the sun; the Maruts, of the thunder and tempest, do not impress us with the idea of personality distinct from the elemental "forces with which they are associated. Indra possesses it in the highest degree, but the element of self-conscious intelligence is not prominent. Indra is the slayer of the dragon who withholds the blessing of the sunlight, and ranks with the mere power-gods. As a consequence, the religious thonght of India diverged on the one side into the system of the complex and absurd ceremonial-worship of the Brahmanas, and thereby, ultimately, into the manifold idolatries now prevailing; and, on the other, by a philosophical reaction, into the recondite and mystic philosophy of the Vedanta. The same unregulated ideas are discoverable in the Teutonic and Scandinavian mythologies. In both these instances there was no compact development of social or national life, and consequently no highly developed mythological system.

Moreover, as, in the well ordered State, the functions of government, and the regulation of the social order, the administration of law, and the permanence of family relationships and civil obligations are conspicuous features, all these will be reflected in the popular mythology where these conditions exist. So it was in the Greek and Roman States. Their mythologies are, essentially, governmental, and, as we might say, sociological. The mythologies of Assyria, Babylonia and Egypt are the reflex of the despotisms which 
there prevailed. The King being the God-incarnate, the religious sentiment was one of mere subjection, mostly unrelieved by any ethical features. Obedience and worship were first in consequence, and, although the ideas of sin and its punishment became early prominent in the Osiris-worship of Egypt, the subsequent rise to influence of the worship of $\mathrm{Ra}$ and Ammon largely obscured the moral idea inculcated by the older religion.

Mythology and fetish-worship are together properly included in the term polytheism. The issue out of these, by a slow evolution, of the monotheistic idea follows in the order of development. That such an idea was certain to emerge at some time and place in religious history, was an inevitable consequence of the advance in the generalizing faculty possessed by man. The same impulse towards centralization in theistic ideas, by which he rose from the disconnected and unrelated fancies of fetish-worship to a rational mythology, compelled a further advance to monotheism, - to the conception of a Primal Being, a single Source, a Unity which should be comprehensive of all phenomena, the sole result which would satisfy man's advancing thought. If the immediate outcome was essentially an anthropomorphic conception, it was still an immense advance upon the miscellaneous and kaleidoscopic mythologies of polytheism; though these had claimed good reason for existence, as transitional and, indeed, necessary phases. That the monotheistic idea was mainly given to the world through the medium of Hebrew thought is a circumstance due to the subjection of the Hebrew race to a mental and social environment favorable to the development of this idea arnong them. It was the evolution there of a germ implanted in the human mind everywhere. Every polytheism has within itself the "promise and potency" of monotheism. The Hebrew did not consciously formulate the doctrine on philosophical principles, - it was a growth with him. That there has existed among many peoples and races what we may term a monotheistic sub-consciousness has been ably shown by Mr. S. Baring-Gould,* by evidences which are conclusive. "Although Mosaism," says he, "must be regarded as the mother of Christianity and Islamism, yet classic antiquity, behind its imagery of myth and above its pantheon, recognized, feebly and fitfully, it is true, but

* Origin and Development of Religious Belief. 
nevertheless really, the Unity of the Godhead. It is possible to form an almost complete system of monotheism from the Greek and Latin authors, which fact, if it does not prove that such a system had been precipitated into dogma, at least shows that it floated in the classic mind. *** Among the barbarous races of Africa and America, from behind the veil of myth, flash occasional gleams from the face of the One God." To the instances collated by him we may add the Dyaus-Pitar of Vedic mythology. The discussion, for and against Prof. Max Muller's claim that this is a true monotheistic conception, whichever way determined, serves to bring into relief the truth our author insists upon.

Before passing to a brief further word on Hebrew monotheism, we must take note of an intermediate development; that is, intermediate in the development of theistic ideas, viz., the dualistic theologies. Of these we recognize three schools: the strict theistic dualism of the Persians, the mythological dualism of the Gnostics and the philosophical dualism of the Neo-Platonists and the Kabbalists. Dualism is simply a step in advance beyond polytheism, and, in the natural sequence of religious thought, it issues in monotheism. In Dualism, the factors, or at least the leading factors in the system are reduced to two,-again a proof of the tendency of the mind to progress from lesser to wider generalizations. In the case of the Persian religion, the duality was based upon the mutually opposing principles of Good and Evil, which, as embodied and personified respectively in Ormuzd and Ahriman, constituted a true theistic dualism; although, as subordinate to these, inferior deities, proceeding from the highest by emanation, were admitted to exist. The Gnostic systems, both the Syrian and Alexandrian, and the later more abstruse Neo-Platonism, with all their manifold unreal speculations and factitious systems, rested fundamentally upon the conception of Mind as opposed to Matter, and of Absolute Being as opposed to the world-phenomena. The philosophical interest for the history of religious thought in all these, is in the efforts therein made to solve the problems of apparent diversity in an underlying Unity, and to account for the reason of the existence of antagonistic forces in Man and Nature.

It was not so much that the Hebrew prepared the way for the reception of monotheism as a philosophical idea, but that he infused into this idea a profoundly religious and 
ethical significance, which gave to it its wonderful power of deeply and permanently moulding the future of religions speculation, and transforming previous ideas. But this result was reached only after centuries of discipline and teaching. The Yahweh of early Hebraism was admittedly the god of the Hebrews only. That other tribes and nations had also their tribal and national gods was not then questioned. Yahweh was simply greater than surrounding gods. His worship was deeply tinged with the hideous sacrifices of Baal and Moloch worship, and the continual lapsing of the people into a worship of other gods proves that the lofty monotheistic ideas of a subsequent time were not an inspiration from the people at large. They were the outcome of the prophetic teaching, holding forth, with unswerving zeal, in spite of gross idolatries and of national defeat and captivity, the icleal of a Deity of Righteousness and Mercy. The rise of what may be called Judicial and Moral Theology is thereby mainly due to Hebrew prophecy.

With the arrival at a true monotheism we reach the close of Objective Anthropomorphism,-i. e., gods conceived in merely objective and physical aspects; and attain to a true Subjective Anthropomorphism, i. e., Deity conceived under judicial and moral attributes. It was immensely to the advantage of religious speculation that the Hebrew idea, when it went forth to take possession of the civilized world, to the discomfiture of incongruous and decaying polytheisms, should be thus centred upon this conception of Moral Excellence as its controlling thought. Indeed, without it, it would have gone nowhere and come to naught. Had Hebrew theism, simply by insisting upon the worship of the ancient Yahweh as a Nature-God, attempted to force its ideal upon other nations, it would properly have been met with the answer that the Greek Zeus and Roman Jupiter fully satisfied the ideal. As a result of the essential difference between the two, while the entire pantheon of Greek and Roman divinities passed into oblivion under the criticism and ridicule of the schools of philosophy, and left in their place nothing but avowed atheism and barren skepticism, which, in time, led to an utter debasement of public and private morals, the conception developed by the Hebrew, resting substantially upon the ideals of justice and right conduct, contained within itself a principle of vitality which could and did expand with the advance in 
moral sentiment among all by whom the idea was accepted. 'The Hebrew Yahweh - divested however, almost wholly, at least among the more intelligent, of purely objective personality, and conceived under his moral attributes - is to-day the God of Christendom.

There have been, however, two easily recognized stages of development, and this accounts for the use of the terms judicial and moral theism, or theology. By judicial theology I mean that system in which Deity is viewed mainly in the aspect of a Judge and Avenger. This was the older and severer phase of Hebraism. The sin is against Yahweh, and not primarily against the neighbor, and it is for the former that atonement is offered. Deifications of physical forces cease with the growth of moral ideas. But these, as the history of morals clearly proves, are not in the first instance properly ethical ideas. The stress is upon the duties owed to Deity. It is the infraction of these which provokes to anger and demands propitiation. Adam is punished solely for disobedience to a command of the Lord, not for sin against another. This is characteristic of the Hebrew theological idea down to the preaching of the prophets, who, as has been remarked, contributed mostly to the truly ethical element, and insisted upon justice to the fellow-man, personal righteousness, and the subordination to these of ceremonial and sacrifice, or the abolition of the latter altogether. Christianity for the first two centuries was an amplification of the prophetical ideas in the direction of a pure morality. The doctrine of the sin against God, and the consequent necessity of an atonement to an offended Deity, was revived with the later schools of philosophical theology, and remains embodied in the creeds of modern times, - with this essential difference, however, that the ethical school of theology is fast gaining recognition, as is evidenced by the growth of the new views which seek to place religious obligation upon the basis of conduct rather than upon the lines of systematic theology. An advance is perceptibly being made towards a truly ethical monotheism.

This necessarily brief outline brings us to the close of the history of theism so far as this has developed into established systems of belief. These ideas of Deity as a Righteous Judge and Moral Governor control the beliefs of the present, and the various existing creeds are expansions of 
them, in logical form. With these we have not to do, otherwise than in their relation to the conception of a Deity. Discussion of the specialized dogmas of the Christian creeds belongs to the domain of Christian Dogmatics.

But in stating that modern theism, so far as developed into existing ecclesiastical institutions, rests upon these ideas, we do not imply that further evolution has not taken place in religious thought. In our previous examination we have shown how the mind has, by slow successive stages, risen from particulars to generals, and have reached the monotheistic Christian idea of a Divine Personality characterized by self-conscious intelligence. But there have been, at all times, some who have objected to any conception of Deity under any limitations of Personality, subjective as well as objective. God conceived as a Personality, under any implications of that word, or conceived as in any wise consciously existing as a separate Entity apart from the totality of things, or as operating upon matter external to himself, has been and is, to them, not only intellectually impossible but morally objectionable, as a limitation of Infinite Power, and derogatory to the idea of an Infinite Deity. The evolution of the various forms of Pantheism has been the result, both materialistic and idealistic; the former merging all existence, and thought as well, in matter; the latter resolving everything into the ideal, or into forms of thought. The Pantheist is forced into his position by the same impulse of the educated mind towards wider generalizations which compels fetishism to yield to mythology and the latter to monotheism. In other words, the Pantheist claims that the prevailing monotheism is, in fact, a dualism and not a proper monotheism at all ; that Deity on the one side and the Universe of Matter and Man on the other is really no advance, philosophically, upon the Gnostic or Neo-Platonic theory. Pantheism, by merging the two, endeavor's to arrive at the conception of the All-God, as the word strictly implies, and seeks for a basic Monism as the ground of all existence and phenomena. Pantheism, to the mind of many, is synonymous with ungodly atheism. But something closely allied to Pantheism must be the true, rational and reverent theism, unless we choose to rest in such partial and limited ideas, descriptive of the Infinite, as those which abound in the current theology. The fact is, however, that not a creed has ever been formulated which 
does not, in its setting forth of the Nature and Attributes of God, contain the germ, essentially, of a Pantheism as radical as has ever been propounded from Spinoza to Spencer. Omniscience, Omnipresence and Omnipotence, as used in articles of belief and confessions of faith, are words void of meaning except with pantheistic implications. Expand these and similar words, under metaphysical treatment, and any idea of Personality and Self-Consciousness in Deity must disappear, in any sense in which words are used by us or understood among us. This conclusion does not certainly dispose of the question whether, in the last analysis, if we could make it, some quality or attribute corresponding to Personality and Consciousness may not be found to exist in the Infinite. It is reasonable to claim that, as the stream cannot rise higher than its source, the fact that human personality and self-consciousness have been evolved in mental progress, argues that something higher than this, not something lower, has been its origin; but any such expressions as Infinite Personality or Infinite Consciousness are so wholly beyond our mental reach that they escape all comprehension.

Pantheism has taken forms as varying as the different views of the Universe which the philosophies of the world have set forth, and an account of them here is impossible. In all of them the search is for a fundamental Unity, and they can not be charged with irreligion. A rational religion has been the object of all, except the comparatively few systems in which the ultra-materialistic view has led to atheism. The expressions Universal Mind, Universal Soul, are the terms in which idealistic Pantheism strives to realize in thought those more comprehensive views which it professes.

Beyond Pantheism there is but one farther step which can be taken. The Philosophy of the Absolute will accept not even the terms Universal Mind, Soul, or Spirit. It insists that these phases are but expansions of merely human ideas of personal mind, soul or spirit, and still, therefore, imply a limitation which does not allow a free development of a true doctrine of the Infinite. These words still imply consciousness, and that implies limitation. The question is discussed necessarily upon metaphysical lines exclusively, and is substantially this: 'The Intinite, ex vi termini, is that which is without limit, and, so conceived, is an original and 
not a derived form of thought. To affirm limitations or relations in an Infinite, in any possible aspect either of thought or existence, is to fundamentally destroy the very idea of an Infinite. Now, all merely human thought and existence arise and levelop under certain well known and recognized limitations of Time, Space and physical and mental activity. In short, all human mind and action are inexorably conditioned by certain external factors, viz., natural forces and social forces; and also by certain subjective factors, viz., processes of mental action, which become known to us in the light of consciousness. But what is consciousness, and what does it imply? What consciousness is, in and of itself, must remain forever unknown to us. It is simply "the light of all our seeing." It, however, involves two things: first, a person who is conscious; secondly, a something external to himself of which he is conscious. That is, a subject, the person; and an object external to him, upon which he exercises his faculty of perception. Human consciousness, and therefore all human knowledge, are wholly relative; but this cannot be the case with the Infinite. To apply such conditions to the Infinite would be to affirm that the Infinite cognized something external to itself as an object of knowledge. It would impose upon it a limitation which would be destructive to the Idea. Nor can we in anywise seek to express the Infinite in any form of definition. We must simply affirm that it is and there cease; for all definition must be in terms of human speech, and therefore essentially fail to conform to the Idea, - as much so as if we attempted to express the idea of infinite space by the measurements of a yard-stick.

We must, therefore, says this latest school, cease from all speculation as to the essential nature and mode of being of the Infinite, and accept an Absolute which is to us Unknowable as the primary philosophical conception. "The Absolute," to quote the words of Dean Mansel, " is a term expressing no object of thought, but only a denial of the relation by which Thought is constituted."

The Doctrine of the Absolute, declining to describe the Infinite in terms even of Universal Soul or Universal Mind, brings us to the ultimate, most abstract position which Metaphysics and Speculation can reach, beyond which there can be nothing further, unless we choose to deliver ourselves over to

\footnotetext{
* Limits of Religions Thought.
} 
atheism, which is not only the negation of religion, but also of philosophy. Of Agnosticism and Positivism I have not spoken. Agnosticism is simply an attitude of the mind towards all theological speculation, and refuses to enter upon it, claiming all such questions to be insoluble from the nature of the case. Positivism on the theistic sicle is also agnostic, and therefore devotes itself exclusively to the amelioration of the social order. These, therefore, yield nothing to the history of theism in the way of constructive thouglit.

It is not claimed, and could not be, that religious history shows, in any part of the world, a consecutive development of all these successive phases of theistic belief. In every nation, some one of them has been mostly predominant. Pantheistic and similar views have been the outcome of individual speculation, at least in later times, and have arisen from the philosophical schools. The tendency of the general movement, however, wherever there has been movement, is along the same lines as in scientific thought, viz., from narrower to wicler generalization. This is characteristic of it as a whole,-following, thereby, the natural order of the Evolution of Mind, and, so far as it does so, or is allowed freely to do so, progressing from the lower to the higher ideals. according to the true law of developinent.*

* It is manifestly impossible to do more than suggest the position of the Doctrine of the Absolute, in its relation to prior views. The object is only to show how it stands related to previous philosophies as the ultimate and necessarily final generalization. We should note, however, that while Mr. Spencer accepts the conclusion above quoted from Dr. Mansel, as a loffical consequence of his premises, he asserts, nevertheless, the valid existence of what he terms an "indefinite consciousness" of the Absolute, which, as entering necessarily in all contemplation of the Absolute, is an ineradicable factor therein, and that this is the sufficient basis for all essentially religious ideas, whereby in fact all that there is essentially religious in all phases of theistic belief has been preserved.

Further discussion here is impossible. The reader must be referred to $\mathrm{Mr}$. Spencer's "First Principles." An interesting" and thoughtful criticue upon Mr. Spencer's views as to this "indefinite consciousness" considered in reference to, and in comparison with, his doctrine of the relativity of ideas, will be found in the first part of Prof. John Caird's "Philosophy of Religion." Mr. Spencer contends that his doctrine of the Absolute is not a negation; that it is the highest possible affirmation. It is a plenum, and not a vacum, It is perhaps somewhat unfortunate that he should have entitled the first part of the First Principles, "The Unknowable," thus giving' occasion for much useless and worthless criticism of the Synthetic Philosophy as essentially destructive and not constructive. "The Absolute is Unknowable," is the idea therein presented, although the words are used more or less interchangeably. 


\section{ABSTRACT OF THE DISCUSSION.}

\section{Mr. Frederick B. Hawley:-}

I am in such substantial accord with the lecturer, that I will merely take up the subject where he has left it, and touch upon some of the present phases of the evolution of theology. Looking toward the future, we must be careful not to take too long a step in theological progress at once. From the theistic belief of Christendom, with its man-God and its special providences, to a belief in the Infinite and Absolute - the Unknowable of Mr. Spencer's philosophy - is a very long step indeed. God and immortality are the ruling ideas of the present theology. As to immortality, the doctrine of the persistence of force goes far to justify us in such a belief, though perhaps not in that of the continuance of personal consciousness. That which we know as mind and thought must persist in some form: it cannot be destroyed. The current theistic idea of God is a combination of human and infinite attributes. Such a union is unthinkable, and these ideas must ultimately be disassociated. The conception of Deity must be deanthropomorphized. There has already been a gradual readjustment of theological ideas, and the trend of modern thought is in harmony with the evolution philosophy. I must take exception to the lecturer's position as to consciousness. Consciousness, it appears to me, is not necessarily finite, or limited to the human mind. It can be conceived as an attribute of the Infinite.

\section{Mr. Thaddeus B. Wakenan:-}

Notwithstanding the quarrels of the philosophers as to the priority of certain phases of theological belief - whether ancestorworship preceded or followed idol-worship, etc.,-it is evident that Fetishism was the foundation of theology. Then came Sabæanism, and, following this, Polytheism. The next great change was from Polytheism to Monotheism. Monotheism broke down with the downfall of its cosmogony. The final outcome of theological evolution is Positivism. Its conception of deity is that of pantheism - the conception of the All - "Das Alle," in Goethe's words. We cannot attribute to this great All our human thoughts and limitations. But we can understand some of its laws, and, adapting ourselves to them, strive for the perfection of humanity. The idea of Humanity stands as the mediator between the human mind and the All. It takes the place of the Christian Saviour and 
God, and replaces the theologic immortality with an earthly beyond instead of a heavenly above. It is astonishing to find this discussion of the evolution of the god-idea conducted in a church. This notable event begins the day of hope for the emancipation of the human mind from superstition.

Rev. Dr. Gustav Gottheil:-

I may say that I am a living example of the development of Jewish theology. Perhaps Mr. Wakeman would say that the Jewish race has been kept back three thousand years by its belief in a personal God; but this belief, which I hold most firmly, has not prevented me from studying and understanding philosophical opinions on these questions. As respects a belief in evolution, I am an agnostic, because, for one thing, evolution seems to have come to a stop, satisfied, leaving nothing for the future to do. Are we to progress no further in our thought? Abraham's idea of God may have been as noble as the modern idea. We do not derive our ideas of God from the outside world. There is in man a faculty which can conceive of God. We must look to that for the origin of theology - not to fetishism or idolatry. The lecturer has critieised the Jewish fealty to God rather than to man. But really this is the higher thought: We love our neighbor, not because he is always lovable, but because God has imposed upon us the obligation to love him. Why should you love humanity? There is nothing in nature from which to derive a law of obligation. Modern thinkers speak the ethical language of the ancient religion without believing in its God - apparently; though at heart they do believe in him. The Jewish belief in rival gods was never held by the noblest of our race. It was discarded by all as early as the eighth century before our era. The Jewish God is the ancestor of all theism. Man's moral nature must have been formed from the conception of a moral God. Judaism, as the mother of Christianity, should be treated with more respect. Judaism has not passed through the "three stages" of theological, metaphysical and positive thought: it has remained theological throughout. Is it the worse for this? Monotheistic religions will furnish in the future, as they have in the past, the energy for reforming the world. As to immortality, I have a right to demand the continuance of my existence, which has cost so much effort and endeavor.

\section{Rev. Joun W. Ciradwick:-}

"Who shall come after the King?" However much we may disagree with Dr. Gottheil, we must all admit that his was a right 
royal word. I cannot agree, however, with his account of the origin of morality. Religion and morality had separate sources they are often separate in the lives of men. Colonel Ingersoll holds some rational views in an illiberal way, but he spoke well when he inverted the popular epigram, and made it read, "An honest God's the noblest work of man." I must disagree with Dr. Gottheil, and affirm that the ascription of morality to the Jewish God followed, and did not precede, the development of a higher morality among the Jewish people. It is equally foolish and irrational to be too familiar with God, and to take the position that we have gotten through with him. The trouble with Positivism, notwithstanding its many grand and noble ideas, which have been an inspiration to me throughout my ministry, is that it rested in the metaphysical stage of development, giving to the abstraction "Humanity," the guise of personality.

"Unless above himself he can erect himself, How poor a thing is man!"

Not only above the humble ones but above all, including the greatest of human kind. Where did humanity come from? Back of man, of "humanity," is the earth ; back of the earth there must be "an Infinite and Eternal Energy whence all things proceed." To that I bow my heart; that I worship, not altogether ignorantly and foolishly, I believe.

Dr. Lewis G. JANES:-

It seems to me that this question of the consciousness and personality of the Absolute may well be left where Mr. Spencer has left it. He affirms, in substance, that if we may not assertpersonality and consciousness of the "Infinite and Eternal Energy whence alk things proceed," we may be assured that its state is not lower, but infinitely higher than that which we denote by these terms. As evolutionists, we seem justified in affirming this; otherwise we assert inferentially that these traits have been created, not evolved. Logically, the lower cannot produce the higher. That must be involved in the totality of things which is evolved in the differentiated individual. As evolutionists, let us not be entrapped by the faulty logic of the special-creationist. 



\section{EVOLUTION OF MORALS}

BI

LEWIS G. JANES

Author of "A STlin of Primitive Christiaxity," "The Holution of the Earth," ETC, ETC. 


\section{COLLATERAL READINGS SUGGESTED}

IN CONNECTION WITII ESSAY XI.

Spencer's Psychology, Data of Ethics, and Ethics of Kant (in Fortnightly Review, July, 188s, and Popular Science Monthly, September, 1888) ; Fiske's Cosmic Philosophy; Bain's Moral Science; Staniland Wake's Evolution of Morality; Savage's Morals of Evolution; Thompson's Problem of Evil ; Schurman's Kantian Ethics and Ethics of Evolution, and Ethical Import of Darwinism; Clifford's Scientific Basis of Morals (in Contemporary Review, September, 1875); Sheldon Amos's Science of Law; Dr. C. C. Everett's Essay on The Nev Ethics (in Unitarian Review, October, 1878); Frances Power Cobbe's Darwinism in Morals; On a Moral Sense, in Darwin's Descent of Man. 


\section{EVOLUTION OF MORALS.*}

"Virtue is the alherence in action to the nature of things, and the nature of things makes it prevalent."

Ralpir Walmo Emerson: Spiritual Laws.

I ${ }^{2}$ has been tersely said that "the moral is the measure of health." This is true not only of man, but of ideas, of institutions, of religions, and of philosophical systems. These, too, are rightly regarded with suspicion if found wanting when subjected to the moral test. A system of thought doubtless finds its ultimate sanctions in evidences appealing to the intellect; but any apparent deficiencies on the ethical side, affecting the guidance of conduct and the development of character, should justly subject its claims to renewed and rigid scrutiny. That only is completely reasonable which is sane, healthy, moral.

It is precisely on this ground that the Evolution philosophy has been most violently assailed by its critics. This fact, however, should not of itself create distrust of the essential validity of the philosophy. Such assaults have been the common fate of all new systems of thought, since man began to drop the plummets of his reason into the ocean-depths of his physical and psychical being and environment. To the conservative mind, the new and untrodden path always seems full of dangers. The turn-pike road of the fathers is the safe and narrow way. The engineer who sets out through the wilderness to survey a path for the iron rails, is committing an act of sacrilege and impiety. Seeing that this is so, it behooves us nevertheless to look well to the ethical foundations of this new doctrine of Evolution. The welfare of men and of kingdoms may depend upon their stability and strength.

The present age is a period of transition. Old sanctions are being undermined. Man fronts the Universe and the problems of life in a new attitude. The revolution in thought through which we are passing has been well termed, by

* Copyright, 1889, by The New Ideal Publishing Co. 
Mr. Savage, "A change of front of the Universe." It is the passage of man, in his mental estate, from dependent childhood to self-reliant manhood - always a critical and dangerous period in the history of the individual, none the less critical and dangerous in the life of a nation or a civilization. Heretofore the ethical systems of the world have, in the main, rested on the sanctions of theology - upon man's thought of God - instead of upon the Divine Reality as revealed in the nature of things. It has been assumed that man's supreme obligations were due to God or the gods, as he conceived them, and that they were enforced by a system of rewards and penalties to be bestowed or inflicted in a future state of existence. The new philosophy affirms that man's primary obligation is to his fellow-man - that duty grows out of the necessities of social communion; that it is founded in the nature of things, instead of in the arbitrary will of an absent deity; that its penalties are not extrinsic but intrinsic - that they are registered immediately on the tablets of character, and their enforcement is dependent upon no speculative beliefs, whatever may be the theological implications involved in such beliefs. The old sanctions, resting on theology, are losing their force and efficacy in all thinking minds. A few only, as yet, comprehend the significance and bearing of modern rcientific thought, and especially of the doctrine of evolution, upon the foundations of morality; hence the assumed and not altogether imaginary danger of a "moral interregnum" - a temporary lapse into laxity of thought and depravity of life.

Intuitional metaphysics joins with theology in the attempt to discredit the foundations of evolutionary ethics. The sanctions of morality, it declares, rest not indeed upon the arbitrary mandates of deity, but upon the nature of the human mind. The sense of obligation is a primary intuition of consciousness. It has had no causal genesis-no historical evolution. Its "ought" is the "categorical imperative," which cannot be analyzed, scientifically investigated, or traced to any less definite or coherent substratum of primitive impulse. The intuitive system appeals for rational recognition by its fundamental assumption of the supremacy of reason, and affirms its competence to deal with the problems of philosophy and psychology by the deductive or a priori method, independent of the facts of experience. 
In ethics, it rejects as incompetent all moral judgments based upon experiential tests.

The actual bearing of the doctrine thus assailed, upon ethical sanctions, may best be understood by the study of its theory of the genesis and development of the moral sense. It should be said at the outset, however, that the leading representatives of the new school of thought by no means admit the validity of these charges of their critics. The evolution philosophy affirms the supremacy of ethics, and makes moral science the culmination of its entire system of thought. "My ultimate purpose," says Mr. Spencer, in his preface to the Data of Ethics, "lying behind all proximate purposes, has been that of finding for the principles of right and wrong, in conduct at large, a scientific basis." In its investigation of morals, the new philosophy lays its foundation upon the solid rock of fact, as revealed in human experience. Its ethical structure does not rest upon a cloud-fabric of theological or metaphysical assumption, but upon human nature itself _ upon man's natural desire and effort to make the most of life, both in its personal and its social aspects, and upon the observed good or evil effects of actions, juclged by this practical test. In collecting and collating its facts, it follows the scientific method - studying man as he exists to-day, and as he has existed throughout the entire period of his evolution. As in the field of the physical sciences, commencing with the historical era, it prolongs its vision into prehistoric times by a legitimate use of the scientific imagination. By the study of savage races and the investigation of language and archæological remains, it forrus a vivid conception of man as he was gradually outgrowing the inheritance of his brute ancestry, and progressing toward civilization.

Even more deeply than this, the Evolution philosophy searches for facts on which to rest its science of morals. It perceives that moral conduct is only a part of a larger whole-conduct in general. It is necessary, therefore, to study conduct first in its universal aspect, in order rightly to estimate the nature and status of ethical conduct. Conduct may be tersely defined, in the language of Mr. Spencer, as "acts adjusted to ends." * It includes only those actions which are accompanied by volition, excluding those which are automatic and mechanical. In the lower forms of or- 
ganic life, consciousness is vague, indefinite, and protoplasmic - limited to mere sentience in its most primitive and undifferentiated form. Such organisms manifest but little evidence of definite, conscious purpose. Their action is mainly automatic, in response to external stimuli. The polyp has $n$ special organs of sense; it does not even seek intelligently for its food, or manifest a definite purpose to propagate its kind. Its action is more like that of a vegetable than a conscious being. Attached to a support, it appropriates suitable articles of nourishment whenever they are brought in contact with it by the action of external forces. It propagates its race by gemmation or budding, like a vegetable organism. The differentiation of purposeful actions, as we ascend the scale of being, is a gradual and progressive process - a process of evolution. With greater complexity of structure, we find an ever-increasing number of purposeful actions, directed toward definite and intelligible ends. Food is intelligently sought, instead of being passively appropriated from accidental contact. Dangers are intentionally avoided. Life becomes less the sport of accident - comes more and more within the scope of intelligent volition. The probability of fulfilling its natural period steadily increases as we advance from infusorium to ascidian, from ascidian to fish, from fish to reptile, from reptile to mammal, from brute to man. Life not only increases in relative duration, but also in breadth or amount. Conduct increases in complexity as it reaches successively higher stages of evolution. In estimating the relative position of an organism in the scale of being, we must consicler not merely the length of its life, but rather the sum of its vital activities. The elephant lives longer than man, but it does not live as much as man. Its activities are fewer, its adjustments of acts to ends less definite and numerous. This principle of the gradual evolution of conduct in definiteness and complexity applies not only to conduct in general, but also, evidently, to those volitional acts which constitute the yet undifferentiated protoplasm of moral conduct.

The primary motive which governs the purposeful actions of the lower organisms is the desire for self-preservation. Their voluntary movements are directed to securing nutriment, and to escaping from dangers which threaten to terminate their existence. Propagating with marvelous 
rapidity, the contest for existence forces them into competition and conflict with their kind, as well as into the struggle against the inertia or opposition of natural forces. Thus the problem of life steadily increases in complexity. It demands greater activities of mind and body, and the demand induces the supply. Out of the desire and purpose to live, and the conflict consequent upon action in accordance with that purpose, - the inter-action of intelligent volition in the organism and the stress of environing conditions,have grown all the splendors of the intellectual activities, all the diversified wonders of organic structure and function.

As intelligence increases, it is at length naturally perceived that the welfare of the individual organism is largely dependent upon the preservation and perpetuation of the race. The latter end, after a time, to some degree supplants the primitive impulse for self-preservation as a conscious motive for voluntary effort. In the lowest organisms the race is perpetuated without conscious purpose - sometimes by fission, or automatic sub-division, each section or part of an original unitary organism forming, when separated, an independent individual. This process is automatically initiated whenever increasing size in the organism, or diminished food-supply, renders nourishment too difficult; or when other physical conditions over which the organism has no voluntary control, operate to produce a like result. The action is purely instinctive and purposeless. Higher in the scale of being, intelligence co-operates more and more with inherited instinct in securing race-perpetuation. Offspring require and receive more care. Many of the higher animals will risk their own lives, or deprive themselves of food, to protect or feed their mates or their young during the breeding season.

Accepting the Darwinian account of man's origin,* we must conceive of him as emerging from brutehood possessed of these two inherited instincts of self-preservation and race-perpetuation. The historical period evidently constitutes but the smallest fraction of the time during which he has existed on the earth. Some six or seven thousand years, at most, bring us to the beginnings of human history; but the facts of man's present condition, and the evidence of ancient monuments and archæological remains, render it necessary for us to assume a period of several hundred 
thousand years since man was derived from that old-world ape, "probably arboreal in its habits," which Mr. Darwin regards as man's immediate ancestor. Into this dim past, griided by such facts as we may obtain from archreological, philological and aboriginal studies, we must prolong our mental vision, and form such conception as we may of the characters of our early ancestors, and the probable facts involved in the evolution of man's moral nature.

Somehow, in the struggle for existence, primitive man had evolved greater intellectual capacity and acuteness than the brute-creatures by whom he was surrounded. His relative feebleness, and the consequent adversities against which he had to struggle, doubtless helped to secure this result. It is this intellectual characteristic - closely related on its biological side to the development and possession of a fore-limb and hand capable of manual dexterity, and the physical organs and intellectual possibility of speech - which, in the judgment of Mr. Darwin, differentiates man from the lower animals. This superior intellectnal capacity has its bearing on the evolution of conduct, as we have already seen; but a fact even more pertinent to our inquiry, as Mr. Fiske has shown, * is the lengthening of the period of infancy, which necessitated more prolonged care for the offspring of man's progenitor than that which is bestowed by any other animal. It was registered in the great Book of Life, of which man's history constitutes the latest chapter, that only by becoming as a little child could he enter into the high heaven of moral aspiration and endeavor.

The earliest instincts of primitive man were doubtless purely egoistic, like those of the brutes; they were not immoral, properly speaking, but nn-moral; the moral sense was as yet undeveloped. If proof of this assertion is needed, it may be found in the study of language - in the investigation of the origins of those words which we now use to lefine and express ethical conceptions. "If we examine the words, those oldest prehistoric testimonies," says Geiger, an eminent philological authority, "we shall find that all [expressions of] moral notions contain something morally indifferent." 'The original meaning of "right," for example, is straight; of "wrong," vrung or crooked. "Conscience" has primarily an intellectual, "ought" and "duty"

* Fiske's Cosmic Philosophy. 
a commercial, not a moral signification. These words come to represent ethical ideas only by a process of metaphorical transformation. "But why," continues the authority just quoted, "have not the morally good and bad their own names in language? Why do we know them from something else that previously had its appellation? Evidently because language dates from a period when a moral judgment, a knowledge of good and evil, had not yet dawned in the lumman mind." *

With some of the higher animals, primitive man inheriterl, however, in common with the gregarious instinct, an instinctive sympathetic quality in which Mr. Darwin distinguishes the germs of morality. $\dagger$ These earliest social tendencies, as well as those subsequently developed, are directly related to that steady increase of population, which intensified the struggle for existence, and thereby compelled greater activity of body and intellect in the effort to preserve life. As this process progressed, man's conduct. became more highly differentiated and evolved than that of any other animal. Memory became more vivid and comprehensive. He looked backward and compared the effects of his past actions, as determined by diverse motives, and was influenced by this recollection when similar emergencies arose thereafter. $\neq$ As all his motives were egoistic, looking toward self-preservation and self-gratification, his conduct cannot, however, yet be regarded as moral. If the instinct for self-preservation could be satisfied by protecting and ministering to companion and offspring, well and good; if, as he judged, by their destruction, no moral scruples stood in the way of his deadly purpose.

The long period of infancy nevertheless held the family together, and necessitated a continuance of those acts of mutual forbearance and affection which cease among animals. when the young are able to make shift for themselves. The mother ministered to the child, while the father gathered food and protected the family from wild beasts and savage men. Other children came, perhaps, before the care of the mother over the first-born could be relaxed. So, in the rude cave-dwelling, grew up the germ of the home - the earliest.

* Geiger's Address delivered to the Merchants of Frankfort-on-the-Main. In the Australian, and some other languages of extant savage races, there are no words to express justice, or moral obligation, sin or guilt.

$\dagger$ Darwin's Descent of Man.

† Ibid., I., 1) 19. 99, 100 . 
example of the permanent family relation.* 'The preservation of the family became recognized as essential to the life and happiness of the individual. The family became a larger self, and toward the preservation of this self instead of the individual self, the efforts of each member of the family were directed. $\dagger$ 'This change involved still greater' complexity in the adjustment of acts to ends - more active intelligence, greater fulness and length of life : - in a word, a higher evolution of conduct. It was probably during this earliest stage of social evolution that language was evolved, giving a great impulse both to intellectual development, and to that tendency to social combination out of which has grown the moral sense. "Any being," says Darwin, "if it vary, however slightly, in a manner profitable to itself, will have a better chance of surviving, and thus be naturally selecterl." Such a variation, evidently, was this change in conduct, as a higher order of intelligence and greater facilities for social communication were evolved. The vital activities, no longer exhausted in the struggle to live and the effort to perpetuate the race, turned naturally into other channels. As a larger average number of individuals reached maturity, reproductive activities were diminished and the struggle for existence was ameliorated. $\neq$ The law of competitive contest which, superficially regarded, seemed to threaten either universal selfishness or mniversal destruction, was found to contain the proper antidote for these evils in the natural result of its own operation. The cooperative family, it is evident, would be better able to cope with unfavorable conditions in the struggle for existence than the lone anthropoid progenitor of man had ever been.§

The growth of the family-self into the tribal-self, of the tribe into the city and State, doubtless proceeded along the lines which we have already indicated in describing the evolution of the family; resulting in a gradual enlargement of the area of altruistic service, a constant diminution of warfare and struggle, a higher order of individual and social life. Our study of the evolution of society has proved to

* It is not assumed that the monogamic family constituted the earliest form of the domestic relation. Doubtless polygamous and polyandrous relations succeeded the primitive herdal (gregarious) habits of man's progenitors, preceding the monogamic family in the order of evolution. The theory of moral evolution lierewith set fortl requires only a permanent family relationship, however constituted.

† Wake's Evolution of Morality.

Spencer's Essay on the Law of Population.

\$Lone, though gregarious, because his motives were fundamentally egoistic. 
us that the great nations of antiquity, and the civilizations of our own time were developed from the primitive family as the social unit. The family altar has ever been the school for the moral culture of the race. The full significance of these facts of social evolution, in their relation to our topic, is only made manifest when we perceive that throughout the entire process, from its beginning in the rude cave-dwellings of primitive man, the obligation to serve others has been substituted ever more and more widely for the obligation to serve one's self, as the conscious motive in the government of conduct. Man has progressively identified lis individual welfare with that of ever-increasing numbers of his fellow-men. The instinct of obligation is, indeed, intuitive from the beginning; an inheritance not only from man's brute-progenitors, but from far away origins in the operations of inorganic forces. It is akin to those instinctive gropings of vegetable forms, deep-buried in the earth, for light and nourishment. It impelled volition in the lowest conscious adaptations of acts to ends. In its primitive form, however, it was an egoistic, not a moral impulse. The "ought" of primitive man was not a moral obligation; it was a recognition of something oued to himself. The sense of duty, as we understand it, was not born until the secondary and indirect motive of race-maintenance and altruistic service was consciously and voluntarily substituted for the primary, egoistic motive of self-preservation and self-gratification. By this substitution,- the gradual and entirely natural result of growing intelligence and pleasurable experience in altruistic service,-conscious altruistic feeling and desire have grown out of egoism, Duty has supplanted an animal instinct. Yet here has been no creation, but merely a process of transformation, of evolution. The "raw-material" of morality is found in the simplest orderly manifestations of volitional activities in organic nature; - yes, back even in those steadfast laws and tendencies which are manifest in the action of the inorganic universe. Stability, order, law, evolutionary tendency - these are the essential elements in morality, as in the differentiation and integration of nebulous matter, and the movements of the planets around their central suns. In the last analysis it is not two things that fill the mind with awe, as in the familiar phrase of Kant, but one thing, whether it 
be manifested in the order of the galaxies, or in the orderly impulse to right action which we term Conscience or Duty.

Perhaps the modus operundi of moral evolution may be better understood by studying the psychological principles underlying the entire process of organic development from yet another point of view. The growth of the manifold faculties of sentient organisms can only be understood on the fundamental assumption that life is inherently good, and that each successive stage in the evolution of life is productive, on the whole, of an increase in the sum total of subjective satisfactions.* In order to survive in the struggle for existence, each organism and race must adapt itself to its environment. Upon its greater or less degree of adaptability depends the amount of conscious satisfaction which it derives from the use of its faculties - or, in other words, from its conscious life. $\dagger$ The experience of this satisfaction from right adjustment, and of the pains consequent upon mal-adjustment, has been the immediate motivepower in effecting social and moral evolution. The higher organisms are doubtless susceptible of greater pain and suffering than the lower; but this must be more than counterbalanced, on the whole, by an increase of satisfactions, or the life of the individual and the race would come to an end. The suffering to which conscious beings are subjected is not, therefore, an essential quality of life; it is the result of some interference with its spontaneous and perfect manifestation. Life itself, in its essential quality, is good. All organisms, consciously or unconsciously, seek instinctively or voluntarily for more abundant life, and find their health and satisfaction in its achievement. Conscions volition, in this particular, simply follows the path made for it by the inherited sum total of past involuntary and unconscious experiences. It testifies to the immanence in the organism of a universal biological law.

It naturally follows that those actions which tend to adapt the organism to its environment, though they may at first be attended with pain, and clemand effor't or self-denial, and are perhaps initiated only by reason of the imperative

\footnotetext{
* Spencer's Principles of Psychology.

† "Life" is defined by Mr. Spencer as " the continuous adjustment of internal relations to external relations" (Principles of Psychology). This expression is synonymous with the one we liave used - "the adaptation of the organism to the environment." Life is adjustment, or adaptation, involving a movement or process, tending toward a condition of harmony or equilibrium between tlie organism and the totality of its environing conditions.
} 
necessity for self-sustenance or race-maintenance, yield greater and greater satisfactions as they become habitual and instinctive. It is entirely natural according to this principle, that altruistic actions, originally initiated from egoistic motives, should be continued, when they become habitual, from higher motives. The original selfish impulse of desire or fear may be wholly eliminated, and the action may be pursued without thought of ulterior recompense. The child at first shares its playthings with its little companions, perhaps, under the stress of paternal compulsion; but it soon comes to receive pleasure from the perception and sympathetic appreciation of their pleasure: the generous act brings its own reward. 'Thus habit, in adapting man to his social enviromment, revolutionizes his ethical point of view.

Not only does it induce this change of conscious motive; it also differentiates the sense of moral obligation from those peremptory selfish instincts in which it has its root, thus creating the imperative impulse of Duty. "The "ought" of the Evolution philosophy having been evolved out of the struggle for a larger life, implies the obligation to strive for fulness of life in one's self and in the world at large.* For the service of Self, it substitutes the service of Humanity. It is more than an impulse to seek one's own immediate or proximate advantage and happiness. Interpreted even in egoistic terms, it implies an obligation to seek for the perfection of self, $\uparrow$ including the perfection of one's moral and spiritual nature; and to seek it, if need be, therefore, at the sacrifice of one's immediate personal comfort and happiness. Life is measured, ethically, not by length of years, not even by the present or proximate sum total of the individual activities; but rather by the sum total of the individual's influence in promoting fulness of life in all sentient creatures - now living and yet to be. The conception of moral obligation presented by the new ethics thus accounts for the action of the world's sages, saviours and moral heroes - for that of men like Socrates, Jesus and the Buddha - as well as for that of the conventional well-disposed citizen of the well-ordered State; for there are times when the clear vision of noble souls perceives that only by contempt for the conventional, by the overthrow of institutions which have become barriers in the path of human progress, can

\footnotetext{
*Fiske's Cosmic Philosophy. † Maude's The Foundation of Ethics.
} 
the perfection of the race be achieved. When such a conviction is clearly held by a strong and well-balanced mind, it can do no otherwise than seek the perfection of its own manhood through intelligent and devoted service to the welfare of mankind. Not to follow the imperative mandate of duty, even if it lead to contumely and death, would paralyze the life with a sense of ignoble shame.

Such is the history, in brief, of the evolution of morals such the facts which underlie the foundations of moral science. 'Throughout the ages since man emerged from the bruteegoism of his original estate, diverse human motives and activities have been pitted against one another in a struggle for existence similar to that which has gone on in the lower range of biological development. The same law has held good in moral evolution which justified the method of nature on the lower plane-the fittest in action has survived. 'Those motives, impulses, desires, which best fit man for the rational use of all his faculties, and which best serve the race in its struggle toward a condition of social equilibrium, have gradually emerged, and become not indeed actually triumphant over all lower impulses, but at least of generally recognized authority among intelligent people. The law of conflict, which seemed fraught only with pain, destruction, and the perpetuity of egoistic tendencies in the government of human conduct, blossoms at last with the noblest flowers of unselfish character.

It now remains for us to consider the nature of the ethical system which logically results from the facts of moral evolution, and some of the objections which have been raised against it. As the principle of utility, in a high sense, has. determined the selection or rejection of motives and activities throughout the entire process of moral evolution, it naturally follows that the Science of Morals should be classed as a utilitarian system. That it differs radically, however, from the crude utilitarianism of the older schools. is evident from our previous discussion, and will be still farther evident upon consideration.

Moral Science treats of the conduct of man in his relations to other men and to society in general. The order of moral evolution, and the laws governing it, are registered in the history and experience of the race. Its sanctions have been universally operative, alike upon the ethically wise and the ethically ignorant, thus educating all to a knowledge of the 
imperative nature of its demands. Its result is organized as conscience in the mind of the individual. Conscience, therefore, is the individual's inheritance of the moral experiences and tendencies of all past generations; it is not merely the creation of the existing social status. Prevailing customs, ideas, and institutions may influence the form of its immediate manifestations, - they do not account for its fundamental character as an imperative obligation urging man to an ideal end. Conscience appears in the individual as an intuition; but like all other intuitions it is the outgrowth of inherited experiences. It is of variant force and reliability in different individuals, dependent upon circumstances of organization and culture. In so far as it is actively existent, it urges man always to do the right, leaving his intellect, however, to determine what the concrete light is in any special emergency. It is not true, therefore, that conscience is an infallible guide, in the unqualified sense assumed by the transcendental moralist. The nature of actions as good or bad can only be determined by an observation and estimation of their effects. Morality therefore involves an action of the intellect as well as of the feelings; it holds man responsible for the intelligent investigation of the results of actions, as well as for the vague intention to do right.

Moral Science asserts that the qualities of actions are not accidental or arbitrarily determined by the will of Deity. They are "necessary consequences of the constitution of things." * By the study, therefore, of the laws of life, and of liuman conduct as related thereto, we may ascertain what kinds of action necessarily extend the boundaries and satisfactions of life, in the individual and in the community, and what kinds produce a contrary effect. These deductions, when ascertained, are recognized as laws of conduct, and the educated conscience is impelled to conform to these laws irrespective of any direct estimation of resultant happiness or misery. Thus the crude utilitarianism of the older schools is superseded by the rational utilitarianism of the evolution philosophy. Obedience to the moral law becomes the object and incentive of the highest intelligence, in place of the empirical impulse of immediate utility or egoistic pleasure.

Moral Science as thus described embodies the truths * Spencer's Data of Ethics. 
while it discards the errors of conflicting ethical systems. It recognizes alike the intuitional and the experiential nature of conscience; it is an intuition in the individual resulting from experience in the race. Conceiving of Deity as the Power immanent in all the processes of evolution,as immediately manifested in the nature of things, - and of ethical endeavor as the action of human volition in the effort to achieve harmony with this evolutionary tendency in nature and society, it recognizes also an underlying truth in the conception that moral action is obedience to the divine will. The obedience, however, is not to a testamentary will of God, made known in a verbal revelation, but to his actual will, revealed in the instant operation of natural and universal laws. "Fulness of life" is only another term for that "perfection or excellence of nature" which yet another school of thinkers regards as the ultimate object of moral action. Rising above empirical utilitarianism, the conclusions of Moral Science harmonize with the conception that Virtue, not egoistic pleasure, should be the object of ethical endeavor; yet it recognizes also that happiness is the natural concomitant of that perfection of life which all virtuous activities have in view, and is therefore in one sense the end, though it cannot be the immediate object of pursuit, in the perfect life.*

Deducing its system from the actual facts involved in the evolution of conduct, Moral Science recognizes both an absolute ethic, adapted to the perfect man in an ideal state of society, and a relative ethic, applicable to all men in each successive stage of social evolution. In many of the affairs of life there is fortunately for us no conflict between these two standards of judgment. In the relations of the well-ordered family, for example, all natural individual activities should be promotive of reciprocal satisfactions which tend to the completion of each individual life. Mutual service should bring mutual reward and happiness. The subject of ethics, however, in its total scope, is a very complex one. It is easy to turn a syllogism; it is not so easy, always, to decide what is right in the multifarious situations of life. Many of the problems of practical affairs are incapable of solution by the application of the simple tests required by an ideal standard of perfect conduct. A recent writer in the Fortnightly Review has treated of "The Ethics 
of Cannibalism"; and it may be admitted that he has fairly demonstrated that this social eustom is not so wholly divorced from ethical considerations as might at first appear. The system of slavery, which, as related to our modern civilization, was rightly denounced by John Wesley as " the sum of all villanies," was, in its inception, a beneficent substitute for slaughter and cannibalism, and its adoption indicated an ethical advance on the part of its originators. In many of the situations of life as they arise in the course of social evolution, under the pressing exigencies of contemporary custom, business competition, governmental regulation and popular prejudice, it must be recognized that the best that the conscientious individual can do is to choose that course of conduct which, under all the circumstances, seems likely to be productive of the fewest evil results, instead of that which is absolutely right, even if he is capable of comprehending the absolute right. A man who, in the midst of a savage or barbarous community, in defiance of current social or religious customs, should attempt to live the ideal life of a perfect civilization, would doubtless quickly be eliminated from such a society by violent and tragical means, and thus effectively be estopped from influencing those around him to better ways of living. Much of our enforced civilization of savage races has been fatal in its effects upon the health and happiness of the vast majority, while it has failed to elevate the average morals of the survivors. This is likely to be the result whenever conventional education is forced upon a people in advance of their functional development. 'The Hawaian Islanders offer' a fruitful and impressive example of the truth of this assertion, if such be needed. Even in our modern civilized communities he who attempts to live a life of ideal moral perfection will often "find himself in sufficiently dramatic situations." * He must be a very strong and well-balanced man who can materially aid society by violently and radically opposing its conventional methods and tendencies. The gradual evolutionary processes of ethical culture are usually more effective in bringing about social reforms, than "rumning a-muck" against social evils with violent denunciation and abuse.

The ultimate practical test of Moral Science in doubtful emergencies, when formulated, is nevertheless precisely 
what it would be in an ideally perfect society: That course of conduct must be adopted which will promote the greatest possible development of life-giving energies, both in the individuals immediately affected, and in society at large, including the life of posterity. Such action, wisely followed after a clue consideration of all attendant circumstances, will always satisfy the demands of an enlightened conscience. It must be remembered, however, that the absolute standard of right should always be held in view; and that no deviation from it is ever justifiable in one who is capable of apprehending such a standard, unless it clearly appears that any other course of action would diminish the sum total of life-giving activities in the world at large.

Moral Science, as thus described, holds in just perspective the claims of both altruism and egoism in their relation to conduct. The primary instinct of self-preservation which lies at the foundation of moral evolution, is ethically justified when pruned of undue selfishness, and held in proper adjustment and equilibrium with the general wellbeing. Man's first duty to society is to render himself an independent and self-supporting member thereof, and to qualify himself by the cultivation of his faculties for the intelligent and useful service of mankind. The exercise of all his natural functions and faculties, in due proportion, is to be regarded as a moral obligation, since by repeated neglect or disuse the organism is weakened, and thereby rendered less competent to add to the sum total of life-giving energies, both personal and social. For a like reason, all excesses are to be condemned and avoided _ including excesses of self-renunciation in altruistic service. Care of the body, the preservation of physical health, thus becomes a moral obligation. It cannot be doubted that in a more perfect state of society the confession of disease will become as shameful as the admission of moral delinquency. Even unavoidable invalidism, other than that which is the natural accompaniment of age, will be placed upon a par with inherited and ineradicable tendencies to moral lapse, like kleptomania and dipsomania.

Right thought, conscientious investigation of intellectual problems, is also enjoined by Moral Science. The moral man will cease to be an intellectual parasite, and form his own intelligent judgments on all the problems of thought. Thus only can the highest life be attained. The scope of 
ethics is wonderfully broadened by the application of the tests required by evolutionary morals. Right action is no mere concern of conventional morality, - an obedience to the "Thou shalt nots" of the formal code. It becomes a matter of positive, all-comprehensive and enduring obligation, inspiring the mind to purity, activity and integrity of thought as well as of deed - to nobility of motive, intelligent and conscientious regard for the possible results of action, and a sublime self-consecration to the interests, welfare and happiness of all sentient creatures. 'The fulness of life which is the end of ethical endeavor being the result of conduct in its ultimate stage of evolution, there will be no conflict between the wisest egoistic and the wisest altruistic endeavor in the perfect life of society, as governed by an ideal moral standard. In wisely seeking the perfection of self, we are seeking the welfare and happiness of others, and vice versa.* 'The new ethics thus cultivates and justifies a manly self-respect instead of the abject self-abnegation demanded by the old theological dogma of total depravity. "Self-love," it affirms with Shakspeare, "is not so vile a sin as self-neglecting." This attitude is not so widely separated as may at first appear from the ethics of the Sermon on the Mount, for the obligations implied by the beatitudes and the Golden Rule also find their sanctions and equipoise in self-interest.

The intuitive moralist finds an insuperable objection to the evolutionary theory of morals, in the fact that its sense of duty is derived. Duty, he says, is an original endowment of the human mind - a primitive and imperative intuition. Kant, however, the noblest thinker of the transcendental school, admits that the moral imperative is merely formal; it simply says we ought, withont declaring what we ought to do. It tells us that duty exists, but it does not tell us what duty is in any given case. "The only objects of practical reason," says Kant, "are therefore those of good or evil; but it depends upon experience to find what is good or evil." $\dagger$ An obligation empty of content is evidently no infallible guide to right action; and it is difficult. to see what advantage the intuitive moralist has over the evolutionist as to the strength of his ethical sanctions, since both theories admit that the sense of obligation is intuitive in the individual, and both derive the moral content from

* Maude's The Foundation of Ethics. †Kant's Critique of Practical Reason. 
the lessons of experience. 'The recognition of the derivative character of duty, however, as interpreted by legitimate inferences from the study of the evolution of morals, would appear to strengthen rather than to weaken its imperative nature, since it thus appears that the sense of obligation is derived from the essential nature of things - the very constitution of the universe. Duty is derived only as man and all his faculties are derived. It appears in the human mind as the culmination of the entire process of evolution. All living things, all worlds, the Infinite Power which is revealed in all phenomenal-manifestations, have striven to build up this imperative impulse in the mind of man. It is the latest and finest product of evolutionary labor, and necessarily, therefore, a supreme obligation to him in whose mind it has developed, until its behests are completely organized in his being. Then obligation ceases, only to give place to pleasurable instinct; and right action becomes as natural as the blossoming of flowers or the silent, resistless operation of the law of gravity. To be consistent, the intuitionist is compelled to deny that spontaneous right-action, pleasurably anticipated, and unaccompanied by a sense of compulsion, possesses any moral value whatever. The advocates of this theory are so earnest in affirming that a sense of duty and of the difficulty of doing right are essential to morality, that one might naturally infer that they must be personally conscious of heinous moral guilt, and suffering therefor the pangs of remorse. They would doubtless resent the personal inference, however, as energetically as does the sleek devotee of the revival meeting, who denounces himself, in a Pickwickian sense, as the vilest of sinners. Moral spasms and paroxysms of self-condemnation illustrate not only an immature stage of moral development in the subject, but also an immature phase of thought concerning the nature and sanctions of morality. Kant's definition of Duty as "necessitation to an end which is unwillingly adopted," certainly justifies us in cherishing Spencer's hope that pleasurable spontaneity in right action will ultimately supersede the sense of obligation.* Happy and willing obedience to the moral law would certainly seem to indicate a higher condition of ethical health than the compulsory and unwilling performance of moral obligations; and the self-respect implied in such oberlience is ethically a nobler

\footnotetext{
* Spencer"s Ethics of Kint. See also, Data of Ethics.
} 
and more helpful state of mind than remorseful self-depreciation. "Do not waste time in compunctions," said the Concord seer, in the spirit of the New Ethics. Longfellow's "Let the dead past bury its dead," phrases the same high thought: this is the nobler inspiration of evolutionary morals.

Praise and blame are indeed justly apportioned to individuals according to the degree of difficulty under which they pursue right courses of action; but the moral law is ultimately concerned with something infinitely higher than the task of justly awarding praise and blame for individual actions. Its purpose is the development of the highest life, both in the individual and in the social organism. When it has achieved this result in the individual as far as it is possible, by his conversion to pleasurable and voluntary right action, shall it be said that it is no longer operative in his life? Let it rather be recognized that therein it is completely operative.

Another objection often raised against the evolutionary ethics, is that it fails to recognize the freedom of the will. In this freedom, it is said, resides the sole opportunity for moral action. In the light of the facts of moral development, the conception of uncaused volition in man is evidently untenable. This conception, indeed, has no logical foundation in theory, save as it is connected with some hypothesis of a pre-existent will or ego - and of this we have no evidence in nature, nor in the observed facts of a rational psychology. The names of eminent thinkers of the metaphysical school may indeed be marshalled in the support of this dogma - Bruno, Leibniz, Rosmini-Serbati, Kant, Lötze and others, as well as the Oriental sages of this and by-gone generations; but it is a doctrine evidently manufactured to sustain certain metaphysical assumptions concerning the nature of the soul and conscience, rather than a conclusion deduced from the scientific examination of man's mental constitution, unbiased by metaphysical pre-judgments. It is contradicted by the unquestioned facts of heredity, and by all the accessible data of a rational psychology. Kant. rests his doctrine of moral responsibility upon the assumption of a pre-existent will - thus making the individual man rather than his parents, ancestors or the circumstances of his environment responsible for his nature. He admits, however, that man is free to act only in accordance with 
his nature. "All human actions," he says, "are determined according to the order of Nature by the empirical character and the co-operating conditions." From a knowledge of these, he admits, "they might be foretold with certainty, and necessarily deduced." He thus practically recognizes the operation of cause and effect in human action. The conception of the will as an entity, apart from and superior to the mental faculties, has no foundation, however, in the observed phenomena of mind which constitute the data of mental and moral science. Moreover, as the sanctions of evolutionary ethies inhere in the nature of things, they operate on all minds, irrespective of their theoretical judgments. Hence, the importance of belief in the freedom of the will seems to be greatly over-estimated by its advocates.

The will, as defined and recognized by the new ethics, is an inseparable element in all conscious adaptations of acts to ends. "Will, or volition," says Bain," "comprises all the actions of human beings, in so far as guided by feelings." * "Volition," says John Fiske, more tersely, "is the process whereby feeling initiates action. * * The will is not an entity, but a dynamic process." $\dagger$ It is therefore, as Dr. Eccles has pointed out, an element not only in human conduct, but in the conscious activities of all sentient creatures - even the lowest. Human volition, in all sane minds, is determined by rational and ascertainable motives; and herein lie the chief means and incentives to man's moral regeneration. A new thought projected into the mind, a new point of view held up as a mirror in which man may regard the tendencies and results of his actions, may become the all-powerful motive leading to a revolution of conduct. All our educational systems, all wise penal and reformatory methods, are based upon the belief that normally constituted minds will inevitably respond to certain motives by corresponding and predicable lines of action. Nature herself, indeed, appears to have acted in accordance with this understanding, throughout the entire course of moral evolution; and thus man has been led onward and upward out of brute-egoism toward the ideal of a perfect manhood. Man but endeavors, in the range of the moral activities, to substitute for the slow process of natural selection, the quicker appeal to intelligent selection by means of legislative enactments, education, and volitional effort. In the

\footnotetext{
* Bain's Moral Science. † Iriske's Cosmic Philosophy.
} 
natural and causal sequence of motive and action, and the relation of motives to their logical antecedents in thought, we note the only possible conditions for improving man's moral nature.

Is human conduct therefore necessitated? Yes: but by the nature of man's own being - by no external force; and this nature is therefore largely, though not exclusively, of his own making. The motives which govern his action are a part of his essential being. He necessitates himself, which is only another way of saying that he acts as he freely wills to act. In obedience to law, in voluntary conformity to the nature of things, he finds the only possible reality and exercise of freedom. Having arrived at an intelligent conception of the laws of conduct, of the end and logical results of his voluntary actions, he is no mere automaton or machine played upon by external forces. He has developed a genuine, though limited autonomy, and may justly be held responsible for his moral conduct.

Kant sees nothing but pure determination in the conception of conduct as governed by motives. He compares it to the action of a balance and its weights. Professor Schurman thus aptly replies to his argument: "Whoever reflects that a motive is merely an idea, and that an idea has no existence apart from the subject that has it, must object to the comparison of a man and his motives to a balance and its weights. The former is merely an ideal, the latter a real duality. Man is nothing apart from his icleas; but the weights and balance have each an independent existence. 'Thus, volition, or willing according to motives, is by no means a necessitation. And it was here that Kant failed to see the full significance of his fundamental notion, while contending for an empty shadow which was scarcely the ghost of a living freedom. If freedom be not found in our volition with motives and not without them, it dwells not with man, it is nowhere to be found." * Man's conduct being necessitated from within, not from without, under the law of motive, he has, if we mistake not, a real freedom of action, though it is something quite different from the uncaused volition which is assumed by the advocates of the doctrine that the will is a pre-existent entity.

A fine reconciliation of intuitional with utilitarian ethics is discoverable in the perception of the identity in charac-

* Schurman's Kantian Ethics, and the Ethics of Evolution. 
ter of the moral law with all natural laws, and the logical inference that though discovered inductively and through experience, it is miversal in its scope and operation, mlimited by social conventions or individuai intelligence. As the law of gravity operated eternally before its discovery and definition by Newton, so the condition of things expressed by the moral imperative has operated during the entire course of human history and biological evolution. The scientific law of conduct is found to be the statement of a fundamental and a priori condition of the highest development of individual character and social activities. The impulse to right action appears in truth as a "categrorical imperative," not alone in the conscionsness of man, but in the constitution of the universe - operating in man to create the individual conscience, and everywhere revealing itself as the condition precedent to all social and moral advancement, on which individual character and harmonious communities depend. "The rule of right, the symmetries of character, the requirements of perfection, are no provincialisms of this planet: they are known among the stars; they reign beyond Orion and the Sonthern Cross; they are wherever the Universal Spirit is; and no subject-mind, though it fly on one track forever, can escape beyond their bounds." *

As all moral acts are life-promoting acts, it is the essential nature of immorality to be destructive - suicidal. The penalty of evil conduct is the instant and immediate atrophy of character; if persisted in, it is both moral and physical death. Salvation, therefore, is rationally identical with character-building; but character means more than mere goodness; it means fulness of life,_the cultivation of every mauly and womanly faculty, - the devotion of the life to human welfare.

Evolutionary ethics respects the individual. It makes perfection of individual character the supreme end, seeing that thus only can society be perfected. Society is indeed regarded as an organism, $\uparrow$ but the individual is to society

* Mirtincau's A Study of Religion.

$\uparrow$ The social organism differs from the lower forms of organic life in an important particular: - in the latter, the cell, or unit, appears to exist for the sake of the organism; while in the former, the organism appears to exist for the sake of the individual or mit. In all organismis, however, the perfection of cell-life appears to go along with the perfection of the organic structure. The resemblances letween social and organic growth seem to be sufficiently striking to justify the use of the term "social organism." 
what the cell is to vital tissue: the more perfect the cell, the healthier is the tissue. Obliterate the individuality of the cell, and all high organization is impossible. 'The communistic idea would subordinate the individual to society, - to humanity in general. It would sacrifice the living man to an abstraction. The ultimate tendency of this ideal is toward the obliteration of individuality - the establishment of homogeneity of character and intellect, the fossilization of social instincts and activities through individual conformity and inactivity, thus defeating its avowed end and aim. This tendency is opposed to the entire trend of evolution, which constantly tends to differentiation, heterogeneity, individualism, progress. Whenever the communistic ideal becomes dominant, society is arrested in its development or hastens to decay. Communism is the sure precursor of social disintegration and death; it is a reversion to the earliest social status of uncivilized man. After communism, by a natural reaction, comes anarchy; and anarchy lived out is social dissolution. This result can only be prevented by respect for the rights and personality of the individual, and respect by the individual for the laws of conduct as determined by the science of morals. Voluntary co-operation instead of legislative communism constitutes the social icleal prophetically outlined by the study of the principles. underlying the entire process of ethical and social evolution. The liberation of the individual - his increasing freedom to secure the satisfactions consequent upon the natural and harmonious use of all his faculties - proceeds pari passu with an increasing dependence on society in general. Thus society integrates by a natural process of growth, forming a real brotherhood of consent, instead of a militant organization, consolidated by external coercion. The condition of society involved in this ideal is one in which each individual shall have full opportunity for the development of his whole nature, and to which each shall freely contribute his noblest and most conscientious service.

Among the hills of old Berkshire, there is a noble birch tree, gigantic in trunk and limb, and abundant in foliage, which towers above its neighboring companions, but grows, apparently, out of an immense granite bowlder which was deposited centuries ago, where it now rests, by the action of a mighty glacier whose resistless energy had borne it from some far-away mountain summit. Beneath the rock the 
earliest tiny rootlets of the tree found soil and nourishment: its first tender shoot sprung up into some small crevice in the great bowlder above them. Here, one might think, it would have paused, submitting to the adamantine pressure, either crushed utterly to the earth, or dwarfed and deformed by its unyielding enviromment. But it had the irresistable evolutionary forces of Nature behind it; the sunlight above wooed it from its prison-house - it pushed upward toward the light. Gradually the little crevice in the rock was widened, the great bowlder was split asunder as by the hanmer of Thor, - the noble tree, scarcely distorted by the struggle, protected from destructive storms by its conquered enemy, grew with the years, and spread abroad on every side its leafy beanty and the blessing of its grateful shade. So conscience - the moral sense - a little germ at first, inclosed in the hard shell of the natural instincts, struggling against the mighty bowlder of animalism, has at last split the obstacle in twain, and emerged to bless the world and justify the method which has given it birth. And the Infinite Energy, one in the misty nebula and the glowing sum, in rock and tree and animal, and in the mind and conscience of man, "saw everything that it had made, and behold, it was very good." 


\section{ABSTRACT OF THE DISCUSSION.}

\section{Professor Thomas Davidsor:-}

The fact that I was invited to open this discussion with the full knowledge that the frankest dissent might be expected of me, indicates a high degree of moral evolution on the part of the managers of this course of lectures. The limited time, however, places me at a disadvantage, speaking as I do to an audience made up of those who agree with the able lecture of Dr. Janes. I object not so much to the observed facts of Evolution, as to its theory about them. I object to the presupposition that there is no knowledge outside of experience. Man's aim, according to the evolution philosophy, is to serve an abstract humanity, without any reward therefor. Evolution, the lecturer declares, is a tendency which has been observed in Nature - a purposeful tendency - a tendency to "fulness of life." The lecturer, however, has failed to define what life is. The assumption that there is no knowledge outside of experience is not due to evolutionary thought, but to a negation of thought. The effort to erect a philosophy on this basis is due to a reactionary impulse in thought which must be short lived. Evolutionists declare that there are three stages in the development of thought, the theologic, the metaphysical and the scientific. One would think that the metaphysical stage, being so much in advance of the theological, would be treated with respect, but on the contrary it is treated with contempt and abuse. John Stuart Mill, who was a devoted adherent of this philosophy, was one of a class whom we may call "metaphysical-phobists." Now, metaphysics is in bad repute principally on account of the shallowness of thought and narrowness of reading of these metaphysical-phobists who are now so popular. Evolutionists know nothing of metaplysics. What do they know of Aristotle, of the Neo-Platonists, of Thomas Aquinas? We do not get all our own knowledge from experience. The assertion that we know nothing of the spiritual which is not revealed in experience is due to pure prejudice. Dr. Janes indeed speaks of a "Universal Spirit" with a purpose, and this is essentially a theological conception. And this "fulness of life," - what does it mean? Does it mean the maintenance of all life - the life of "all sentient creatures," or of 
man only? What are we to do with the gnats and mosquitoes, forinstance? "Fulness of life" is a very vague phrase for a summum bonum. In mere mechanism there is no tendency either to good or evil. 'Then, according to this philosophy, the moment this tendency gets where it can be of use, the moment it gets into life, it. errs. "Fulness of life" is defined as "subjective satisfaction." But animals have no morality, yet they seek this satisfaction. Carnivorous animals destroy "fulness of life" in seeking this satisfaction. Only the satisfaction of intelligence, without reference to pleasure, shows the moral. Evolution puts the cart before the horse. The moral sense inherent in the constitution of man has. developed morality, not physical changes and social necessities. If environment produces morality, why are not animals moral? It is the fundamental moral faculty that is the cause of moral development.

\section{Rev. Jorn W. CHadwick:-}

I am surprised at Professor Davidson's torrent of negation. I had hoped that he would give some reasons for the faith that is in him. I will not speak at length in reply to his statements, from which I dissent, preferring to give as much time as possible to $\mathrm{Dr}$. Janes.

\section{Mr. Thomas Gardner:-}

I find myself thoroughly in accord with Dr. Janes in his treatment of this question. I cannot understand how an intelligent man can ascribe the rejection of the metaphysical philosophy, by leading scientific men, to their ignorance of the literature of that school of thougint. Certainly Spencer and Huxley, and others of the Evolution school, have shown abundant knowledge of metaphysics. If I were to criticise Dr.Janes's able paper, it 'would be in that he has omitted the admiration of the heroic and the love of the beantiful in considering the influences which led to the evolution of morals. These influences were of great importance, it appears to me.

\section{Mr. Nelson J. Gates:-}

I regret that Professor Davidson made no definite affirmations. in expressing his dissent from Dr. Janes's paper. Evolution holds. that morals are developed from within, from the very constiution of things. But all ethical theories must be tested by experience. The theory of the Sermon on the Mount was evolved from a consideration of the static relations of luman society, but it has beem 
rejected by experience. Take, for example, the command, "Whosoever shall smite thee on the right cheek, turn to him the other also." We all agree in rejecting such a rule as impracticable.

\section{Professor P. H. VAN DER WEYde:-}

Professor Davidson has said that evolutionists are ignorant of metaphysics, but it is my experience that metaphysicians are all ignorant of the simplest principles of physics. Now it seems to me that metaphysics must be based on physics. The material world should be the first subject of study, but this is neglected by metaphysicians, who are far more open to the charge of ignorance of physics than are the scientists to the charge of want of knowledge of metaphysics.

\section{Dr. Robert G. Eccles:-}

Professor Davidson declares that evolutionists have metaphysical-phobia; but he has evidently come in contact with Comteists rather than with Spencerians. Evolution has no contempt for metaphysics. On the contrary, it admits a measure of truth in all systems of thought, and desires to harmonize the truths of varying systems into a synthetic philosophy. Professor Davidson cannot getback of phenomena, nor can any metaphysician, however boldly he may proclaim his ability to do so. The "fulness of life," which he criticises, means adjustment; it means the perfection or correspondence between inner relations and outer relations, between organization and environment.

\section{DR. JANES:-}

I regard it as a high compliment to be criticised by Professor Davidson, one of the ablest metaphysicians, without doubt, in this country. And if his criticism has taken the form, mainly, of unverified assertion and barren negation, its weakness is a defect in the method of metaphysics, not in the man. Evolution, as Dr. Eccles has said, recognizes that all systems of thought contain some truth, and explains also why this must be so. The human mind can but reflect, in some degree, the truth of that Universe out of which it has been evolved. Metaphysical assumption, however, should be verified by experiential tests. Since all thought is a part of experience, I confess I am unable to see how we can have any extra-experiential knowledge. It seems to me that my critic descended from his usual high plane of thought in raising the questions about gnats, mosquitoes and carnivorous animals. I think the principle which I laid down is clear to all unprejudiced 
minds: we are bound to preserve and sustain life in all creatures. which do not interfere with or detract from fulness of life in the totality of things - taking into account, of course, the quality of life as judged by an evolutionary standard. This law makes it. our duty to destroy those creatures which impede human advancement, as it is our duty to exercise protection and kindness toward our poor relations of the animal world, who are helpers of mankind. Animals, indeed, are not moral, as I have declared. Neither was primitive man. But animals are on the road toward the moral. The moral is but man's self-conscious recognition of laws. that reach all the way down, through the brute to inanimate nature. I fail to see that the moral sense is in any way discredited by being explained, as the intuitionalists assume. The evolutionary sanctions of morality seem to me quite as imperative as those of the metaphysicians. 


\section{PROOFS OF EVOLUTION}

BY

NELSON C. PARSHALL 


\section{COLLATERAL READINGS SUGGESTED}

IN CONNECTION WITH ESSAY XII.

Darwin's Origin of Species; Haeckel's History of Creation, and Evolution of Man; Spencer's Biology; Fiske's Cosmic Philosophy and Excursions of an Evolutionist; Huxley's Letters on Evolution and Critiques and Addresses; Romanes' Scientific Evidences of Organic Evolution; Wallace and Dyer's The Distribution of Life; Schmidt's Doctrine of Descent and Darwinism; Cazelle's Outline of the Evolution Philosophyy; Professor Morse's Presidential Address before the American Association for the Advancement of Science, 1887. 


\section{PROOFS OF EVOLUTION.*}

Emerson says: "Beware when the great God lets loose a thinker on this planet. 'Then all things are at risk." This laconic saying has been more than verified within the last thirty years. The thinkers have been holding high carnival; - and all about a little protoplasmic cell that none of them could see with the naked eye.

Two great questions have always been before the world: one, as to the beginning of all things; the other, as to the end of all things. Concerning these two problems, many sacred books have been written, from which a dozen great religious systems have sprung, all setting forth, more or less minutely, theories of the genesis of mind and matter. The explanations thus given, though crude and barbarous in many of their features, have been generally accepted, and the races of men have shaped their earthly careers in accordance therewith. Now and then a splendid soul arose and denied the truth of these assumed revelations; but he rarely lived to repeat the denial.

For ages men were content merely to know how to utilize the simplest forces of nature, to learn how to do the commonest things, and to join in communities for pleasure and protection. They thought all things were made out of hand by a Supreme Architect who directed momentarily and minutely all human affairs. Fear and wonder made all their gods, and love and hope supplied them with the beautiful belief in immortality.

Although the martyrs of truth fell one by one, each left a germinal thought behind. Only within the present generation has it become safe and reputable to think. Hardly is this even now the exact truth ; for the "Descent of Man" was at first hailed with good natured laughter and gentle derision; it was a good drawing-room joke at the expense of the monkey tribe. Even at the present moment, the vast majority of the people smile broadly whenever the subject

* Copyright, 1889, by The New Ideal Publishing Co. 
of man's evolutionary origin is seriously mentioned. Comparatively few as yet accept all that is implied in the doctrine of Evolution. Nevertheless, it is bound up in one way or other with nearly every branch of human knowledge. The word is in every mouth. The fact connects itself with every known phenomenon. The greatest foe to the development theory has naturally been the church; because if Evolution is true, theology must be reconstructed in accordance with the principle of the supremacy of law and the impossibility of its violation by the intrusion of miracle. Not until there are more Scientific and Ethical Associations, and not until schools and colleges teach the doctrine of Evolution, will it become imbedded in the thought and life of the masses.

It may be, and often has been, asked, "Of what use is all this knowledge? What is the practical benefit of believing that man began life as a Moneron, and by strict at. tention to business has worked himself up to his present high estate - 'the paragon of animals'?" In the flrst place, all this is worth knowing for truth's own sake, since every truth contains the germ of good, and wherever it leads, all may safely follow. But the practical benefit which the knowledge of Evolution conveys, influences man in all relations of life, as an individual and as a member of society. First of all, it teaches him the great lesson of reliance upon law - that all things are the result of growth and development; that the present is the child of the past, the simple the germ of the complex. It teaches the impossibility of the fortuitous and the miraculous, - that if we expect effects, we must set in motion adequate causes; that to live wisely and well, we must adjust ourselves to the natural and rational.

While it does not take away one rational hope, Evolution sweeps into oblivion all the childish fables of the past; it points to a new heaven and a new earth; it bids us awake from our pretty dream of the supernatural, and work in, with and through Nature, if we would make the wilderness of woe and wrong to blossom as the rose. It has unified all science and given learning a new force and meaning. It has added vastly to the sum of knowledge, and to the aggregate of human happiness.

In all its branches and bearings, it directly tends to enlarge: and intensify human love and sympathy, and so stimulates. 
the forces that lead to industry and thrift, and on to the highest plane of moral well-being.

It teaches the principles of adjustment and harmony ; it bids us always to take thought for the morrow, and proclaims that love and labor united constitute the "divinity that shapes our ends." It will make the world more generous, kind, and charitable; more patient, brave and true; more humble, gentle, and unselfish; more noble, virtuous and patriotic. It will do all this because it asserts the great law of mutual duty. Evolution affirms the survival of the fittest. It prophesies even better things to come, than those which we now know. It points toward an ideal of perfection. Its flower and fruitage in life is moral grandeur.

Admitting its scope and possibilities, as thus portrayed, we are now at the threshold of the vital question, "Is Evolution true?" For nothing false can be a permanent good. 'This question must be answered briefly and imperfectly; for an hour gives time barely to mention the various phases of the great theme. We are compelled to take a hasty view of the broad field, touching only the mountain peaks in the line of proof which establishes the theory of Evolution.

What is Evolution? A late writer has tersely defined it as follows: "Evolution is continuous, progressive change, according to certain laws, and by means of resident forces." Evolution is simply growth and change, governed by fixed laws. Its corner stone is continuity.

The Essayists who have preceded me have explained to you Solar and Planetary Evolution, as also the Evolution of the Earth as a whole, of Vegetal and Animal Life, of Mind, of Man, of Society, Theology and Morals. It is in the field of Biology, however, that the proofs of Evolution are most abundant and conclusive. To this line of proof I shall mainly confine my attention. But before proceeding to details, it may be well to point out the

\section{FOUR GREAT FACTORS OF EVOLUTION,}

on which the entire theory rests. These are (1) The influence of Environment; (2) The increased use or disuse of organs; (3) Natural Selection, or Survival of the Fittest; and (4) Sexual Selection. The two former are accredited to Lamarck and others, but the two latter are wholly Darwinian; and running through all is the potent influence of heredity. 
A change in environment effects a corresponding change in functional activities, which leads to structural modification. Common observation and experience show us the effect of the use or disuse of an organ or part. This is likewise observable in determining the greater or less acuteness and activity of all the senses. An organ lying dormant during many generations will gradually atrophy, and appear as a rudiment, finally vanishing altogether. Fishes and animals dwelling in underground caves into which no light enters, are sightless, as they have no uise for eyes. They have lost them by disuse. The wonderful development of the gymnast and athlete is achieved by intensified use of the muscular system. If use or disuse is continued from generation to generation, heredity will transmit the result.

Natural Selection, or Survival of the Fittest, grows out of the struggle for self-preservation. It is based on the law of hunger. It develops strength, cunning, or agility. It is an enemy to the weak and poorly conditioned. We see this principle exemplified every day in the struggle for supremacy among individuals, communities, nations, and races. The strongest and best-favored survive; the weakest perish.

Sexual Selection is not concerned with hunger, but with beauty and the desire for offspring. As well stated by Prof. LeConte, "In Natural Selection there is a struggle of all for food, or means of living. In Sexual Selection there is a struggle among the males for the possession of the females and the means of procreation. The one is related to the nutritive appetite, the other, to the sexual appetite."

In animal life, Natural Selection most obtains among mammals; sexual selection is more predominant among birds, those having the most beautiful plumage, or sweetest songs, winning the choicest mates. The former fight for existence; the latter, like the warriors bold of the Middle Ages, battle for love. This warfare is in the world to-day wherever there are life and movement. These principles of evolution are still everywhere operating. Heredity preserves these jewels of descent, without which we would go back to "chaos and old night."

PLOOFS FROM (TEOLOGY.

Among the strongest proofs of Universal development, are those drawn from geological study. The earth has en- 
tombed all organic forms that have ever lived, and awaits the inevitable hour to receive all that live and breathe to-day. The process which everywhere goes on is one of evolution and revolution. Every disappearance is followed by a new form, readjusted upon a higher plane. The Earth is the Great Stone Book, giving us, as we turn the strataleaves, illuminated pictures in bas-relief of the life-forms of past ages. What a Revelation! written by the finger of 'Time on the rock of Ages, and by the ink of Death. Nothing can falsify the record. It is immutable, and antedates by millions of years the printed books of man, which assume, with much pomp and circumstance, to tell us all about the beginnings of things.

Geology finds in the lower strata of rocks, just what we might expect to see if evolution is true: First, only the lowest forms of animal life, and sea-weeds. Then, through later and later deposits, successively appear remains of fishes, reptiles, mammals, and finally man, together with all the varying forms of plant-life appropriate to the successive periods. Nor is this all. In many cases, intermediate forms between species have been found, - the "Missing Links" so often inquired for by the opponents of Evolution. Why all the generalized types are not found, is manifestly owing to the imperfection of the geological record, induced by the devastations of time; such as the action of heat and cold, and the convulsions of nature. Change is manifested everywhere, stability nowhere, except in the laws of universal causation. Form and substance are but puppets in the hands of one great master, Time.

Astronomy and Geology! twin liberators of the human mind,- one taught Infinite Space, the other Infinite Time. Before their birth was mental chaos. The popular theory of the heavens and earth was essentially mythological, like those of Greece and Rome, but shorn of all their wondrous beauty and refinement. Astronomy caught from dancing globes their laws of sustentation. Geology wrung from stubborn earth the jewels of her treasure-house.

PROOFS FROM MORPHOLOGY.

Convincing proofs of the truth of evolution are found in the homologies of animal structure. It may be well to distinguish this word, Homology, from Analogy, which refers to organs similar in form or function, but differing 
in origin, while Homology relates to those parts or organs which, however dissimilar in office, were derived from one and the same part, modified and readjusted by use. For example, the wing of a bird and the wing of a butterfly are analogous, since they are both used for flying; but they are not homologous, for they had not a common origin. But the wing of a bird, the fore-paw of a reptile or mammal, and the arm of a man, are homologous, since they have the same general structure, modified for different uses. Analogous parts look alike, but are not alike; while homologous parts may have little or no resemblance, but are in fact the same parts in disguise.

Morphology, or the science which describes the ideal forms or parts of organs, - the so-called structural "types" in living organisms, - runs throughout the entire animal and vegetable kingdoms. The structural evolution of one mammal is a type of the structural development of all. We will therefore select the horse, as at once the most beautiful and useful, needing only the gift of language to make him human. The beautiful form, color, size and structure of this animal were not fashioned at once, but have come to their present perfection through small and gradual changes extending back through vast periods of time. It has taken Nature ages and ages to make a horse, and she isn't done with him yet or he wouldn't balk and shy. The stockbreeders have joined hands with Nature and are rapidly improving his beauty, speed, and strength, while heredity is silently keeping the score.

From Geological discoveries we know that the horse came from a five-toed ancestor. In Europe, India and America he has been traced as far back as the early Eocene period, where he appeared no larger than a common fox. He then had three toes behind and four in front, with the rudiment of a fifth. Latex on, we find him increased to the size of a sheep, but minus the rudimentary toe. The next advance was to a three-toed animal all around, about the size of a yearling colt, with the rudiment of a fourth toe on each foot. This stage of his development was followed by a shortening up of the side toes, while the middle toe grew broader and stronger. Finally, in the Quarternary period, we have the modern horse as we see him to-day,the side-splints yet remaining, as rudiments, to tell of his long line of descent. 
What is true of the toes of the horse applies as well to the development of other parts of his structure. The principle applies not only to him, but to all living things. Descent with modification is a universal law. By the necessity of continually varying his modes of life, the horse has advanced from a useless little plantigrade quadruped to the position of the greatest help-mate of man, bearing patiently his many burdens and contributing in no small degree to his pleasure. But Evolution, which fashioned the horse and made him man's burden-bearer, is also raising up friendly inventors to emancipate him from some of his heavy toil.

All the organs, as well as all the parts of the skeletons of all animals, have undergone slow and gradual changes, flom the simplest beginnings up to their present complex state. New and ever-changing environments have brought corresponding modification of the organs or parts. Those no longer needful, shrunk to rudiments, finally disappeared altogether. Those needful and used were strengthened along their several lines of growth, until we have to-day all the wonders of form and function.

Nature never begins her work de novo, for her adaptive genius is so great that she can transform the old into the new. When she wanted to make a landsman of a fish, she did not give him a new pair of legs at once, but left him to utilize his fins for that purpose as best he could. Of course, he made bad work of it at first; but as he was left in the hard grip of necessity it was Hobson's choice. As he was often left on shallow, muddy shores by receding tides, he began to work his fins more vigorously, until finally, after many generations, in spite of a round of fatal failures, some of his kind succeeded in adapting their fins to this new use. The mud-fish of India, the Brazilian doras, and certain catfish of tropical America, take journeys of considerable length across the dry land in this way. Thus the swim-bladders of certain of the early fishes gradually developed into lungs, the gill-arches into ears; the head enlarged; the circulation increased; a warmer current filled the veins; the tail-fin, not having much to do, dwindled to an ornamental appendage, - and then and there a quadruped was born.

Again, when Nature wanted a bird, she didn't make one out of raw material, as we are told, full-winged to soar 
away, but "worked over" the old fabric, just as thrifty housewives do, and do so wondrously well. 'Therefore, if wings are needed, the fore-limbs must go - they must be transformed into wings. Ages pass on; the earth is filled with birds, beasts, and creeping things, but the quadruped is king. He has grown to enormous size and strength, and appears in almost endless varieties. 'The struggle for existence has preserved the strongest, the most cunning, and those most highly skilled in the art of food-getting. The fierce warfare through which all living creatures have passed, would naturally sharpen all the senses, and stimulate, little by little, the power to observe and discriminate as to friend and foe, and as to foods, and favoring localities. This would induce some sort of reflection, and implant in the mind at least a nebulous train of reason and ordered thought. 'This would give the brain more and better work to do, and the doing would increase its size, quality, and convolutions.

Why should advance stop at this point? Why should not the same progressive change and upward tendency still go on? Is the change from the mute little fish to a roaring Saurian less marvelous than the advance from highest mammal then existing to the earliest savage man, without speech, or language, and feeding on whatever prey the forest offered, including his own kind? Doubtless man lived thousands of year's before he acquired what we would now call ianguage. Nevertheless, his earliest cries and noises were the beginnings of connected speech; though no more intelligible than the chattering of apes.

If we could go back to this lowest conceivable savage, what should we find? Probably this: The anthropoid ape and the man-animal not quite out of sight of each other, but evolving on divergent roads from a common ancestor. If we could have stood near the diverging point, it would have been difficult to tell which had the potency of the dominant animal who rules the world to-day.

Most people who try to reason about the matter, make the mistake of attempting to bridge the chasm at once from Shakspeare to a shrimp; and they say the difference is so enormous that Evolution cannot be true. But the thoughtful student goes back step by step, age by age, until he stands side by side with a creature half upright and howling, with all the ferocious instincts of a brute, but yet 
man-like in form and function, his language a jumble of incoherent noises, his moral sense yet undeveloped, killing and eating all he could overpower. From this field of vision, we can see little difference between our potential man and his fellows of the forest.

Some will ask, and do ask: "At just what point and under what circumstances, did the direct line of man begin?" And, "If it occurred once, why may it not occur again in the myriads of life-forms continually appearing upon the earth?" To the first query the answer must be, there is no such point. Evolution is but a shading and a becoming. But there were certainly circumstances which led to the line of man, and these are not hard to imagine with the factors of evolution in view, and highly favoring conditions supeladded.

Let it be remembered that a rugged environment necessitating marked changes through the use or disuse of organs, together with the ever-continuing struggle for existence, perpetuating the strongest and best under the law of heredity, are the great forces in Morphological development.

Once more, let us go back to the common ancestors of Man and the Anthropoid, and watch these primitive children as they start out together, some in one direction, some in another, their dispersion extending over broad territories during thousands of years, until at last they find themselves in utterly dissimilar environments; the one condition unfavorable, the other highly favorable to progressive development. Let us suppose the favored ones found themselves in the midst of circumstances not requiring tree-climbing, either for food or for safety. Naturally, they would begin to use their fore-paws for food-gathering, and for throwing missiles at enemies. This habit would gradually throw the weight of the body more and more on the back-feet, leaving the arms and upper part of the body free for the various actions required. In time, adaptive changes would occur in the direction of an upright and flexible spine, and greater utility in the use of the arms. These changes, slight from generation to generation, in the aggregate would give us the hand of man, "which supplies all instruments, and gives him universal dominion." As Darwin remarks, "It accords with the principle of the division of physiological labor, which prevails throughout the animal kingdom, that, as the hands become perfected for prehension, the feet should 
have become perfected for support and locomotion." As these early man-animals went in herds and could utter cries, it is probable they soon learned to warn one another of the approach of danger, and also to express to one another their feelings and desires, which was doubtless the beginning of human speech.

There are those who, in the pride of intellect and reason, reject with contempt such a lowly origin. They prefer descent from disgraced perfection, rather than a steady ascent through all the lower forms. They accept the belief that their bodies were made out of hand, from a lump of local dust, and that they are to this hour undergoing a penalty of pain and labor for a sin committed by a very distant relative, rather than believe in ascending excellence from the very first. In short, they would rather be fallen angels than risen men.

On this point Mr. Darwin speaks as follows: "Unless we wilfully close our eyes, we may with our present knowledge, approximately recognize our parentage; nor need we be ashamed of it. The most humble organism is something higher than the inorganic dust under our feet; and no one with an unbiased mind can study any living creature, however humble, without being struck with enthusiasm at its marvelous structure and properties." Finally, it may be said that man is a product of all the ages, a summary of all evolutionary efforts, an epitome of all preceding life; he is literally "made up of a little of every creature's best," the crown and glory of cosmic energy.

\section{PROOFS FROM EMBRYOLOGY.}

Perhaps the most striking evidence of the truth of Evolution is found in the study of Embryology, which is the science of the embryonic cell. 'Three great stages of growth may here be noted, the cell, the inclividual, and the tribe. That all organic life has been evolved from primordial germcells during countless ages, is now the firm position of Science. Even the method and laws of growth have been clearly outlined. The microscopic ger'm-cell, when first stirred by the energy of life, subdivides, producing two primary germ-layers, - by fission again developing four secondary germ-layers, and so on. These new cells do not entirely separate, but remain in contact. From the continual aggregation of cell-forms, all the organs and parts of 
the body are developed. When an egg is formed by a multiplicity of cells, it separates into three distinct layers, called the ecto-blast, the endo-blast, and the meso-blast, from which are developed by differentiation the three great life-centres, namely, the nervous system, the nutritive system, and the blood system; and from these follow the multitudinous branchings to the highest stage of differentiation in the ontogenic series. Tracing any one of these groups, as the nervous system, we find it differentiates once more, forming the cerebro-spinal and ganglionic systems, each haring different functions. The cerebro-spinal again differentiates into two systems, the voluntary and reflex,- - these still again branching out into sensory and motor centres and fibres. The sensory-fibres branch out into the five senses with their separate functions. Take any one of the senses, as touch, and we observe that the nerve-fibres are not all alike. Some are sensitive to heat and cold; others to pressure. The nutritive and blood systems have, likewise, their special lines of differentiation, culminating in all the different organs, parts and functions of the animal body. And this is the process of every life and every birth.

One of the most startling as well as one of the strongest proofs of evolution, is found in the fact that in Embryonic growth, each incliviclual passes through all the successive stages which have preceded in the line of its tribal history. In other words, philogeny is repeated in ontogeny; the race in the individual. At a certain point, the embryo ceases to personate its ancestor's, and commences to take on the form peculiar to its own kind. Professor Haeckel, in his "Evolution of Man," has given a series of plates showing the development of the embryos of the fish, salamander, tortoise, chick, hog, calf, rabbit, and man. At certain stages in their pre-natal development, there is an exact resemblance of form among them all, each becoming specialized as it approaches the time of birth. At one period of its growth the human embryo has the long, free, swinging tail of the races below it.

Whither does all this array of facts lead? What explanation can the creationist give? If man was fashioned at once, why drag him to nativity through all the forms of the brute-creation? Why masquerade him in the guise of the dumb, ferocious, and soulless brutes? There is no 
reasonable explanation of these facts outside of the theory of development. There is no escape from the conclusion that man, and all mammals, have a common origin and a similar philogenic history. How strange and stirring is the thought. The changes of ages are compressed into the brief span of embryonic life!

\section{PROOFS FROM METAMORPHOSIS.}

Metamorphosis is closely allied to embryological development. In the latter the changes are all pre-natal; in the former, they continue after birth, - the transformations taking place before our very eyes. All are familiar with the common examples. The frog begins life as a fish; limbs grow, and lungs displace gills, as he passes on to the condition of a tailless croaker. Butterflies, bees and beetles start out as grubs, and undergo what wondrous transformations! The star-fish is first a swimming worm; the crab is born a tail-like shrimp.

Metamorphosis is simply a term to describe the transformations which take place under our own eyes, but the pre-natal development is equally metamorphic. All livingcreatures pass through all the stages common to the race below them, finally branching off to their own special class. 'This is the most mysterious and deeply-seated principle of life-growth. The stepping-stones of upward life are the vanishing forms of all the past. Each new stage is a birth from the preceding. All is metamorphosis from first to last. What can all this mean? In vain we ask the advocates of the Creation theory to explain. Like Sir John Falstaff, they will give no reasous on compulsion. We find in Metamorphosis the strongest support to the great law of Evolution, modification and adaptation operating every where on the children of life.

\section{PROOFS FROM RUDIMENTARY ORGANS.}

The proofs of the Evolution theory from the existence of Rudimentary Organs are as interesting as convincing. Nature has strewn the life-path with dwarfed and dying. forms, which testify to her marvelous work in moulding mind and matter. She never quite hides her tracks, but leaves in bone and tissue, in rock and flower, memorials of her brooding care. Her earliest children were lowly born, and over their natal-bed arose the rythmic murmur of the 
sea. Rocked on its billowed breast, these children grew and filled the early waters with their kind, from which developed all divergent forms. Throughout this upward struggle of elemental life, Heredity, like a miser hoarding his bags of gold, has kept brief remnants of family traits for ages, letting them go only as compelled by the iron grip of that "fierce Spirit of the glass and scythe, Remorseless Time."

We will note a few of the Rudiments which inheritance has still preserved, and let them serve as examples of the multitudinous whole. It is well known that the baleen whale has no teeth, and no use for any; yet its embryo has a full set, which disappear before birth by absorption. The plain inference is that the whale has not always been a water-animal; that his ancestors had teeth and legs, and roamed through forest, swamp and marsh. In some whales, also, pelvic bones are found, and yet they have no hind legs. Such bones are mere rudiments of the former attachment of legs. Again, rudimentary hairs are found in the skin, being but fragments of the hairy coat their ancestors once wore, before they paddled their own canoes on the briny deep. The breathing organs of the whale are modeled for air-breathing, not for water-breathing. It would thus appear that our great oil-producer came first from the water, then acquired the structure of a quadruped, and finally went back again to his native deep. Why did he go back? Will our theological friends say, "It was to swallow Jomah"?

The Python, also, has rudiments of legs; and the embryo of the calf has teeth which are absorbed before birth. The splint-bones of a hor'se's foot, the turtle's flipper, the dewclaw of dogs, the tails of birds, and the gill-arches of reptiles, are all useless rucliments. The crabs and fish in the Mammoth Cave have lost their eyes by disuse, but the sockets remain as rudimentary remmants. But more significant than all these, are the proofs furnished by the highest animal - Man. In all parts of his bodily structure are found the strongest evidences of his animal origin. $\mathrm{He}$ has dormant scalp and skin muscles, which were of great service to his ancestors, but of no use to him. Many persons are found who still possess the faculty of moving the scalp and ears in a remarkable degree, owing, no doubt, to the fact that their ancestors have continued the habit. 
Man has a remnant of a third eye-lid, now possessed only by some birds and beasts, in the crescent-shaped fold next to the nose. The nipples and mammary glands of males are wholly useless and suggest the differentiation of the two sexes from a common parent form. The sparse covering of hair on the human body is a lingering reminder of a time when clothes were at a discount. Even now we see some. hairy specimens of humanity exhibited as curiosities, which doubtless represent a reversion to ancestral conditions. The thyroid gland in man is a rudimentary and wholly useless organ, which sometimes becomes the seat of certain forms of disease. In man as in some of the lower animals, a sort of pouch about two inches long, which is not only useless, but is a constant source of danger, is attached to. the cæcum of the large intestine.

Another proof of man's descent from an ape-like ancestor, is the fact that the human embryo, in common with such animals, has at one period of its growth, a free projecting tail, which shortens up before birth, leaving, however, several well-defined vertebre at the end of the spine. These are wholly useless and are, moreover, subject to. injury.

The vascular system in man is also far from perfect, as we still retain, in part, such valvular arrangements as are best suited to the quadruped; and for want of a better. arrangement many of life's ills are due. Many of the visceral attachments in men, and especially in women, are also adapted to a creature which walks on "all fours," but are very imperfect in their adaption to an upright posture of the body. If man was created out and out, such workmanship implies a woeful want of wisdom or constructive skill on the part of his maker. 'These facts, however, are readily explained on the theory of Evolution.

\section{PROOFS FROM GEOGRAPHICAL DISTRIBUTION.}

The doctrine of Derivation is much strengthened by the study of the distribution of animals over the globe. We find the dispersion just such as we should expect to see if the theory of evolution were true. If created suddenly, we ought to find them after their kind, indiscriminately inhabiting islands and continents. But, instead, we find that the greater the isolation of the island, the fewer. animals; and those found are more specialized in type. 
On the other hand, where opportunities for migration have been favorable, we observe the greatest variety of life.

Again, if specific centers of creation were the method, each species would be best fitted for its own environment, and could not exist in any other. But the facts show that both animals and plants will flourish far away from their native homes, under totally different physical conditions; in many cases with decided advantage from the change.

There are many factors which give rise to diversity of organism as influenced by geographical location, such as temperature, the effect of mountain barriers, and glacial action which induced migration. 'This subject is so broad and deep that we have only time to mention the remarkable facts concerning the fauna and flora of Australia. Its entire range of animal and plant-life, with trifling exceptions, is found nowhere else on the globe. Among the great land-areas of the earth, it presents a striking case of retarded evolution, shown alike in species, genera, families and orders. It is a comntry of synthetic types. We still have there the egg-laying mammals, and the pouched marsupials, of which there are many species; but of true mammals, there are none. Australia and a few other oceanic islands - notably the Galapagos and Madagascar seem to be but rudimentary parts of the great body of the globe. Here the tide of Evolution has been checked. Even the natives are among the lowest in the scale of human beings.

What is the significance of all these facts? Why should Australia be some ages behind its rivals of like climate and soil? It is still in the Mesozoic age. The answer is inevitable. This great island, though doubtless once joined to Asia, lies in complete isolation, thus shutting out the migration of fierce animals; and those now there have changed but little from earlier types. The reason for this lagging development is the comparative absence of that fierce struggle for existence, which elsewhere prevails. No lion is there to frighten and destroy the kangaroo; no howling wolres to chase the monotrema. Australia is monkey.less and ape-less, although these animals abound elsewhere in like climates. Wherever the battle for life has been strongest, there we find the greatest jrogress and variety of development. The dwellers of mid-ocean islands have had an easy, lazy time of it. "Far from the madding" 
crowd's ignoble strife, they kept the noiseless tenor of their way."

As Mr. Wallace remarks: "TVe find the continental islands inhabited by animal life more or less similar to that of the mainland, according to the time and clistance of the separation." All these facts are in perfect harmony with the theory of Evolution, and utterly at variance with any other hypothesis whatsoever. From the first dawning of life to the present moment, varieties of animal-forms and organs have developed most rapidly under the spurring whip of the fiercest warfare - a warfare not only of life against life, but of Nature against all. Heat and cold, dryness and moisture, wind and ticle, lightning and storm, flood and fire, mountain and chasm, pestilence and famine, mist and darkness, one and all have stood like frowning giants in the path of living forms. But in spite of all these barriers, in spite of inter-racial strife of beak and claw, of tooth and venom, the residuary column has pushed onward and upward, readjusting itself to ever changing conditions. Indeed, this very opposition and antagonism have been the potent factors in the ascent of animal life. Australia has not kept pace with the continents because the warfare there has been little more than a skirmish. The continents have advanced under the great law of might. The weak, the indolent, and the stupid, were swept from among the living; the strong, the resolute, and cumning, remained victors. Evolution, and Evolution only, explains the facts of Geographical Distribution.

\section{PROOFS FROM DISCOVERED LINKS.}

Where are your "Missing Links"? cried the critics of Evolution after their recovery from the first shock of Mr. Darwin's "Origin of Species" in 1859, and again after the publication of his later work "The Descent of Man." From theological quarters, after the laugh had subsided, came severe denunciation of the doctrine. It was said that the Evolution hypothesis was both childish and dangerous, and that Darwin himself was the Munchausen of his time. Even to-day, thirty year's from the time of that remarkable publication, the masses - those inmocent of any learning on the subject, and those who study fortified to disbelievealike cry out in chorus, "Show us the "Missing links." This outcry has narrowed itself down to the demand for 
man's immediate ancestor. They want an ape who can build a fire, whistle, and sing the Doxology; though they might possibly throw off the fire and the whistle.

Before opening the cabinet of "Discovered links," it may be well clearly to understand just what we should, and just what we should not, expect to find. First, as to those living links which we do not find, it may be affirmed that their very absence is proof of Evolution. Its vital principle forbids their presence. Natural Selection sends the weakest to the wall, and so the transitional forms do not live to be looked at. No one life, nor a thousand, is long enough to observe the changing forms. As Mr. Darwin remarks: "They perish by the very process of the formation of the new species." A hundred thousand years or more have doubtless passed since man was first a man. His ancestral link was prior to himself, and could not have survived after man was fully evolved. It could not remain a link, but must push on to a fully developed man. If it were not so, Evolution would be but a childish dream.

But the graded forms from brute to man, have all been on the earth. "Why," you ask, "do we not find their remains now?" For this reason: Only now and then one was drowned; for it must be remembered that ocean travel was limited in those days, and yachting parties were somewhat exceptional. It is doubtful whether the "Missing Link" was either a sailor or a swimmer. Now, it is obvious that only those links meeting a watery fate would stand any chance of being preserved in the stratified rocks for subsequent discovery. Besides, a link before becoming immersed in hardening mud and sand, would do well if he escaped being eaten by link-eating monsters of the deep. And as for being preserved on land, what could one poor little heap of bones do as against the mutation of half a million years? Therefore, in the very nature of time and things, we could not certainly expect to tind a man-like link, living or dead. The soft parts of animals and plants, from their very nature, must disappear. The rocks themselves crumble and waste away, to be borne to the sea again with all their wealth of fossil forms. The earth is broad and deep, the stones hard, and the searchers are few ; and moreover, the work is hardly yet begun. A museum of "Missing Links" will be the attraction of the future. Nevertheless, with the door of Nature doubly barred, our sturdy scientists 
have broken through and disclosed some of the rich treasures beyond.

First, we will notice some of the living links to be found, not on account of Evolution, but in spite of it. These are cases mainly of retarded or arrested development, which will doubtless culminate at last in true types, the links finally disappearing. The most interesting group of synthetic types are the Amphibians - interesting because it explains how we got out of the water, and into the woods. The frog, whose transformations have already been referred to, is the most familiar example of this group. 'The shores of the early seas were doubtless the scenes of many equally remarkable transformations. The creatures, ocean born, were brave and hardy fellows, and bent on becoming landlubbers at any cost. All the Amphibians must be regarded as links between the true water animals and land animals. Their swim-bladders were made into lungs, their fins into legs, their scales into hair and feathers.

The living link between the egg-layers and the milkgivers is the class of Marsupials, of which the Kangaroo is a familiar example, which bring forth their young in an imperfect state, the development being completed in a pouch in front. In fact, the entire fauna of Australia may be regarded as generalized types. Prof. Owen has described two curious creatures discovered there, - the echidna and ornithorhyncus, - still more primitive than the kangaroo. 'They are pre-marsupials. 'They are both egg-layers, as no' other hairy quadruped is. Their eggs are placed, that of the echidna in a pouch, as the marsupials carry their immature young, and that of the ornithorhyncus in a nest, and there hatched. Like no typical egg-layer, they suckle their young. The ornithorhyncus, which has a bill like a duck, has bones resembling those of bircls, reptiles, and seals. What can all this mean if not descent with modification? Professor Huxley declares: "On the evidence of Palæontology, the evolution of many existing forms of animal life from their predecessors is no longer an hypothesis but an historical fact."

'The links between the animal and vegetable kingdoms are abundant. The Rhizopod is a fine example. It has sensation, and seemingly purpose, though non-cellular and inorganic. The polyp has no arterial or circulatory system. It consists of simple layers of cells, and is propagated by . 
buds. Here is a being which eats and grows like an animal and yet is propagated like a vegetable. The sponge is an egg-layer. Its eggs bud or hatch and grow to adult life. These cases among the Protista, which are neither strictly animal or vegetable, suggest the beginning of differentiation from a common protoplasinic cell.

Turning to the fossil world, we find, as we should expect, innumerable examples of connecting forms. In the later deposits, we find remains of toothed birds, having many reptilian characteristics. Reptiles were then not a fixed type, but shaded gradually from fish to bird. The Archæopteryx, a fossil rarely found, was a true link between the birds and reptiles.

Certainly, no two kinds of living things are more unlike than birds and reptiles, or more antagonistic in their natures, mutually preying on each other; and yet their relationship is clearly established. Psychologically, they have nothing in common but hate; and yet the bird is only a feathered reptile. Within three years, there was found, in the slate deposits of Bavaria, a specimen of a reptilianbird - now preserved in the British Museum - which has a long, lizard-like tail of twenty joints. Says Professor Vogt, "This is neither bird nor reptile, but a decided link between the two." In the later chalk formations many fossils have been found by Prof. Marsh, more bird-like in character, but still possessing teeth. The flying dragons afford another link between birds and reptiles. The front half was decidedly bird-like, but the hind legs and pelvis were strongly reptilian.

The anaplotherium connects the swine with the cudchewers; the zeuglodon connects whales with seals; and the palæotherium connects hogs with the rhinoceros. These are all true links.

A remarkable example of a perfect succession of links is found in the fossil shells of the Tertiary rocks of Wurtemberg, which are literally packed with fossil forms. These shells show a complete grading to correspond with the order of the rock-deposits. Here is evolutionary perfection without a break. The life once within these shells, in its tribal history presents no "missing links."

To sum up, we find the sponge family - the animal-vegetable - near the original protoplasm. The lancelet - the first of the back-bone tribe, with only a line of cartilage in 
place of spinal vertebrae - connects fishes and mollusks; the amphibians connect fishes and mammals ; the Archæopteryx comnects birds and reptiles; the kangaroo comnects egg-layers and milk-givers; but between man and the ape there is no living link. Nor can there be if Evolution is true; yet it is not less certain that he has been evolved from a lower animal form than that these other steps in biological development have taken place.

Professor Wilson, of Elinburgh, says: "There can be no Evolution for one group, and special creation for another. There can be no Evolution for the lower races, and creation for the higher forms of animal life, or for man himself. Uniformity and sequence exist wholly, or not at all." Prof. Huxley also declares, "If one series of species has come into existence by the operation of natural causes, it seems folly to deny that all may have arisen in the same way."

It has been truly said, "Of special creation the rocks tell no tale." Nor do the present living forms which roam beneath "this brave o'erhanging firmament," while all the fossil dead, and all living creatures, give out some hint or indication of the things they were, and of the evolutionary process through which they have reached their present estate.

PROOFS FROM ARTIFICIAL BREEDING.

It is well known that nearly all domestic animals, foodplants, fruits, and flowers have been greatly improved by man's endeavor to produce higher and better forms. His success has been phenomenal in modifying size, form, color, speed, strength, and beauty. If such marvelous results may be achieved in one individual's lifetime by accelerating the Law of Selection, what wonders might we not expect Nature to perform in the ages gone by?

The wild species have been modified by Natural Selection during countless ages. In a degree man can repeat and augment this developmental process in his own brief life; nay, he can almost witness an entire change of species. Individual inheritance is from all the preceding race, but strongest from the immediate parent. Heredity is cumulative, and tends toward fixity and stability, until finally the opposite tendency to reversion is overcome. Professor LeConte says: "During the brief history of man, races of the different domestic animals and plants have been found, differing so greatly from each other that if discovered in a 
wild state they would certainly be called different species, and in some cases genera. If art accomplishes this result by Artificial Selection, why not Nature by Natural Selection?"

The objectors say, "We cannot admit this evidence, for, if your improved breeds are turned out again, they would revert to original types." The Evolutionist replies: Heredity is a plant of slow growth. It increases slowly and holds firmly; time is the measure of its strength. If pushed rapidly, it will hold lightly. This is a universal principle; what is longest in coming to maturity is strongest. He answers likewise: Domestic animals, if sent back to the wild state, enter a new environment and must begin anew a struggle for existence in competition with their fellows of the woods. They are out of harmony with their former artificial conditions, and a readjustment must take place. Tame and wild animals are put on common ground. They are forced into competition, and must needs fight or die. The very principle of Evolution demands reversion in such cases.

There are, however, two interesting questions, not yet fully answered; although they do not affect at all the truth or probability of the theory of Descent. First, what is the cause of variation? And, secondly, What is the cause of the first step in usefulness? Why should there be a tendency to vary?* Use can improve an organ, but how can it start one? And how does it start itself? The answer to these questions may perhaps be found in subsequent investigations of the psychological phases of the life-problem.

\section{PROOFS FROM REVERSION.}

One of the most curious facts of Evolution is the tendency to revert to ancestral forms. This at first seems to weaken the theory of Descent, but in reality it gives it great support. It is all a question of environment. If that remains the same, there will be little change in life-forms; for this reason the King-Crab and the Nautilus of to-day are quite similar to their fossil parents. If former life-conditions are restored, what is more natural than retrogression? But even here, paradoxical as it may seem, there is really

* Since the delivery of this Essay, a writer in the "Popular Science Monthly" for April, 1889, maintains with much force that the Tendency to Vary is due largely to Psycho-Physiological influences. 
progress, for Evolution always insists on the readjustment of organs to environment. The changes are best for the animal under the circumstances, and therefore truly an advance for him. This tendency to reversion is shown by the stripes on some horses and mules - a survival of the stripes on the wild horse, such as we see on the zebra; also, by the animal teeth, peculiar muscles and hairy covering possessed by some men and women. The barnacle, once a free-swimmer, is now a lazy ride-stealer, a freebooter and pirate of the sea, threatening to scuttle the ship. Some island insects and many varieties of birds have lost the power to fly by long disuse of their wings, safety and food not requiring flight. The whale has lost his ability to walk on dry land. In general, when any organ has become useless, it tends to retrogression, and finally becomes rudimentary. Nature abhors the useless. But this reversion is always slow, as Heredity is ever jealous of her store.

Reversions are but eddies in the great stream of Evolution, and like eddies show the direction of the current. It is as though Nature had sent a courier back a little way to guicle us more clearly on in our investigations. This feature of Evolution, theology should accept since it recognizes the principle of "back sliding." The mites and ticks have doubtlessly fallen from spiders and scorpions. The insect, Stylops, with aborted wings, has sunk back from a free-flyer to the ignoble life of a parasite.

In closing this branch of the subject I will quote Prof. Wilson: "While progressive Evolution develops the great tree of life, extends each branch, clothes it with verdure, and expands each blossom, it is degeneration which lops off the worn and aged stems, prunes the weakly foliage, trims the budding growths, and so directs and moulds the outlines of the organic whole."

\section{PROOFS FROM MIMICRY.}

Mimicry, or the imitative faculty of some plants and animals, gives us most interesting testimony for Evolution. Some insects and birds, through the law of Natural Selection, in configuration and color are like the natural objects over which they roam, thus securing a degree of protection from their natural enemies. The brooding bobolink harmo- 
nizes with its nest, while its unfettered mate in gay attire soars happily around. But the valiant crow needs no protection, and so is "black as crows can be." Those female birds and insects which serve as prey for their enemies are inconspicuous in color, while their mates are dressed in fine raiment. That curious little insect, the walking-stick, looks precisely like a brown twig broken from a tree; other's resemble the leaves of plants which grow in their neighborhood. Some animals feign or mimic death to escape such foes as devour only what they kill. Others, again, resemble a more ferocious animal, and thus secure immunity from attack.

Not all creatures, however, are thus protected, especially of the domestic class. But why should safety by imitation be accorded to some and not to all animals, if all things were created out of hand? Some are left defenceless; others are aided in concealment. Every animal has his foe, and must battle for his life. This, from the point of view of special creation, does not look like eternal and evenhanded justice. It looks, rather, like a logical result of the operation of Mr. Darwin's great principles of Natural and Sexual Selection.

\section{SPONTANEOUS GENERATION.}

There are two classes of scientific travelers, who go back on the Evolution road happily together, until they reach the point of Spontaneous Generation, and there they part company with none too friendly voice. The one with theological views insists that the germ-cells were created, just as he once used to think Adam was created. The other maintains that this speck of protoplasm was formed by cheniical and electrical action, and other natural means, operating under once favorable conditions on the primitive slime; and that from these primordial cells all succeeding life has sprung. In other words, he believes that the lifeprinciple is resident in matter itself, needing only vivifying conditions to make it active. Why our theological friend need diverge at all is not clear. If simply the power and wisdom of a Creator are in question, there should be no disagreement; for it is certainly a greater display of Creative skill to make an all-pervading law than to make out of hand a few germ-cells. It is greater to evolve a principle 
than make a simple thing. A thing wears out; a principle is eternal.

It would seem that Evolution camnot fairly stop at this little atom of carbon compound. Is it afraid or powerless to take the mystic step between the living and the nonliving? Did Evolution operate all the way from "stardust" down to this little speck and then cease to operate? Could it make worlds, suns, and systems, and yet prove inefficient at this vital point? Is it not grander to think we were made out of something than out of nothing? If creation really was the method, why give us the Garden of Eden, with the Fall of Man thrown in, rather than the millions of years of struggling, warring life, in order to reach our manhood. If we were created then, why was it necessary to start us so low?

But, say the critics, "If life was evolved once out of inorganic conditions, why not again?" Why not, indeed? Who knows what life is evolving in torrid climes under the deep-sea ooze? But it may be that the conditions of lifebirth have forever passed. No one has yet proved or disproved beyond the shadow of a doubt the method of the genesis of life on our globe. But there is no reason to suppose there has been a break in Evolution, and every reason for believing that it has formed one continuous line of succession from Nebula to Man. There is no element in plant or animal not found also outside of them. It is mimicry or imitation on a grand scale from first to last. The Moneron has bequeathed its albuminous carbon compound to all subsequent life; and we are what we eat and walk on. The formation of the erystal corresponds to inheritance and adaptation in organic evolution. It is all a question of degree. Professor Haeckel and many other eminent scientists hold this view. Professor Tyndall says, "Matter has in it the promise and potency of all forms of life."

In closing we will briefly present

\section{A SUMMARY OF EVIDENCE.}

Astronomy declares the unity and universality of the laws of gravitation and evolution. The Nebular Hypothesis explains how by the operation of these laws "the infinite meadows of heaven" are filled with orbs "unutterably bright." 
Geology describes the Evolution of the Earth from a formless void to wrinkled age. Entombed within the leaves of rock are found in nice gradation all forms of upwardtending life, no sharp lines between the types, but insensible shading from first to last. As a writer happily puts it: "It is as if Nature wrote her own autobiography, using for an alphabet the hieroglyphics of life."

Embryology testifies as to the method of animal evolution. It is a brief summary of the story of the race in the life of the individual, a rehearsing of the sublime drama of all time. Is this all a meaningless phenomenon, a senseless panorama? Is this "epitome and brief chronicle" of the ages only a whimsical incantation of some occult power? Is it not rather, on the contrary, a demonstration of Nature's method of Evolution?

Metamorphosis makes this assurance doubly sure; for we can see the evolving forms before our very eyes. Nature is an unsolvable riddle only to the sightless and thoughtless.

Rudimentary organs are amorig the strongest proofs of descent, and are present throughout the animal and vegetable kingdoms. To the biologist, man is a curiosity shop, the whale a traveling museum. Was Man created in the image of his Maker? Why, he isn't half made yet. The chips of the shop are still on him. He needs yet the emerystone of time. But he is in the hands of a tireless Master, deft fashioner of form and function-Evolution.

Artificial Breeding is proof of the method of Nature's workings. Man can accelerate the process of Nature. $\mathrm{He}$ has given us better stock and better food-stuffs. Darwin in twenty years accomplished what it would have taken Natural Selection thousands of years to do. By following the method of Nature man has become the originator of higher forms - a conscious factor of Evolution.

Reversion says that the two kingdoms of life are full of antagonisms - that ebb and flow are in the heart of all things - that strong and stubborn Heredity has a master environment. Heredity never originates. It merely holds and perpetuates. If the surroundings are more favorable for return to the parent form than to the maintenance of the derived form, the organism will go back to the former. Life-forms may go onward or backward according to the demands of adaptation. But the final result is progress it is Evolution. 
Geographical Distribution furnishes evidence of the strongest kind for the case of Evolution. It explains the wide diversity of animals and plants on the earth, that they have sprung from common sources, and have become scattered by migration and other causes. The wider the separation of islands the greater the variation of organic types from their kindred on the mainland. These facts point away from the creation theory, and directly to Evolution.

Homology, or the Science of Likenesses, throws a flood of light on the question of development. It proves, by the exhibition of the successive steps, how the whole was accomplished. Mr. Spencer says: "What now can be the meaning of this cornmunity of structure among these thousands of species? To say it is the work of design, to say that the Creator followed the pattern throughout, merely for the purpose of maintaining it, is to assign a motive which if avowed by a human being we would call whimsical." The only rational explanation of natural homologies is Evolution.

Mimicry, or Imitation, adds a strong link to the chain of evidence in support of evolution. When strength or courage is wanting, cunning supplies its place. This imitative tendency extends over a wide range of life-forms, and even enters the circle of human society. Few men or women dare be original and independent, fearing to meet the shafts of malice and detraction. To imitate others is the safest way. Therefore all reforms, high thoughts, and new ideas, find slow acceptance; but to these alone we look for progress.

The new theology, based upon Evolution, has to combat the selfish propensity of man to seek for his own ease and and resist progress and change. It is easier to dream and be common than to think and be exceptional. It is all a question of the gray matter of the brain,- of Evolution.

\section{LANGUAGE AND THE MORAL SENSE.}

The great difference between man and the lower animal is the possession by the former of Language and the Moral Sense. This difference as at present manifested is indeed almost infinite. But let us go back on the tide of timeback even thousands of years before the cave-men, when speech was but a chatter and conscience was as yet un- 
developed; then the difference would be a vanishing quantity.

The higher animals, in common with man, manifest joy, sorrow, love, hate, fear, courage, fidelity, gratitude, jealousy, memory and reason, and these qualities are clearly shown in their actions. One dog will watch another at his bone without interfering with the right of prior possession; but once let it be abandoned, and the watcher's paw upon it, let him take it who dares! 'This is a recognition of the principle of ownership and property-right, and therefore contains a glimmer of conscience. With the development of the larynx and the brain in man came speech and conscience, and all the heights of mind.

\section{CONCLUSION.}

The final question which demands our attention is, How does man stand to-day, affected by Evolution? By it we are chained to all the past; we are pledged to all the future. We are a part of Universal Life, of life supreme, of life eternal. We have always been coming; we will always be going. Our influence for good or ill will be everlasting. The difference between the atom and the All is one of degree, not of kind. TVe are kindred at once to the highest and to the lowest.

The crown and jewel, the bloom and fruit of Evolution is moral grandeur-is conscience. Like mind, motive, reason, will and language, it was lowly born, and has risen from the manger of consciousness. It is the collected inheritance of the best tendencies of life.

Evolution insists on the importance of this world, and yet from Love that stands waiting to clasp its idols in a future life, it takes no hope.

Evolution is sweeping from the world a crude and cruel theology, giving forth a promise of "sweetness and light," - of better social conditions and individual progress. The old theology worships the Unknown, and prays to change the changeless. It believes at least in "Theological selection," insuring the survival of the "elect," while the tropic storm of pain sweeps over all the rest. Erolution has entered every pulpit, and softened every harsh roice, and is hopeful of the time when to creedless moral beauty, man will concede a crown. 
Man entered the world, as Evolution assures us, not in disobedience, but in mison with the two grandest forces in breathing Nature. He began life with innocence, and under the inspiration of Hunger and Love. The one led to the divinity of Labor; the other to the heights of Happiness. Theology declares that he began the world turned out from Paradise; Hunger without a crust and Love without a home. The one idea was upward; the other downward. Which is better?

In this presentation of the case of Evolution, I am aware that only the borders of the broad field have been touched. The fulness of ripe-eared Truth lies yet in store. If I have made you hungry, it is well. 


\section{ABSTRACT OF THE DISCUSSION.}

\section{Mr. Nelson J. Gates:-}

In discussing this subject, I labor under the disadvantage of almost entire agreement with the lecturer. The proofs of Evolulution are of the nature of mathematical demonstrations. As in geometry the statements as to the relations of lines and figures are a reflection of the nature of things, - of that which cannot be otherwise,- - so in evolution the history of the development of a single cell is of the nature of a statement of axiomatic law. The law of development is within, not without, and we need only apprehend it to see its truth. Simple laws are readily seen to be thus axiomatic, but in a complex problem we cannot so readily educe the law; but it is there nevertheless. The debatable ground at present in Evolution is the question of the origin of life. Evolution has not yet proved that spontaneous generation has occurred, but its assumption that the forces of Nature were sufficient to cause the appearance of life is justified by the known facts of biological development. The other alternative, that of special supernatural creation, has nothing but ignorant tradition to support it. Spontaneous generation is shadowed forth by the strange phenomena of frost-work, in which we often see the forms of ferns and flowers imitated perfectly. The process of crystallization is akin to the process of growth in organic forms.

\section{Dr. Robert G. EcCles:-}

While the popular mind is somewhat slow in grasping the truth of Evolution in its comprehensiveness, yet it is a fact that all men are evolutionists, whether consciously or not, in the things that they know - so far as their actual knowledge goes. In our own minds the thoughts that are most fitted to the environing personality are those that survive. Even in theology, the influence of Evolution is evident. Indeed, the founder of Christianity himself accepted the principle of Evolution: "First the blade, then the ear, then the full com in the ear." The principle of continuity is one that is often overlooked by evolutionists. The illustration used by the lecturer, of the fish using fins for land locomotion until they developed into legs, is one that enforces this point. There is nothing new in itself; but there is continually new synthesis. In the past is the foundation of all that shall appear in the future. You and I differ on some subject; we are neither wholly right; we each have a part of the truth; we compare experiences and thoughts, and synthesize them into a new truth that is complete for both of us. Wrong synthesis is the trouble with the theologians. In the 
most perfect man there is simply a development of the functions and attributes of the lowest organism, the amoba. The observation of this universal fact of continuity - that nothing anywhere comes from nothing-constitutes the strongest philosophical proof of Evolution.

\section{Mr. BenJamin ReECE:-}

Let us note some of the convincing proofs of Evolution in the field of Sociology. Professor Clifford says, the selfhood of the tribe is of more importance than that of the individual. In animals that were gregarious the chances of survival were greater than in those which were not. Slavery, in the evolution of morals, was an advance upon cannibalism; it at first was prudential, then it became immoral to kill in cold blood. The influence of environment upon morals is seen in negro slavery in our own country. In the North, where slavery was unprofitable, its ethical wrong was earlier seen than in the South, where the institution was of advantage to the slave-owners. Again, in the North the moral perception was manifested in denunciations of the inhumanity of the practice of slave-holding; in the South, in the kind treatment of the slave. Now even the slave-holder has discovered that slavery was both economically unprofitable and morally wrong; and slavery is universally condemned, because it has been proved to be unsuited to its environment. With the decline of the ancient tribal fealty, and the sense of personal comradeship, connes in the feeling of a wider relationship, of a universal brotherhood. In some communities, however, the fact of brotherhood and equality of rights is perceived subjectively before the functional development of the masses renders its legal establishment practicable or possible. Hence arise conflicts and political dissensions. A sudden change in environment, for which the subject is not prepared, results disastrously. Thus the North American Indian, in common with other savage races, was not prepared for the additional leisure which the improved implements of warfare furnished by the whites gave him, which enabled him to procure subsistence in lialf the time which had formerly been required, and left him without sufficient occupation, while, to make a bad matter worse, the white man's stimulants came in to fill the gap. He was not prepared to use the advantages of civilization, which were suited to the condition of the white man because he had evolved them. There was a break in the continuity. Without occupation, man reverts to his original barbarous condition, as seen in the sports which engage the attention of the wealtlyy idlers among us, of which horse-racing and fox-hunting are illustrations. 


\section{EVOLUTION AS RELATED TO RELIGIOUS THOUGHT}

BY

JOHN W. CHADWICK

AUthor of "The Bible of To-DaY," "The Faith of Reasoy," "Charles Rober't DARWIX," etC., ETC. 


\section{COLLATERAL READINGS SUGGESTED}

IN CONNECTION WITH ESSAY XIII.

Spencer's Sociology and Discussion with Frederic Harrison; Max Muller's Science of Religion; Powell's Our IIeredity from God; Fiske's Cosmic Philosophy, Unseen World, Destiny of Man, and Idea of God; Abbot's Screntific Theism; Le Conte's Evolution and its Relation to Relignous Thought; Dr. McCosh's The Religious Aspects of Evolution; Mivart's Lessons from Nature as Manifested in Mind and Matter; Martineau's A Study of Relizion; Stewart and Tait's Unseen Universe; Clifford's Unseen Universe (in Lectures and Essays) ; M. F. Force's Darwinism and Deity ; W. Stanley Jevons' Evolution and the Doctrine of Design (in Popular Science Monthly, May, 1874); Professor Youman's Spencer's Reconciliation of Science and Revigion (in Christian Examiner, May, 1862); Conder's Natural Selection and Natural Theology; Strauss's Old Faith and the New; Darvinism and the Christian Faith (in Popular Science Monthly, May and June, 18s8). 


\section{EVOLUTION AS RELATED TO RELIGIOUS THOUGHT.*}

I APPRECIATE the kindness of the Ethical Association in allowing we the first word and the last on the most seriously interesting topic of the present course of lectures and discussions. The embarrassment of riches it entails has been considerably lessened by two preceding lectures Mr. Sampson's on the Evolution of Theology and Dr. Janes's on the Evolution of Ethics. From this precedence it will appear that I am not expected to treat of the Evolution of Religion but of Evolution and Religion, i. e., of Religion as affected by the doctrine of Evolution. My talk would be still further circumscribed, in fact my occupation would be entirely gone, if Ethics were, as some insist, all there is of Religion; for Dr. Janes added to his treatment of the Evolution of Ethics some treatment of the standing of Religion ethically considered in the light of Evolution. But the ethical exhaustion of religion I cannot by any means allow. I believe that "Ethics thought out is religious thought; Ethics felt out is religious feeling; Ethics lived out is religious life"; but so thought out, felt out, lived out, it is not the only religious thought, feeling and life that are possible for us. Ethics is part and parcel of Religion only by historical adoption, and the tendency of "all thoughts, all passions, all delights" in the last analysis to lose themselves in God. If we were of those who insist upon the limitation of terms to their original significance, we should insist upon the absolute difference and separateness of Ethics and Religion, for the reason that in their original characters they were different and separate. 'The first Religion was not ethical; the first Ethics was not religious. These streams of thought and feeling were like two rivers, say the Mississippi and Missouri, rising in different upland tracts, but at last uniting into one rejoicing flood. It is oftentimes about as difficult to distinguish Ethics and Religion in the blended flood with which we

* Copyright, 1889, by The New Ideal Publishing Co. 
sweep along, as it is to distinguish the waters of the Mississippi and Missouri below their uniting place. It has often been insisted that the Missouri is the continuous river, the Mississippi the tributary; that the present naming has no justification in physical geography. If one should contend that Ethics is the main, Religion the tributary stream, I think it would not be very difficult to make this contention good. But those who insist that Ethics is exhaustive of Religion and is entitled to the name are precisely in the fix of an imaginary person who should declare that so much of the united flood of the Mississippi and Missouri as the Missouri furnishes should be called the Mississippi and the rest should be ignored.

You will agree with me that these are vain and fruitless speculations. The positive method is the best. Religion, as it now is in the world, is a flood of many waters. Into it Ethics has poured its vast Missouri, man's sense of his relation to the universe and its controlling powers its Mississippi (perhaps this as the more stained and turbulent had better have the other name), and man's engagement with the idea of a future life its immense Ohio. Religion as it is at present constituted in the world is composed, with emphases that vary with its different sects and schisms, of these three elements: Men's thought and feeling about God, about Immortality, and about the Moral Law, and of their action determined by such thought and feeling. If as I go on I treat almost exclusively of the relations of doctrinal evolution to the ideas of God and Immortality, it will be from no comparative disrespect for Ethics, but because where Dr. Janes has reaped I do not care to glean.

The evolutionist need never have had any fear that if he could establish his doctrine, if he could win for it the consensus of the competent among scientists, the organized religion, even the orthodoxy of the time, would find it perfectly harmless, would indeed insist that the Bible taught it. How like to Emerson's

"And, striving to be man, the worm Mounts through all the spires of form,"

is the New Testament verse, "The earnest expectation of the creation longeth for the manifestation of the soms of God." Only it must be confessed that nobody ever suspected any Evolutionism in this till Evolutionism had been 
painfully wrought out by Darwin and Spencer. The church in every period of its domination has held a mirror up to the triumphant systems of philosophy and science. It has reflected these. It has opposed each new departure; it has applauded each accomplished victory. It has been compared to the prince who summoned his courtiers about him to see the sun rise at his bidding. The moment it began to peep above the horizon he said very solemnly, "Now rise!" and sure enough, it rose. But this comparison is too flattering to the church. Its average disposition has been much tardier than the prince's in the story. The sun of each new day of science has had to climb all the way up to the meridian before the Orthodoxy of the time has given in and said, "I told you so!" and proceeded to give chapter and verse. The doctrine of Evolution is the last of five great scientific dawnings since the mind of Christian Europe returned upon the scientific mind of Greece in the 14th and 15th Centuries. The first was the Copernican astronomy. Long and hard the church insisted that if the earth was not central to the solar system and the sidereal universe, there was no God, no Christ, no revelation, no any thing that religion had held dear. When it had to accept it, then it concluded that it could, without detriment to any precious thing. That the Copernican astronomy was absolutely fatal to a theological scheme which held the earth to be the moral centre of the universe there cannot, I think, be any doubt. The moral centrality goes with the sidereal. However this may be, Orthodoxy soon settled back into her old complacency. Then Newton came announcing the law of gravitation. This seemed to say the universe could go alone. The theological dovecotes were again badly fluttered, but it was not long before every dove in them was cooing Newton's praise. The next great scientific discovery was geological - the antiquity of the earth. B. C. 4004 was the accepted reckoning, and the day was October 18th, if I remember rightly. As many millions would not now be thought too much. But at first the geologists themselves were driven back very slowly by the array of facts. Some of you can remember the whole process of the church's caving in. At first the new geology was denounced as sheer atheism. The Bible said that the whole world was made in six days; the new geology that it has been making many millions of years and was not finished yet. Then came the fine discovery 
that the days of Genesis were geologic periods of indefinite length. Why, yes, of course! Why hadn't anybody thought of it before? But while this discovery did much to soften the fall of Orthodoxy, it was soon perceived to be invalid by the more intelligent and sincere. Thus was accomplished the first serious abridgment of the claim of Biblical infallibility. It is not too much to say that the intelligence of the church is at the present time wholly committed to the immeasurable antiquity of the earth and of the cosmos, and hardly less so to the conclusion that a literal rendering of the six days of Genesis is the only rendering of which the document admits. Following quickly on the discovery of the earth's antiquity was the discovery of the antiquity of man. 'This is now reckoned from five hundred thousand to a million years. There is more danger of reckoning too short a time than one too long. For the theological fall of man this substituted a rise through many stages of progression. It was bitterly opposed, but the indefinite antiquity of man is now a doctrine co-extensive with the general intelligence and culture of the Christian world.

With such a history at his command, the evolutionist of thirty years ago need not have feared but that Orthodoxy would eventually approve his doctrine if it should win the approval of the scientific world. But it would have been a very sanguine evolutionist that should have anticipated what we have actually seen. For the opposition to the new doctrine was at first very stiff and hard, not only from the theologians but from the scientists. Doubtless the scientific opposition was largely theological. It was atheistic, the new doctrine; it was materialistic. If it were true there was neither a divine soul in the miverse, nor an immortal soul in man. Neither was there any adequate sanction for the moral law. Five or six years after the publication of "The Origin of Species," Darwin had no hope that he should live to see the general approval of his thought by scientific men. But he was happily disappointed. Not only so, but he was buried in Westminster Abbey. That meant that Orthodoxy had come round, as well as Science, - not all of its inert and purblind bulk, but a fair proportion of its leading spirits. Since then the accessions have been much increased. A single volume embraces the favorable conclusions of a dozen different theologians of marked ability. It must be confessed that in these examples, 
which fairly represent a very general relation of enlightened Orthodoxy to the doctrine of Evolution, there is a great deal of bad accommodation. On the one hand the science, on the other hand the religion, is wrenched from its most obvious meaning. So it has been at every stage of reconciliation. The reconciliation has been often very superficial. And often there has been no reconciliation; only a giving over of the fight, after which the theologians have gone on very much as if nothing had happened. There has been no such revision of theology as is demanded by the progress of scientific truth. The average pulpit talk is wholly out of keeping not only with the cloctrine of Evolution but with the Copernican and Newtonian astronomy, the antiquity of the Cosmos, of the Earth and Man. At the same time it is evident that the protest of the theologians has not been wholly irrational or in vain. It has often forced the party of science to a revision of its statement, and still oftener to a surrender of certain hasty inferences from its main positions. This also must be said, that the religious feeling which has inspired rnuch of the most strenuous opposition to the successive generalizations of science of the highest. rank has been entirely sound. It has been a variation of the hymn, "Nearer my God to thee, Nearer to thee." The Copernican and Newtonian astronomy, and the geological and anthropological doctrines of the antiquity of the earth and inan, have seemed to put him further off. The doctrine of Evolution has seemed to do not only this, but to impeach the dignity of human nature. The dignity of human nature has rightly seemed a more important article of faith than the origin of men from anthropoidal apes. I honor those who have opposed the generalizations of science until they have been proved compatible with a large and generous and inspiring thought of God and Man.

Are the generalizations of Darwin and of Spencer thus compatible? I am aware that Darwin's generalization is but a single illustration of the scheme of universal evolution which Spencer has endeavored to unfold, but it is such a characteristic illustration that I shall not apologize for confining myself to it very largely for a time. What really concerns us is not some isolated expression of theological opinion on the part of Darwin here or there, but the significance of his system of biology in its widest range and its completest implications. It matters little that in his. 
"Origin of Species" Darwin explicitly places an intelligent Creator at the beginning of the process of organic evolution. We wish to know if he is rightly there; if his being there is consistent with Darwin's general system. A negative answer to these questions has been very generally given by those best qualified to judge the matter. "The Creator, in the "Origin of Species," one has said, "seems introduced more for ornament than for any serious work he has to do, or at least rather to conciliate the mass of hostile theological prejudices certain to be aroused by the other doctrines than to satisfy any logical demands of the system." I put in a demurrer here. Such was the intellectual honesty of Darwin that it is not conceivable that the Creator, at the beginning of the process of Evolution, in the closing paragraph of the "Origin of Species," was any cake to Cerberus. It was a survival in culture, a relic of the mechanical English tradition which is so conspicuous in the theological speculations of John Stuart Mill. But it is true that the Creator of Darwin's closing paragraph, which caused the widowed heart of orthodoxy to leap for joy, has nothing to do at the beginning save to endow one or two primordial forms with the lowest degree of elementary life, leaving the rest to natural selection and the ordeal of battle. And he has had nothing to do ever since (on the earth at least) but sit passively by and watch a law which executes itself without any need of interference on his part. "He is a monarch that reigns but does not govern."

However satisfactory such a God as this may be to a word-mongering Orthodoxy, it can hardly be satisfactory at this stage of human progress to any thoughtful, much less to any religious person. We must have more of God than such a scheme allows, or less will be preferred. Only by not thinking much about it could Darwin have obtruded such a foreign element into the structure of his thought. That he did not think much about it is evident from the Biography. He was too intent upon the immediate task in hand to concern himself much with its relations to a general scheme of thought. A mechanical Creator, "impressing laws on matter, breathing life with its several powers into a few forms or into one" (these phrases are his own), is as repulsive to our purest science and philosophy as a mechanical Creator engaged in the special creation of vari- 
ous species. Of Darwin making this concession, the high gods of special providence and miracle may well declare, "He has become as one of us." He differs from them only in degree. He has not escaped from the region of mechanical ideas. The God who "impresses laws on matter" and breathes life with its several powers into a few forms or into one, is a very near relation to the God who originates species by special creation and performs the various miracles of the New Testament. He is the same sort of God. And if his appearance in the closing scene of Darwin's drama of existence is not without due warrant, then Darwin did no more for us than to establish the probability of natural selection within certain empirical limits. Within these limits the probability is less for his allowance that there is an ontlying sphere of special creation; and beyond these limits the God of special creation, special providence, anthropomorphic action, miracle, is still at large. If Darwin's God, impressing laws on matter and breathing life into a few forms or into one at the beginning of the process of organic evolution, is the true God, there is no reason why any one should not be a Darwinian in his biology and a supernaturalist in his theology, believing in the miraculous birth of Jesus and in his resurrection from the dead.

To this complexion must we come at length? Is Darwin's natural selection only a patch of new material on the faded supernatural garment of the Deity? It were a lame and impotent conclusion. We thought we had a rule and we have only an exception. And we are obliged to question whether the last state of Darwin's follower is not worse than the first. Special creation has been eliminated from his scheme of vegetable and animal forms. In place of this he has the laws of Reproduction, Inheritance, Variability, Struggle for life, Natural Selection entailing divergence of character and extinction of less improved and weaker forms. These give a real explanation in place of an empty name: special creation, an algebraic $x$, the sign of ignorance, incapable of conveying any definite or indefinite idea. Some of their details are marvelously beantiful; others are harsh and terrible. It is something to have knowledge in the place of ignorance; a real explanation in the place of a mere word, big sounding,-meaning nothing. But is it a sufficient compensation for the expulsion of the living God from all the countless ages that have elapsed 
since that dim early morning when he breathed the breath of life into a few forms or into one; for the thrusting back of Deity into that infinitely distant past? I doubt it very much. "There is a grandeur in this view of life," says Darwin. Here speaks the specialist, enamored like Pygmalion with the perfection of his own completed work. But to us occurs, just in the measure that we are not merely scientific but poetic and religious, the sorrow of Pygmalion that this completion is devoid of life. We sympathize with the opposition that has always met the astronomer, the geologist, the biologist, who has been engaged in pushing: back the line of the divine activity into a remoter past. It has not been irrational. It has been the soul's cry for a real presence, a Deity in the present tense, no mere I was, but the great $I \mathrm{am}$. True, there are those whom Darwin's original Creator of a few primordial forms grieves and offends, not on account of his remoteness and insufficiency, but because even then and there he seemed superfluous, matter per se with nothing of Divine propulsion, or inherent spiritual force, being, as they conceive, sufficient for the cosmic work. But such are few compared with those who least of all things dread too much of God; whose hearts' desire is answered by no far-off mechanician delegating powers to certain primitive forms, only by One of whom they can affirm, -

"He dwells above,

With scarce an intervention; presses close,

And palpitatingly, his soul over ours.

The everlasting minute of creation

Is felt here. Now it is as it was then.

His soul is still engaged upon his world."

Moreover, these camnot conceive of laws impressed on matter. Here as in the case of special creation, we have mere words. Matter without laws is inconceivable. They are no stamp put on. Their dye is in the wool. They are the constant methods of the Immanent and Universal Life.

Do I seem to criticize and condemn where you expected only admiration and assent? But my criticism and my condemnation are not for the real Darwin, the Darwin of a thousand nice experiments, ten thousand careful observations, hundreds of brilliant generalizations, all contributing to the establishment of one mighty law; they are for the Darwin of a few ill-considered phrases at the conclusion of 
his book, on which the Orthodox have pounced as eagerly as an ant upon an aphis, covetous of that drop of limpid juice, so pleasant to their taste. These phrases, which Orthodoxy has more highly prized than all the oceanic deep of thought on which they are a bit of flying foam, count for just nothing with the unbiassed student seeking to penetrate the actual significance of Darwin's speculation for religious thought and life. A mechanical Creator, no matter how remote, stands not in the order of his thought, which suggests no fragment of organic evolution set in a frame of anthropomorphic creation, but a process of organic evolution that is co-extensive with the range of universal life. Creation by law, evolution by law, development by law, these are apologetic and consoling phrases which imply a God external to the world. From Darwin's proper self they have no warrant. His deepest thought echoed the song of Goethe when he sang,-

\section{"What were a God who sat outside to scan}

The spheres that 'neath his finger circling ran?

God dwells in all, and moves the world, and moulds ;

Himself and nature in one form enfolds."

The point at which the scheme of Darwin has most obviously traversed the scheme of natural theology as expounded by Bell and Paley, and a host of equally ingenious writers, is that philosophically known as teleology (i. e., the doctrine of ends), more popularly as the argument from design. But it ought not to be forgotten that this argument, which was once equally satisfactory to Thomas Paine and his most Orthodox opponents, did not by any means wait for the appearance of Darwin to bring it into disrepute. Physics was still enamored of this argument when metaphysics demonstrated its intrinsic worthlessness. Kant never did a more effective piece of work than his arraignment of the argument from design, - the physico-theological argument he called it,-_ for the being of a God. But though the Transcendentalists left the watch-maker Deity of Paley wounded and half-dead by the way, it must be allowed that Darwin has not played the good Samaritan. He has finished what the Transcendentalists began. It is not merely that he has shown up the absurdity of the egotistic presumption that all things are designed for human comfort and advantage, a presumption of which the travesty, "cork-trees for corks to bottle our champagne," is not more absurd than the bona- 
fide teaching that fleas are made black in order that, contrasting with the whiteness of our linen, we may catch them the more easily. It is that he has also shown how much there is of animal structure which is not useful to the animal. Certain rudimentary organs are the most obvious illustration. Such are the teeth of whales that never cut the gums; of certain birds also; the wings of various insects that are never opened or used; the caudal vertebræ in man, the appendix vermiformis in the intestines, a trap for vagrant substances which, once there, proceed to organize an attack of peritonitis on the adjacent tissues. The special creationist, the Paleyologian (if I may call him so) confronts these facts with a theory of icleal types. The Deity is represented as adhering to a general plan, though the adherence is not always useful and is sometimes in the way. A Deity proceeding in this way has been aptly compared to a conservative coach-maker who, for the look of the thing, sticks a sham pistol-box upon his coaches when the reality is no longer needed. And then, too, it might be asked, "Would not a God 'so anxious for the type' have brought it out in the majority of cases rather than in a small minority?"

But there are those, and they are very earnest and intelligent, for whom supernaturalism and anthropomorphism have no longer any charms, to whom Darwinian Evolution presents the sinister aspect of a universe that is born of chance. What if the variation at this or that moment had been quite otherwise, and yet such that, seized upon by natiral selection, it would have attained to paramount importance. Then, instead of this cosmos that we have, thero might have been a very different cosmos; instead of this man-kind, a very different kind of leading race,-some mute, inglorious Jumbo, high advanced and conscious top of all. There are those who answer that the variations have been determined, that the development has been controlled, by overruling mind, to certain ends. But this answer begs the question, and brings back the extra-mundane God, tho watch-maker of Paley. Yet if there is no answer, the religious ontcome of the evolution doctrine is very poor indeed. Better, a thousand times better, for the religious heart, a mechanic God, a God of interference, special providence and miracle, than a universe devoid of purpose, an aimless drift and swirl of things. Grant that the argument from design, 
the teleology of Paley, is dead and buried past all hope of resurrection. But a teleology is clemanded not only by the religious heart, but by the reasonable mind. 'This it is, if nothing else, that sings, "They reckon ill who leave me out."

There is always wisdom in the inevitable speech of men. What men cannot help saying is as sure of being at least roughly true as what they deliberately affirm. And men, the men of science, cannot help affirming purpose of the world of vegetable and animal forms. Take Spencer's definition of Life - "the continuous adjustment of internal relations to external relations." Adjustment is a word as full of teleology as an egg is full of meat. What is adjustment but "a change in internal relations, as a means, to effect a correspondence with external relations as an end"? Again when Haeckel speaks of "the internal formative tendency" by which inheritance "strives to keep the organic form in its species," he gives himself away to teleology twice over in a single phrase - first in the word "tendency," and second in the expression "strives to keep." Spencer and Haeckel can be convicted of unconscious teleology in a much more effectivo way that by the marshalling of teleological phrases in which Darwin's works are also rife. Theirs is avowedly a mechanical theory of evolution. Their universe is a machine. But a machine is never an end in itself. If it were we should still have an end. It is a means to an end. Indeed, not only does the mechanical Evolution of Spencer and Haeckel give us a teleological universe, but it also gives us an extra-mundane God, for there never yet was a machine that made itself. Mechanical Evolution signifies a mechanic God. Well, better so than a universe without purpose, without "toil co-operant to an end." But given the principle of organic Evolution, given the idea of the universe not as a mechanism but as an organism, and we have everything we want, a God who dwells within, enfolding in one form himself and nature and a universe that is as full of purpose as the Spring is full of life. In so far as the Evolution of Spencer and Haeckel has been convicted of mechanism, it has been, I am persuaded, convicted of a fault. Mechanism and Evolution do not go together. Organic Evolution is the sign by which science and philosophy and religion can together conquer for themselves a glorious victory and an abiding peace. In 
the words of Dr. Abbot* (not of Plymouth Church but of the Church Universal), the author of "Scientitic 'Theism," "While the mechanical theory proves itself utterly unable to explain its own fundamental concept, that of the machine, and much less that of the organism, without calling in the assistance of the teleological idea which it claims to reject, the organic theory finds in this very idea the 'open sesame, of philosophy - the rational and real unity, not only of all organic facts, but of all facts whatever; and it shows that. teleology, so far from being overthrown by the fact of Evolution or the theory of Darwin, is the only principle which renders either Evolution or Darwinism philosophically intelligible. It is, in truth, the only principle which lights up the universe from within, and renders it luminous and transparent, so to speak, from centre to circumference." This is no bringing back of Paley's God. The teleology of Organic Evolution is not the old fashioned teleology which sought to find in every statical arrangement a proof of wisclom and beneficence. It is a teleology of dynamics, of tendencies. It is "immanent in the universe as its omnipresent thought and life, not external to it as that of a mechanical Creator, working in material alien to or other than himself." Here is no aimless drift, destructive of all faiths and aspirations of religion, but a tide that sweeps forever through the universe of matter and of men in the direction of the 'True, the Beautiful, the Good.

Darwin entered upon no discussion of fundamental problems. Like Voltaire's Candide, he was too busy tending his garden, listening for what the earth-worms had to say to him and the trailing plants. Orthodoxy, covetous of his fame, has easily convinced herself that he was no materialist. She has his word for it - a God impressing laws upon matter — in the last paragraph of the "Origin of Species." But it is impossible for any intellectually serious person to follow up the process of organic development as described by Darwin in his various writings, and arrest his feet before the verbal barrier opposed to him in a single place. The rush of the great argument carries him through and beyond this barrier as if it were a wisp of straw. He cannot give good heed to the immense induction, and after all believe that organic evolution is a part and not the whole. Every experiment arranged to test the problem of spontaneous. 
generation may as yet have failed to prove the fact. Future experiments may be as unavailing. But while the first instance of special creation is not only undiscovered but inconceivable, the suggestion comes with overwhelming force that the transition from inorganic matter to organic life as little needed the interposition of an extra-mundane God as the transition of our April into May and June. The objection to materialism could not be too strenuous, so long as matter was regarder as something which, without inherent mind, could build the cosmos and the thought and love and pity of mankind. Nay, let the separate atoms be as alive and pushing as you please; grant them not only chemical affinities, but each a brain compared with which Newton's or Plato's were an imbecile affair, and who shall deem that they could so put their heads together as to produce the present universe. "The divinity is in the atoms," as the seer hath told; but it is in them not as distinct in indivichalities, but as a pervasive and cohering unity.

I can easily imagine that more than one malicious humorist has said of this course of lectures upon Evolution, "As I passed by and beheld your derotions, I found an altar with this inscription, "To the Unknown God." Not merely the worship of the unknown, but of the unknowable, is supposed by many persons to be the only worship that Evolutionism allows her votaries. It is a lamentable fact that Herbert Spencer is himself unknown to the majority save as the prophet of the Unknowable, a distinction as little to be envied as that accorded to Harriet Martineau, when it was said by some irreverent person, "There is no God, and Harriet NIartineau is his prophet." For Spencer's doctrine of the Unknowable is the least characteristic and least valuable part of his entire performance. In his "First Principles" he has made it the propylæum to the temple of his thought, but its architecture is conceived in an entirely different spirit, and it only serves to keep us back from what is worthy of our admiration. It is as metaphysical as Prof. Davidson could wish, as metaphysical as Sir William Hamilton's "Philosophy of the Unconditioned" and Mansell's "Limits of Religious Thought," to which it immerliately succeeded, inheriting the weakness of their philosophical method. With Hamilton and Mansell, he insisted on the unthinkable and consequently unknowable character of all the primary concepts of both Science and Religion. It is 
astonishing how generally this aspect of Spencer's doctrine has been overlooked. It is an aspect that relieves it of all those dreadful consequences for which it has been held responsible. For however unknowable the ultimate concepts of science, we have Mr. Spencer's Biology and Psychology and Sociology to show us that we have no lack of scientitic knowledge. If so much scientitic knowledge in despite of fundamental ignorance, why not as much religious knowledge? There is nothing in the conditions of the problem which prevents this happy consummation. No one need be troubled by the assurance that an unrelated Absolute would be inapprehensible, that an unmanifested Infinite could never be found out, "in a universe full of visions and of voices." Starting from his doctrine of the Unknowable, Spencer proceeds to bring about the reconciliation of Science and Religion. They are reconciled by reciprocal confessions of an equal ignorance. Now I trust I shall not be thought presumptuous if I say that I cannot conceive a more senseless and ridiculous reconciliation than this. If I am thought presumptuous I can only say that I am so in the best of company - that of as good a friend and loving an interpreter as Mr. Spencer ever had - Prof. E. L. Youmans, who wrote, "the terms of compromise he proposes are dishonorable to both parties, no less so to science than to theology." "Not what is most abstract but what is most concrete in each is the basis of the final and harmonious adjustment. * * Spencer, in the result he has reached, does more to help forward this adjustment than in the basis he proposes. When he gives us the demonstration of Science that all phenomena are the result of one absolute and ommipresent power, we see the first step in the process of reconciliation. Science will demonstrate the fundamental truths of religion, while the extravagance of theology will be corrected and its confusion made clear by the same process."

'The doctrine of evolution is not Mr. Spencer's private property. He has not determined just what it shall or shall not be for all time. Other men had labored and he entered into their labors, and did more than any or than all who had preceded him. Others have entered into his labors and done great and glorious work. It is one of the most capable of these-Prof. Fiske - who writes, "The Doctrine of Evolution asserts, as the widest and deepest truth which the study of nature can disclose to us, that there exists a 
Power to which no limit in time or space is conceivable, and that all the phenomena of the miverse are, whether they be what we call material or what we call spiritual phenomena, manifestations of this Infinite and Eternal Power." Whatever fulness and richness of statement there is here that we seem to miss in Spencer's reconciliation of science and religion, there is nothing that has not come out in subsequent expansions of his thought. And surely there is no lack of knowledge here. We camnot know anything aright without knowing it of God. The old claim of theology to be Scientia Scientiamum, the science of the sciences, was never made so good before as it is now. And it is what we know that makes the vast Unknown the boundless continent of religious sentiment and aspiration. What makes the vast Unknown so quickening to our awe, our gladness and our trust is that what we do know is so wonderful, so marvelous, and we proceed to people all the great Unknown with the benignant forms and forces that have been openly revealed to us. When Charles Lamb was fifteen and Mary twenty-six, they saw the sea for the first time, and were not a little disappointed, because they expected to see "all the sea at once, the commensurate antagonist of the earth." But when we stand on the sea-shore, is it, as he said, only "a slip of salt-water" that we see? or only

"Eastward as far as the eye can see Eastward, Eastward endlessly The sparkle and tremor of purple sea"?

It may be ail we see, it is not all we feel. Surely what fills us with a joy so keen that it is almost pain is not alone the flashing tumult of the great expanse of waters; it is also that, beyond where sky and water meet, with the mind's eye we see the ocean reaching on and on, beautiful with the same unspeakable beanty that lies within our fieid of actual vision. It is the beauty of the known that makes the beanty of the Unknown so sure and so entrancing. And just as surely the soul's normal delight in the infinite God is not produced by any merely negative unknown. No more is it by any positive known. No, but by the warrantable conviction that all the infinite unknown is, equally with what we know, the haunt of beanty, order and majestic law.

Known as an infinite and eternal energy, known as the 
source of everything that is, known as he manifests himself in all things we can see or hear or apprehend in any way with sense or mind, the God of Evolution does not invite to wonder and to mystery alone. He does invite to these with a persuasion that grows every day more irresistible as the unknown is shot through and through with gleams from that great sun of knowledge which is mounting steadily our morning sky. But he invites no less to those attitudes and beatitudes of mind and heart which $\mathrm{Mr}$. Frederic Harrison, that eloquent apostle of the Religion of Humanity, declares to be the best religion has to give"love, awe, sympathy, gratitude, consciousness of dependence, reverence for majesty, goodness, creative energy and life." The religion of Evolution is not, in the phrase of Mr. Harrison, "a religion only to stare at." It is a religion which sends us forth to work for higher truth and better service among men.

What word has it concerning immortality? The most encouraging that any system of philosophy or science has yet offered to the world. Much of the difficulty that Evolution is imagined to suggest was just as palpable before the time of Darwin and Spencer. If man has descended from the ape and the ascidian, were they also immortal? If not, when did immortality become the privilege of the individual? But there is no difficulty presented by the clevelopment of man from lower and the lowest forms, which is not presented equally by embryology. The embryological history of the individual resumes the development of the race. Beginning with a germ which cannot be distinguished from that of any animal or plant, he passes through fish-like and ape-like stages until he emerges a "radiating, jaculating fellow," monarch of all he surveys. At what stage of this development is the gift of immortality bestowed? The difficulty is every whit as great as that presented by the development of the species. There is no slightest proof of immortality; only a slowing that the ascent of man from lower forms adds nothing, as it is very commonly supposed to do, to our embarassment. Meantime our embarassment is seriously lessened by our appreciation of the fact that in the course of cosmic development we have had the organic produced from the inorganic, and we have had the self-conscious produced from the unconscious. In either case we have, apparently, a greater leap 
than from self-conscious life to immortality. We can only say that there was a time when favorable internal and external conditions struck out the spark of life; as further on they struck out the spark of self-consciousness. Again, no scientific doctrine not part and parcel of it has allied itself so firmly with the doctrine of Evolution as the doctrine of the conservation of energy. But if the conservation of energy be indeed a law, if it was all the way through the world of matter and of spirit, then somehow and somewhere the souls not only of the mighty ones of intellect and imagination but of humble folk whose names are soon forgotten upon earth are enabled to resume their conscious individual life. Again, one of the most significant and impressive aspects of the general scheme of Evolution is that of correllated growth. In the development of animal structures there goes along with the development of special organs, parts and functions, the development of certain others adapting them to changed conditions. Now in the spiritual life of man there goes along with the development of all that is best in his intelligence, noblest in his affections, grandest and sweetest in his moral life, the development of the hope of an immortal life. Here is a correllated growth; and if the hope that is thus developed is not a valid hope, if it is not a solemn and majestic portent of a divine reality that we can trust with calm assurance, then have we a radical contradiction in our moral nature, increasing there with every higher thought and nobler act and purer purpose of our lives. If the almost invariable concomitant of the noblest living is this glorious hope, then, unless nature's house is radically divided against itself, this almost invariable concomitance suggests with overwhelming seriousness that the same Power which organizes in us the purest splendors of our thought and love, organizes in us the hope of an immortal life in which these splendors shall go shining on forever.

The formula of Evolution is the survival of the fittest. I know that by "the fittest" in this formula we are to understand merely the fittest, i. e. the ablest, to survive. But if the significance of the doctrine of organic Evolution resolves itself into this identical proposition, it is a truism that was hardly worth the patience of Charles Darwin's toilsome years. Unless this doctrine can assure us in its widest scope of the survival of the ideally fittest, the fittest to carry 
on the work of Evolution to yet grander heights of beauty, use, and joy, its intellectual magnificence is the merest mockery of its moxal imbecility. The development of free personality in human life has been so far the crowning work of Evolution, the crowning work of God this sid` of death, and I take it he did not blunder into it, that the creative purpose set this way before the singing of the morning stars. We have here, I know, the survival of a species, not the survival of the individual after apparent death. And if we could be allowed the vision which we once enjoyed, of Humanity upon the earth advancing endlessly to an ever-greatening, never absolute perfection, we might be tempted to be satisfied with this. But when science comes. as Mr. Serviss came in this course of lectures a few weeks ago, to tell us that the climax of Evolution will be the destruction of the earth and of the solar system, and finally the resolution of all the starry heavens into "a gray, wide, lampless, dim, mpeopled world," she comes bringing a fresh argument for an immortal life. Only so can we have any true survival of the fittest. I cannot believe that all this travail of the ages will only bring to birth another nebulons cloud, another formless universe. I must believe that it has brought to birth a universe of souls, whose continuous and exalted life will justify the long gestation of the world, and justify the blotting out of every star that shines in the high vault of heaven. I cannot see why we should stultify ourselves that we may justify the ways of God. White may be black, sweet may be sour, right may be wrong to other faculties than ours. It is only by our own that we can judge, and judging by our own, "Without Spirit-immortality," as Le Conte has said, "the cosmos has no meaning. * * Without Spirit-immortality this beautiful cosmos, which lias been developing into increasing beauty for so many millions of years, when its evolution has run its course and is over, would be precisely as if it had never been - an idle dream, a tale told by an idiot, signifying nothing."

From treating the ethical aspect of my subject, which is not the least important, I am discharged by Dr. Janes's clear and impressive presentation of this aspect a few weeks since. I will only say that there are those who claim for ethics a religious source and aim and imagine that in doing this they are antagonizing the philosophy of Evolution. But never has a system of ethics heen conceived that is 
more fundamentally religious than the system of a consistent evolutionist. "For clearly," as John Fiske has said, "when you say of a moral belief that it is a product of Evolution, you imply that it is something which the universe through untold ages has been laboring to bring forth, and you ascribe to it a value in proportion to the enormous effort it has cost to produce it." "The Evolutionist is not talking rhetoric, but science, when he declares that the distinction between right and wrong is rooted deep in the foundations of the world. When Wordsworth, in his "Ode to Duty," sings :-

\section{"Thou dost preserve the stars from wrong}

And the most ancient heavens through thee are fresh and strong," he is not more poetical than scientific. For the same unending genesis that evolved the original nebula into suns and stars has wrought into the inmost substance of the universe the principles of right and wrong. "Human responsibility," as Prof. Fiske has said, "is made more strict and solemn than ever when the Eternal Power that lives in every event of the universe is seen to be in the deepest possible sense the author of the moral law that should guide our lives, and in obedience to which lies our only guarantee of the happiness which is incorruptible - which neither inevitable misfortune nor unmerited obloquy can ever take away."

It is no ghost of a religion which appeals to us with thoughts and sanctions such as these. It is a veritable religion, "capable of affecting human life by acting on the human spirit" as no substitute for religion can do, even one so high and noble as the so-called Religion of Humanity. For it not only gives to moral sanctions

$$
\text { "an equal date }
$$

With Andes and with Ararat,"

but, seeing that the moral law is rooted in the foundations of the universe, the universe is moralized by this perception; the infinite dark of the unknown orbs itself into a Sun of Righteousness with healing in its wings.

"Thus he dwells in all

From life's minute beginnings up at last To man.

So in man's self arise

August anticipations, symbols, types

Of a dim splendor ever on before." 


\section{ABSTRACT OF THE DISCUSSION.}

\section{Rev. Merle St. Croix Wright:-}

I believe that the doctrine of Evolution, contrary to the general fear, really re-enforces the idea of God. The perception of an order in the universe is an evidence of God in the universe. There must have been a cause to start the universe - to begin the process of evolution. Speeulation as to this eause is beyond science, and belongs to philosophy. There is no room in the universe for chance. Nature presents a grand spectacle of material order, man of moral order. Our idea of God must cover both. Evolution, therefore, shows God with us, though in a different way from that in which he was formerly supposed to be with us; hence the opposition to the new thought. Law is an expression of method, and method involves purpose, intelligence. The scientists appear to be coming around to the idealistic position. Professor Cope holds that there is a consciousness in all things, and that this develops at last into man's self-consciousness. From this is developed, on a scientific basis, the idea of immortality. The brain is simply the machine of the mind, which does not perish when the brain dies. Evolution, therefore, leaves the three fundamentals of religion untonched: the belief in God as the author of law; in the soul as an inclividual entity; and in the immortality of the self-conscious soul. Evolution shows the adaptation of means to an end. It transfers the idea of design from particular fact to general principle. The Divine is still necessary to account for man's thought and capacity for progressive development.

\section{Professor Jerome Allen:-}

I stand before you as a staunch Presbyterian and yet a firm evolutionist. I could agree with much of the essay-perhaps most of it-- but will present one or two points of possible disagreement, bearing upon the relation of Evolution to Christianity. There are two kinds of natural religions - those which are moral and those which are immoral in their influenee. But Christianity I believe to be an exception to the general rule of evolution, being an extranatural product. If I was convinced that Christianity was a product of Evolution, I should not be a Christian. I would define religion as a sense of dependence on an external power. Any one who feels this sense of dependence on an outside Power, has a 
religion. The earliest religions did not help man to right action, but the reverse. Religion does not always make us better, but sometimes worse. It is often dissociated from morality. The religions of Zoroaster and Gantama were examples of moral, those of Mahomet and Joe Smith of immoral religions. But Christianity is not an evolution from anything before it: it is a revelation. The Christian religion was not a development of the Jewish religion, but a thing suigeneris. It is as nearly as possible the direct opposite of the Jewish religion. The Christian religion brings the soul into organic union with God. This differentiates it from all other religions. The Christian is united by a mysterious process with the personal soul of God himself. If it could be established that. Christianity is an outcome of purely natural forces, Christianity would pass away.

\section{Rev. D. W. Morehouse:-}

I camnot agree with the position taken by the last speaker. The doctrine of organic evolution places religion on a firmer basis than ever before, because it proves it to be a natural and universal requirement of the human mind. According to the last speaker, there was no true religion before Christianity. This compels an unworthy conception of a Being who is assumed to exercise a. fatherly care for all his creatures. That there has been an evolution in religion is almost self-evident, and that Christianity is the finest flower of this evolutionary process is almost equally selfevident. Instead of doing away with Christianity, the demonstration of the truth of Evolution in all its bearings will cause a further evolution in Christianity, placing religion on a still nobler plane than it has heretofore occupied.

\section{Dr. Lewis G. JANes:-}

Ny own investigations have compelled me to a conclusion precisely opposite to Professor Allen's, as to the nature of the Christian religion. To me it appears one of the mostadmirable illustrations of religious evolution. Its essential elements are not, indeed, all inheritances from Judaism, but they grew naturally out of its intellectual environment. No assumption of the supernatural is necessary to account for the origin or development of Christianity. While agreeing with nearly everything in $\mathrm{Mr}$. Chad wick's admirable essay, I cannot quite regard as valid his criticism of the doctrine of the Unknowable. Accepting Mr. Spencer's psychology, his doctrine of "transfigured realism" naturally grows out of it. We have, according to this conception, a world of phenomena 
which is infinitely knowable, but which is symbolical only of the Absolute Reality which lies behind phenomena, and of which the human mind can take no direct cognizance. This region of the Absolute - this substantial Reality underlying both sense-perception and consciousness, is the Spencerian Unknowable. Spencer may, as Mr. Chadwick assumes, have unconsciously appropriated some of the metaphysics of Mansel and Hamilton; but if we aceept a psychological foundation even more realistic than his, which I am inclined to do, I do not see how we can get entirely rid of an Unknowable Reality. Take the lowest organisms, for example, with a single, vague, undifferentiated sense of feeling or apprehension of external reality. They are manifestly shut out from a vast field of knowledge which is possible to us. To them, this is a part of the Unknowable. Man is limited to five senses - five avenues of approach toward the external world. Each of these senses is limited in its scope or range. Must we not, therefore, admit that there is an External Reality - knowable perhaps per se, but unknowable to man because of the limitations of his sense-perceptions? The recognition of this fact seems to be forced upon us by science itself, and its acknowledgment appears to me to be an essentially religious act of the mind.

\section{Mr. Chadwick:-}

I have no time, at this hour, to follow Dr. Janes into the clistinctions between the unknown and the unknowable, in which $\mathrm{I}$ think he may have taken valid ground. Speneer's later writings lave been inconsistent with the disreputable compromise between science and religion which he proposed in his "First Principles." I could not altogether agree with Professor Allen as to the immorality of Mahometanism. At the time of its origin it was an improvement upon the Christianity of the East, and in competition with that Christianity it has steadily prevailed. Nor can I accept his distinction of moral and immoral religions, in the broad sense in which he drew it. Immorality is an incident of all religions, even of Christianity. This chureh has had the reputation of being heretical, but I am glad to say that the worst heresy ever uttered here lías come from a Presbyterian professior! Christianity not an evolution from Judaism! Why, we have Jesus' own word for it that it was : "I am not come to destroy, but to fulfill." Indeed, it seems to me that the Jews of our time, the more liberal of them, are nearer to the religion of Jesus than are the popular forms of Christianity. 


\section{THE PHILOSOPHY OF EVOLUTION}

\section{$\mathrm{BI}$}

STARR HOYT N̦ICHOLS

Author of "Moyte Rosa, or the Epic of AN Alp, - A POEM." 


\title{
COLLATERAL READINGS SUGGESTED
}

\author{
IN CONNECTION WITI ESSAY XIV.
}

Spencer's First Principles and Psychology; Fiske's Cosmic Philosophy; Thompson's System of Psychology; Martineau's Types of Ethical Theory; Perrin's Religion of Philosophy; Abbot's Scientific Theism; E. D. Cope's Origin of the Fittest, and Evolution and Idealism (in Open Court, No. 23); Stallo's General Principles of the Plilosophy of Nature, and Concepts and Theories of Modern Physics; Lewes's History of Philosophy; Huxley's Lay Sermons and Critiques and Addresses; Winchell's Speculative Consequences of Evolution; Comte's Positive Philosophy; Writings of Frederic Harrison. 


\section{THE PHILOSOPHY OF EVOLUTION.*}

The Evolutionary Philosophy is the latest born of time. Not that it has been undreamed of in the cogitations of naturalists and speculators from ancient days, but that as a credible and established system its currency is very recent. Its acceptance may be said to date from after the publication of "The Origin of Species" by Charles Darwin, in 1859. And though it now assumes the air of a philosophy in rank with the oldest and most honored systems, yet is it in no way descended from any former system of philosophy, nor even in its origin does it show relationship to them. It was not born of their stock nor connected in their lineage. It has not the blood of their ancestors in its veins. It is rather a gypsy philosophy, born of nature under the hedges. It comes not of thought, but of fact; not of spirit, but of flesh. Plato had no glimpse of it, and Aristotle would have regarded it not as philosophy proper, but rather as a kind of mechanic generalization having no claim to place beside metaphysics and ethics. It is not derived from the new Platonists, nor from the scholastic philosophizing of the church and the Middle Ages. It has no derivation from Kant, though Kant, outside of his "Pure Reason," stretched hands towards it; nor from Spinoza with his technical and tedious demonstrations; nor from Descartes with his tautological cogito, ergo sum; nor from Hegel with his vast umbrage of logical sequences; nor did Hobbes or John Locke, or the Scotch psychologists, or Hume or Sir WVilliam Hamilton, nor even d'Holbach with his system of Nature, nor Auguste Comte in his Positive Philosophy, ever get well upon the track of the doctrine and philosophy of Evolution as we know and hold it to-day.

Rather did it make its entrance into the world from quite another parentage than that of the so-called philosophers of the old schools. For, while they were dreaming and arguing, other men were examining and proving the things of the material world about them; and so it came to pass that Lamarck the botanist, and Laplace the astronomer,

* Copyright, 1889, by The New Ideal Publishing Co. 
and Draper the physiologist, had perception of the truth which all the grand metaphysicians in their reasonings had clearly missed.

Of this fatherhood, the Evolutionary Philosophy got its geniture; and being itself an evolution not from Philosophy so-called at all, but from Science, it unexpectedly grew to be a philosophy, to the signal discomfiture of all the previous professors of that lofty pursuit. And being thus basely born it manifests the difference of its origin and blood by turning its hand against all of the ancient systems, itself a reckless Ishmaelite outside of the old Israel, accusing them of being false pretenders to knowledge and claimants of wisdom which they never possessed. For there is no philosophy hitherto so-called whose dicta it does not bring in question and whose conclusion it does not put on trial for its life.

Now the Evolutionary philosophy in its simplicity is merely a statement of what we see about us on all sides and at all times. As a philosopher the Evolutionist looks about him and sees that the universe of to-day is the result of the universe of yesterday, as yesterday was the result of the day before that; and argues that all our yesterdays were in like manner the products of the days preceding them. And so he reasons, in like manner, that all tomorrows will be the product of their predecessors, with never an alteration in the everlasting procession. And then, widening his view, he declares that the method of the universe always has been and always will be exactly the same as we see it about us, one thing changing into another by a restless and unintermittent procedure of which he can discover no beginning, nor the chance of any end.

'This is saying, in effect, that this present world is a sample of the whole universe, and this present time a sample of all eternity; that our present knowledge is the same in kind with all the knowledge that ever was or ever will be, to the last syllable of recorded time. Here and now we have all there is of everything, at least in outline, and though many things will be discovered in the future which are beyond our ken at present, yet will all future discoveries be of the same general nature with what we know to-day. They will be part and parcel of the evolution of nature, along lines of cause and effect such as are familiar to every one now from his early year's. 
This position is the same in philosophy with that of Lyell in Geology, which has reclaimed Geology from a dreamland of eataclysm and monstrosities to a world of sane and familiar forces, whose effects we know and can study in actual experience. It is the same position as that secured by Newton in astronomy, when, by discovering the law of gravitation, he dismissed the angels of all the planets, once supposed to guide their revolutions round the sun, and substituted instead a calculable law sufficing for every emergency. And the position rests upon the principle which goverus all reasonable thinking, of which the law is to study the known and from it to learn what is likely to be the nature of the unknown, on the ground that the universe is all of one piece and one order, and that there is no call for any other order or law but only for the one, and that one the one we already know. And the Evolutionary Philosophy therefore insists that the more one studies the method of the world about him - the present and living facts of existence - the more sure is he to judge aright of the whole universe and to be able to conceive the farthest range and scope of its most distant possibilities. It looks down with light scorn upon the assertions and propositions of those who philosophize upon possible worlds with no detailed comprehension of this world, who assert unverifiable propositions of many sorts without having mastered verifiable propositions enough to steady their minds and give poise to their judgment.

Now this assertion of the scheme of the universe as resembling in its utmost reach what is known of this world here and now, is based upon no less a matter than the complete testimony of all the studies which men have been able to make and verify respecting things everywhere. All the sciences have been consulted in the formulation of the dogma. Astronomy, geology, botany, zoology, embryology, the utmost discoverable antiquity of the past, the widest diversity of the present, things most alien and separate, things of the largest and those most minute, the secrets of chemical action, the farthest flight of comet and star, the viewless behavior of unseen atoms and the movements of invisible forces, all have been taken into council and made to bear their witness. Nor has the verdict been rendered till each one had spoken and given his free word; and there is no dissenting voice among all of them. The doctrine of 
Evolution is simply the widest generalization of all facts, gathered from remotest orbs as well as from the gases about us and the grasses beneath our feet. It is a declaration of the procedure of the present from the past, of the future from the present. the statement of belief that this was always so and always will be so, and that the universe is complete and self-regulating under the control of this principle.

Being thus a generalization from natural facts, the Philosophy of Evolution does not need to borrow weapons from old reasoners or books of the past. It asks nothing of nominalist or idealist; it shows scant respect for metaphysician or logician. It has little to say to the old disputants about "cogito, ergo sum," or the essence of being, or the thing in itself, or the ontological proofs of the existence of God. When reading the metaphysical philosophers, one is fain to be persuaded that important interests for humanity are bound up in their conclusions; but Evolution brings one to his sober senses and discloses the habit of trifling which metaphysical stuclies give to minds devoted to them. As an example, consider how many hours good minds have wasted over Kant's "Critique of Pure Reason," with its. fruitless propositions. What is the use of reasoning as to whether space and time have only formal existence or also real existence, excepting as an exercise of ingenuity? It is a pretty piece of chess-playing, perhaps. And all his learned discussions as to how a priori judgments are possible - as if there were any such reasonable judgments and the like, are they aught but mere excursions of curiosity, worthy of attention only from those who have no serious pursuits? Evolution, not having been rocked in the metaphysical cradle, gives cool recognition of these and similar studies. It merely calls attention to the fact that either side of their questions has no material proof, and therefore lacks in the first condition of a verifiable proposition.

The wide difference of methods existing between the Metaphysical and Evolutionary Philosophies is seen nowhere more forcibly than in the systems for discovering truth employed by the Transcendentalist, Hegel, and the Naturalist, Darwin, respectively. Both were men of extraordinary intellect, of great industry, of pertinacious devotion to their ideas, of wide range of investigation, and comprehensive 
statement. But Hegel sat down in his study and gave his days and nights to profound reflections on abstract Being, and the course of nature as a course of thought. He then developed a series of abstract, verbally logical sequences, on whose lines he affirmed the universe to have been laid down, and expounded them with awful toil and subtlety. His main principle of the identity of contradictions proved as barren as other metaphysical discoveries. The reasoning was cogent, the proof by definition (if definition could ever prove anything) was convincing, but still nothing ever could grow from it all. Verbal propositions can produce only verbal progress, and verbal progress is like Mr. Carlyle's spavined horse, "all move and no go."

As if to make the futility of metaphysical investigation - even if its principles were true - the more startling, Hegel's dialectic had the advantage of being itself evolutionary in its form and spirit. One proposition springs out of another by a surprising derivation, resembling a real parentage and sonship as closely as words can resemble the facts of the world. But it proved to be valueless all the same - for thought can never have the value of things, except when it represents things exactly. It is otherwise but a baseless fabric of vision - the cloud-world of the maybe, not the land of the real. One might go on entertaining its theorems for centuries, as happened during the ages of scholasticism, and not a step forward for the welfare of mankind would be made in consequence.

Compare this whole procedure with that of Mr. Darwin in his endeavor to discover the order of nature. Not in the closet, nor in his own mind, did he fancy that he could find the principles of the universe, but only in nature herself. To nature, therefore, he applied himself, made a voyage of study round the world, seeking everywhere the material facts and procedure of things, comparing and sifting verities with tireless industry and for many years, until his main proposition of the transformation of species was established. Then he enlarged his theory and disclosed the everlasting mutation of the restless universe, the instructive and fruitful law that anything may become anything else if its material basis is properly handled. And this philosophy brought, at last, the long fumbling of the metaphysicians to an end. Never again could their endless logomachy interest sober minds. Never again could they 
maintain the supremacy of their industry or its claim to be most worthy of human attention. Their ghosts and hobgoblins began to scatter and fade in the growing light of the new dawn. The emptiness and muddiness of their writings began to be visible to their most devoted adherents. The Darwinian fact made the Hegelian fancy look pale and thin as the formless air.

And this was further elucidated by the wonderful books of Mr. Herbert Spencer, who carried the evolutionary doctrine and its method of investigation through all the old haunts of the metaphysicians, and showed what mines of knowledge the new method could disclose, full of the silver and gold of truth, where before men had perished in bottomless quicksands or quagmires of speculation. For under his masterly handling the physical or physiological basis of many an ancient doctrine was exposed for the first time, and the material truth of which the metaphysical dogma had been the confused and disconnected statement was brought. to light and set in its due place in an evolutionary universe. Then both the adherents and the opponents of various dogmas were angered and dismayed, to find that their contention was a chaffering about husks and shells, while the kernel of the matter had been claimed or known by neither. What the Philosophy of Evolution required of the metaphysicians was real proof for any of their assertions, and this demand it was which brought their windy quarrels to quietude. They had no real proof, and soon it became clear that they never could furnish any. They had been furnishing verbal proof, on both sides of interminable questions, for centuries, but real proof in the actual working of the universe there was none, and they could therefore bring none forth. And when Evolution came forward, offering to demonstrate by bare facts a multitude of propositions all going to verify its own main principle, no wonder it arrested the attention of all and drew disciples in crowds from the schools of the old teachers. For it at least furnished a standard of truth, which the former had failed to do after ages of painful industry.

And the main difference between Evolution and all preceding systems is perhaps most of all in this, that its adherents. can verify their assertions by a standard of proof, whereas. the metaphysicians are still unable to do so, as they have no standard, and therefore every man says that which is. 
right in his own eyes. The evolutionist appeals to fact, the metaphysician to thought, with the advantage to the first that the fact remains while the thought perpetually changes.

A special illustration of the superiority of this Evolutionary appeal is seen in its application to those fanatics of wilfulness and hap-hazard, the Intuitionalists. These thinkers, of whom Ralph Waldo Emerson is the anointed high-priest and oracle, were disporting themselves like dolphins in the high seas, amid what they claimed to be high themes, showing an originality and brilliancy of expression unrivaled. So long as they were not called upon to establish any of their assertions, they were very successful, and astonished the empyrean with the splendors of their rhetoric and the lustre of their paradoxes. Who could surpass Mr. Emerson in the courage and kindling fire of his discourse? Who could seem nearer to nature and the true order of nature than he? He held his audiences and readers enthralled, as he seemed to open to them the loftiest heaven of thought and to clisclose all the secrets of spirit and spiritual worlds. But the arrow of evolution, alas! takes him also in its winged flight,- - him the beautiful Achilles,- and glancing strikes the vulnerable tendon of his heel with fatal effect. For what the Philosophy of Erolution undertook to do was, as I said, to prove its positions with the amplest evidence. It would listen to everything, but accept nothing without demonstration. It had no ears for glittering generalities. It would have chapter and verse from the Bible of fact for any proposition which the arrested Intuitionalist might be inspired on his tripod to deliver. This threw a coolness over the industry of those venturesome and guileless thinkers, which we fear will deepen as time goes on. For surely the grasshopper-like flight of their thoughts is calculated to bring them nowhither. They spring into the air and come down wherever God wills. But Evolution, as a doctrine, builds a solid causeway of proved truth through the trembling swamp of hmman conjecture wherein they wander,- - a causeway over which the nations of the future may march to ever-increasing power, wisdom, and happiness, as long as the world inay last.

The Positive Philosophy, so-called, of August Comte, has something to say to Evolution, and claims many of its doctrines and benefits for its own. In so far as it induced 
men to leave the pathless woods of metaphysics and mythology for the cleared land of science it of course deserves the laudation of philosopher's; but it came far short of discovering the fundamental postulates of evolution. It was itself metaphysical and fragmentary. It was so little familiar with the true method of philosophizing that it at last landed its believers in the paltry and time-wasting cult of its founder's mistress, and in a Religion of Humanity which is good enough for an ideal but has no roots in the nature of things. It elevates a sentiment to that throne of authority which fact alone can satisfactorily fill. Positivism played an excellent part in its insistency that a philosophy should deal with the universe itself rather than with various notions about the universe. It deserves a magnum cum laude for pointing out the unsatisfactory service rendered by metaphysics. But it was only a door to the method of nature, and not that method itself.

Leaving now the other systems to their own intrepid adherents, let me say that the Evolutionary Philosophy seems to me to be essentially materialistic. It is true that its greatest apostles, Spencer and Huxley, and Mr. John Fiske as well, allege that of the two world-old dilemmas between mind and matter, every analysis leads rather to the conclusion that we know the universe far more as all mind than we do as all matter. They do indeed deny that we can claim to know its real nature at all, and so sustain themselves in the airy spaces of agnosticism, declaring the existence of "an Unknowable Reality" beyond our ken. Mr. Spencer labors the point frequently, asserting that consciousness and reason alike fail to carry us beyond a knowledge of relations, which never disclose the absolute reality. The permanent substratum of mental being, which abides behind all the changes of thought, and the permanent substance in which all the qualities of matter inhere, must forever remain hid from us. But if we were to decide anything as to the nature of the ultimate substance, he says we should clecide it to be mental rather than material, for consciousness itself is nearer to mind than it is to matter, so far at least as we see it internally. All our knowledge is declared to be.given in units of feeling at last, and these units of feeling are mental. We seem thus to be crowded back to the old metaphysical basis for all philosophizing the primitive testimony of consciousness. While one may 
well pause before entering the lists against Mr. Spencer, yet one is also daunted at finding himself planted on a metaphysical bog for the foundation of a physical philosophy, and therefore he may make a shift to get foothold elsewhere.

And perhaps he may find such foothold in the position that the units of feeling seen in consciousness are really only units of force (which are recognized as the ultimate elements of the external. world), seen under a subjective transformation effected by nerve-sensibility. In confirmation of this he may at least point out that knowledge, so long as it was discussed as composed of units of feeling, was sterile of results and incapable of progress. Only when it began to be viewed as composed of units of force did it become useful and open to an endless development. As an example of this we may cite the futile and umprogressive study of the nature of mind when conducted by the method of introspection, or looking at one's feelings, after the manner of philosophers preceding the last half century. Much was said and written by them, all to small purpose. Mind was as little disclosed as matter, and of neither was there much real knowledge. Introspection merely kept turning round and round in its own bushel-basket at home. But no sooner did mind begin to be studied as itself a form of matter, as an external object and a part of physiology, than light began to appear and knowledge to advance. Significant is it also, in this connection, that Mr. Spencer's luminous exposition of the composition of mind borrows its lucidity from the author's constant recurrence to the phenomena of matter and material action. It might indeed be called an exposition of mind considered as included in the forces of material nature. In other words, though he insists upon mind as being ultimately composed of units of feeling, he expounds it as if it were composed of units of force.

And this is in fact the method to which all men of science are driven at last. Though consciousness gives only feeling as its experience, and perception as the result of feeling, and though this be asserted to be the internal and primary testimony of consciousness, yet no sooner is this proposition laid down than the barrenness of it begins to be felt, and the faithful internal psychologist is immediately hurried forth to say that these units of feeling appear also 
somehow as units of force in other connections, and must be treated as such in every use which is made of them in verifying truth or discovering knowledge. So that we may perhaps embolden ourselves at last to question the ultimate character of the feelings as such, since each of us has only a single witness to their existence, and that is his own consciousness; and we may rather regard these feelings as merely a subjective or special form of units of force, just as sound is a special form of units of motion. They seem to us at first to be units of feeling existing only in ourselves; but in everybody else, these same feelings can only be observed as units of force, and the corrected statement would therefore appear to be that feeling is merely a transformed force. In other words, we correct our internal experience by the larger generalization of our external experience and arrive at a basis which is at once universal and fruitful. We arrive at the true accomnt of our feelings by an outside knowledge got through them, which, generalized, shows that they are but one other form of the universal units of force. Here at last we pass over from a barren introspective psychology to a fertile external universe, which includes the introspection as one of its countless manifestations.

Consciousness is thus found to be as misleading in its primitive reports about itself, as about most other things. Regarded from within it seems to be what is called a spiritual or immaterial faculty, moving about the spaces of the brain with the speed of light, and through the senses cognizing the universe. So subtle, quick, sure, lucid is it that nothing less than the attributes of a God are deemed sufficient to characterize its nature, and it is said to be "made in the image of God." But regarded from without, how different is its aspect. This Godlike apprehension is discovered to be absolutely dependent on a brain and various congeries of nerves, which are mere material substances. No brain, no consciousness; and this fine, internal, lordly self-appreciation is reduced to the modest character of a function of a grey pulp, which the blow of a hammer or a failure of blood-supply can reduce in an instant to complete insensibility.

The external observation thus corrects or even subverts the internal testimony. The apparently immaterial mind is forud to hang upon the material brain as the odor of a 
rose hangs to the flower. Both are a sort of exhalation. And the changes in that brain, under various environments, embody the whole immense variety of modern knowledge, whose works in the world are but a magnified magic-lantern picture of slight alterations of grey brain-matter within. The solidity and certainty with which this various knowledge verifies itself in practice gives the strongest possible proof of the correctness of the premises from which it all springs, viz., that units of consciousness are more properly estimated when regarded under their corrected form as units of force, than under their primary form of units of feeling.

Perhaps both of these units may be best harmonized in one unity as forms of motion, as most ably set forth by Mr. Raymond S. Perrin in his book on "The Religion of Philosophy." Mr: Perrin's criticism of Mr. Spencer's position seems to have striking validity, and to demolish the necessity for supposing some "Unknowable Reality" back of all knowledge, on which $\mathrm{Mr}$. Spencer so stoutly insists. Motion, as the dynamical aspect of matter, seems to furnish all the materials necessary to compose the universe. Matter in motion becomes the fountain of all things, and thought is but brain in motion, as life is but atoms in motion, and knowledge is simply an active participation in the infinite motion of the universe.

But if one be inclined to insist upon the testimony of his own individual consciousness, and to posit mind as immaterial because he feels it to be so, we can only bring to bear against him the fact that in so doing he plants himself upon one single experience - his own - against all the rest of his knowledge, which is that of observation criticised in detail by all that others know, and the whole course of nature in its daily movement. It takes but a moment's reflection to see that this last accumulation of testimony affords a basis for certainty of a universal character, such as never can be afforded by the weak testimony of our single consciousness, which is and must always remain isolated and alone to each one of us. It was dependence upon this which led the world of men in a fire-fly dance after phantoms through ages, and still leads most tribes. It is this which gives us a Chinese civilization in one place and a Hindoo in another, and Feejis in a third. It is this which gives us ten thousand sects and cranks of every hue. But. 
a distrust of individual consciousness, on the other hand, forces us to the wide comparisons of modern science, and the trustworthy conclusions on which all instructed men agree. And on this the Philosophy of Evolution rests,not on what feeling says, but upon what corrected feeling finds to be true of the units of force.

of course this doctrine is dowmight materialism; but then the doctrine of Evolution seems to many and probably really is materialistic to the core. Nor need this be deemed strange when we recall that this Philosophy was first discovered in the material world. It was found among the fowls of the air and the beasts of the field. It was cradled in the manger where cattle were feeding. It had for its murses the naturalists, and it was brought up at the hearthstone of physical science. And its stronghold and playground is still the material world. Because it places suns and planets in their orbits without hands, because it arranges the strata of the earth without design, because it traces the genesis of crystal, plant, animal and man, step by step without break and without miracle, it is accepted, and only because it does so. Were it not for its incontestable familiarity with the history and ways of material nature, the spiritualists would long ago have remanded it to the dirt from whence it sprang. But it holds to its visible facts, snaps its fingers at metaphysical disproofs, and riots in its tangible demonstrations, now become so profuse and allconvincing. It finds no need for ratiocination, for here is the daily process of nature repeating its propositions and enforcing its philosophy upon all men. And if there is any work of God which is his incontestably, it is this same Nature which furnishes such proofs to Evolution, and sustains its head amid the querulous complaints of idealists, spiritualists and dreamers of every feather.

But having been so born, of materialistic parentage, nursed by materialistic students, reared among materialistic studies, and crowned by materialistic proofs, it seems hardly likely that it can now be sustained in any other than materialistic relations. Vain is it to try, as some do, to marry it now into the fine old family of spiritualism* in order to give it credit with minds still loyal to the old opinions, and ready to fight to the death for the old flag which has flaunted

\footnotetext{
* The word Spiritualism is here used to denote the advocacy of Spirit as an immaterial somewhat, distinct from latter.
} 
over so many desperate battle-fields where nothing was won but wounds and death. The Napoleon of a new era, it cannot usefully mix its fresh blood with the outworn royal Austrian of ignorant days.

And truly, that the evolutionary philosophy is materialistic is, to my mind, nothing against it. Nor is it that I have any special antipathy toward the opposing idealistic or spiritualistic hypothesis. The only interest I have in either depends simply upon their truth and usefulness, but especially upon their usefulness. I an willing to receive any benefits from any source, and if spiritual or idealistic philosophies have anything to give, I am glad to avail myself of their help. But they have held sway over man for ages without adding serious advantages to him. They prevailed in Christian countries to the exclusion of all materialism up to the beginning of this century, and seem to have misused this time greatly. They did not arrest war, nor banish slavery, nor diminish intemperance, nor check bigotry, nor abate superstition, nor prevent persecution or tyranny. In fact, while they were prevailing the world dragged on, weltering in miseries, the prey of plague, pestilence and famine, a coward before ghosts and fairies, the easy victim of every natural accident, servile to kings, priests and sorcerers, and devastated by perpetual fears. There was small progress in thought, slow advance in knowledge, fanciful standards of proof, little stability in propositions, slight discoveries in the methods of Nature. One reads the records of those bewildered and disputatious ages with astonishment that men could ever have been content with such futilities and barrenness. Spiritualistic theories were lifting their heads on all sides like a ring of serpents, each hissing its contradictions and anathemas at the others. There was little enough in the results of this devotion to idealistic fantasies to make one desire a restoration of its reign.

How much thinking,- - how little welfare! Would it have addled any great benefit to the world if most of the questions respecting the Trinity, the nature of the soul, the nature of duty, the exact authority of conscience, the nature of space and time, or the like, had ever been satisfactorily settled? Scarcely! for it is of these questions, pre-eminently, that Lessing's remark is true, that the pursuit of truth is better than the attainment of it. There 
was and is but little in the questions excepting the value of the discussion of them as sharpeners of the intellect,- the same empty-handed benefit which is noisily claimed for the medireval college curriculum of to-day, on which our youth are still tediously trained. Were it not better to have done with futilities? Why go on whipping for trout in streams long since robbed clean of fish?

It is therefore with impatience that one hears the reiterated lament of public teachers and preachers over the tendencies of the age towards Evolution and its materialistic ideas. One would imagine, to listen to these wailers, that there was something blighting in materialism; that its marked increase, during the last thirty years had been attended with great injuries to the human race. Whereas, if one will only consider the matter fairly, this last period has seen more advance in human well-being than all the last 2,000 years before it. Materialism has prevailed, and has made a new world out of a sad and worn-out one. The progress has been in material forms, in railroads and telegraphs, in cotton-gins and steam-driven machineries, in an immense increase of wealth and luxury, in books and newspapers, in applied science and philosophy, which makes man handier, shrewder, more industrious, - averse to war, tyramny, superstition, narrow-mindedness, gloom, disorder and poverty.

If materialism has so many advantages to confer, why should we be afraid of it? Why should we not rather be afraid of that spiritual philosophy which spent two thousand years in discussing the nature of God and the soul, and human destiny generally, and duty as an abstraction, leaving mankind meanwhile hungry and cold and naked, the prey of disease, and the prisoner of physical and moral ills? And what insistent and blind folly it is to be warning the age against the dangers of a materialism whose highest word has proved to have more good sense and clear light in it than ever fell to the lot of the best idealistic discussion that literature records, from Plato down to James Martineau! Why go on cultivating the profitless sands of Sahara, when the hills and valleys of Materialism already rustle with the corn and vines whose fruits are for the gladdening of the nations?

Even from a spiritualist's point of view this material 
philosophy is more profitable than spiritual methods. For the spiritualist's clamor about duties and high aims and altruistic living, and the like, is best met and satisfied by materialistic methods. It may easily be shown that the enormous intercourse of nations and continents produced by modern commerce has done more to promote these virtues of toleration and charity than the apothegms of Epictetus and the sermons of Chrysostom. A merchant-ship bears more than its cargo of meats or grains or goods; it bears also the good-will and friendly regard of those who trade with each other for gain. The armies of the Christian Powers do not so well defend those Powers against their enemies as do the commercial relations of their subjects one with another. And if the meddling, selfish dynasties were abolished, and all custom-houses as well, commerce would, far more than benevolent sentiments, make one peaceful confederacy of German, Russian, Frenchman, Italian and Spaniard, in less than a century.

So also the steam-engine, by facilitating travel, has done more to destroy bitter distinction of race and religion than devotion to ideal questions could do in æons of time. For, in the first place, idealistic discussions can touch but few, being the pursuit of the learned; and in the second place, personal contact with strange peoples and other religions dissolves prejudice as the sun dissolves dew. By reason of travel, the false and bitter slanders of one nation on another, of one church on another, have been disproved and destroy'ed.

And a similar moral benefaction has been conferred by the mere multiplication of books and newspapers by the material printing-press. It is not possible for vested wrongs, for ancient and established ignorances, to maintain their places before the merciless fire of the daily papers. No artillery has such precision and range as the batteries of the Hoe press. No adjurations to do justice and love mercy have or can have one-half the power to realize their desire as these engines of attack on injustice have to compel both to be done. How many rogues have they brought to justice, how many crimes searched out, how many prevented, how many good causes established! How long could a Czar maintain his Siberian horrors under the steady exposure of a daily press, repeating its incessant denunciations day by 
day within his dominions? And the press is the child of materialism. It prints its sheets for gain. In the dialect of the street, it is pushed to make money.

In the uses of machinery, too, we may vaunt the praises of materialism in its plainestaspect. Mr. Matthew Arnold, in his pleasant way, depreciates our devotion to machinery, and would rather have us use the freedom of the spirit as the better method. And he attacks the whole manner of modern advance, and sings the praises of mere culture,"hearing and reading the best things there are going," as the Greeks of Plato's time are falsely supposed to have been doing for the most part. But it is quite certain, to anyone who has an open eye to the world, that machinery has done more to transform the world to something like Plato's ideal Republic, in one century, than all the unmechanical centuries for twenty-two hundred years had done before. Machineries of steel and wood create machineries of moral and spiritual movement as well, and furnish irresistible agencies to promote public virtue such as never before existed; and the more machinery, the wider spread is virtue. Who ever heard of a savage tribe, without machinery as they are, as able to do anything worth doing except for mischief and destruction? Mr. Amold himself remained but as the "wandering voice" of the cuckoo in the glades of society, because his ideas could not organize a machinery for their propagation among mankind at large. Material embodiments are more than lofty expressions, and the church itself is great, more by its machinery, than by its ideas. A new machine for traveling by telegraph would enlarge the human mind more rapidly than all the colleges and book-learned author's in Christendom can do.

Machinery forces men to become exact, punctual, regularly industrious, and sober. It compels them to study the properties of materials, to learn new truth constantly, and conform themselves to it. Men become more observant under its tuition. The commonest factory-girl has her dull and aimless mind somewhat quickened and focused by the precision of its work and the exactitude it demands of her. It turns the vagrant savage into a thoughtful artisan, makes an Ericsson, an Edison, a Bessemer, an Eifel, possible, and is so far from degrading men to its level that it raises them immeasurably. Think of saying that a Digger Indian is degraded to the level of a Corliss Engine! The engine is 
already far his superior, and worth more to humanity. Machinery always elevates its employers.

See how Materialism also makes men more truthful than Spiritualism. When men can be brought to an exact bar, and proved to be false, they are perforce more guarded and careful in their statements. Such a tedious falsehood as that of the Roman church, that bread and wine are the true body and blood of Christ, which has debased the minds of believers for ages, could not hold its sway for an hour under a materialistic philosophy. No more could the Platonic doctrine that ideas have real existence outside of the brain. Men do not attempt to lie in mathematics, except when they have some spiritual theory to maintain.

So, too, we may sing the praises of a materialistic philosophy in that it absorbs the energies of the age in the pursuit of wealth. Never before was mankind so well engaged. It is better to build passenger steamers than men-of-war. It is better to build factories than cathedrals. It is better to build railways than armories. It is better to develop mines than to promote missions. Men are seldom or never so well engaged as in making money decently. Six days are not too much for profitable labor, though one day be enough for worship, even according to Moses.

Why, then, should we hear, from our more spiritual friends, a great outcry against this excellent pursuit? For it is easily seen that, since the world began, mankind was never so well engaged in general as it is at the present day. "T'he mad race for riches" leads to enterprise, education, good health and long life. It keeps men out of mischief and crime, it covers the earth with great cities and the water with great ships, it spans the rivers with bridges and fills the air with voices of intelligence, it makes famine impossible, and binds with fetters of self-interest the bloody wolves of war. Thatever is good among men is largely the effect of wealth, whether it is reckoned in material goods or the advances of charity, peace, justice, science, art, or politics. And the wide difference between our own peace-loving age and its gainful occupations, and the quarrelsome and destructive ages before, is chiefly due to the fact that now men are all seeking wealth through industry, instead of advancing religion by persecution, or patriotism by war, or politics by lies and force, or power by intrigues and assassinations. 
Friends of the spiritual philosophies who exhort us to think more of their vague propositions, and to devote ourselves to God, immortality and duty, should reflect upon the awful miseries which befell those who formerly were devoted to such pursuits, neglecting their bodies and worldly interests the while, till a horror of great confusion overtook them like a flood, and swept them down the wreck-filled current to ignorance and death. 'There has never been a better age than the present, since man has written history; and the simple reason is that man has now become materialistic in his aims, - has turned from the bloodless spectres which he formerly pursued to active care for mere flesh and blood, to houses and lands and inventions and enterprises and splendor and display, and whatever makes life more fruitful and more abundant in material goods.

Materialism, which is represented as a flood that threatens to drown all higher impulses, proves to be rather a Nileinundation, whose waters bear the fertilization of humanity. And yet mediævalists would have us return to the dreary pursuits of the spirit, where men wandered for centuries living on manna and water!

The opponents of Materialism, in their devotion to spiritual philosophies, display many curious moral obliquities calculated to impair a mere materialist's confidence in their principles; - as where we see them eager to sacrifice hekatombs of other men, and human welfare, to the establishment of their ideal visions. Look, for instance, at the idealist, Temnyson, who voices in his "In Memoriam" the tenderest and most reverent sentiment of the age respecting God, duty and immortality, and afterwards lets himself rave, in "Maud," to praise and glorify the multitudes of blameless youth slain in that worthless and even then antiquated barbarity, the Crimean War,_- becanse "Gods's just wrath would be wreaked on a giant liar," and "a peace that was full of wrongs and shames" broken up in the awful carnage of battle. As if we should say it is better for men to kill each other in rage and hatred than to cheat each other for gain. As if murder was not by far the greater crime!even if one does call it war and treat it to the luxury of poetry. Materialism looks at things quite differently and cloes not exhort us to begin killing men as a better pursuit than cheating them. Materialism has its faults, but it 
seldom loses it head or waxes enthusiastic over crimes greater than those it attempts to cure.

So much then, we may say in reply to those who are afraid of Evolution because it is a materialistic philosophy. As the immense body of modern knowledge, in all its vast variety, is knowledge of the properties and actions of matter, it can be safely left to defend itself. That mankind will ever leave it to go back to the groping leadership of metaphysics or the pursuit of the elusive mirage of socalled spiritual truth, there is not the remotest possibility. Like the statue of Liberty in our glorions bay, the materialistic philosophy of Erolution will lift up its electric torch over umumbered generations of the future, scattering the white light of its all-illuminating truth over land and o'er sea, and over the ever increasing knowledge and happiness of all wise and free nations. 


\section{ABSTRACT OF THE DISCUSSION.}

\section{Mr. Raymond S. Perrin :-}

When asked to criticise a lecture upon the Philosophy of Evolution, to be delivered by Mr. Starr H. Nichols, I anticipated, in accepting, a pleasure, because I knew the lecturer was capable of dealing with the subject. I knew that he had familiarized himself with the general logical results of the doctrine of universal filiation or descent, so fir:nly established by the investigations of Charles Darwin; and I knew also that he had applied this doctrine to the phenomena of mind or consciousness, which is pre-eminently the realm of Philosophy. I must confess that I have been disappointed. The lecture has closed without any explanation of the nature of mind.* The argument lias been confined to a very interesting account of the materialistic theory of society. The humanizing influences of modern industrial development have been pointed out. We have been shown how industrial progress produces socidl progress. The lecturer has also emphasized the universality of physical law, pointing out how it repeats its operations with divine uniformity in all time and space, bringing into interdependence and into fundamental similiarity all the systems of the universe, and he has declared boldly and distinctly that the prime power in all this is not spiritual but material. We can only admire the courage of the lecturer in making this assertion, for the reason that it is so unpopular. The great majority of religiously inclined persons are repelled by the assertion that matter can explain everything to us. They feel instinctively that such a philosophy is coarse, that it lacks sublimity, and as philosophy is largely a matter of definition I must confess to a sympathy with the religionists in their aversion to materialism. For matter is not the ultimate fact, it is only an aspect, the statical or restful aspect of universal activity, or life, and if a name must be given to the pliilosophy of evolution which shall distinguish it, once for all, from the religious or supernatural systems, I think that name should be the vital not the materialistic philosophy. For Life is the universal fact, and Evolution teaches us that all phenomena, whether physical or spiritual, are forms of life. This vital principle is not unknowable, for it is the simplest of all experiences ; it is the first element of knowledge. In mathematics it is called motion, in physics force, in biology life, in psychology mind, in

\footnotetext{
*In justice to Mr. Perrin, it slould be remarked that to the lecture in its present form, as revised ly the author before jrinting, this criticism would not strictly apply.
} 
religion spirit, or intelligence, or God. All these diverse terms involve ultimately the union of space and time or of the infinite and the absolute. The chief advantage of the Philosophy of Evolution is that it can explain the connecting link between mind and matter, by bringing into interdependence intellectual and physical phenomena, by explaining the point of contact between the spirit and nature. This harmony of thought and feeling is what the religionist most longs to comprehend, for it alone can bring peace to the mind, it alone can dispel the contradictions which arise between the belief in a divine love and the evidence of a suffering humanity. The ultimate analysis which harmonizes the meaning of our most general terms is a logical fact, which appeals only to a class of specialists, but this analysis, so necessary to philosophy, can be explained in the language of every-day life. There is no limit to its applications and to its simplifications, and it will be found to be the key to the Philosophy of Evolution. In Language we have the connecting link between the intellectual and the physical. Language is a natural development, beginning in rude sounds and gestures, and progressing in perfectly comprehensible steps from the expression of concrete experiences to that of general principles. In this vast development, resulting in the creation of literature and science and philosophy, there is no interposition of the miraculous or the supernatural, and all the mysteries and superstition of religion can be shown to result from infelicities of speech, the lispings of primitive races, which have reached us through tradition; the efforts of undeveloped language to voice the abstract truths of life. The greatest feat of language is the discovery of a single term to represent divine unity, the formation of the ultimate generalization. The Philosophy of Evolution has had its beginning in the great discovery of Darwin, who revolutionized zoology by establishing the mutability of species, by proving that organic life is a single family, developed by natural agencies from a few primordial types. This theory he completed by including in zoological classifications the species Man. He neither attempted to show the filiation of the lower organic activities with chemical and physical actions on the one hand, nor on the other to show the relations of higher organic life with the phenomena of mind. Darwin, therefore, was not a student of the mind. He was a naturalist as distinguished from a philosopher. It is to such men as Meyer and Helmholtz, who discovered the correlation and equivalence of the physical forces, and to such men as Spencer and Lewes, who have established the interdependence of the organic and the mental forces, that we owe the exten- 
sion of Darwin's great theory of the Descent of Man into a philosophy of evolution; and $I$ think that in neglecting the mental aspects of the subject, the lecturer has lost an opportunity of making a symmetrical presentation of his great theme. In the narrow limits of this criticism, it is possible only to suggest the vast proportions of the theory of evolution. For humanity the central fact of evolution is the nature of language. In language we have the connecting link between mind and matter, the agency which has raised man to the position he holds above other related orders of living beings. Language is thought, language is sympathy, language is interaction. In comprehending its nature we command the true perspective of existence, we reach the zenith of intellectual life. Its categories of perception and expression are universal. Gravitation and affinity and love all lead to and explain it; even in the cold, clear atmosphere of thought its metaphors and symbols bear out the endless analogy. The verb, the symbol of activity, is the soul of language, the central fact in every sentence, and all the other parts of speech denote simply the times and places of the action or being. The sentence is the molecule of thought; it is complete in itself, containing all the elements of being. It is the sentence which transforms facts into symbols, it is the sentence which enables physical life to rise into intelligence or spirituality. This is the ultimate analysis. It shows how social development is primarily expressed in the growth of language, which renders mental and moral development possible. It shows us that mind and spirit are not ultimate facts, but aspects of Life, and that Life means Evolution.

\section{Dr. Robert G. Eccles:-}

In the lecture and the criticism we have an illustration of the danger of looking exclusively on one side of a problem. The materialistic mind looks only at the static side, and sees that alone; the spiritualistic mind looks only at the dynamic side, and fancies that is all-inclusive. Mr. Nichols and Mr. Perrin represent two kinds of evolutionists: the one materialistic, repudiating the ideal; the other idealistic, repudiating the material. Each has a halftruth, and each needs the other to supplement and complete his own view. But the Unknowable is the true basis of the whole subject. The philosophical doctrine of the Unknowable is not concerned with knowledge that can ever be known. The phenomenal universe is infinitely knowable, but gives us no hint as to the essential nature of Absolute Being. As the scientific problems lying at the basis of this discussion are largely questions of physi- 
ology and physics, one needs to be a physician in order to comprehend them. Matter in its outer aspects is knowable, in its ultimate aspects is unknowable. Matter and force are not what they appear to be to the senses. A feather is brushed across our hand. We say, "The feather tickles." But this is not true. The tickle is in us, not in the feather. Color is not in the objects we see around us, it is the effect produced upon our brain by an inconceivably rapid vibration of the rays of light proceeding from the object. Sound does not exist apart from the hearer; if there were no hearer there would be no sound. We can acquire knowledge of how the universe affects us, but not of the universe itself. We know that there is more than matter and motion in the universe. There is Nind and Being, which cannot be explained in terms of matter or motion. As to the identity of evolution in other worlds with that in our world, assumed by Mr. Nichols, the theory of evolution, which shows that all things tend continually to differentiation, requires that there should be diversity instead of identity in the development of life on other planets.

\section{Mr. Dudley Blanchard:-}

The evolution of mechanics is one of the most important phases of the whole subject under discussion, and I am glad to see it at last touched upon, by the present lecturer. I rise merely, as one interested in mechanical pursuits, to thank him for what he has said upon this topic.

\section{DR. LEWIS G. JANES:-}

As to the beneficent character of the material progress of which Mr. Nichols has spoken, I am wholly in agreement with him. That this, however, is all there is of the Philosophy of Evolution, I cannot agree. In all this discussion, we are questioning about what we can know. Now, fundamental to all such considerations, is the question: What is an act of knowing? What is consciousness? If wholly a subjective process, unrelated to material conditions, then it is difficult to escape from the conclusions of the Idealist. If wholly a product of material conditions, then we must follow Mr. Nichols. But if, as I believe, it is subjecto-objective, testifying at once to a thought-process which cannot be expressed in material terms, and to the reality of an external material world, then we must either rest in this Dualism as an ultimate and unexplainable fact, or go forward to a monism based upon the doctrine of the Unknowable. Mr. Nichols says we see thought in other men only as brain-motion. Now, I never have been so fortunate 
as to see the brains of other men think. I should like to have him explain how this can be done. To me, as to Spencer, IIuxley, and other evolutionists, the passage from the physies of the brain to the phenomena of thought is something inconceivable.

\section{Mr. Nichols:-}

Dr. Janes's position seems to be fruitless and unsatisfactory, because he never gets to anything ultimate. He must go on and on, always questioning and never getting an answer, instead of being satisfied to begin somewhere. It is useless to start on such a quest. We can know nothing of the ultimate nature of consciousness. [Dr. JANES: It seems that you are at last getting to the Unknowable yourself.] Mr. Nichols : Your Unknowable. What I meant to say was that consciousness is truly known just as other things are, when its internal feeling is criticised and corrected by external observation and generalized upon both. Then it seems to appear that thought as observed in others than ourselves is simply a motion of the brain, as digestion is a motion of the stomach. The Spencerians (and Dr. Eccles will pardon my saying it) are in a hopeless state of confusion over the Unknowable, and their philosophy of knowledge is built on an assumption of ignorance. The position that there is such a thing as mind independent of brain is an unverifiable one. Dr. Eceles said that one ought to be a physician to thoroughly grasp the truth of Evolution - and come out where he does. Well, there is Dr. Maudsley; he has some reputation as a doctor, and he is a materialist. What I meant in regard to evolution in other worlds, was that the method of evolution is the same throughout the universe, though the materials and special forms may be different. If we are willing to accept the ultimates as they present themselves to us, we need not chase the infinite. Those ultimates we know if we can know anything, but if we do not know them then we can know nothing and there is no use in thinking. When we step beyond those ultimates we land in "chaos and old night," where is nothing but dreams and an aimless metaphysical whirl. 


\title{
THE EFFECTS OF EVOLUTION ON THE COMING CIVILIZATION
}

\author{
BY \\ MINOT J. SATAGE \\ AUTHOR OF "THE RELIFIOX OF EVOLUTIOX," "THE MORALS OF \\ EVOLTTIUN," ETC., ETC.
}




\section{COLLATERAL READINGS SUGGESTED}

IN CONNECTION WITH ESSAY XV.

Graham's Creed of Science and The Social Problem; 'Thompson's. The Problem of Evil ; Savage's Social Problems ; Heber Newton's The Social Problem; W. I. Gill's Evolution and Progress; Francis Power Cobbe's Broken Lights: The Present and Future of Religious Faith; James Cotter Morison's The Service of Man. 


\section{THE EFFECTS OF EVOLUTION ON THE COMING CIVILIZATION.*}

If one but knew what the "Coming Civilization" is to be, it would then be a comparatively easy task to note the processes by which it is to be brought about. It is not an uncommon thing for people with an imaginative turn of mind to jump to some alluring conclusion, and then, with too little regard for facts and natural tendencies, to seek for some short cut to the goal of their foregone conclusion. And if their millennium is anything more than a pleasant. dream with which to amuse an idle hour, they not only grow very impatient of natural growth, but perhaps also somewhat violent in their dealing with all who do not agree with them. Ylato's "Republic," Sidney's "Arcadia" and More's "Utopia" may stand as specimens of ideal dreamworlds. 'Their authors, however, whether they really believed in them or not, did not intend to fight for them or in any way urge them as immediate reforms. 'The thing to be noted about them is that they were arrived at by a. purely " primri process, not deduced as the result of any observable tendencies in human history. The same is true also of the "kingdom of heaven" which Jesus preached. It does not follow, however, that these dreams were useless. Man is the only animal, so far as we know, that is haunted by an ideal. And the ideal not only hints the possible, but it also serves the purpose of creating a divine discontent with imperfect conditions and of stimulating effort towards the attainment of something better. One may not realize his dream; but he will attain something better because of his dream and of his struggle to grasp it.

But these dreams are not all ancient ones. They are more in number, and are more operative in the sphere of practical endeavor to-day than ever before in the history of mankind. 'They are not only dreams, but they are the motive-forces of crusades that have their heroes and their martyrs. The air is resonant with prophet calls and rallying-

* Copyricint, 1889, by The New Ideal Publishing Co. 
cries. Let us note a few of them, chiefly for the immediate purpose of noting how little agreement there is as to the nature of the "Promised Land" that is sought. Of course no agreement can be expected on the part of a priori theorizers. And where there is no agreement, of course there can be no common effort towards a single end; so enthusiasm and effort are wasted. It ought to teach us something then to note the confusion of the disagreement. If only an end and a method could be settled on, so that there might be "a long pull, a strong pull, and a pull all together," - in that case something might be hoped for.

In the religious world there is hardly any recognition of Evolution as having anything to do with the problem. The churches have got only to the point of reluctantly confessing that possibly it may have to be accepted as true. But, instead of putting its truth to any practical use, they are chiefly engaged in plans for making it possible for Spencer and Darwin to keep house with Moses, provided the necessity is made to appear. They are all agreed in looking for the coming of the "kingdom of heaven"; but, though they have an "infallible" authority on the subject, they are as hopelessly "at sea" as is all the rest of the world. They agree neither as to time nor end nor method. The Pope "knows" that the only hope for man is in his own supremacy. All the social evils of the age are the direct results of wicked revolt against his authority. On the other hand, the Protestants attribute most of the evils of the past to this same Pope, and are in a state of intermittent panic lest his old-time power be regained. Little can at present be expected in this direction then, except that both Romanist and Protestant will keep on preaching a theory of man, his origin, nature, condition and destiny, that science has thoroughly exploded. Until facts are accepted and realities dealt with no results can be rationally even sought after.

One of the most striking and interesting dreamers on the religious side is Count 'Tolstoi. 'The old and common claim is that Jesus is the one who has "brought life and immortality to light" ; and so the Christian ideal has been generally located in the other world. But, most curiously, while Tolstoi claims to be the one true interpreter of Jesus in the modern world, if he does not deny he at least ignores the future life, and proposes to seek his kingdom of heaven 
here and now. To this end he wonld abolish all forms of force; for the central principle of his Christianity is nonresistance. He would have no governments then, no armies, no distinctions of nationality, no legal contracts, no compulsory education, no public building of roads even. He would have no one lead any course of life that would necessitate disagreeable work on the part of any other. So he even discards linen shirts; though why it is any less disagreeable to wash woolen ones is not quite apparent. $\mathrm{He}$ regards modern civilization as all a mistake. Science, philosophy, literature, art, all are "vanity." The contented mind and the inoffensive life of the common worker for the common wants of every day - this is his icieal.

I spent a Sunday afternoon and evening last summer* with Mr. William Morris, the poet, the artist, the Socialist, of London. I went ont with him and stood by his side while he preached to a crowd on the street against the wrongs of the existing order of society. His artist soul is offended by the ugliness and discomfort of our present civilization. He has heard the cry of the London poor. Said he to me, "There are five hundred thousand people in London who do not know what they are going to eat tomorrow." This against a background of barbaric and useless splendor on the part of the nobility and the rich! It is some sort of socialistic rearrangement of the world which he seeks, that shall make labor once more the joy of an artist in his work, instead of the drudgery of a beast of burden whipped on by the lash of hunger. He rejoices in every sign of what he regards as the increasing hardship of the present system, in hope of that day when the people will bear it no longer.

One of the most completely wrought-out and fascinating dreams of the future with which I am acquainted is told by Mr. Edward Bellamy, in his book, entitled "Looking Backward." This is the ideal of State Socialism, or what is coming to be called Nationalism. The Nation owns everything and does everything. Nobody is rich and nobody is poor. With the certainty of abunclant support in perpetuity, all motive for personal accumulation is taken away. All are educated; and, though each works for the whole, and though all kinds of work are honorable, free play is still left for individual taste and personal ambition. It is 
a wonderful picture, and one wishes it might be realized in so short a time as that which the book calls for. If only ideal states of society could be voted into existence, I would gladly start out on a campaign in favor of this.

But the practical difficulty always is that the real people in the world are not the kind of people that the scheme requires, and they will not behave as you want them to, even for the sake of carrying out the most brilliant project. They are very much like the ducks in Mr. James Russell Lowell's story. I think he first told it to illustrate some such point as this. He says that his barber, having a scientific turn of mind, and having heard of the transmutation of species, got hold of the brilliant idea of changing the cheap and common duck into canvas-backs. 'These latter, being very expensive, he intended to sell for a high price and so make his fortune. Having learned, perhaps from Buckle, that almost everything depends on what one eats, he conceived the idea that by feeding his common ducks on celery he could work out his transformation and then retire from his humble trade. So he invested his small earnings in ducks and celery and fancied himself on the eve of success. But when Mr. Lowell next saw him he wore the downcast expression of one not altogether satisfied with the universe. And when asked as to his experiments, he put the result of his experience into words, - "I invested all my savings in ducks and celery. And now I don't know whether it would have turned them into canvas-backs or not, for the darned things wouldn't eat it."

That is just the trouble with many social theories. We work out on paper some clear and easy way of bringing in the millennium; but, alas! when we offer it to the people, - the real people in the streets and not the imaginary ones on paper, "the darned things" wont behave as the success of our theory requires.

I need not stop to mention Fourier and Karl Marx, the Shakers, the Oneida Community, and Brook Farm; the specimens I have given are enough for our purpose. They are all a priori experiments, not the natural results of growth. It will be noted also that some of the dreamers look towards Anarchy, the extreme of Individualism, while others look in precisely the opposite direction, towards Socialism. But all of them, anarchistic or socialistic, have this one fatal defect in common, - that they are dreams, in 
the air, out of any visible or demonstrable relation with observed forces and tendencies of which they may be regarded as the natural product. 'This is not a dead universe, but a live one; and it is moving with tremendous power in certain definite directions. We can neither ignore this movement nor oppose it. Our only hope is in co-operation with it. If we are to build a paradise it must be out of existing materials and in accordance with the laws of forces already at work. The first thing then for us to do is to find out, if we can, which way the world is moving. If it is already moving downward, growing to worse (as some zealous reformers, like Tolstoi, assert), then we might as well give up the unequal contest. The Infinite is somewhat larger than we are; and I, for one, see no great hope in tighting it. But if it is on an upward track, then we may hopefully co-operate with it; we may even hasten the coming of better days. Indeed, in the light of intelligent selection, we may attain results that otherwise would not come to pass at all. But it can only be by co-working with forces and tendencies inherent in the nature of thmgs.

I do not see how any intelligent believer in Evolution can despair. But if he be an intelligent believer, he will know that the first thing to be done is to find out which way things are tending. Before he indulges too much in dreaming, he will become a careful and reverent student of the past.

If one wishes to find out which way a river is flowing, and into what larger body of water it will probably empty, he need not be able to find its fountain head, he need not trace it clear to the mouth. It will be enough to follow a large part of its main stream and to note the trend of the great mountain-chains that define its valley. He will thus be able to gain a scientific warrant for his opinion as to which way it is going. So we may know enough of the evolutionary stream to forecast its direction out yonder under the cloud and mist that hide from us what we call the future. Let us therefore now run over the main features of the past evolution of life on our earth.

We need not try to uncover the beginning. Start with such horizontal forms of life as the worm and the fish. Very simple nervous systems had they, and very small brains. But embodied life begins to lift and climb. 'Through reptile and bird and mammal and anthropoid ape it struggles 
to the perpendicular position. At last man appears. $\mathrm{He}$ stands on his feet; he looks up to the sky. His fore-feet become hands and his cry a voice. His nervous system is immensely complex, and in brain-power he has left all competitors hopelessly behind. Physical evolution in his case has reached its limit, except that it goes on ever perfecting and refining the form already attained. The evolutionary force seized upon the brain. Though weaker and slower' than others, though he could neither fly nor swim, though without tusk or horn or claw, he yet became able to outwit all his enemies, and make himself master of the inhabitants of earth not only, but of sea and air as well. From such low begimnings have been developed the high table-lands of our general modern intelligence; and this is over-topped by the mountainous peaks that cluster about and look up to such superior heights as are represented by the names of Praxiteles and Cæsar and Cicero and Shakespeare and Mozart and Washington.

But the force of evolution did not stop with intellect. It has climbed up into the moral. And to-day the ethical ideal is mightier than all muscle not only, but all brain. It dominates the nations. For to-day there is no king or cabinet that dares openly defy it. However selfish or evil the scheme may really be, its promoters must at least put on the semblance of zeal for the general good of humanity.

And one more step is being taken. After a long contest with materialistic theories and tendencies, there is apparent a tremendous upheaval of the spiritual forces in man. It looks like an unfolding of spiritual tendencies and forces such as the world has never seen.

Parallel with this general stream of progress that we have noted, are other streams, whose tendency can be as plainly seen. In his sexual relations man has advanced from practical promiscuity, such as is found among the lower animals, through polygamy, polyandry and many modifications of both of these, to monogamy. Politically he has advanced from the despotism of war-chiefs, through all types of monarcliy, to the freedom of representative govermment, where it is recognized that all power inheres in and is derived from the popular will.

Along with all these there has been observable an indus. trial tendency as well. At first the wants of man were 
very few, and each one provided for his own. The chief business of the early tribes was war, and the daily drudgery was left to the women. 'Then, as certain tribes grew stronger, they kept alive the prisoners taken in war and made them slaves. Under these circumstances it was natural for handlabor to be regarded as degrading, fit only for slaves. And it followed from this that those who were not slaves but who were compelled to labor were looked on as but a little above the slavish rank. So they were shut off from the higher ranks of society as being low caste, or were serfs attached permanently to the soil. In either case, bound as they were by their necessities, without the means, even if they had the right, of moving from place to place, or of rising above the level on which they were born, they were practically but little better off than slaves. During the Middle Ages, the laborers, by their guilds and other associations, were able to lift themselves much above the position they occupied in the ancient world. And if agricultural laborers were practically tied to the soil, perhaps it was quite as well, for they then had no taste or fitness for travel, and so preferred the old-time associations. But when America was discovered a new era dawned for the common people. They became accustomed to the thought of change, while a wider contact with society, and acquaintance with other nationalities, developed new tastes, created more and higher wants, and so tended to lift them to a higher level of manhood. It is true that the laborers are not yet free. For while the wage-system is an immense advance on anything the world ever knew before, the man who must go into the market and sell all the hours of every day in order to live, of course cannot travel or study, or develop a taste for what are rightly called "the humanities," the higher sides of life. There must be some wealth, some leisure, for these things.

To this point then the world has come. Those who allow their impatience at remaining evils to run away with their judgments, to the extent of asserting that the wageearner's condition is growing worse instead of better, show one of two things: either that they are ignorant of the facts, or that their prejudice will not let them see them. This will appear plainly as we go on with our discussion.

But the question now before us is as to what is the next step. As preparatory to this, we need to recur for 
a little to some of the dreams already referred to, and note their impractical nature. For when there is serious division of opinion as to which of several roads to take, much is gained in having it definitely settled as to which of them are impassable, and in setting up the sign, as a guide to all seekers, "No Thoroughfare." For it is undoubtedly true that the larger part of the world's time and thought and money and enthusiasm is wasted in the endeavor to travel along roads that lead to nowhere-in-particular. Let us note, then, a few of the proposed "short-cuts" that are supposed by many to be the nearest way to the "Coming Civilization."

1. Conimunism - the equal division of all existing wealth. The story goes that one of the disciples of this method for the abolition of poverty called one day on Rothschild, and tried to bring this supposed duty home to his conscience. The Baron listened patiently, and then told him he was quite willing, and would begin with him. Whereupon, after figuring for a minute, he handed him out his share, which proved to be a little less than one shilling. There is no commoner mistake on the part of thoughtless people, who do not stop to apply the test of a small sum in arithmetic, than that which supposes that what is called a fair division of the world's goods would make everybody well-off. I suppose that, according to its population, Massachusetts is the richest State in America. But it is estimated that its total wealth, equally divided among all its inhabitants, would give only somewhere about five hundred dollars apiece all round. That figure is rather above than under the fact. It is clear, then, that we cannot all get rich in that way.

And then experience has proved, over and over again, that about the worst average use you can make of money is to give it outright to the man who has not earned it. It is like putting a gun in the hands of a small boy who does not know how to use it. Neither himself nor his neighbors are safe. For a man has not wealth, in the true sense of that word, on account of what he has, but rather on account of what he is.

'Then, though all were started equal to-day, so far as the quantity of possessions was concerned, where would the equality be in a week? The nature, the training, the 
capacity of no one would be changed. The weak would still be weak, the dissipated would remain dissipated, the fool would continue a fool, while the strong, the self-controlled, the capable, would remain as they were before. The natural redistribution that would inevitably follow would rapidly bring back the old condition of affairs. There are thousands who have neither the aptitude for making money, nor for keeping it. While others, as Oliver Wendell Holmes says, if the world were burned up, would get rich in a week by the trade in potash.

If, then, we wish to get ahead towards the "Coming Civilization," we may as well leave that road alone.

2. One of the most fascinating books of recent years is Mr. Henry George's "Progress and Poverty." When I laid it down, after a first reading, I felt as though the "kingdom of heaven" was so near that the only wonder was that humanity had not stumbled into it without knowing. But a little study showed that his fundamental postulate was false. Instead of the rich having grown richer, and the poor poorer, the hard facts are these: More persons are getting rich than ever before, but the percentage of profit that accrues to capital is constantly growing less. This may be overbalanced by an increasing quantity of business; but the fact remains. While, so far as the poor are concerned, not only has the price of labor increased, both in England and America, during the last fifty years, but the purchasing power of a day's wages has increased at the same time. Mr. George's diagnosis of the disease, then, is false, at the very outset. And, not only this, but the panacea he offers is even ludicrously inadequate. He would have the government take possession of all ground-rents for the benefit of the people as a whole. This he claims would abolish poverty. He thinks it would pay all government expenses, and leave a large surplus for public works and improvements of every kind. But here again a little use of the arithmetic is worth a good deal of zealous talk. Taking the census of 1880 as a basis, it is easily found that the entire land-rent of the United States, if equally divided, would amount to about two cents a head per day. That is, it would reduce our present taxes about one-half. So if there were no other objections to MIr. George's plan, its utter inadequacy would be enough. I advise, therefore, 
all eager travelers towards the "Coming Civilization" not to put too much trust in Mr. George's guide-board.*

3. Let us turn next to Count Tolstoi's ideal country. As I survey it from the outside, and see there no science, no philosophy, no literature, no art, no music, no society, in spite of the fact that there is to be no more fighting and. that everybody is to have something to eat, I confess that it looks to me singularly uninteresting. I am obliged to own that, even for the sake of escaping many evils, I do not want to go there. I will even go further and say that, if the world ever gets to be the realization of his dream, I shall be more than ever interested in flying-machines, in the hope that they may furnish means for emigration to some other planet. With the exception of the peace that he hopes for, his picture looks to me singularly like the old world in its condition of original barbarism.

And then, even though this were not true, the fact that from the very beginning the world has been moving in precisely the opposite direction, would seem to be a somewhat discouraging circumstance. Count Tolstoi believes in God. Now, God is either too weak to help himself, - in which case there is not much hope,-or else he does not hold the Count's views; for, as I have said, for so long a time as we know anything about it, under the government of this same God, the whole drift of things has been the other way. I, for one, do not think there is much use in trying to fight against the whole tendency of the universe. So, whatever we may think of Tolstoi the novelist, I cannot regard his road towards the "Coming Civilization" as an open one.

4. Another dream is that of Industrial Co-operation. From the beginning there has been competition; and under competition has been reached whatever gain the world has made. But it is easy to make this battle of competition appear an ugly and anti-social one. And then, at first sight, it looks as though the profit that goes to the capitalist and the middle-man might be saved and turned over directly to labor.

But let us look at it in another way. This ugly fact of battle, of competition, works badly only for producers or dealers in the same line of goods, and it works badly for them

* 13ut, granting all this to be true, still his "Single-tax" idea may be an improvement on our present methods. I have not studied this sufficiently to feel sure of my ground. 
only as producers or realers. When you look at these producers or dealers as consumers - which they also are - it is decidedly for their advantage; while on the other hand, it is wholly for the advantage of everybody else, and so for the rast majority. It is not then so bad as a superficial glance makes it out.

Then again, competition cannot be escaped until the whole world becomes one vast co-operative society. Cooperative establishments would compete with each other; and though they were as wide as a nation, the nations would still compete.

It is also a fact worth study that, so far, all attempts in this direction have shown such weakness, and have so generally failed, as to suggest some inherent defects in the method. And these defects are not far to find. In the tirst place, it requires a very large capital to-day to carry on any large business; and the general rum of wage-workers cannot furnish this capital. In the next place the chances of failure are great, and most workmen camnot afford to take these chances. For, under the wage system, the laborer is at least practically sure of his living, whether the capitalist makes money or loses it. Under the other system he is sure of nothing. And again, in the third place, is another defect which alone is fatal. It requires a special, a rare ability and training, to manage a large business with success. This is apparent in the fact that about ninety-five per cent. of those who attempt to manage any business, whether large or small, fail in the attempt. There are in the country, at any one time, about as many business geniuses as there are military geniuses. What would be the chances of success in war, if generals were to be chosen by popular vote in the arrny, and to be subject to removal whenever the army was not satisfied? So, in the management of great industrial concerns, the leader is found by a process of natural selection, and not by popular vote. 'The chances of being struck by lightning are many more than would be the chances of the fittest man's being chosen by a body of co-operative workmen as the one to manage their affairs for them. Poor judgment, personal bias, envies, jealousies, impatience of delay, — these qualities of average liuman nature must be outgrown before this method can meet with any large success. So, at the entrance of this 
road also, let us set up the sign, "No Thoroughfare"; and look in some more practical direction.

5 . What shall we say of State Socialism or Nationalism? Only that while we can make it look very attractive on paper, we have as yet no experiments in that direction sufficiently successful to promise much of hope. The principle of Socialism is of course conceded. Every time we permit the government to put its hands in our pockets and take therefrom the smallest sum in the way of a tax; every time we submit to a war-necessity and concede the right of the State to compel a citizen into the army for the public good; in these, and in many other ways, we admit the supremacy of the general good over the individual. It is, then, only a question of expediency, to be determined in the light of human experience. The battle between private property and State ownership is only a question as to which, in its practical working, will best subserve the jublic: good.

It is sometimes said the State manages the Post-Office Department, and does it for the whole people, honestly, efficiently, successfully; and the question is asked as to why it might not work as well in all other directions. 'Two answers are ready. First, the Post-Office Department has never paid for itself, but has always been a drain on the public treasury. And, in the second place, the principal part of the postal-service is still in private hands, and is not. the work of the government at all. All the government does is to collect and distribute. All the work of carrying, and the fact that they can be carried so cheaply, is wholly a matter of private enterprise and private competition. So this is no example of what the government might do. I have often been inclined to think it might be well for the government to take control of at least the telegraphs and the railroads. But even here the way does not seem quite clear. Certain European governments do control a part or all of the railroads; but I think I am right in stating that the cost of travel on them is higher than it is with us under. our private ownerships and competitive system,- and if I wish to go to Chicago, it is not a question with me as to. who owns the road, but as to what the owner is going to charge for taking me there. So I cannot help fearing that the ideal Boston is farther off than Mr. Bellamy has dreamerl 
it. It may be well to experiment in this direction; but any steps should be slowly and cautiously taken.

We are impatient, and - in the sense of a high discontent with poor conditions - we ought to be impatient, of the existence of so many social ills and imperfections. During the Middle Ages a great army of children started out on an enthusiastic crusade in search of the Holy Land. At first they thought it very near. And as each common town rose in sight, their hearts beat with eager expectation, and they cried out, "Is this Jerusalem?" And then, wearied and sobered, they would start on again for the city that they still knew was somewhere, though farther off than they had fancied it to be.

Like these children the human race marches on. It believes in the unseen city; but, in spite of many disappointments, it allows itself to be over and over again deluded into the belief that the first town caught sight of by any enthusiast is the city of its hopes.

One fundamental fact cannot be too deeply impressed on all hearts or kept too constantly in mind. 'This fact is that a perfect building cannot be constructed of imperfect bricks. A perfect society cannot be made out of imperfect individuals. Rearrange them as you please, and so long as the materials are defective the defect will appear in the result. Forgetting this is the radical error in all those theories that propose some short cut to the "Coming Civilization," while men and women are left very much the same as they are now.

Having put up our warning signs, "No passing," at the entrances of so many roads, some persons may be inclined to think that I regard all of them as cul de sacs, and that the only thing left is for us to plod on after the old fashion, "content in that station of life in which it has pleased. Providence to place us," as the Prayer Book has it. But no, I hold no opinion of the kind. Nor have I, on the other hand, any pet "City of God" of my own that I expect to see suddenly descending out of a magical sky. If there is any hope at all in the future, it is the hope that shines out of the past. Something, and, I believe, very much, is possible, if only people witl stop merely dreaming, and, in the light of established principles, will go to work.

In the first place, I do not at all believe in the laissezfaire theory, in letting things take their own way. Under 
the working of "natural selection," all life lifted and advanced, until man appeared. But since then, something else has appeared; artificial or human selection has been at work. I am well aware that it is a matter of clefinition, and that, in one sense, what a man does is as natural as is that which is done by a horse or an elephant. But, to avoid confusion of thought, we call that which has in it the element of human purpose artificial, as opposed to that which takes place apart from the control or guidance of the human will. There are many famous scientific men who seem to me curiously illogical here. They seem to have a sort of blind worship for what they call "natural" law, and appear to regard it as a holy ark that the profane intermediller. must not lay his hands upon. And, at the same time, they know, as well as the rest of us clo, that from the day when the first man-like creature tore off the limb of a tree to be used as a club, every step in civilization has been a step artificially created and taken. That is, "human" selection has always been at work modifying the results of "natural" selection. If a man can change the course of a mountain torrent, and prevent its devastating a bit of ground that human selection has turned into a garden, why should he sit passively still and let any natural force override him, provided he has the skill and power to prevent it? At any rate, all the civilization we have has been the result of human interference in modifying the working of natural forces, and so turning them to the accomplishment of liumanly thought-out consequences.

We are familiar with the fact that living forms always tend to become adjusted to their environment. And it is true that the lower life-forms are practically helpless in the hands of the forces and conditions that environ them. A bird will build a better nest if you furnish him a better place and better materials. But while man also tends to become adjusted to his environment, he has the power of thinking out and creating a better enviromment, and so, inclirectly, of lifting his average life to higher levels. To do just this is the work of that luman selection that seeks to create a better civilization.

I believe, then, that Prof. Lester F. Ward is right in the main iclea of his "I)ynamic Sociology." He thinks that man has at last reached the point where he can delib- 
erately plan out and create for himself a higher type of civilization.

Now, what is that ideal condition of the world of which all lovers of their kind must sometimes dream and which they always desire? In broad outline, it can be indicated as a condition of things in which all persons shall be released from over-drudgery, and shall have both leisure and means to develop and gratify the higher wants of their natures. This would necessarily mean, and would carry along with it, the elimination from human society of nearly all its present disease and vice and crime. For most of these are the natural accompaniments of our present imperfect stage of civilization.

In order to do this, more wealth must be created. For we have already seen that an equal division of all that now exists would not be enough for our purpose. To do this would seem to demand a more exacting toil on the part of everybody, instead of setting people free to cultivate themselves into a capacity for living human lives. But this I believe will appear to be a fallacy, and that our hope of sufficient leisure is not an unreasonable one.

In the barbaric ages, men had few wants, and those almost exclusively of an animal kind. And so long as man is compelled to work all or most of his working hours for mere subsistence, he can be only an animal who hunts or fights for his prey, tears and devours it, and then goes to sleep, only to go through the same routine another day. He must develop the mental, the moral, the spiritual, the social, in him, before we can call him civilized. To this end he must have time and means. To this hour in the world's history, it is only in so far as time and means have been gained, and in the case of those who have gained it, that any civilization has been attained.

Here, then, we face the problem. It is along this road, if at all, that mankind must go. Can they go? Is it an open road? Or, if not open now, can we open it? I believe we can. I believe this old earth is capable of sustaining an ideal civilization - one as fair as the fairest that any most enthusiastic dreamer has dreamed. And I believe this wondrous race of ours, that has accomplished so much, is capable of realizing it. But it must be by facing facts, and by working along the lines of existing laws and forces. 
There is no magic about it, no short cut, no royal road. It is not to be learned in "six short and easy lessons."

Those who are already educated and rich and well-off should remember two things. First, no true man can be truly happy while so large a part of the world is unhappy. For our happiness we need to cultivate general happiness. And, in the next place, no house is safe, however wellfurnished, and however gay be the company within, so long as the foundations are insecure. And the foundations of our society to-day are the millions who will not be slaves again, and who cannot go on to a manly and prosperous content without our aid. Preach to them only the doctrine of quiet, and take on the airs of masters, and their answer is dynamite. They cannot go back, they will not stand still; and so we must, if for no higher motive than our own safety, help them to go forward.

What now can we do? I have left myself little space to tell, and I would need a book to detail and argue it all. But since I am only to hint it, I have plenty of time for that. If my suggestions are living seeds, they will germinate after I am done.

The first thing to be done is this: Society at last recognizes its right, and it already has the power, and can use it, to make knowledge compulsory and universal. No boy or girl should be allowed, from this day, to grow up without knowing what kind of a world this is, by what stages humanity has advanced to where it is to-day, and so, by what steps it may be expected to go on to-morrow. Men are victims of their conditions, the tools of knaves and other fools, because they are ignorant. The race has gained a certain accumulated stock of verified knowledge. It is this that sets men free and makes them masters of their circumstances. This accumulated stock of knowledge, then, ought to become the common property of man. This is the first thing.

In the second place, we can do at least a little in the way of destroying the present wide-spread monopolies of the natural resources of the earth, that can never justly be the property of any indiviclual. No man call properly be said to own that which he does not make or produce, such, for example, as land, mines, water-power, coal-beds, etc. But as most of these things are now bound up with additions to, or modifications of, other things that are individual 
property, they present a practical problem most difficult to solve. But, so far as possible, every mall ought to have access to, and use of, all these things, and so unhampered opportunity.

The third will take me a little longer to tell. A man becomes more a man by as much as his permanent wants become more and higher. So long as he wants only food, clothing and shelter, he is but a higher kind of animal. As his higher nature unfolds, and he wants books and music and art, then only does he become, in the higher sense of the word, human. But before he can be developed into really wanting these, he must have, at least, some leisure: for this kind of culture requires time. Children, then, must not be allowed to be put to daily labor, or at any rate, to more than half-day work, until they have been properly schooled and taught. And not only this, men and women, if they are to live, and so maintain, this higher life, must have some time to read and think, to breathe the air of art, and to listen to music. They must have time to mingle with their fellows in what we call society. Is it not these higher things that we mean when we speak of living? Take from us our society, our books, our pictures, our statuary, our music, with all that these imply, and would we care much to keep the rest? If this be so, is not what is necessary to the real human life of ourselves necessary to all? In so far as they are men and women, it most certainly is.

If, now, we are wise believers in Evolution, it has taught us one thing; and that is that the world advances not by leaps, but by the method of growth. So we shall not expect everything, or too much, all at once. If we can take the next step, we shall do well. This next step on the part of the great army of wage-workers, I believe, with Mr. George Gunton, to be shorter hours of daily labor. I incline to think that he has wrought out this problem from the point of view of political economy.

Fewer hours of labor would mean the employment of the unemployed; and so the removing of the burden of their support from the overloaded shoulders of the workers. The more wage-earners there are, the more consumers; so it would cause a widening of the market of the world. With ever more and better machinery, along with the education of the laborer, and so the increase of his skill, there might 
be an immense increase of production, and so increase, insteal of lessening, of wages. With higher education, more leisure, and an elevation of popular taste, there would be ever less and less of the waste and inefficiency caused by vice and crime.

These steps, then, society is competent to take. I see $n o$ other way. It must be by education, and so through increased mastery of the natural forces on the part of man, that the higher life must come. That which lifts the social level, creates in man higher wants, and so stimulates him to the production of ever more and more of those things in which real wealth consists, to the end that these wants may be supplied, - this and this only can help the race on to the next step towards the "Coming Civilization." This is the lesson of all the past, and here is the prophecy of the future. Long and weary has been the way. But if Evolution teaches anything, it is tireless patience and deathless hope. I close, then, with a song I once sung of

\section{THE PEOPLE.}

Oh, placable and patient race, Thy burden bearing through the years !

How often marred with grief thy face, How oft thine eyes are dim with tears !

How patient art thou with thy gods, Still framing for them some excuse, Bending thy back beneath their rods, And turning pain to noble use !

How patient art thou with thy kings, That rob, and fatten on thy spoils ? While each new year new burden brings, To bind thee to thy weary toils.

Be patient still, and labor on !

Thy waiting is not all in vain ;

For, see! long hours of dark are gone, And, east, the night begins to wane.

Science, man's mighty friend, has bound Nature's trained forces, foes no more: They stamp their hoofs, and at the sound Flies open every once-barred door.

And through these doors man shall advance, And find free course o'er all the earth;

No more the slave of circumstance,

But rising to his kingly worth. 
He claims his birthright, now, and reigns:

The Titans that o'er chaos ruled,-

Lightning and steam, - with giant pains,

Now run his errands, trained and schooled.

O People ! once a mass, held down,

The plaything of the priest and king,

You yet shall come into your own,

And to you earth her tribute bring.

Dethroned, the gods of wrong and hate;

Dethroned, the old-time kingly power;

Dethroned, the priesthood's selfish state;

Reason enthroned, then comes your hour!

The spelling-book shall be the key

To thrust back in the lock of fate

The musty bolts of destiny,

And bid you enter now, though late.

But, on God's clial-plate of time,

'Tis never late for him who stands

Self-centred in a trust sublime,

With mastered force and thinking hands.

The world, then, all before you lics :

The stars fight for you; and there waits

A future where bold enterprise

Flings open wide the long-shut gates. 


\section{ABSTRACT OF THE DISCUSSION.}

\section{Mr. Thaddeus B. WAKeman:-}

My first duty is to thank the speaker of the evening for his scholarly and eloquent address. Evolutionists are a unit as to the ideals toward which they would strive. The only difference is as to the methods by which we can take advantage of the possibilities of evolution. Of the many admirable points in the lecture, that emphasizing the importance of the human will in solving the sociological problem seems to me the most significant. Spencer and his school have given us the idea that evolution is a mechanical process, independent of the moulding power of human effort. I agree with the speaker in the main, but was he not a little premature in putting up "No Thoroughfare" on the various roads by which people are striving to remedy the ills of society? Is not his own panacea of the eight-hour law and the education of the laborer also inadequate, equally with Georgeism? I believe the true remedy is to be found to some extent in Nationalism, and also in a modified form of Co-operation. I think the way is to be found in the public administration of business, or State Socialism adapted to this country. Evolution indicates that the co-operative attempts of the people in the way of governmental business, the post-office, the conduct of war, etc., are to be followed by a great Co-operative Commonwealth. Professor Gunton's plan would be at best an application of the feudal system to industry. It leaves the worker in his condition as a hireling, and does not open up for him a career of his own. The accumulation of wealth is a social necessity. The only question is, who shall be the monopolist? Shall we have one monopoly, controlled by Uncle Sam, for the benefit of all his people, or many monopolies, controlled by Jay Gould, the Standard Oil Company, etc., in their own interest? The road indicated by Mr. Bellamy, in "Looking Backward," seems to me to be the right one - the one we might travel.

\section{Mr. JoHN A. TAYLOR:-}

I think we have never heard a clearer or more comprehensive discussion of the various theories of social reform than has been given by the lecturer. Evolution has accomplished everything in 
the world that has been for good. The remedies of the philosophers have almost always failed when they have been applied. The gentleman who last spoke has indicated his belief that the paternal form of government will accomplish the rectification of all social mal-adjustment. But this is contrary to Spencer's wellknown philosophy as to the limitations of governmental interference. It has been said that Herbert Spencer's discovery of the universal law of social evolution was as notable as Newton's discovery of the law of gravitation. Spencer sought to formulate a law of nniversal application, which would make it possible for us to predicate the future tendencies of society. At this last meeting of the Association for the year, it will not be inappropriate to characterize the work of Mr. Spencer very briefly. It was in this country that he first received recognition and substantial support. If he could know how greatly he has helped thinking minds all over this country, by putting into the thought of the world a great principle which shall endure forever, he would perhaps appreciate, to a larger degree even than he does now, the breadth and greatness of his life-work. Spencer is the master-mind of this generation, and our work will fail of its best results if it does not lead us to a more thoughtful study of his works.

\section{Professor George Gunton:-}

I have never heard a lecture which had such a clear and firm grasp on the problems involved in the future evolution of society. I was particularly pleased with the lecturer's assertion that our study of the past is to furnish us with our guide-board for the future. Whenever a "panacea" is presented to us, we should ask whether it is in line with the progress of the past. I agree that "No Thoroughfare" is the proper inscription to write on most of the social guide-boards. I have just finished reading Mr. Bellamy's book, "Looking Backward," and also his article in the Nationalist, telling how he came to write the book. He says at first he had no interest in the subject, beyond the desire to write an interesting book, but as he went on his scheme evolved,-developed out of his inner consciousness, so to speak. This shows the necessarily crude and impractical character of the thought of the book. Mr. Wakeman and I agree that we have to obey evolution. But which way does the evolutionary current set? Always away from paternal government and toward Individualism. If this is true, and it can be doubted by no careful student of history,-we certainly have a right to label Mr. Bellamy's scheme, "No Thorough- 
fare." All improvements in social conditions must come through the direct action of the people, and not be concocted for them. Society cannot be perfect unless you have perfect social units. All experience points in the direction indicated by Mr. Savage - that. of giving the laborer fewer hours of labor, and thus permitting him to work out his own salvation.

\section{Nr. William Potts :-}

I have not read "Looking Backward," I am sorry to say, and therefore cannot attempt to criticise its theory of social reform, except indirectly, and in a very general way. But I have had some experience with the public management and managers of affairs - all I want; and if we are coming to a time when all private affairs are to be managed by public officials, I shall be glad to try my chances in some other planet where affairs are still under private management. In regard to the future, let us speculate as we will, but let us be conservative in action. No permanent change in individual character or social conditions is ever made suddenly or by means of a long step, all at once. The one thing that is perfectly sure in social evolution is that each one of us is to do the best work he can do. We are to reform society by patient, persistent, Christian work and influence, one man acting upon another.

\section{Dr. Robert G. ECches:-}

Mr. Wakeman considers that the human will is the great thing. in social evolution. But does he not know that the buman will is liable to go every way, including the wrong way? While it goes one way, the great evolutionary forces of nature may be going another. The human will was a great force in the Spanish Inquisition - but then it went the wrong way. Constant progress is in part the result of the action of the human will, but that is not the most efficient factor. Again, evolution does not necessarily mean seriality, does not mean constant progress in one direction. Instead of reaching toward unity, evolution makes for diversity. Under State-Socialism the tendency to social advancement would be retarded or altogether checked, for all social and individual advancement depends upon the increase of wealth in the community. There will be a constant tendency to increase wealth and wages where there is encouragement for men to go into business for themselves, because the more employers, the more competition there will be among them for the services of the workingmen. 
Even under our present system, wealth is largely devoted to the general good. No man can do what he will with his wealth.

REV. JoHN W. CHADWICK:-

The following letter was read from $\mathrm{Mr}$. Chadwick, who was absent in Boston at the time of the meeting:

Mr. Erlosworti Warner, Brookly, May 24, 1889.

Secretary Ethical Association:

My Dear. Sir: I am very sorry that your gain in Mr. Savage and his lecture is my eternal loss, as I am obliged to go to Boston and preach for him. This is a miserable Castor Pollux kind of an arrangement, which I trust ministers of religion will not be subjected to when the good times predicted by Edward Henry-GeorgeMost-Pentecost Bellamy have come to pass. I should like to be in Brooklyn to hear Mr. Savage and to say a few words afterward expressive of my satisfaction in the Winter's work of the Ethical Association, and especially of my sense of obligation to Dr. Janes, to whom, I am sure I may say, without disparagement of any, we are more indebted than to any other person for the inception and successful conduct of the course. If the speaking and printing of the lectures marked our complete accomplishment it would still be considerable, but I am bound to believe that they have stimulated many to such reading and study as must be pursued before the doctrine of Evolution can be vitally appropriated. I am also bound to believe that we have done nothing for science which we have not also done for religion, which is the poetry of science and of ethics.

Yours very truly,

JoHN W. CHADWICK.

Letters were also read from members of the Sociological Section of the Natural History Society of Birmingham, England, and James Grosclaude, C. E., of Paris, France, expressing sympathy with the aims and work of the Association.

Mr. SAVAgE replied briefly to his critics, defending the views expressed in his essay. 


$$
\begin{aligned}
& +1,5 \\
& 3 \times 1^{2}
\end{aligned}
$$




\section{N D EX.}

Abliot, Dr. Fraxcis E., on the new teleo?ogy, 339.

Abiogenesis, $125-126$.

Agassiz, Prof. Louis, 29; his Essay on Classification, 36; his opposition to Darwinism, $40,42,173$; his laws of evolution, 141.

Acnosticism, Herbert Siencer's relation $t(1,16$; religious attitude of, 22 ; of science, 107,133 ; complere with meta-cmosticism, 226 ; iu theological evolution, 249, 250; compared witl materialisim, 350; the synthesis of materialism anıl spiritualism, 365.

Allen, Prof. Jerome, on Christianity and evolution, $338,339$.

Altruism and egoism, their relation to conduct, 215, 264-268, 272 .

Anaplotherium - a link in animal evolution, 305.

Anarehy, as a theory of social reform, 372 .

Animals and Plants under Domestication, 31.

Animism, 238.

Anthropomorphism, its place in theological evolntion, 245, 251.

Appleton, D. \& Company, 7,18 note, 20, 55 note.

Aquinas, Thomias, 281.

Arcalia, Sidney"s, 369.

Aristotle, Herbert Spencer compared witl, 3; on organic remains in the rocks, $91,236,281$; would not have regarded evontion as a philosophy, 358.

Arnold, Matthew, 10 ; his depreciation of material progress, 358 .

Artificial breeding, $148,153,306$.

Artificial selection, Darwin's work on, 31 : in vegetal evolution, 128-130 ; in animal evolution, $148-151,153,15$ ); in cotton-culture, 171 ; as a proof of evolution, 306 ; in social evolution, 382.

Aryan nythology, in theological evolution, 240.

Assyrian pantheon, 241

Astronomy, as related to evolution, $55-74,345$.

Atheism and evolution, 43, 227-228, 250 .

Australian fama, illustrative of evolution, 301.

BABYLONIAX RELIGIOx, in theological evolution, 241.

Bain, Alexander, on mental evolution, 192; lis definition of will, 276 .

Baring-frould, S., on the origin of monotheism, $243,244$.

l'athvbius, 119,185 .

Bellamy, Edward, his views criticised, $371-372,380-381$.

Bellows, Heury S., on social evolution, 229.

Bible, the, and evolution, $79-80,91,104-107,143-145,205,209,223-224,225-227$, $321-3 \%$.

Binet, Alfred, on micro-organisms, 18t-185, 198 note.

Biology, Darwin's works on, $31-39$; as related to geology, $97-101$; in vegetal evolut:on, 111-136; in animal evolution, 145-157; in human evolution, $161-17$; ; as lelated to psychosis, $184-187$; as related to social evolution, $205-212,216-223,228$; as related to moral evolution, $259-262,266$, 268; its proofs of evolution, $289-316$.

Blanchard, Dudley, on mechanical erolution, 365.

Botany, as related to evolution, $111-136,345$.

Boughton, William H., on Charles Darwin, 49.

Bram, Ur. Karl, on planetary evolution, 62.

Bruno, fiordano, on pre-existence, 275.

Buffon, on animal classification, 36.

Burton, Capt. O. F., on human evolution, 175; on the L'nknowable, 199.

CATAGENESIS, 186.

Chadwick, Rev. John W., on Herbert Epencer, 21; on Charles Darwin, 25-46; on theological evolution, 25:2; in reply to 1 'rof. Davidson, : 82 ; on Evolution and Religion, 319-33\%; on the work of the Ethical Association, 391.

Christianity and Evolution, 205, 215. 2223, 22t-627, 338-340.

Chambers, Robert, on use as affecting structural changes, 142.

Coakley, Prof. George W., his illustrations of Laplace's hypothesis, 55 note, 56 , $57,58$.

Coan, Dr. T. Munson, on human and regetal evolution, 171. 
Communism, as a social icleal, $376-3 \%$.

Comte, Auguste, his relation to the plilosophy of evolution, $343,349-350$.

Consciousness, as a factor in evolution, 152, 166-169, 184-194, 197-198; its testimony as to physical and mental phenomena, 350-354, 365-366; dependent on a brain and ne'ves, 352.

Contract society, 214.

Co-operation, inclustrial, as a social icleal, 279, 378-380, 388.

Cope, Prof. Edward D., on the evolution of the horse, 100; his "Neo-Iamarchism," 155; on the descent of man, 161-170, 175; on catagenesis, 186; on t.13 will as a factor in evolution, 192.

Copernican astronomy, as related to theology, 321.

Coral polyps, in geological evolution, y2.

Coral reefs, Structure and Distrilution of, 29.

Creation, the Bible accomnt as compared with evolution, 46, 70, 79-80, 91, 143, 169, $205,209,223,32 t-329$.

Cross and Self-Fertilization of Plants, 31.

Darwin, Charles Robert, his relation to the evolution philosophy, 12, 13, 22, 343 ; his life and work, $25-46$; poem on Darwin, 47 ; his mental greatuess, 49 ; recognition of his work in Holland, 50 ; on climbing plants, 121 ; on natural selection, 128, 264, 289 ; on orchids, 129 , 130 ; on pangenesis, 129 ; on fertilization of clover, 131; imperfections of his theory, 141, 142, 150, 151, 153, 164; his letter on animal remains in S. A., 157; on descent of man, 16t; on belief in God, 234 note; on primitive man, 261, 262; on origin of morals, 263 ; on human evolution, 295 ; theological implications of his doctrine, $322-330$; his idea of creation, in Origin of Species, 324-329; on the origin of life, 323 329 ; compared with Hegel, 346-348; as related to the philosophy of evolution, $343-348$; not a stuclent of the mind, 303.

Darwin, Dr. Erasmus, 25, 27, 32.

Darwin, Robert Waring, 26.

Data of Ethics, 13, 195, 259, 269, 270, 274.

Davidson, Prof. Thomas, on human evolution, 173; on anoetic knowledge, 183; on the evolutionary theory of morals, 281 ; his metaphysics, 331.

Dawson, Prof. William, on the enzoon canadense, 101.

Descartes, as related to the evolution philosophy, 343,346 .

Descent of Man, 31, 34, 40, 41; lecture by Prof. E. I. Cope, 161-170, 175: Dr. T. Munson Coan on, 171; Dr. Henry S. Drayton on, 172; Prof. Thomas Davidson on, 173; Dr. Robert G. Eccles 0n, 173; as related to morals, 261, 263, 302.

Descriptive Sociology, 7 note.

Design, doctrine of, as affected by evolution, 143.

Development Hypothesis, $5,12,33$.

Discovered links, 302.

Divine ag'ency in evo'ution, 45, 46, 103, 133, 134. 143, 154, 156, 205, 280.

Doornik, Dr. J. E., on evolution, 50.

Drayton, Dr. Henry S., on human evolution, 172.

Duration of geological periods, 101.

Dutch scholars on Darwinism, 50 .

Dyer, Prof. W. T. Thistleton, on distinctions between plants and animals, 122. Dynamic Sociology, 382.

EARTHQUAKEs, 93, 94.

Earthworms and Vegetable Mould, 29, 31.

Eccles, Dr. Robert G., on the nebular hypothesis, 71 ; on vegetal evolution, 136 ; on animal evolution, 155; on human evolution, 173; on the evolution of the mind, 179-196, 199; on the will as a factor in evolution, $276 ;$ on the definition of life, 283 ; on proofs of evolution, 315 ; on the philosophy of evolution, $364-365$; on social conditions, 390.

Education, Spencer's work on, 15 ; need of compulsory, 384.

Effects of Evolution on the Coming Civilization, 369-330.

Ervptian mythology, 242.

Enibryology, as affecting evolution, 38, 147, 164, 296-298, 311.

Emerson, Ralph Waldo, his advocacy of evolntion, 32; his definition of virtue, 257 ; remark on compunctions, 275 ; on the thinker, 287 ; his intuitional pliilosophy criticised, 349 .

Enviromment as affecting development, 146, 156, 165, 171, 266, 275, 283, 289-290, $300-302,316$.

Eozonn Canarlense, 101.

Essay on Classitication, 36.

Ethical aspects of Evolution, Mr. Spencer's view, 13-14, 21, 22; Darwin's view, 41; Prof. Cope on, 169; Ir. Coan on, 171; as relaterl to niental evolution. 194-196; as relateci to social evolution, $224-225$; in theological evolution, 244 
246 ; in Judaism, 245, 246, 252, 253; Dr. L. F. Janes on, 257-280; as compaled with netaphysical systems, 268-280, 281-284; M1. N. C. P'arshall on, 312-313; Rev. J. W. Chadwick on, 319-320.

Evolution, Herbert spencer's relation to, 3-22; Charles Darwin's relation to, $25-51$; solar and planetary, 55-75; of the earth, $79-107$; of vegetal life, 111 136; of animal live, 132-15\%; or man, 161-175; of the uind, 179-200; of socicty, 203-230 ; of theology, 233-253, of morals, 257-284; of indlustries, 374-375; proofs of, 287-316; as related to religinus thouglnt, 319-340; philosoluly of, $343-366$; effects of on the coming civilization, 36 ')-390.

FA rE's HYPOTHEsIS of planetary evolution, 61-62.

Fertilization, of plants, 31, 123-125; of orchids, 31; of tho rose, 112; of apples, 116. Fetishism, in theological evolution, $240,251$.

Fiske, Prof. John, on Agassiz's Essay on Classification, 36 ; on mental evolution (reference), 181$), 182,188,195$; on human infancy as affecting moral evolution, 262; his definition of will, 276 ; on evolution and theology, 333 : on the value of moral beliefs, 337 ; on the relations of mind and matter, 350 .

Foramenifera, 50 .

Force, an ultimate element in the material world, 351 ; not what it appcars to be, 365 .

Formation of igneous rocks, 93 .

Formation of organic roclis, 88.

Formation of stratified rocks, st.

Forms of Flowers, 31.

Four great factors of erolution, $28 ?$.

Freedom and necessity, 276, et ser.

GArdxer, Thomas, on Herbert Sipencer, 22 ; on moral evolution, 282:

Gates, Nelson J., on mental evolution, 198; on moral evolution, 282; on proofs of evolution, 315 .

Geikie, Dr., on Darwin, 29,30 ; on the age of the earth, 122.

Geographical distribution, 300-302, 312.

Geological evolution, 79-107.

(reological succession, of animals, 97 ; of plants, 126-128.

Geology, as relaterl to evolution, $296,311,34 ;$.

George, Henty, his social philosoplly, $37 \overline{7}-378$.

Glacial action, 82.

Gnosticisul, in thenlogical evolution, 244.

Goethe, his advocacy of evolution, 32 ; his mental world, 18.5 ; on mind and matter, $19 \pi$; his pantheism, 251.

Golden Rule, as compared rith the ethics of evolution, 273 .

Gottheil, Rev. Dr. Gustar, on the Hebrew monotheism, $25 \%$.

Gravitation, as related to cosmic evolution, 55-60, 73-7.4; its cause unknown, 72-73; as related to theological ideas, 321 ; its relation to language, 3 (it.

Gray, Prof. Asa, on wild roses, 115.

rreek pantheon, in theological evolution, 241.

Grosclaude, James, C. E., recognition of his letter to the Ethical Association, 321.

Gunton, Prof. George, his eight-hour theory, 285; on social evolution, 389-390; his theory criticised, 388 .

Guyot, Arnoli, on the evolution of the earth, 67 .

HAECKEL, PROF. ERxEst, Darwin's confession to him, 40, 42 ; his description of Darwill, 44 ; on certain forms of alpat, 12, : his mechanical theory of the Universe, 133,329 ; his theory of the descent of 1121,172 ; on life and organization, 185; on embryology, 297; on spontaneous generation, 310 ; his telen!ogr, 329 .

Hamilton, Sir William, his Philosophy of the Unconditioned, 331, 340; as related to the evolution philosopliy, 343.

Hanson, William, on altruism, 230.

Harrison, Frederic, his controver:y with Herbert Spencer, 9 ; his idea of religion, 334

Hawaian islanders, effect of civilization on, 271 .

Hawley, Frederick B., on evolution of theology, 251.

Hebrew monotheisin, as related to theological evolution, 244-24i; to Positivism, 251 ; to theisin ancl ethies, $245,246,252,253$.

Hegel, his plilnsoplhy compared with Darwin's, 346-348.

Helinholtz, on the correlation of forces, 363.

Henslow, Prof., Darwin's description of, 27.

Heredity, as affecting evolution, 147, 150, 151, 154, 283, 290. 
Herschel, Sir John, his theory of the luminous sun-spots, 65 ; of the form of the universe, $67-68$.

Hollhrook, Dr. Martin L., on vegetal evolution, 135.

I Iomologr, in animal evolution, 2y1-2:2)2.

Hooker, Ir., on Herbert Spencer, 9; his relation to Darwin's Origin of Species, 30.

Horse, the evolution of, 38, 98-100, 292.

Humboldt, William von, his political philosophy compared with Herhert Spencer's, 1 .

Hume, David, $3+3$.

Huxley, Prof. Thomas H., his defence of Darwin, 40 ; on the inflnence of the Origin of Species, 42; on Darwin's honesty, 44-45; on the proof of biological evolution, 100; on organic and inorganic sulstance, 118; om micro-organisms, 119 ; on bathybius, 119; evolution no longer an hypothesis, 304 ; on mind and matter, 350 , 366.

IGXEOUs Rocks, the formation ofi, 93.

Inmortality, evolution's word comcerning, 33t-336, 338.

inclustrial evolution, $374-375$.

Infertility of species, $149,151-153,155$.

Intuitional philosophy, 349 .

Island life, illustrative of evolution, 98, 156, 301-302.

Janes, Prof. Williair, on mental evolution, 185.

Janes, Dr. Lewis G., on the philosophical aspects of cosmic evolution, it; on the evolution of the earth, $79-103$; on the laws of organic and inorganic growth, 136 ; on the law of population, 172 ; on mental evolution, 197; on Spencer's theory of government, 230 ; on the personality of the Absolute, 253 ; on the evolution of morals, $257-280,283-284,319-336$; on Spencer's "Unknowable," $339-340$; on the philosopliy of evolution, 365.

Japan, evolution in, 50 .

Juclaism, as related to evolution, 244-245, 252; as related to Christianity, 246, $339-340$.

Kant, Exanuel, his conception of the ding an sich, 182; on the moral law, 265 ; on good and evil, 273 ; on the will, 277 ; the evolution-pluilosoplyy not derived from him, 343 ; his Critique of l'ure Reason, $343,346$.

Kennan, George, his testimony as to Spencer's writings in Siberia, 6.

Krakatoa, the volcano of, 94 .

LAMARCK, anticipated by Dr. Erasmus Darwin, 26; his advocacy of evolution, 32 ; his theory of use as affecting development, 149-150, 155; inuortance of his hypothesis, 164 ; its correctness, 165 ; its revival by Prof. Cope, 174; a forerunner of the evolution philosopliy, 343 .

Language, its brain-convolution found in anthropoid apes, 162 ; evidences that primitive man was deficient in speech, 164; its evolution, 262, 264, 363; it differentiates man from the lower animals, 262, 312; the connecting link between mind and nuatter, 363-36t.

Laplace, his theory of solar and planetary evolution, 56-60; rejected in part by Faye, 62 ; the theory not wholly satisfactory, 71 ; oljections to it, 73 ; a forerunner of evolution, 343 .

Law of couduct, as formulated by the evolution philosophy, 272 .

Laws, matural and divine, 133.

Laws of evolution, $1+1$, et ser.

Le Conte, Prof. Joseph, on the subsidence of the earth's crust, 93 ; on geological evolution $95-96$; on the effect of astronomical and geological studies, 102-103; on spontaneous generation, 140 ; his definition of evolution, 141 ; his formulation of its laws; 141 ; his judgment of Romanes' theory, 151 ; on the influence of natural and sexual se!cetion, 290; on artificial and natural selection, 306 ; on spirit immortality, 336 .

Leiloniz, his doctrine of pre-existence, 275 .

Lewes, George Henry, on the spinal cord as a seat of consciousness, 193; on the interdependence of organic and mental forces, 363.

Linnaens, Darwin's acquaintance with his cystem, 26 ; his hasis of classitication, 36 .

Locke, Jolm, $3+3$.

Looking Backward, 371-372, 388.

Lotze, frerman, his doctrine of pre-existence, 275.

Loves of the Plants, 26.

Lubbock, Sir John, on the intelligence of the ant, 172; on ancestor-worship, 225.

Lyell, Sir Charles, compared with Darwin, 29); his (loctrine of eontinuity, 30; his relation to the Origin of Species, 30 ; his endorsement of Darwin, 40 ; 
on the gradual character of geological changes, 95 ; on the age of Niagara Falls, 101; his theories as related to the philosophy of evolution, 345 .

MAIXE, SIR HENRY, on ancient society, 214.

Malthus, his theory of population reviewed by Herbert Spencer, 21 ; as related to Darwin's work, 21.

Man, his origin and dlescent, $40-42,161-175$; his age upon the earth, 163; his mental evolution, $179-200$; his associated lite, 203-230; his theological clevelopment, 233-253; his moral development, 257-284; his physical imperfections as related to evolution, 17t-165 299-300.

Mansel, Dean, his doctrine of the Absolute, 249 ; his philosophy as compared with that of Herbert Spencer, 250 note, 331,340 .

Marriage, as related to social evolution, 210-214; as related to moral evolution, 263-265; its earliest form, 264 note; its order of clevelopment, 374.

Marsh, Yrof. Othniel C., on fossil remains, 98; on the evolution of the hor c, $98-100$; his discoveries of fossil birds, 305.

Marsujia!s, their place in the order of animal evolution, 161, 304.

Martineau, ILarriet, 331.

Hateriali=m, as related to the evolution philosophy, 169, 350-35t; compared with spiritualism, 354-366.

Iiatter and spirit, what we know of them, 133,169 ; their indestructibility, 180182 ; their relation to the Unknowable, $133-181$, 350-353; their relation to consciousness, 365 .

Maudsley, Dr., on the seat of sensation in the brain, 193; his materialism, 366.

llechanical inventions and civilization, $356-35 \%$, 365 .

Mental evolution in Man, 234 note.

Irerwin, Prof. Almon G., on mental evolution, 198.

Meta-gnosticism, 225-22\%.

Metanorphosis, proofs of evolution from, 298.

Ietaphysics, as related to science, 197, 199); as applied to theology, 248-250; the metaphysical theory of morals, $258-259,273-276$; as bearing upon the philosophy of evolution, $344-349$.

Meyer, on correlation of forces, 363.

Mill, John Stuart, his definition of Matter, 197; his distrust of metaphysics, 281.

Miller, Hugh, his attempt to reconcile the Bible and geology, 104.

Iimicry, proofs of evolution from, 308 .

Mind, as related to life, 134; its correlation with material conditions, 169, 173, 174,182 ; its evolution, $179-200$; is it a function of matter ? 350-354.

Missing links, 101, 149, 291, 302 .

Monism in philosophy, $75,247,365$.

Montgomery, George Edgar, his poem on Darwin, 47 .

Morals, Evolution of, $25 \pi-284,37 t$.

Moral science, the nature of, 268 , ct seq.

Moral sense, the, 312 .

Morehouse, Rev. D. W., on Christianity and evolution, 339.

Morphology, pronfs of evolution 1 rom, $2 \% 6$.

Morris, William, his socialistic ideas, 371.

Iosaic account of creation, $79-80,104,10 \%$.

Muller, Johannes, his adhesion to Darwinism, 42.

Inuler, Max, his doctrine of a primitive monotheism, 24.

Iythology, in theological evolution, 240,

TeBULAR HYPothesis, 55.

Newton, Sir Isaac, his discovery of gravitation, $321,345$.

Nichols, Starr Hoyt, on the philosophy of evolution, $343-361,366$.

OBLIGATIOx, the sense of, in evolutionary inorals, 258, 265, 267, 272-278.

Order of geological succession, 97 .

Organic and inorganic life, 118-121, 130.

Organic rocks, the formation of, 88-83.

Origin of duty, 26\%.

Origin of Species, when published, 12,29 ; when commenced, 22 ; its orderly symmetry, 27; an epoch-making book, 31 ; its theor explained, 32-39, 128131 ; its effect, 40 ; imperfections in its theory, 151 , 16t; the views of critics, 302. Origin of the Fittest, 100 motc.

Origin of variations, 165-166.

Over-lecrislation, Spencer's opinion of, $5,14-15$.

Owen, Prof., on the Australian mammalia, 304.

PAxaexesis, Darwin's theory of, 129-131.

Pantheism, in theological evolution, $247-250$. 
I'arshall, Nelson C., on proofs of evolution, 287-314.

Perrin, Raymond S., his criticisin of Mr. Spencer, 353; on the philosophy of evolution, $362-364$.

P'hilosophy of evolution, 343-366; a vital, not a mechanical philosopliy, 362.

Plato, conipared with Spencer, 3 ; on oreranic remains in rocks, 91; his plilosophy recent, 236 ; had no glimpse of evolution, 343; his idlealism, 356 ; his ideal republic, $358,369$.

Pliny, on organic remains in rocks, 91.

Population, the theory of, Spencer's essay on, 5, 20; Malthus on, 21; I). Raymond on, 148; the law lorietly explained, 172-173; further discussion of the theory, 208-212; as related to morals, 260-261, 26;3-26t.

Positivisin, as related to cosmic sjeculations, $74-75$; its place in theological evolution, 250-251.

I'ott;, William, on the evolution of vegetal life, 111-13t; on theories of social refortil, 390.

Powell, Major, on human evolution and natural selection, criticised by I'rof. Cope, 170 .

Present condition of the earth's interior, 83.

Primitive condition of the earth's surtace, 80 .

Principles of Psychology, the lasis of Spencer's philosophy, 5; publishen before the Origin of Species, 12; it ; loctrine of the Unknowable, 181; it: cloctrine of sense-perception, 188,189 ; the parallelism of mental and physical processes, 190 ; the 1usychology of ethics, 195,266 ; the knowalnleness of mind, 199.

Principles of Sociology, the preparation for it, 203-204; (lifticulty in the sul)ject, 20t; society an oryanisn, 217, 222; social evolution, 228; it; bearings on theological evolution, $23 \pi-2+0$.

Proctor, licluard A., his conception of the form of the universe, 68 ; his theory of cosmic evolution, 72 .

Progress and Poverty, 37\%.

Proofs of Evolution, 287-316 : from geology, 290 ; from morpho'.ogy, 291 ; from embryology, 296 ; from metanor'pliosis, 2298; tron rudimentary organs, 298; from geographical distrilntion, 300 ; from cliscovered links, 302; 1 rom artificial breeding, 306 ; from reversiom, 307 ; from mimicry, 309 ; from the fact of contimuity, $315-316$; in sociology, 316 ; their axionatic character, 315 .

Prophetic types, 146 .

Psychic Life of Micro-organisms, 18t, 198 note.

Psychology (see "Princij)les of Psychology").

Pytlagoras, on organic remains in rocks, 91.

RAYMOXD, DR. Rossiter W., on the evolution of animal life, 139-154.

Reece, Benjanin, on sociological eviclences of evolution, 316.

Religion and science, Sipencer's discussion of their relationship, 17; Rev. J. W. Chadwick on, 42, $43,45-46,319-337$; Dr. L. (A. Janes on, 79-80; William Pott. on, 132-134; I)r. R. W. Raymond on, 142-145, 146, 154; Dr. R. F. Eccles on, 156; Janles A. Skitton on, 205, 207, 223-227; Nelson C. Parsliall oll, 287-289, 313-314; Starr 11. Nichols on, 314-349; Rev. Minot J. Savage o1, 370.

Religion of humanity, 251-253.

Religion of l'hilosophy, 353 .

Reversion, proots of evolution from, 307 .

Rhizoporl, character of, 304 .

Rillenour, P'rofessor William B., on vegetal evolution, 135.

Rig- V'edla, 242.

Romanes, Ur. George J., on Darwin's work and character, 13 ; lis contrilution to 1)arwinisn!, 151-152; on the "post-I arwinians," 16t; defects in his theory of mental evontion, 185 ; on the origin of religious icleas, 234 note: on the jsychic difference between men and lurutes, 235 note.

Roman pantheon, in theological evolution, 241.

Rosmini-Serbati, on pre-existence, 275.

Rudimentary oryans, $37-38,298$.

Pustin, Jolin, his views on government, 22.

SAMPSON, Z. SIDNEY, on social evolution, 228 ; on theological evointion, 233-250.

Savage, Rev. Minot J., on the change of front of the universe, 258 ; on evolution and the coming civilization, 36 ; -386 ; his joem on "The Peolve," 386-387.

Scandinavian inythology, in theologieal evolution, 242.

Schurmann, Professor, in criticism of Kant's ethies, 27.

Seneca, on fossils folmi in rocks, 91.

Sensation and memory, as factors of consciousuess, 166-169).

Serviss, Garrett $l^{\prime}$., on solar and planetary evolution, 55-70, 330. 
Sexual selection, Darwin's hypothesis of, $31-41$; its place in evolution, 148, '28!) ; how it operates, 290 ; in inimicry, $308-30 \%$.

Skilton, James A., on Herbert Spencer, 19-21; on vegetal evolution, 135 ; on evolution of society, 203-2:-

Social Statics, when published, 5: Mr. Spencer's dissatisfaction witl it, 5, 20, 229 ; principle set forth in it, 230 .

Socialism, 380 .

Societary evolution, 203-230.

Society an organism, 21\%, 278, and note.

Sociological Section of Birmingliam, Eng., Nat. Hist. Society, letter from, r('cognized, 391.

Sociology, Principles of (see "Principles of Sociology").

Solar anil planetary evolution, 55-75.

Special senses, evolution of, 186 .

Spencer Herbert, his life and works, 3-22; letter from, 19; the most notable advocate of evolution before Darwin, 32 ; his early essay on development, 33 ; his reception of Darwin's Origin of Sipecies, 40 ; his sociological tables, 139 ; his contribution to the theory of evolution, 142 ; relation of his philosophy? to the doctrine of the correlation of forces, 180 ; his psychology, $181,186,187$, 188, 189, 190, 199; doctrine of the Unknowable, 181, 249, 250 note, 251, 331-334, 350-353, 36t-365; his criticism of Romanes, 185; his ethics, 195, 259-261, 266, $268-280$; his sociology $203,204,217-223,228,229,230$; on the temporary nature of government, 230 ; on ancestor-worship, $235,237-239$; on mytlmaking, 240 ; his definition of life, 266 note; ondesign, 312 ; his religious views criticised, $329-334$; lis philosoplny, $348,350,353$; his doctrine of the interdependency of mind and matter, 363 .

Spencer, Rev. Thomas, 4.

Spiritualism and materialism compared, $354-365$.

Spontaneous generation, $125-126,140,19 y, 309-310,315$.

State socialism, judgerl by evolution, $380-381$.

Stevens, Prof. WV. Le Conte, on geological evolution, 104-10\%.

Stratified rocks, formation of, $8 \%$.

Study of Sociolngy, 194, 203, 229 .

Sympathetic origin of altruistic feeling, 194-195, $26 \%$.

TAYLOR, JoH: A., on the evolution of society, 22!); (nn the effects of evolution on civilization, $388-38 \%$.

Tennyson, Alfred, his gloritication of war, 360 .

Teutonic mythologies, in theological evolution, 242.

Theism, as related to evolution, $16-17,22,46,103,107,133-134,143,154,156-157$, $216,228,233-253$.

Theology, Evolution of, 233-253.

Theory of population, $5,20,21,148,172-173,208-212,260-261,263-264$.

Thompson, Daniel Greenleaf, on Herbert spencer, 3-18.

Thomson, Sir William, his theory of the neteoric origin of life, 169.

Tolstoi, Count Lyof $\mathbf{N}$., his social ideal, 370-371, 373, 37.

Transcendentalism, as related to evolution, $32 \tau, 3 \pm 6-347$.

Treviranus, an early advocate of evolution, 32.

Tyndall, Prof. John, his intimacy with Herhert Spencer, 8; on matter and life, 310.

UNKxoWABLE, Spencer's doctrine of, 16-17, 22; the doctrine criticised, 49-50, 199, 227, 350-353; the principle, as stated 1,y William Potts, 133; ly I)r. Eccles, $181-182,390$; ly Z. S. Sampson, 249-i250; as related to religion and science, 331-334; to philosophy, 350-353, 36t; the philosophical basis of monism, 365 .

Uniformity, the doctrine of, $95,34 t-3+6$.

Utopia, More's, 369.

YAN DER BROEK, PROF. 'T. H., his advocacy of evolution in Holland, 51 .

Van der Weyde, Dr. P. H., on Darwin, 50-51; on the nebular hypothesis, 73 ; 011 Darwin's letter, 157; on physics and metaphysics, '283.

Variations, artificial, 33; as stated ly Darwin, 35 ; in 1)lant-life, $115-118$; in animal life, 147-148, 151-15t; origin of, 16t-166.

Vedas, 242.

Vegetable mould, the formation of, 29.

Vegetal life, evolution of, 111-136.

Virchow, Prof., his opposition to Darwinisu, 173.

Vestiges of Creation, 32,51 ,

Vogt, Prof. Carl, on vegetal evolution, 131; on missing links, 305.

Volcanic Islands. 29. 
Volcanoes, their action in geological evolution, :3:-94 ; phenomena at Krakatoa, 94.

Voltaire, on organic renlains in rocks, 91.

Von Hartmann, Prof. Edouard, on hiunan evolution, 172.

Voyage of the Beagle, 28.

Walie, C. Staxiland, on evolution of morality, 264.

Wakeman, Thadcleus 13., on theological evolution, 251; on social evolution, 388 .

Wallace, Alfred Russel, his relations with Darwin and discovery of natural selection, 30-31; his difference from Darwin, 34; on island-life, 301-302 (compare 1. 156).

Ward, l'rof. Lester F., his Dynamic Sociology, 382-383.

Wedgwood, Josiah, 27.

Weismann's theory of descent, 166.

Wiknn, Prof., on the universality of evolution, 306; on clegeneration, 308

Wood, Rev. J. G., on tlint in vegetal structures, 121 .

Wright, Rev. Merle St. Croix, on evolution and religion, 338.

Youmans, Prof. EDWARD L., on Herbert Spencer's edncation, 4; his inHuence in introducing Spencer in America, 7 ; on the spencer fund, 7 nous; his intimacy with Spencer in America, 9; his death, 12; his articles on Spencer in the P'opular Science Monthly, 18 note; his remarks on Spencer's attempted reconciliation of science and religion, 332 .

Youmans, Miss Eliza A., her jucigment of Spencer's psychology, 7 ; Mr. Tlompsom's indebtedness to her, 18 note.

Youmans, Dr. William J., 19. 
(Twelve postpail for $\$ 1.00$.)

\section{The Modern Science Essayist Popular Evolution Essays and Lectures.}

One of the most systematic, concise and comprehensive presentations in popular form of the foundation and theory of evolution. Excellent, . . . succint, . . . interesting.-Public Opinion.

Papers that are neither dull nor conmonplace.-Boston Times.

The subjects are very fully discussed, and the seeker for information can scarcely find the case better stated.- New Bedford Mercury.

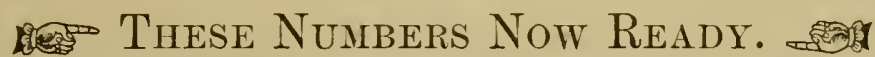

[Nos. 1 to 15 inclusive are comprised in the present volume. Any of the 15 may be had singly, in pamphlet form, for $10 \mathrm{c}$ each; the 15 in one volume, fine cloth, with complete index, $\$ 2.00$; in paper, $\$ 1.50$. For synopsis of each lecture, see "Contents," front of this book. Synopsis of subsequent numbers follows:]

16. The Scope and Principles of the Evolution Philosophy. Wallace on Darwinism; evolution a universal method; agnosticism - what is it ? the nature and limitations of knowledge; the relations of the evolution philosophy to materialism and idealism; to the doctrines and methods of the christian church; its relations to sociology; its attitude toward the practical problems of social life.

By Dr. Lewis G. JANes, author of "A Study of Primitive Christianity," "Evolution of the Earth," etc.

17. The Moral and Religions Aspects of Herbert Spencer's Philosophy. Spencer's Theory of Religion; Spencer's Theory of Morality; the Relation of Religion to Morality from the Spencerian point of view.

By SYlvaN Drex.

18. The Relativity of Knowledge. The nature of sense-perception; sight, sound, taste, smell, feeling; the doctrine of the Unknowable; the relative nature of matter, motion, form, weight, extension; the relativity of ethical and social theories; the truth of definite relations; the doctrine of relativity assures charity and mental freedom.

By Robert G. EcCLEs, M.D., author of "Evolution of Mind."

19. A Study of Matter and Motion. An excellent digest of a much vexed question, with quotations from many authorities,-Prof. Youmans, Herbert Spencer, Geo. Henry Lewes, Prof. Helmholtz, Prof. Coues, etc., etc.

By HoN. A. N. ADAis.

We must not allow any prejudice of thought on account of the cry of " materialism." - Text. p. 6.

20. Primitive Man. Man as revealed by archrological studies; evidences of man's antiquity; geological periods; man's appearance in the pliocene; palæolithic and neolithic races; the ages of bronze and iron; cavemen and lake-dwellers; dolmen - and mound-builders; primitive implements and tools; proofs of man's natural evolution.

By Z. SIDNEY SAmpson, author of "Evolution of Theology."

21. Growth of the Marriage Relution. Marriage a primitive institution; its earlier forms; no eviclence of original promiscuity; exogamy and endogamy; group-marriage; polygyuy, polyandry and monogamy; marriage by capture ; monogany the highest form of the relation; divorce and divorce-laws; inarriage a contract; its regulation by the State.

By C. STANILANi WAKE, author of ""The development of Marriage and Kinship," "The Evolution of Morality," etc. 


\section{Modern Science Essayist-.-Catalogue Continued.}

The lecturers in this collection present the theory of evolution instructively and attractively.-Boston Globe.

A glance will sufficiently indicate the admirable skill and thought that have been bronght to hear upon these suhjects.-Boston Saturday Eveniug Grazette.

There is nothing weak or commonplace in these discussions.-Charlestom (S. C.) Neu's.

All these papers are full of thought, presented in clear language, and in an admiralle spirit.-Religio-Philosophical Journal.

22. Holution of the Stute. The growth of political institutions; the patriarchal family; the tribe and clan; the ancient city; monarchical and representative governments ; constitutions - written and unwitten ; the American Republic-its success and its dangers; evils of municipal government; what final form will the State assume?

By JOHN A. TAYLOL.

23. Hoolution of Law. How law begins; statute law and judge-made law; the conversion of customs into law; religions sanctions; legal fictions; the development of equity jurisprudence; the common law; legislation; the colification of laws; laws for tle collection of delsts; personal rights under the law.

By Prof. Rufus Sileidon.

24. Hinolution of Mediral Srienre. Supernatural ideas of disease; fetishism in medicine; the heginnings of medical science; Pythagoras and Hippocrates, Celsus and fialen; Christianity and medical science; the Mohammeand influence; lomenpathy and allopathy ; fonds and poisons; the rlevelopment of surgery, anatomy, physiology, chemistry and pharmacy; bacteriology; the growth of sanitary science.

By RonT. (†. ECCLEs, M.I)., anthor of "The Evolution of Mind," "The Relativity of Knowledge," etr:

25. Evolution of Arms and Armor. The necessity for arms and armor under the struggle for existence; Nature's two methods - among animals, plants, men, nations; how arms and armor have led to the industrial arts; to a higher manhood; to co-operative effort; to individualism; the weapons of thought; our National policy as regards defenses; the two methods in religion, morals, law, social safety; on this rude stalk the flower at last of universal peace.

By .JOHN C. KIMBAI...

26. Evolution of the Mechunic Ais. Development of the human hand; the earliest use of implements and tools; man's mechanical strncture and adaptation for work; the psychology of the mechanic arts; the relation of mechanies to mental evolution; the grenesis of invention; patents and patentlaws; inventions in agriculture ani manufactures; have they benefiter the laboring classes?

By JAmEs A. SKIIToN, author of "Tlie Evolution of Society."

27. Evolution of the I'uges System. The definition of wages; ecomomic characteristies of the wages system; wages the ontgrowth of slavery; origin and development of the wages system; its relation to material injorovement, social freedom, and a progressive civilization; to the welfare and progress of the laboring classes; the factory system; importance of stipulated incomes; the wages system compared with Nationalism and Socialism; its relation to social reform.

By Prof. Gromge Gunton, anthor of "Wealth and Progress," "Principles of Social Economics," "Economic Heresies of Henry George," etc.

28. Eduration as a Factor in Ciriliantion. The beginnings of edncation; early methods in Egylut, Persia, China, Greece and Rome; eary Cliristian idleas of education; Catholic and Protestant views; the common-school system; influence of Comenius, Pestalozzi and Froebel; the kindergarten; nannal training; edncation and crime; the university; classical and scientific studies; the higher education of women; co-education; the future of our erlucational system.

By Miss Ca hoidne B. Ia ROW. 


\section{Modern Science Essayist -..Catalogue Continued.}

"No one who wishes to consider the philosophy of evolution can well afford to be without this series of papers."-Christian liegister.

29. Evolution and Sucial Reform: I. The Theological Method. Religion the formative principle of social growth; its relation to Socialism; theological morality ; influence of Christianity on social development ; New 'Testament ideas of marriage and wealth; early Christian Socialism; mnnasticism; influence of the Jews and Mohammedans; the church and industrialisn ; usury or interest; the church and slavery; alms-giving and pauperism; the effect of preaching on character; repentance, conversion and atonement; the religious method the method of personal character.

By REv. Jorn IV. CHADWICK. authol of "Evolution as Related to Religious Thought," "Charles Robert Darwin," etc.

30. Evolution and Social Reform: II. The Socialistic Method. Communism, Socialism and Nationalism; the methorls defined; origin of their modern phases; tendencies of Socialism to militantism; State-Socialism; the doctrine of equality of earnings; equality 7 's. liberty ; Mr. Bellamy's theory criticized; Henry George and the "single-tax"; the injustice of land-confiscation; relation of land-values to the value of improvements; socialistic schemes artificial, not organic; profit-sharing and voluntary co-operation; opportunisu.

By Willian POTTs, author of "Evolution of Vegetal Life."

31. Evolution and Social Reform: III. The Anarchistis Method. Anarchy regarded as a science; its opposition to government by physical force; its methods not revolutionary but evolutionary; anarchisu in social customs; its economic principles; involuntary poverty, its causes and cure; injustice of rent, interest and profits; social parasites: anarchism and the ballot; its method that of education and peaceful propagandism; its ideal that of mutualism between free individuals.

By Hugh (). Pext fcost, editor of '? The Twentieth Century.

32. Enolution and Sorial Reform: IV. Tho Scientific Methor.

The scientific method hased on the uniformity of Nature; the polarity of Individnalism and Socialism; the psychological argument; necessity for govermmental limitation; the scientific method as distinguished from the theological, the socialistic and the anarchistic; it arrocates the golden mean; it cultivates individual independence; its relation to cducation and ethical culture.

By Daniel Greenleaf Thosipson, author" of "A system of Psychol"ogy," "The Problem of Evil," "Herhert Spencer," etc.

33. Asa Gro!l: His Life and Work. His birth and youth; his indebtedness to Amns Eaton; his relations with Dr. John Torrey; his works on lotany; the "North American Flora"; his contributions to the doctrine of Evolution; his correspondence with Darwin; his personal characteristics; his genius recognized by other botanists; his great industry; his unoltrusive modesty; cantes of his unfinished work.

By Mis. MakY Treat, author of "Home Studies in Nature," "My Garden Pets," "Through a Microscope," etc.

34. Edword Livingston Youmans: The Man and His Work.

His birth and ancestry; his education; his early interest in natural science; his blindness; his interest in reforms; his contributions to chemistry ; his career as a scientific lecturer; his acceptance of the doctrine of Evolution; his introduction of Herbert Spencer to America; his establishment of the "International Scientific Series" and the Popmlar. Science Wonthly; his visits to England; his loroad, democratic spirit and unselfish personal character.

By Prof. John Fiske, author of "Cosmic Philosophy," etc.

EACH NUMBER, TEN CENTS.

(Twelve postpaid for $\$ 1.00$.)

*** $\Lambda$ ny of the above sent postpaid on receipt of price. Address, JAMES H. WEST, publisher, 196 Summer Street, Bostox. 


\section{"The Nerd Ideal" Monthly.}

"Full of interest. . . . Tine New IdeaL is an able, bold, honest, progressive Magazine." - Brooklyn Standard-Union.

"As a Magazine The New Inear ranks among the best, able writers giving their views upon living questions." - Lewiston Journal.

"It will find a host of readers, both in the evangelistic and rationalistic world."-New Bedford Standard.

"The New IDEAL seems to have become firmly established. Its contributors are representative of almost every important department of progressive thought."-Brooklyn Times.

"Every page emphasizes the broad and scholarly method that guides the conduct of the Magazine."-Boston Times.

"Excellent contents, in which leading writers intelligently discuss many topics engrossing public thought." - Lowell Vox Populi.

"Able contributions. . . This Magazine ought to be found on the table of every educated, thinking man."-Ottawa Tribune.

"Entertaining not only for the wide range of topies discussed, but for the original views of some of the writers." -Wilmington (N. C.) Star.

"Contains very interesting and instructive articles, that eannot fail to awaken new trains of thought." - St. John Globe.

"People having a tendency toward liberalism in religion-from cautious revisers of the Westminster Confession to downriglrt radicals will take delight in THE NEW IDEAL, - devoted to rational religion, not in a blatant, dogmatic way, but reverently and thoughtfully. Particularly well-written articles."-Buffalo Express.

"Its whole make-up is in good taste, and its thought is excellent in its refreshing vitality."-Opinion-Outlook.

"TInE New InEAL presents a solid and attractive appearance, which is well borne out by the nature of its contents. . . An able list of writers."-Boston Commonwealth.

"THE New IDeal is bold, outspoken and earnest. It holds a religious point of view very different from our own, but we commend the apparent honesty of its search after truth." - Congregationalist.

"This earnest and high-minded publication ... offers substantial food for its readers." - Literary World.

"THE New InEAL ranks high, and its editorials, in prose or in verse, are rich in meat and merit. But the periodical must not expect a multitude at onee. The thick end of the wedge does never lead the way. Who would be with the crowd must be content to follow, and not aspire to lead. From Paganism, to Papalism, to Protestantism, and to Liberalism, is a diminishing order as to numbers, an increasing order as to excellence."-Rev. Perry Marshall, Hartford, Conn.

"The paper is one that should have the hearty support of all liberal mincled men and women. Too much cannot be said in favor of it, devoted as it is [socially] to the interests of humanity and [religiously] to the infusion of new and common sense ideas."

\section{JAMES H. WEST, Publisher,}

196 Summer Street, Boston. 


\section{JAMES H. WEST, Publisher, Boston.}

The Moral and Religious Aspects of Herbert Spencer's Philosophy. By Srurar Drer. Pamplilet, 10 cents.

"An able popular interpreter of the evolution philosophy."

Scientific Theism. By Fraycis E. Aввотt, Pl.D. Cloth, 242 pages, $\$ 2.00$.

"Dr. F. E. Abbot's new book, 'Scientific Theism,' confirms the opinion of the few best able to judge, that he is the ablest philosophical thinker in America, and that his work seems to be the foundation of that deeper religion of the future, sture to come, which will satisfy both the head and the heart of man."-Mr. E. B. Haskell, in Boston Sundai Hercld.

The Philosophy of Free Religion. By Fraxcis E. Аввот, Ph.D.

A series of Nine Papers printed in THE NEW IDEAL. The series mailen, postpaid, for $\$ 1.00$.

The Evolution of Immortality. Suggestions of an Individual Immortality, based upon our Organic and Life History. By C. T. STOCKWELL. Cloth, $12 \mathrm{mo}$, gilt top, uncut edges, 69 pages, \$1.00. "One of the most suggestive and best developed essars on personal immortality which later years have produced." - Literary Woild.

Science and Immortality. Cloth, 7\%) cents ; paper, 50 cents.

A "Symposium," giving the opinion of many of the nost prominent scientific men in this country, concerning the relation of science to the question of immortality. Concise, candid, the earnest thought of the foremost thinkers of the day, whether of expectation or of doubt.

The Morals of Evolution. By M. J. SAvAGE. 191 pages, \$1.00.

Treats such topics as The Origin of Foodness, The Nature of Goodness, The Sense of Obligation, The Relativity of Duty, Morality and Religion in the Future, etc, etc. "We all owe Mr. Savage thanks for the earnestness, frankness, and ability with which he has here illustrated the modern scientific methods of dealing with history, philosophy, and morality." "The book is a fund of intellectrial and moral cheer."

Evolution: A Summary of Evidence. By Capt. RobT. C. ADAsrs, Author of "Travels in Faith from Tradition to Reason." Pampliet, 44 pages, 25 cents.

"An admirable presentation and summing up of the Erolution Argument."

A Study of Primitive Christianity. By LEwIS G. JAxEs. 319 pages, $\$ 1.50$.

Treats of the natural evolution of the Christian Religion, according to the historical methorl, applying the assured results of morlern criticisin to the question of the historical verity of Jesus, the investigation of his life and teaching, and the development of organized Christianity.

Uplifts of Heart and Will. A Series of Religious Meditations, or Aspirations. Addressed to earnest Men and Women. By JAsws H. WEst. Cloth, square 18mo., beveled edges. Price, postpaid, 50 cents. (In paper covers, 30 cts.)

"On purely rational grounds it is not easy to meet the position [of this little book], except by saying that the worls and forms of our [usual] devotion inust be accepted as fronkly symbolic, and not amenable to the understumling.*** It is good to welcome a religions science better than the old hard bigotry. Still, while we by no means accept these ' ' an aderuate substitute for the customary exercises of devotion, they are at least better fitted than the ordinary practice to a state of mind far from uncommon, and greatly deserving of respect."-From a seven-page notice in the Unitarian Review.

The Duties of Women. By Frances Power Cobbe. Cloth, $\$ 1.00$.

"The profoundest, wisest, purest, noblest book in principle, aim and tone yet written upon the true position of woman in socict!y." 
Monthly, \$2.00 per year. Single Number, 20 cents.

\section{Social Science and a Rational Religion. THE NEW IDEAL.}

\section{Some Important Articles that have appeared During 1859.}

MI. J. SAVAGE, Religious Instruction and the Public Schools; "The People" (Poeni); The Coming Civilization.

O. B. FROTHINGHAM, The Need of the Hour; Theory and Conduct; A Word about Agnosticism; History of the Free Religious Association; The F. R.A. and Social Reform.

EDW ARD BELLAMY, Nationalism.

LAURLNCE GRONLUND, Prescriptions for Social Ills ; Freedom or Liberty; An End to Enforced Idleness; Socialism True and False.

REY. DR. MCGLINN, Catholicism and the Public Schools.

COL. T. W. HIGGINSON, Addresses at Convention of the Free Religious Assoeiation, The Earth for Man, etc.

WII. LLOYD GARRISON, Individualism.

EDWIN D. MEAD, The Function of the State.

REY. W. D. P. BLISS, Christian Socialism.

REV. N. P'. GILMAN, Profit-Sharing.

FREDERIC A. HINCKLEY, The First and Great Commandment; The Commonwealth of Man.

WM. J. POTTER, The New Ideal in Religion; Letter to the Free Religious Convention: What the F. R.A. might Do.

B. F. TNDER WOOD, Social Conditions and Tendencies.

F. E. ABBOT, PH.D., Creative Liberalism; The Dependence of Ethics; series of nine papers on The Philosophy of Free Rehgion.

F. H. HOLLAND, Robert Elsmere; The Exile (Song); Lucifer's Umbrella (A Fantasy, in Three Parts); Who Condemmed Jesus to veath; Justice and Taxes; A Monument to all Religions; Ring in the Christ that is to be; How to lessen Poverty (in Two Parts).

GEO. H. HADLEY, Science the Best Teacher of Liberalism; What does Liberalism offer the Workingman? A Socialistic Object-Lesson; Industrial Training as a Remedy.

DR. EDMUND MONTGONERY, Has Morality an Evolutional or an Eternal Basis? Supernatural Ethics Irrational and Immoral: Fatalistic Science and Human Self-Determination; Nationalism or Individualism? The Naturalistic Foundations of Nationalism.

DR. LEWIS G. JANES, The Ideal Liberal Church; The Evolution of the Earth ; A Brotherhood of Consent.

DR. C. T. STOCKWELL, What Shall Liberals do with their Children? The Top of the Coach.

A. N. ADAMS, Agnosticism and Religion; A Study of Religion and seience; Reason and Religion.

REV.PERRY MARSHALL, "Pure Religion" ; The Evolution of Religion; The Fundamentals ; Reform in Worship.

MI. EMILY ADAMS, Children's Sundays ; Hospitals not Creations of Christianity.

ELLEN M. MITCHELL, The Freedom of Fate.

CHAS. D. B. MILLS, whether a New Religion or Not.

C. 13. HOFFMAN, Integral Co-operation in Mexico.

STARR H. NICHOLS, The Materialistic Theory of Society.

HORACE L. TRAUBEL, For the I'arty's Sake; Solution (Poem); Notes on the Recent Ethical Convention; Brave art Thou in Another's Speech (Poem); Sweet Prattling Child (P'oem); Winds of Snows (I'oem).

('HA.' K. WHIPPLE, 'Testimony the Basis of History; Intellectnal Dishonesty; "The Bible Says."

CAI'T. R. C. ADA IIS, Something Better.

GEORGE W. BUCKLEY, Polities and Morals.

ELIZABETH B. CHACE, Woman and Current Reforms.

B. W. BALL. Romanism and American Liberty; The Future American Citizen.

MRS. B. F. UNDERWOOD, The I'hilosophie Spirit vs. Egotism.

IIRS. CLARA II. BISBEE, Freethought and Ethics.

ELISSA M. MOORE, A Vision Past and Future; Women and Science; Light (Poem); Intellectual Freedom.

Address The New IDeaL,

Estes Press Building, 192 Summer st., Boston, Mass. 





\section{4. . "

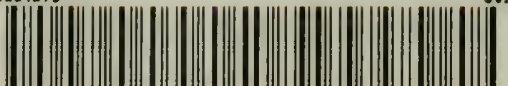 \\ 3 5002003755480 \\ Brooklyn Ethical Association.}

Evolution.

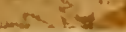

\section{Date Due}

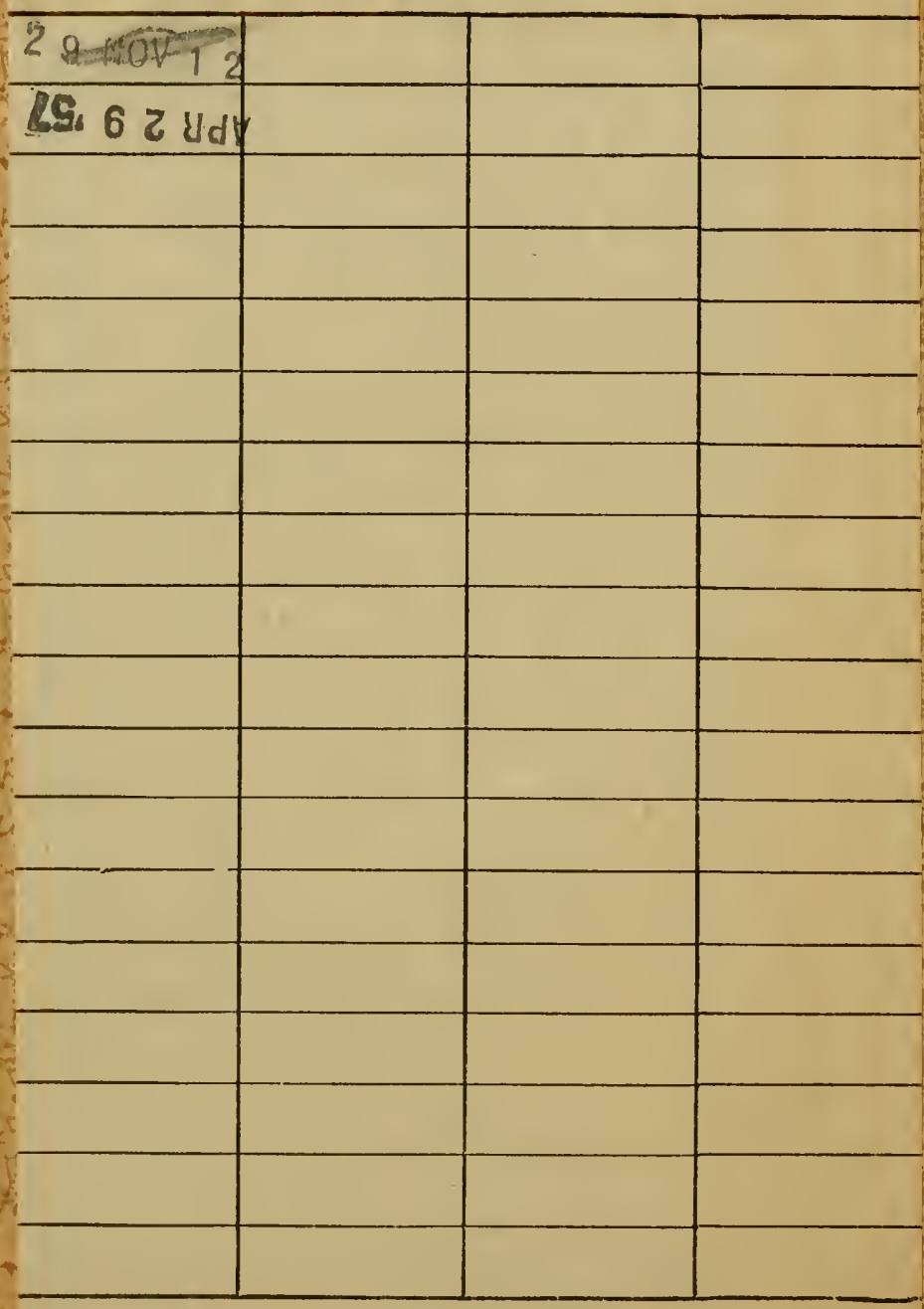

L. B. Cat. No. I 137
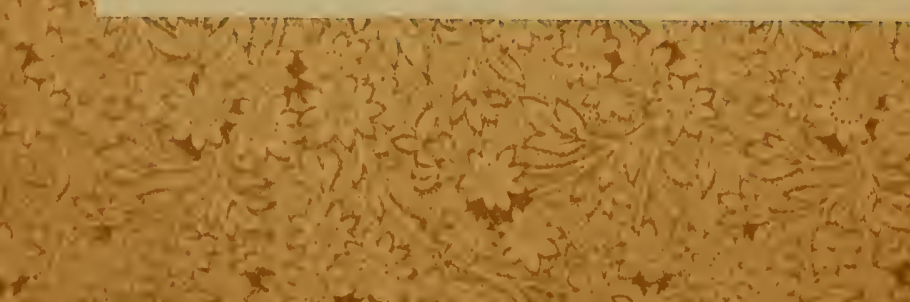
B

$$
\begin{array}{ll}
818 & 39544
\end{array}
$$

BYTHOR

$$
\text { EVOlution }
$$

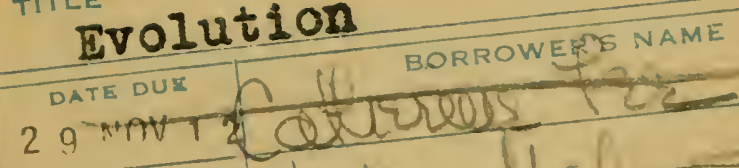

$$
\text { APR } 29157
$$$$
\text { B }
$$$$
818
$$$$
\text { B75 }
$$

200LOGY LIGAMY

$$
39544
$$


